TALITA DE FREITAS ALVES

ANÁLISE DO COMPORTAMENTO DE VIA PERMANENTE LASTRADA COM EMPREGO DE SUBLASTRO BETUMINOSO

São Paulo

2018 
TALITA DE FREITAS ALVES

\section{ANÁLISE DO COMPORTAMENTO DE VIA PERMANENTE LASTRADA COM EMPREGO DE SUBLASTRO BETUMINOSO}

Dissertação apresentada à Escola Politécnica da Universidade de São Paulo para obtenção do título de Mestre em Ciências.

São Paulo 2018 
TALITA DE FREITAS ALVES

\section{ANÁLISE DO COMPORTAMENTO DE VIA PERMANENTE LASTRADA COM EMPREGO DE SUBLASTRO BETUMINOSO}

Dissertação apresentada à Escola Politécnica da Universidade de São Paulo para obtenção do título de Mestre em Ciências.

Área de concentração:

Engenharia de Transportes

Orientador:

Profa. Dra. Rosângela dos Santos Motta

\section{São Paulo}

2018 
Este exemplar foi revisado e corrigido em relação à versão original, sob responsabilidade única do autor e com a anuência de seu orientador.

São Paulo, de de

Assinatura do autor:

Assinatura do orientador:

Catalogação-na-publicação

Alves, Talita de Freitas

Análise do comportamento de via permanente lastrada com emprego de sublastro betuminoso / T. F. Alves -- versão corr. -- São Paulo, 2018.

$148 \mathrm{p}$.

Dissertação (Mestrado) - Escola Politécnica da Universidade de São Paulo. Departamento de Engenharia de Transportes.

1.Ferrovias \{Infraestrutura\} 2.Mistura asfáltica 3.Monitoramento I.Universidade de São Paulo. Escola Politécnica. Departamento de Engenharia de Transportes II.t. 
À minha fonte inesgotável de amor e de felicidade:

Carlos, Silvia, Carla e Kilvia. 


\section{AGRADECIMENTOS}

À Deus, pelo dom da vida e pelas graças constantes na minha caminhada. A Ti, Senhor, todo louvor e adoração.

Aos meus pais, Carlos e Silvia, por serem minha maior referência de amor, humanidade e fortaleza. Cada etapa vencida é fruto das sementes plantadas e primorosamente cultivadas por vocês! "A palavra convence, mas o exemplo arrasta".

Aos meus outros dois terços, Carla e Kilvia, significado mais forte e sincero da palavra irmandade. Obrigada por sonharem junto comigo e serem, ao mesmo tempo, torcida e inspiração.

Aos docentes, quais ensinamentos transmitidos transpassaram os muros das escolas e universidades e abriram minha visão para o mundo. O meu muito obrigada, em especial, às mulheres inspiradoras e profissionais inigualáveis da área de pavimentação: Profa. Dra. Rosângela Motta, pela confiança, carinho e orientação neste período de crescimento e autoconhecimento; à Profa. Dra. Liedi Bernucci, à Profa. Dra. Kamilla Vasconcelos e à Profa. Dra. Suelly Barroso, pelas orientações extraoficiais e contribuições significativas na jornada acadêmica e pessoal.

Aos que são igualmente autores deste trabalho tamanho o empenho, apreço e colaboração para com o seu desenvolvimento: Edson de Moura, José João Pires, Paulo Moraes e Larissa Zipoli. Tão importante quanto todo o conhecimento adquirido foram as lições de cooperação, paciência, humildade e profissionalismo aprendidas com vocês. Sinto-me lisonjeada em tê-los tido ao meu lado nesta caminhada!

Aos amigos de curso e parceria certa em qualquer empreitada: André, Antonio, Armando, Camila, Deise, Domênico, Fernanda, Guilherme, Ingrid, luri, Jean, Jennifer, João Paulo, Kazuo, Laura, Lucas, Manuela (Eric e Alice), Márcia, Matheus e Zila. Com votos de que os laços de amizade aqui atados se fortaleçam mesmo com a término da pesquisa. 
À equipe LTP-EPUSP, sinônimo de excelência, cooperação e acolhimento: Diomária, Robson, Vanderlei, Erasmo e Higor.

Ao Laboratório de Mecânica dos Solos da EPUSP, pela disponibilidade de auxílio e equipamentos sempre que necessário.

À empresa MRS Logística S.A., representada pelos engenheiros Ronaldo Nogueira e Herbert Felipe. O desenvolvimento da ciência é resultado do esforço conjunto do público e do privado, em prol do beneficiamento da sociedade como um todo. Muito obrigada pelo reconhecimento da necessidade de se investir em novas tecnologias, pelo suporte e pela colaboração em todos os aspectos relativos à execução e acompanhamento dos trechos experimentais.

Ao IFSTTAR, representado pelo pesquisador Thomas Gabet e pelo doutorando Octavio Lopez-Polanco, pelo recebimento afetuoso e ensinamentos repassados.

Ao Conselho Nacional de Desenvolvimento Científico e Tecnológico (CNPq) e à Fundação para o Desenvolvimento Tecnológico da Engenharia (FDTE), pela concessão de bolsas de fomento à pesquisa.

Aos familiares e amigos que se fizeram presentes das mais variadas formas e compreenderam minha ausência quando necessária. Muito obrigada! 
No fundo, todos temos necessidade de dizer quem somos e o que é que estamos a fazer e a necessidade de deixar algo feito, porque esta vida não é eterna e deixar coisas feitas pode ser uma forma de eternidade.

(José Saramago) 


\section{RESUMO}

Ao longo de sua vida útil, com o acúmulo de tráfego e de solicitações ambientais, infraestruturas de transportes degradam-se em termos de desgaste dos seus componentes e deformações permanentes de suas camadas, acarretando na perda gradual da qualidade estrutural e funcional da via. A camada de sublastro, parte integrante da subestrutura ferroviária, possui contribuição significativa no comportamento mecânico global de uma via permanente. Suas principais funções estão relacionadas à drenagem, atenuação e distribuição de tensões, e separação e transição entre as camadas de lastro e subleito. O objetivo principal deste estudo foi comparar duas diferentes configurações de sublastro implementadas em uma ferrovia de carga brasileira através da medição de respostas mecânicas e parâmetros geométricos "in situ". O emprego de sublastro betuminoso constituiu-se como a primeira aplicação de campo deste tipo no País e ambas as seções foram monitoradas também por intermédio de sensores de temperatura e de tensão. Procedeu-se a caracterização física e mecânica dos materiais que compõem os trechos analisados em laboratório. Ademais, tensões de sucção foram medidas em diferentes locais e profundidades da camada de subleito, a fim de verificar a eficácia da camada betuminosa em impermeabilizar as camadas subjacentes. Os resultados mostraram uma eficiência global superior do trecho contendo sublastro betuminoso comparativamente à seção de referência (sublastro granular). Variações das tensões de sucção ao longo de duas estações climáticas mostraram que a mistura asfáltica protegeu satisfatoriamente o subleito quanto à infiltração de água oriunda das precipitações. Medidas de temperatura tomadas em diferentes pontos das camadas de sublastro mostraram que a mistura asfáltica se encontra protegida das variações térmicas e da incidência de radiação solar, uma vez que está isolada pela camada de lastro. Em termos de deslocamentos medidos com o equipamento DMD (Dispositivo para Medição de Deslocamentos), mostrou-se uma redução crescente no deslocamento vertical médio da seção com sublastro betuminoso em comparação com a seção com sublastro granular. Por consequência, o módulo de via, $u$, calculado para ambas as seções, revelou que o perfil contendo mistura asfáltica tende a defletir menos quando solicitado pela passagem de trens. Medidas de parâmetros 
geométricos utilizando o equipamento Trolley AMBER apontaram uma relação bidirecional entre o comportamento mecânico e a qualidade da geometria da via, observada antes e após intervenção mecanizada de socaria.

Palavras-chave: Ferrovias \{lnfraestrutura\}, Mistura asfáltica, Monitoramento 


\begin{abstract}
In the course of its service life, with traffic loading accumulation in addition to environmental effects, transportation infrastructures tend to degrade in terms of wear of their components and permanent deformation of their layers, resulting in the gradual loss of structural and functional quality of the railway. The subballast plays an important role as part of the railway substructure and it has a significant contribution to the overall mechanical behavior of the track. Its main functions are related to drainage, to load attenuation and distribution, and to the separation and transition between the ballast and the subgrade. The main objective of this study was to compare two different subballast configurations implemented in a freight railway profile in Brazil through measurements of mechanical and geometric parameters in field. The use of bituminous subballast was the first application of this type in the country and both sections were also monitored by means of temperature and pressure sensors. Laboratory tests for physical and mechanical characterization for all materials composing both experimental sections were performed. In addition, the water pressure in terms of suction were measured at different places and depths of the subgrade, in order to verify the effectiveness of the bituminous subballast in waterproofing the underlying layers. The results showed a superior overall efficiency of the section containing bituminous subballast compared to the reference section (granular subballast). The suction tension variation measured along two climatic seasons showed that the asphalt mixture satisfactorily protects the subgrade from the infiltration of water due precipitations. Temperature measurements taken at different points of the subballast layers showed that the asphalt mixture is protected from thermal and solar radiation peaks, since it is isolated by the ballast layer from atmospheric environmental effects. In terms of displacements acquired using the DMD (Displacement Measurement Device) it was observed an increasing reduction in the mean vertical displacement of the section with bituminous subballast compared to the section with granular subballast. Consequently, the track modulus, $u$, calculated for both sections revealed that the profile containing asphalt mixture tends to deflect less when requested by the train passage. Measurements of geometric parameters made with the Trolley AMBER device highlighted the bidirectional relationship between the
\end{abstract}


mechanical behavior and the quality of the track geometry, observed before and after tamping procedure.

Keywords: Railways \{Infrastructure\}, Asphalt mixtures, Monitoring 


\section{LISTA DE ILUSTRAÇÕES}

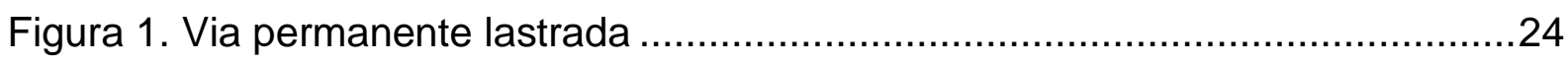

Figura 2. Esquema de forças aplicadas pela passagem da roda nos trilhos.............29

Figura 3. Distribuição de cargas na via permanente ..............................................31

Figura 4. Parâmetros geométricos de via permanente.............................................34

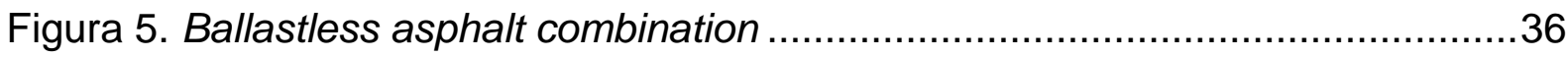

Figura 6. (a) Asphalt combination e (b) Asphalt underlayment................................36

Figura 7. Seções experimentais italianas (linha Direttissima) .................................38

Figura 8. Corte transversal - Pavimento ferroviário italiano com sublastro betuminoso

Figura 9. Seção transversal típica francesa antes e depois da inserção da camada betuminosa. 40

Figura 10. Aplicação em cruzamento: (a) retirada da grade e (b) compactação da

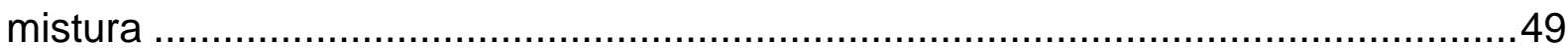

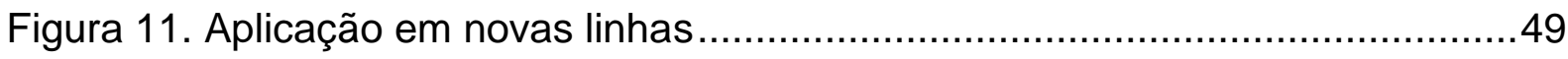

Figura 12. Redução das pressões medidas no topo das camadas ........................52

Figura 13. Representação esquemática da economia de material de lastro ..............53

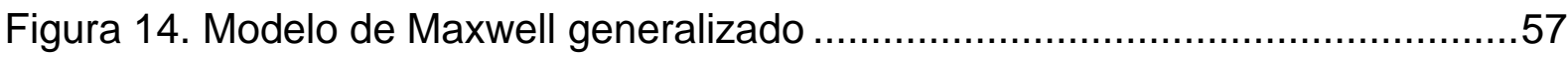

Figura 15. Representação gráfica da função de relaxação ……….........................57

Figura 16. Modelo de Kevin-Voigt generalizado ..................................................58

Figura 17. Representação gráfica da função de fluência .......................................58

Figura 18. Solicitação senoidal e ângulo de fase dos materiais viscoelásticos .........59

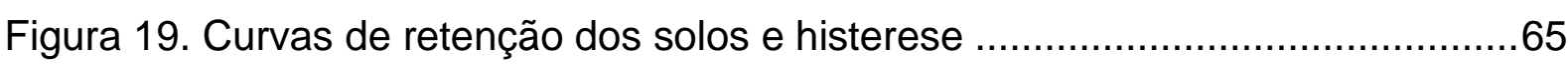

Figura 20. Fluxograma de atividades de avaliação ............................................68

Figura 21. Malha ferroviária sob gestão da MRS Logística S.A. .............................69

Figura 22. Localização do trecho experimental ..................................................

Figura 23. (a) Cava de inspeção do pavimento ferroviário e (b) Detalhe do lastro

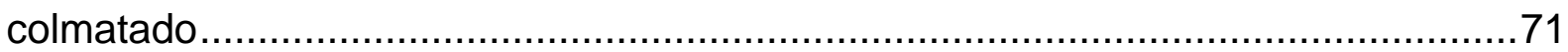

Figura 24. Ensaio de DCP e LWD no km 20 + 600 da linha 2 PG-RS ...................72

Figura 25. Distribuição granulométrica dos agregados para sublastro betuminoso ..73

Figura 26. Distribuição granulométrica de agregados para sublastro granular .........74 
Figura 27. Seções de projeto dos trechos experimentais (fora de escala)...... .75

Figura 28. (a) Corte dos trilhos e (b) Retirada de dormentes ..................................76

Figura 29. Corte da subestrutura para implantação de sublastro betuminoso ...........77

Figura 30. Execução da primeira camada de mistura asfáltica ................................78

Figura 31. (a) Despejo da primeira camada de lastro e (b) Disposição de dormentes

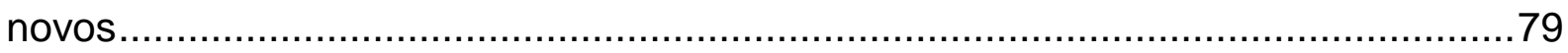

Figura 32. Célula de pressão total de $200 \mathrm{kPa}$ e detalhe da sua colocação no trecho com sublastro betuminoso.

Figura 33. Corte transversal com posicionamento das células de pressão (fora de escala).

Figura 34. Termopar e detalhe da sua colocação no trecho com sublastro betuminoso

Figura 35. Corte transversal com posicionamento dos termopares (fora de escala). 82 Figura 36. (a) Sensores de sucção em processo de saturação, (b) Detalhe da sua instalação no trecho e (c) Dispositivo para aquisição de dados .83 Figura 37. Corte transversal com posicionamento dos sensores de sucção (fora de escala).

Figura 38. Dispositivo para Medição de Deslocamentos e detalhe do LVDT no patim do trilho

Figura 39. Detalhes em planta e perfil do Dispositivo para Medição de Deslocamentos

Figura 40. Trolley AMBER em operação na via e gravador manual de geometria....86

Figura 41. Gráfico para classificação de solos tropicais. .88

Figura 42. Carta de Classificação do Método das Pastilhas .89

Figura 43. Esquema do aparato utilizado no ensaio da placa de sucção (fora de escala) 90

Figura 44. Placa de pressão.

Figura 45. Representação gráfica dos valores obtidos pelo ensaio de DCP...... .95

Figura 46. Verificação de espessura de lastro no trecho com sublastro granular .....97 Figura 47. Sinal registrado pela célula de pressão inserida na interface dormente / lastro do trecho com sublastro betuminoso .............................................................99

Figura 48. Temperaturas medidas na camada de sublastro betuminoso. 101 
Figura 49. Temperaturas medidas na camada de sublastro granular 101

Figura 50. Temperaturas medidas em sensores de mesma posição em ambas configurações de sublastro.

Figura 51. Posicionamento dos sensores nos trechos com sublastro (a) betuminoso e (b) granular. 104

Figura 52. Tensões de sucção de superfície nos trechos com sublastro (a) betuminoso e (b) granular 104

Figura 53. Tensões de sucção de profundidade nos trechos com sublastro (a) betuminoso e (b) granular

Figura 54. Análise das tensões de sucção medidas nos sensores de (a) superfície e (b) profundidade 106

Figura 55. Sinal de deslocamento registrado na seção com sublastro betuminoso 108

Figura 56. Deslocamentos médios por acúmulo de tráfego 109

Figura 57. Módulo de via, $u$, por acúmulo de tráfego 111

Figura 58. Análise das medidas de bitola 112

Figura 59. Análise das medidas de inclinação 113

Figura 60. Análise das medidas de empeno (10 m) 115

Figura 61. Representação gráfica das medidas de inclinação nos trechos contendo (a) sub. betuminoso, (b) sub. granular e sem intervenção 115

Figura 62. Curva granulométrica do solo do subleito 117

Figura 63. Módulo de resiliência do solo do subleito 119

Figura 64. Curva de retenção do solo: teor de umidade volumétrico em função da sucção 120

Figura 65. Curva de retenção do solo: teor de umidade gravimétrico em função da sucção. 121

Figura 66. Curva de retenção do solo: grau de saturação em função da sucção ...121

Figura 67. Ajuste da curva de retenção: CP 1, w ótimo 122

Figura 68. Ajuste da curva de retenção: CP 2, w ótimo $+2 \%$ 123

Figura 69. Ajuste da curva de retenção: CP 3 , w ótimo - 2\% 123

Figura 70. Curva granulométrica do sublastro granular 124

Figura 71. Módulo de resiliência do sublastro granular 125

Figura 72. Curva granulométrica do material de lastro 125 
Figura 73. Curva granulométrica dos agregados (mistura asfáltica) 126 


\section{LISTA DE TABELAS}

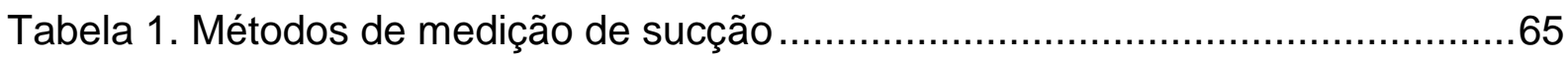

Tabela 2. Tráfego solicitante nas linhas 1 e 2 da via PG-RS no ano de 2017 .........70 Tabela 3. Valores de tensão de compressão medidas no trecho com sublastro granular 100

Tabela 4. Deslocamentos médios medidos com base nas solicitações dinâmicas das locomotivas 108

Tabela 5. Valores de módulo de via, $u$ 111

Tabela 6. Índices de plasticidade e classificação HRB e SUCS do solo 117

Tabela 7. Parâmetros obtidos pelo Método de Identificação Expedita. 118

Tabela 8. Parâmetros M-MCV e classificação MCT 118

Tabela 9. Características de moldagem de corpos de prova miniatura para obtenção da curva de retenção. 120

Tabela 10. Ajuste das curvas de retenção ao modelo de van Genuchten 122

Tabela 11. Resultados dos ensaios de forma do material de lastro 126

Tabela 12. Caracterização física da mistura asfáltica 126 


\section{LISTA DE ABREVIATURAS E SIGLAS}

AASHTO American Association of State Highway and Transportation Officials ABNT Associação Brasileira de Normas Técnicas

AMV Aparelho de Mudança de Via

AREMA American Railway Engineering and Maintenance-of-Way Association

ASTM American Society for Testing and Materials

BGS Brita Graduada Simples

CAP Cimento Asfáltico de Petróleo

CBR California Bearing Ratio

CBUQ Concreto Betuminoso Usinado a Quente

CEMADEN Centro Nacional de Monitoramento e Alertas de Desastres Naturais

$\mathrm{CH} \quad$ Cal Hidratada

DCP Dynamic Cone Penetrometer

DERSA Desenvolvimento Rodoviário S.A.

DMD Dispositivo para Medição de Deslocamentos

DMT Distância Média de Transporte

DNER Departamento Nacional de Estradas e Rodagens

DNIT Departamento Nacional de Infraestrutura de Transportes

EPUSP Escola Politécnica da Universidade de São Paulo

EUA Estados Unidos da América

FWD Falling Weight Deflectometer

GB Grave Bitume

HRB Highway Research Board

IBGE Instituto Brasileiro de Geografia e Estatística

ICDD International Centre for Diffraction Data

ICSD Inorganic Crystal Structure Database

LTP Laboratório de Tecnologia da Pavimentação

LVDT Linear Variable Displacement Transducers 
LWD Falling Weight Deflectometer

MCT Miniatura, Compactado, Tropical

MR Módulo de Resiliência

MTBT Milhões de Toneladas Brutas Transportadas

NBR Norma Brasileira

PG-RS Piaçaguera - Raiz da Serra

SNCF Société Nationale des Chemins de fer Français

SUCS Sistema Unificado de Classificação de Solo 


\section{LISTA DE SÍMBOLOS}

\begin{tabular}{ll}
$p$ & Força por unidade de comprimento \\
$u$ & Módulo de via \\
$y$ & Deflexão da via \\
$E$ & Módulo de elasticidade \\
l & Momento de inércia \\
$\mathrm{P}$ & Carga da roda \\
$e$ & Neperiano \\
$\lambda$ & Fator de amortecimento \\
$\mathrm{M}(\mathrm{x})$ & Momento fletor \\
$y_{0}$ & Deflexão máxima da via \\
$\mathrm{MPa}$ & Megapascal \\
$\mathrm{Km}$ & Quilômetro \\
$\mathrm{mm}$ & Milímetro \\
$\mathrm{cm}$ & Centímetro \\
$\mathrm{m}$ & Metro \\
$\mathrm{GPa}$ & Gigapascal \\
${ }_{\mathrm{O}} \mathrm{C}$ & Celsius \\
$\mathrm{Hz}$ & Hertz \\
$\mathrm{kPa}$ & Kilopascal \\
$\mathrm{h}$ & Hora \\
$\sigma$ & Tensão constante aplicada \\
$\mathrm{E}$ & Constante dos elementos elásticos \\
$\eta$ & Constante dos elementos viscosos \\
$\mathrm{E} 0$ & Parcela de deformação elástica \\
$\tau$ & Tempo de aparição da solicitação \\
$\mathrm{t}$ & Tempo de observação da resposta à solicitação aplicada \\
$\theta$ & Temperatura do material \\
$\varphi$ & Defasagem relativa \\
$\varepsilon(\mathrm{t})$ & Deformação \\
$F$ & Carga vertical \\
$\delta_{\mathrm{r}}$ & Deslocamento elástico ou resiliente \\
$\mathrm{h}$ & Altura do corpo de prova \\
$\mu$ & Coeficiente de Poisson \\
\hline
\end{tabular}




\begin{tabular}{ll}
$\Psi$ & Sucção do solo ou sucção total \\
$\mathrm{R}$ & Constante universal dos gases \\
$\mathrm{T}$ & Temperatura absoluta \\
$v_{w}$ & Volume específico da água \\
$\omega_{v}$ & Massa molecular do vapor de água dos poros \\
$u_{v}$ & Pressão parcial de vapor de água dos poros \\
$u_{v 0}$ & Pressão de saturação do vapor de água \\
$S_{r}$ & Grau de saturação residual \\
$w$ & Teor de umidade gravimétrica \\
$\theta$ & Teor de umidade volumétrico \\
$e$ & Índice de vazios \\
$n$ & Porosidade \\
$\gamma_{d}$ & Peso específico seco \\
$\gamma_{w}$ & Peso específico da água \\
$S_{e}$ & Grau de saturação efetivo \\
$S$ & Grau de saturação \\
$\Psi_{b}$ & Sucção na entrada de ar \\
$\lambda$ & Índice de distribuição de poros \\
$\theta_{r}$ & Teor de umidade volumétrico residual \\
$\theta_{s}$ & Teor de umidade volumétrico saturado \\
$\alpha$ & Coeficiente de ajuste \\
$\mathrm{n}$ & Inclinação da curva característica \\
$D_{n}$ & Abertura da malha pela qual passam n\% em massa do material \\
$\mathrm{L}$ & Litro \\
$\mathrm{Vcc}$ & Voltagem em conrrente contínua \\
$\mathrm{mA}$ & Miliampere \\
$\mathrm{C}$ & Coeficiente Mini-MCV \\
$\mathrm{d}$ & Coeficiente Mini-MCV \\
$\mathrm{Pi}$ & Perda de massa por imersão \\
$\mathrm{e}^{\prime}$ & Coeficiente Mini-MCV \\
$\Delta \mathrm{w}$ & Desvio de umidade \\
$\varepsilon$ & Erro \\
$\theta_{i}$ & Teor de umidade volumétrico previsto \\
$\theta_{i}$ & Teor de umidade volumétrico medido \\
$N$ & Número de dados experimentais \\
& \\
\hline &
\end{tabular}




\section{SUMÁRIO}

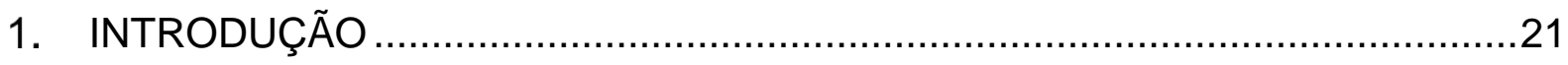

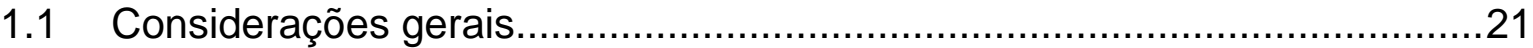

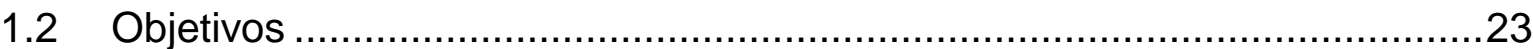

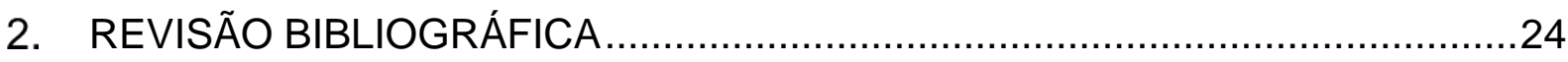

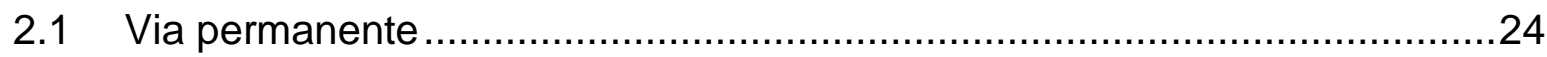

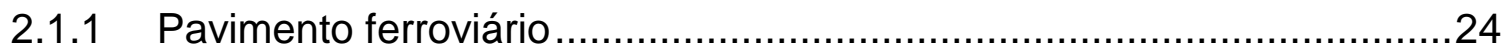

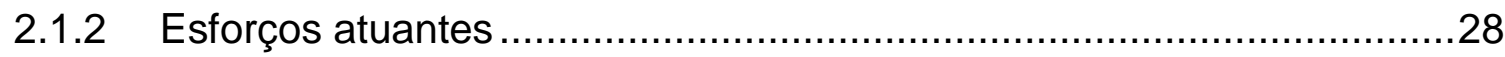

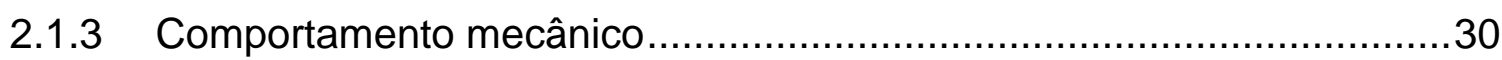

2.1.4 Parâmetros geométricos .................................................................33

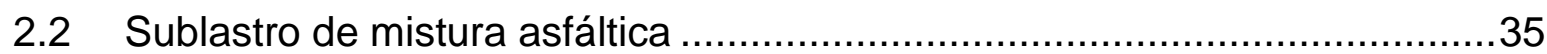

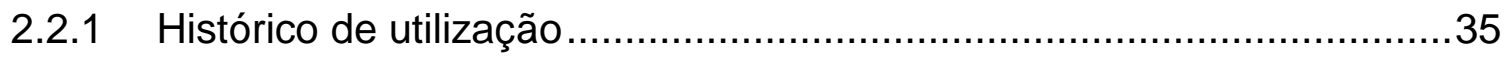

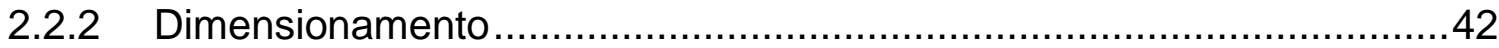

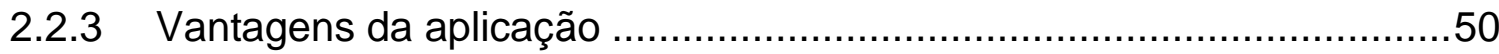

2.3 Fatores influentes no comportamento da via com sublastro betuminoso .....54

2.3.1 Comportamento viscoelástico das misturas asfálticas...........................55

2.3.2 Variação da condição de umidade do subleito .....................................60

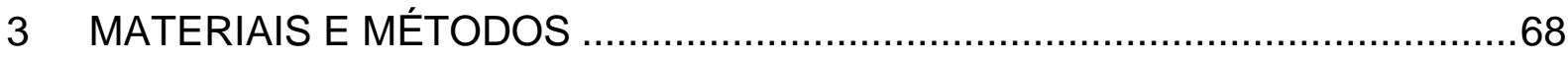

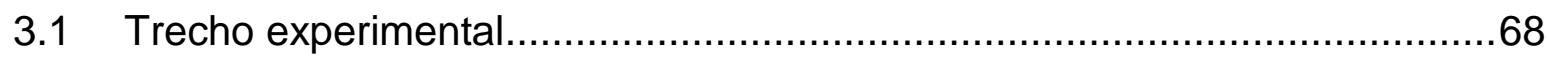

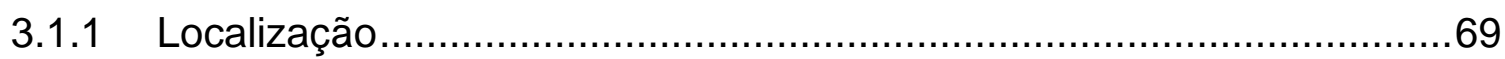

3.1.2 Ensaios preliminares "in situ" .......................................................

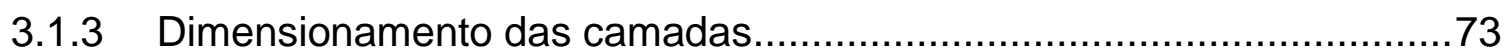

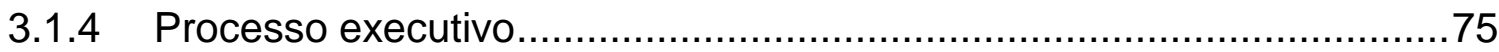

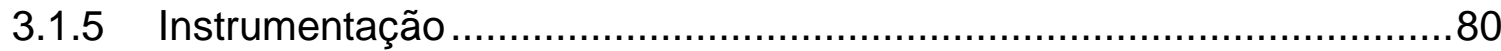

3.1.6 Medidas da resposta mecânica e geométrica da via .............................84 
3.2 Caracterização física e mecânica dos materiais .86

3.2.1 Materiais granulares

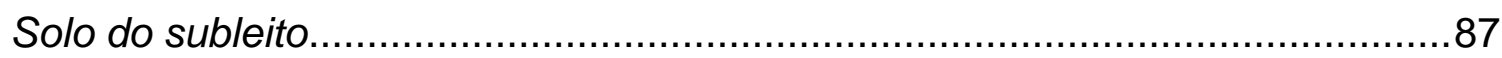

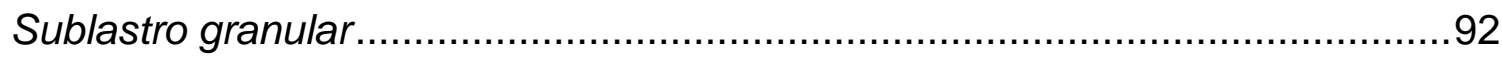

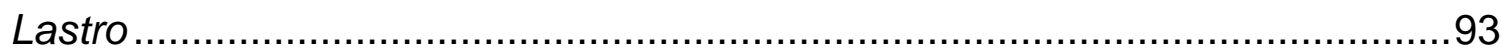

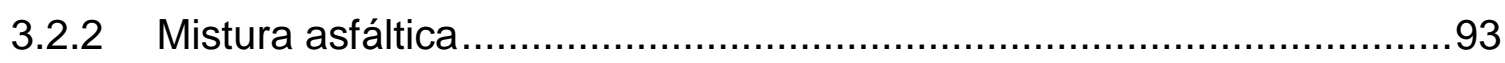

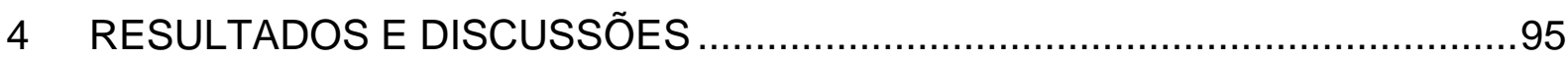

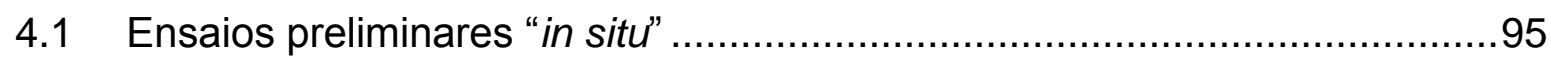

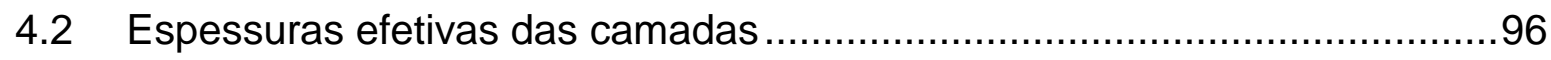

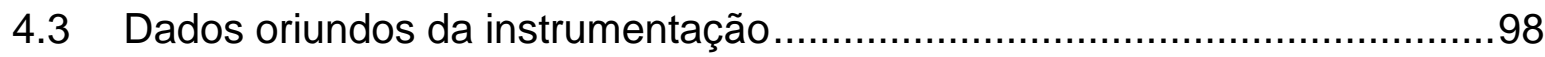

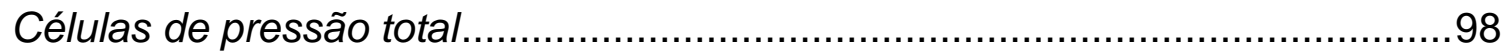

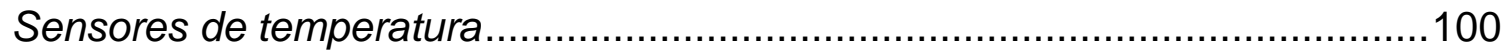

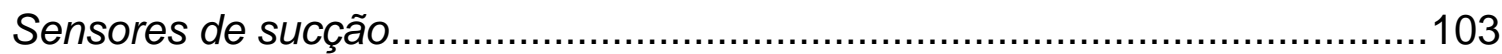

4.4 Dados oriundos das medidas de acompanhamento ...............................107

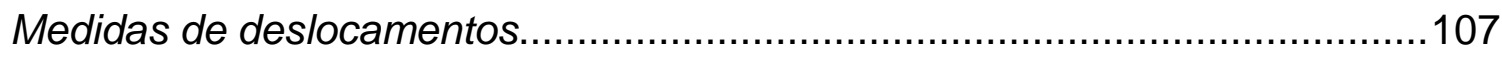

Determinação do módulo de via.................................................................110

Medidas de parâmetros geométricos ......................................................112

4.5 Caracterização física e mecânica dos materiais ......................................116

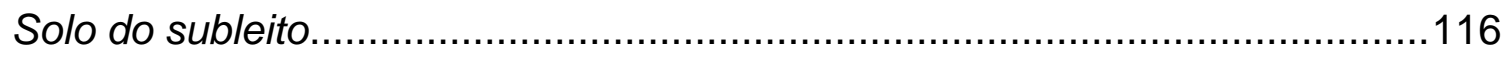

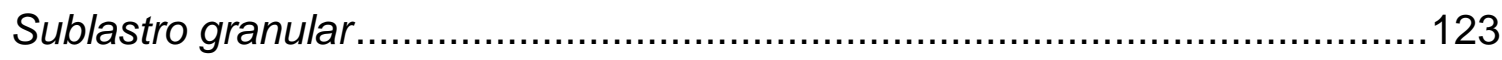

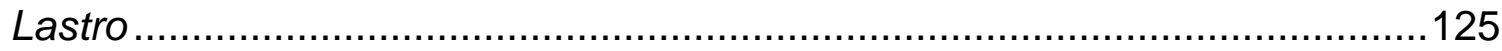

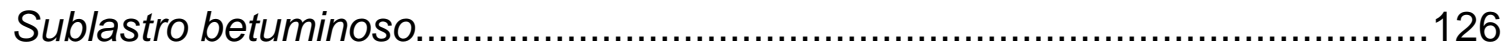

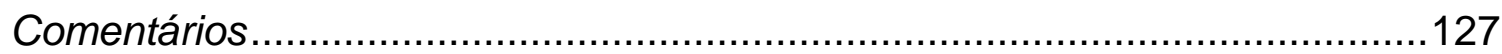

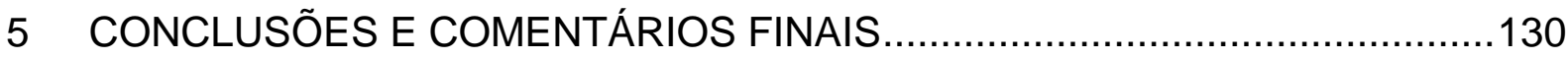

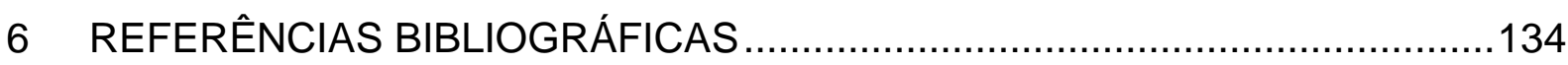

ANEXO A - Dados pluviométricos. .................................................................144 


\section{INTRODUÇÃO}

\subsection{Considerações gerais}

O cenário da logística de transportes no Brasil, ilustrado pelo Instituto Brasileiro de Geografia e Estatística (IBGE) em 2014, confirma a notável predominância do modal rodoviário no transporte de cargas, em contraponto a uma reduzida exploração do potencial dos modais ferroviário e aquaviário para este setor no País. No que concerne à parcela ferroviária, o minério de ferro constitui-se como grande âncora, classificado como produto predominantemente transportado pelas ferrovias brasileiras, seguido por produtos do agronegócio (com destaque para a soja e o milho), aço, carvão, celulose, fertilizantes, bauxita, cimento e contêineres.

A entrada da China na economia de mercado e a repressão de crescimento competitivo brasileiro, por conta de limitações estruturais, têm intensificado a necessidade de se investir em infraestrutura, por meio de recursos advindos de setores públicos e privados, a fim de acelerar o desenvolvimento econômico do País, em caráter emergencial. Melhorias nos sistemas de transporte acarretam na redução de custos logísticos, elevam a competitividade dos produtos nacionais no mercado externo e geram crescimento no mercado interno. No entanto, muitas são as problemáticas que comprometem a eficiência do modal ferroviário no Brasil, constituídas por gargalos físicos, financeiros e institucionais (REVISTA FERROVIÁRIA, 2013).

O estado de São Paulo destaca-se, dentro deste contexto, por possuir infraestrutura de transportes na qual as cidades do interior estão conectadas à capital por uma vasta rede rodoviária. Ademais, comporta o maior aeroporto (Guarulhos) e o porto com maior movimentação de carga do País, o Porto de Santos, que devido à sua posição estratégica é o ponto de escoamento da produção com maior valor agregado que segue para outras regiões brasileiras, bem como para exportação, além de ser local de desembarque mais próximo ao maior centro consumidor nacional (IBGE, 2014). 
Do ponto de vista estrutural, as vias permanentes ferroviárias que se conectam ao Porto de Santos, em sua grande maioria, datam da década de 80, e possuem camada de lastro diretamente assentada em solo de subleito, o que, para o contexto da época, atendia às solicitações com bons resultados. Entretanto, com o aumento do tráfego, das velocidades de operação e/ou dos valores de carga por eixo transportada, estas passaram a implicar em intervenções de manutenção frequentes e cada vez mais onerosas, devendo-se considerar ainda que estas se tratam da parcela mais dispendiosa dos custos totais com infraestrutura ferroviária.

Soluções para a melhoria estrutural de um pavimento ferroviário podem ser divididas em duas categorias: as que intervêm na superestrutura, permitindo a otimização da elasticidade vertical da via, e as que reforçam a capacidade de suporte da subestrutura. Dentre as soluções que intervêm na subestrutura, a inserção de uma camada mais rígida, quando comparada à camada de sublastro granular convencional, e com comportamento resiliente característico dos materiais viscoelásticos, pode reduzir, dentre outros fatores, o nível de tensões que atinge a camada de subleito e os deslocamentos verticais da camada de lastro (TEIXEIRA et al., 2010). Consequentemente, a geometria da via pode ser mantida dentro de parâmetros aceitáveis, não havendo desgaste excessivo de seus componentes, inferindo em uma menor necessidade de manutenções corretivas. Por essa razão, a substituição parcial ou total do sublastro granular por um sublastro betuminoso na construção e manutenção de vias permanentes tem sido uma solução empregada em diversos países, a fim de elevar a capacidade de suporte de suas vias férreas e reduzir a frequência de manutenções destas.

Itália (DI MINO et al., 2015), França (CARDONA et al., 2016) e Japão (ALBANAT et al., 2011) reportam vantagens do emprego desta técnica na construção de suas linhas de alta velocidade para passageiro, enquanto nos Estados Unidos (HUANG et al., 1987; ROSE e BRYSON, 2009; ROSE et al., 2011) esta prática é utilizada com sucesso na renovação de áreas críticas, ou seja, zonas da via permanente que deterioram mais rapidamente devido ao excesso de solicitações, a mudanças na rigidez das camadas da subestrutura e a dificuldades de drenagem desses trechos (entradas e saídas de túneis e pontes, passagens em nível, aparelhos de mudança 
de via e cruzamentos). Recentemente, a Espanha (TEIXEIRA et al. 2010) também tem se destacado por investimentos em pesquisas e construção de trechos experimentais com sublastro betuminoso em suas ferrovias. No Brasil (MOTTA et al., 2014; RANGEL et al., 2015), análises do comportamento estrutural do pavimento ferroviário com emprego de camadas betuminosas têm se reservado a simulações numéricas para dimensionamento de espessuras, sendo necessárias pesquisas que atendam questionamentos referentes à dosagem, processo executivo, resposta mecânica e vida útil dessas misturas.

Em vista disso, o presente trabalho busca avaliar o impacto da utilização de uma camada asfáltica como sublastro na resposta mecânica e geométrica de uma seção de via permanente de carga brasileira, na região da Baixada Santista (São Paulo). Para tal, dois trechos foram renovados e monitorados "in situ", por intermédio de medidas de deslocamento vertical, parâmetros geométricos, gradiente térmico e tensões atuantes nas camadas da subestrutura. O primeiro trecho é constituído por um sublastro de concreto betuminoso usinado a quente e o segundo, tido como referência, contém sublastro granular de brita graduada simples. Estudos laboratoriais das propriedades físicas e mecânicas dos materiais geotécnicos que compõem ambas as configurações de pavimento ferroviário foram realizados, assim como a caracterização do material betuminoso empregado.

\subsection{Objetivos}

O principal objetivo deste estudo é, portanto, analisar comparativamente o comportamento mecânico e geométrico de uma via permanente com duas diferentes configurações de sublastro (betuminoso e granular) ao longo das solicitações ambientais e do acúmulo de carga na mesma. Adicionalmente, objetiva-se detalhar etapas do processo construtivo de renovação de linhas férreas para emprego de sublastro betuminoso e desenvolver estudos ("in situ" e em laboratório) relativos à caracterização física e mecânica dos materiais que compõem as camadas da subestrutura avaliada, a fim de compreender as condições particulares às quais estes se encontram e a influência destas no comportamento global da estrutura de pavimento ferroviário. 


\section{REVISÃO BIBLIOGRÁFICA}

\subsection{Via permanente}

\subsubsection{Pavimento ferroviário}

À luz da Mecânica dos Pavimentos, o pavimento ferroviário constitui-se por um complexo sistema estrutural em camadas que tem como finalidade receber adequadamente as cargas oriundas da passagem dos trens e das solicitações ambientais e transmiti-las de maneira reduzida ao solo de fundação (subleito), de forma segura e econômica (SILVA, 2002). Os componentes da via permanente lastrada (Figura 1), objeto de estudo deste trabalho, podem ser classificados em duas categorias: superestrutura e subestrutura. Na superestrutura estão inclusos os trilhos, os acessórios metálicos de apoio e de fixação, e os dormentes. Na subestrutura estão inclusas as camadas de lastro, sublastro e subleito.

Figura 1. Via permanente lastrada

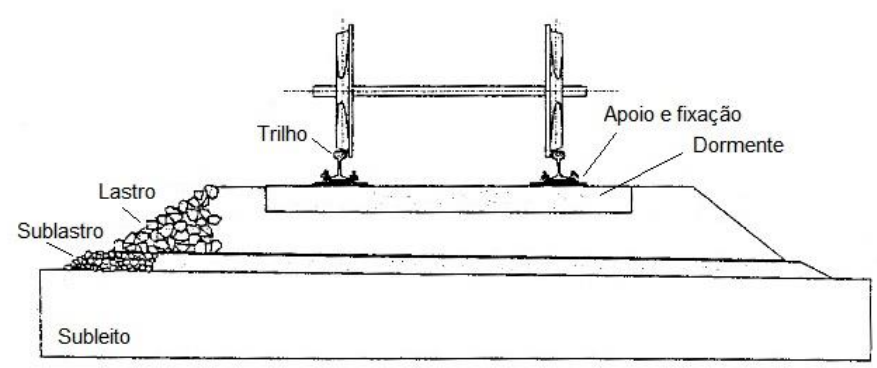

Fonte: adaptado de Esveld, 2001.

Os trilhos são componentes de aço alocados longitudinalmente na via que têm como função guiar as rodas dos trens de maneira uniforme e contínua (SELIG e WATERS, 1994). Devem possuir rigidez suficiente para servir como vigas que transferem as cargas concentradas aplicadas pelas rodas aos dormentes, sem apresentar deflexão excessiva nas seções de espaçamento entre os mesmos; servindo também como condutores elétricos e aterramento para sistemas de locomotivas eletrificadas.

Os trilhos podem ser conectados entre si por soldas ou talas de junção. Ambas as técnicas possuem vantagens e desvantagens, sendo critérios de escolha determinadas características como: o tipo de via, a carga por eixo, a velocidade de 
operação, a densidade de tráfego, a geometria do trecho (curva ou tangente) e as condições climáticas da região. Descontinuidades nos trilhos e defeitos nas rodas dos trens causam o aumento da carga dinâmica e, por conseguinte, maior impacto nesses pontos, gerando zonas de acelerada degradação e intervenções de manutenção frequentes, principalmente quando utilizadas talas de junção.

Os acessórios metálicos de apoio e de fixação têm a função de conectar os trilhos aos dormentes, de modo que os mesmos resistam à movimentação lateral, longitudinal, vertical e de torção (transmitidas pelas rodas), e aos esforços oriundos da variação de temperatura (FORTUNATO, 2005). Quando da utilização de dormentes de madeira, deve-se empregar placas de aço sob os trilhos, o que implica em uma distribuição das forças por uma maior área de contato do dormente, reduzindo a pressão na madeira e protegendo-a de desgastes mecânicos. Quando da utilização de dormentes de concreto, muitas vezes são empregados elementos resilientes ("pads") também sob os trilhos, com a finalidade de amortecer as vibrações, reduzir o atrito entre o trilho e o dormente e promover um isolamento elétrico dos circuitos da via (SELIG e WATERS, 1994).

Os dormentes podem ser de madeira, concreto protendido reforçado, aço ou polímero, sendo os dois primeiros os tipos mais comumente empregados nas vias permanentes brasileiras. Esses componentes da superestrutura são assentados sobre o lastro compactado, a distâncias predefinidas um dos outros, e têm como principais funções: i) servir de plataforma plana e resiliente para os trilhos, garantindo a geometria transversal dos mesmos; ii) receber as cargas por eixo e transmiti-las em níveis de tensões aceitáveis para a camada de lastro; e iii) ancorar a superestrutura ferroviária, impedindo movimentações verticais, laterais e longitudinais da grade (COSTA, 2016).

Devido à sua reduzida vida útil, alta taxa de degradação e maior tendência ao apodrecimento, juntamente ao crescimento da consciência ambiental e ecológica dos últimos anos, os dormentes de madeira têm sido substituídos por dormentes de concreto na construção e manutenção/reabilitação de vias permanentes (INDRARATNA et al., 2011). Estes têm ganhado espaço no mercado mundial e se constituído como a opção mais viável financeiramente, uma vez que os dormentes de 
aço ainda são consideravelmente mais caros e os de polímero ainda estão sendo melhor avaliados quanto ao seu desempenho em campo.

Apesar de serem mais rígidos, duráveis e mais pesados, resistindo melhor às forças laterais, verticais e longitudinais, os dormentes de concreto não são recomendados para o emprego em todas as situações. Segundo Indraratna et al. (2011), uma das desvantagens desses dormentes é o fato de não poderem ser cortados em padrões e dimensões diferenciadas para o emprego em aparelhos de transposição de vias (cruzamentos) e aparelhos de mudança de vias (AMVs). Ademais, em condições de elevado ciclo de carga e sob alto impacto das cargas dinâmicas, como ocorre em ferrovias do tipo Heavy Haul, o desgaste dos dormentes de concreto gera material fino que ocasiona a colmatação dos vazios do lastro, alterando a sua curva granulométrica e modificando a resposta elástica da via (ESVELD, 2001).

A camada de lastro constitui-se de materiais granulares, com alta permeabilidade e uniformemente graduados, inseridos acima da camada de sublastro, sob e ao redor dos dormentes. Dentre outras funções, o lastro tem por finalidade promover a estabilidade da grade ferroviária, atenuando e uniformizando as tensões aplicadas pela passagem do material rodante e pelo peso próprio da via às camadas subjacentes, além de desempenhar a importante função de drenar a água decorrente de precipitações para fora do pavimento.

Os agregados que compõem o lastro podem ser de vários tipos e origens: rochas fragmentadas (arenito, basalto, calcário, gnaisse, granito, entre outras), cascalho, areia, agregado siderúrgico ou ainda outros materiais alternativos. O critério de escolha de agregados para constituir a camada de lastro varia quanto ao enquadramento do mesmo em limites aceitáveis no que concerne ao tamanho, forma, mineralogia, resistência ao desgaste, rigidez, durabilidade, permeabilidade, facilidade de limpeza (desguarnecimento e socaria) e valor de aquisição e transporte (HAY, 1982).

A capacidade de suporte da camada de lastro às solicitações verticais é consideravelmente maior que às solicitações laterais. Esveld (2001) ressalta que dois 
tipos de comportamento são imprescindíveis para a camada de lastro: a curto prazo, a capacidade de retornar à condição inicial de geometria após sofrer deflexões consequentes das forças aplicadas pela passagem dos trens, e, a longo prazo, resistir à deformação permanente e à degradação.

Entre a camada de lastro e o solo de fundação está inserida a camada de sublastro, como parte integrante da subestrutura do pavimento ferroviário. Seu dimensionamento é feito de forma a desempenhar as seguintes funções: proteger o subleito do excesso de carga que pode causar deformações permanentes ou ruptura por cisalhamento do solo (função estrutural); drenar a água acumulada na camada de lastro para os dispositivos de drenagem adequados e dissipar o excesso de poropressão que venha a ascender do subleito (função filtro); e evitar a penetração de grãos do lastro na camada de subleito e a migração de partículas finas do subleito para o lastro (função separação).

Os materiais que compõem a camada de sublastro podem ser de ocorrência natural (extração em cavas ou barrancos, caso dos materiais de origem aluvionar e sedimentar), agregados britados (obtidos por processos de detonação de maciços rochosos e posterior britagem dos blocos resultantes) ou a combinação de ambos (BARRA, 2009). Sua composição granulométrica é bem graduada, diferentemente do lastro, caracterizando-a como uma camada de transição. É compactada de forma a atingir uma rigidez superior à do solo de fundação, objetivando uma distribuição de tensões mais uniforme e significativamente reduzida para o subleito, como já mencionado.

O sublastro possui um papel importante no desempenho estrutural da via permanente, no entanto, pode não ser utilizado caso outra solução de engenharia satisfaça aos requisitos de separação, drenabilidade e suporte necessários. Selig e Waters (1994) citam como alternativas individuais ou combinadas para o emprego de sublastro granular convencional: camadas de reforço do subleito através de estabilização por adição de cimento, cal ou betume; aplicações de materiais geossintéticos (geomembranas, geocélulas, geogrelhas e geotêxteis) e camadas de concreto asfáltico (escopo deste trabalho). 
Como plataforma sobre a qual o sublastro e todo o restante do pavimento ferroviário é construído encontra-se o subleito. É constituído por solo (natural ou selecionado) e tem como papel suportar as cargas oriundas da passagem do material rodante e da via permanente, já adequadamente atenuadas pelos vários componentes da via, sem apresentar excessivos recalques. O subleito configura-se como um assentamento estável e estrutura de incontestável importância no desempenho do pavimento (PROFILLIDIS, 2006).

As condições do subleito variam dentro da extensão da ferrovia, quanto à composição e ao desempenho mecânico dos solos, e quanto aos aspectos hidrológicos locais, o que impacta no aumento ou na redução das suas propriedades de apoio resiliente e na sua capacidade de suporte. Caso a via precise ser construída, por exemplo, em regiões de solo mole, técnicas de tratamento precisam ser empregadas para reduzir a deformabilidade e melhorar a resistência da camada. Portanto, é necessário conhecimento de princípios de mecânica dos solos para o ideal dimensionamento, construção e manutenção do subleito e, por conseguinte, do pavimento ferroviário como um todo.

\subsubsection{Esforços atuantes}

A compreensão da origem e magnitude das forças aplicadas à via permanente constitui-se passo fundamental para o correto dimensionamento e análise do pavimento ferroviário. Forças verticais, laterais e longitudinais (Figura 2) atuam de forma simultânea e são distribuídas irregularmente ao longo da ferrovia, tornando-se uma tarefa difícil quantificá-las. As solicitações provenientes da complexa combinação de cargas estáticas e dinâmicas são repassadas à subestrutura através da interface dormente-lastro, previamente tendo percorrido o sistema de interação roda-trilhodormente da superestrutura (INDRARATNA et al., 2011). 
Figura 2. Esquema de forças aplicadas pela passagem da roda nos trilhos

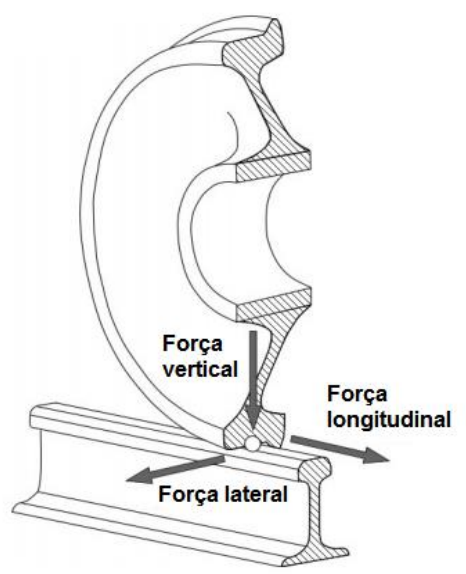

Fonte: adaptado de Zerbst et al., 2009.

As forças verticais são resultado da presença de massas suspensas e não suspensas do material rodante (carga estática), da movimentação dessas massas (carga dinâmica) e da variação de temperatura nos trilhos (contração e dilatação térmica). Estas forças atuam perpendicularmente ao plano dos trilhos e configuram-se como parâmetro decisivo para a gerência de pavimentos no que concerne à execução de manutenções corretivas. Quando submetidos às forças verticais, os componentes da superestrutura tendem a ter comportamento elástico, enquanto os componentes da subestrutura, materiais geotécnicos em sua maioria, apresentam comportamento elastoplástico (PROFILLIDIS, 2006).

Adotando a hipótese de que a variação de temperatura nos trilhos é nula, a força vertical total aplicada ao sistema é resultado unicamente da soma das parcelas das cargas estática e dinâmica. $O$ valor desta combinação em princípio determina a capacidade mínima de suporte que a via permanente deve possuir (ESVELD, 2001). As magnitudes mais significativas de tensões e deformações que ocorrem no pavimento são consequência da aplicação de carregamentos dinâmicos, expressas geralmente mediante um fator majorador da carga estática, também chamado fator de impacto.

O conhecimento das variáveis consideradas para fins de cálculo das cargas dinâmicas e, por conseguinte, das cargas verticais totais aplicadas à via, de forma alguma torna a sua obtenção um procedimento simples. Irregularidades geométricas, mudanças na 
rigidez das camadas da subestrutura e descontinuidades nas rodas dos trens e/ou nos trilhos intensificam a parcela majoradora da carga estática, acompanhadas ainda da influência da velocidade de operação e das cargas por eixo. Frente à tamanha dificuldade em reportar e quantificar precisamente todas essas variáveis, estabeleceuse como mais acessível na engenharia ferroviária a realização de análises estruturais do pavimento por meio da medição da resposta mecânica da via frente a solicitações, e não pela maneira inversa, a partir da determinação das cargas aplicadas.

\subsubsection{Comportamento mecânico}

A resistência à deflexão é função da rigidez da via. Deflexões verticais em excesso são indesejadas, pois geram deformações permanentes nas camadas da subestrutura e desgaste dos componentes da superestrutura, por isso devem manter-se dentro de um limite aceitável para que o pavimento ferroviário desempenhe seu papel de estrutura elástica atenuadora e dissipadora de tensões (HAY, 1982). Para fins deste estudo, foi utilizada a formulação desenvolvida por A. N. Talbot, em 1918, a qual considera o trilho como uma viga continuamente suportada por apoio elástico, devido à sua fácil compreensão e ampla aplicação (COSTA, 2016).

Conforme detalhado por Hay (1982) e esquematizado na Figura 3, a carga aplicada no trilho por um conjunto de rodas é distribuída sobre dormentes adjacentes em magnitude decrescente à medida que os mesmos se distanciam do ponto de aplicação, sendo a parcela de carga recebida por cada dormente dependente dos seguintes fatores: a) módulo de rigidez e momento de inércia da seção transversal do trilho; b) dimensões, espaçamento e módulo de rigidez dos dormentes; e, c) módulo de rigidez (ou de resiliência) das camadas de lastro, sublastro e subleito. 
Figura 3. Distribuição de cargas na via permanente

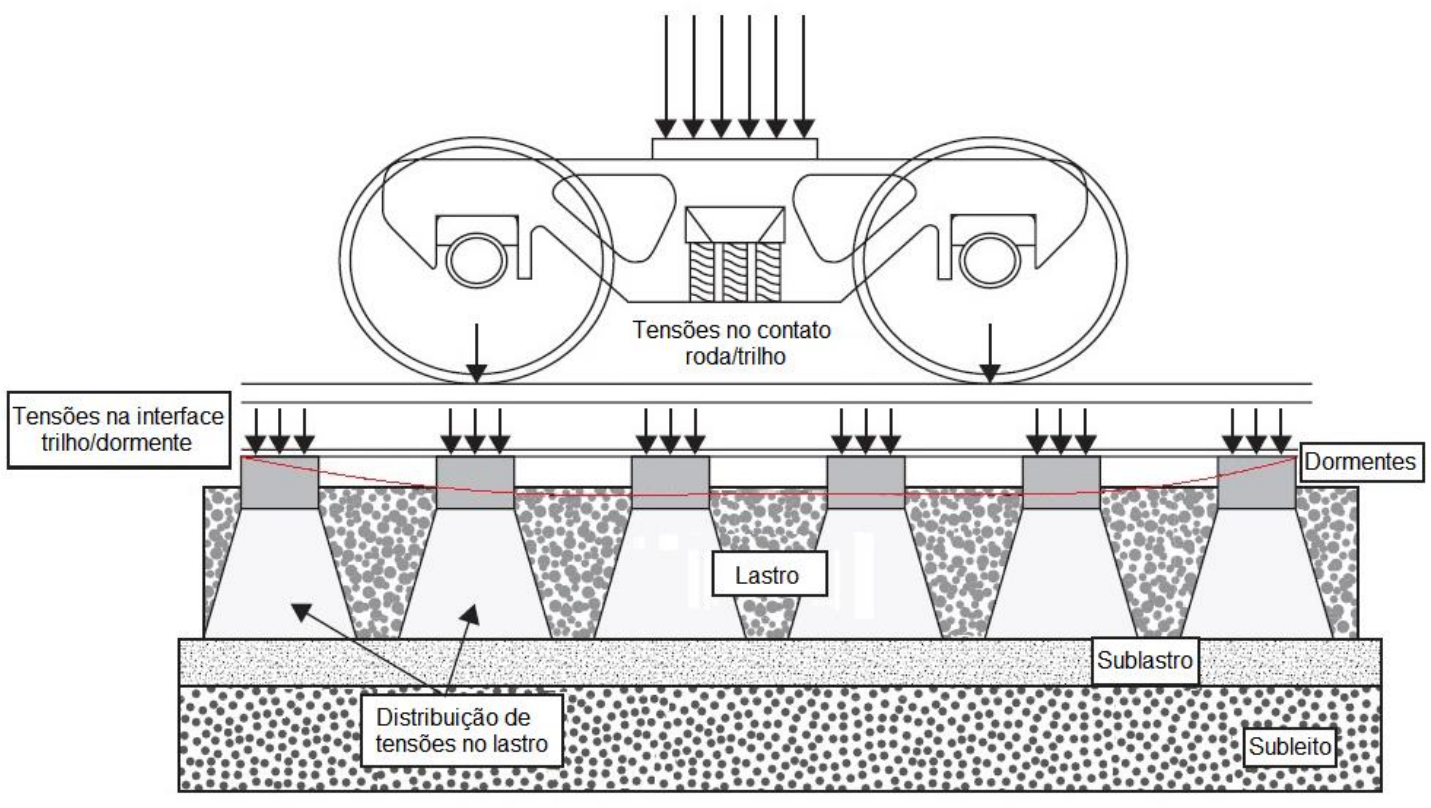

Fonte: adaptado de Indraratna et al., 2011.

A relação fundamental proposta por Winkler e Schwedler (citados por Hay em 1982), considerando o modelo de viga sobre apoio elástico de Talbot, representa o comportamento da via como função do carregamento (Equação [1]):

$$
p=-u y
$$

Onde: $p=$ força por unidade de comprimento $(\mathrm{kN} / \mathrm{m})$;

$u=$ módulo de via $(\mathrm{kPa}) ; \mathrm{e}$,

$y=$ deflexão da via $(m)$.

O módulo de via, $u$, é definido, portanto, pela força por unidade de comprimento necessária para aplicar uma deflexão vertical unitária no trilho. A convenção negativa do módulo de via indica a reação em sentido contrário à deflexão oriunda da aplicação das cargas verticais. Através da resolução da equação diferencial (Equação [2]), considerando a deflexão do trilho a qualquer distância ao longo de sua extensão, a partir de um carregamento simples, chega-se à equação geral de deflexão (Equação [3]). 


$$
\begin{gathered}
E I \frac{d^{4} y}{d x^{4}}+u y=0 \\
y(x)=\frac{P}{\left(64 E I u^{3}\right)^{1 / 4}} e^{-\lambda x}(\cos \lambda x+\operatorname{sen} \lambda x)
\end{gathered}
$$

Onde: $E=$ módulo de elasticidade do trilho $(\mathrm{kPa})$;

$I=$ momento de inércia do trilho $\left(\mathrm{m}^{4}\right)$;

$P=$ carga da roda $(\mathrm{kN})$;

$e=2,7183$ (Neperiano);

$\lambda=\left(\frac{u}{4 E I}\right)^{1 / 4}=$ fator de amortecimento; e,

$x=$ distância para qualquer ponto, a partir do carregamento ao longo do trilho (m).

As derivadas sucessivas da equação de deflexão fornecem a inclinação, o momento fletor no trilho (Equação [4]), o cisalhamento e a intensidade do carregamento (COSTA, 2016).

$$
M(x)=\frac{P}{4 \lambda} e^{-\lambda x}(\cos \lambda x-\operatorname{sen} \lambda x)
$$

A deflexão máxima ocorre subsequentemente ao ponto de aplicação do carregamento, onde $x=0$. Substituindo $x=0$ na Equação [3], obtém-se a Equação [5], de deflexão máxima $\left(y_{0}\right)$ :

$$
y_{0}=\frac{P}{\left(64 E I u^{3}\right)^{1 / 4}}
$$

O módulo de via (u) é então calculado pela Equação [6]:

$$
u=\frac{\left(\frac{P}{y_{0}}\right)^{4 / 3}}{(64 E I)^{1 / 3}}
$$


Além da influência que os valores de módulo de via, momento fletor e deflexões máximas sofrem devido a variações nas características dos componentes da superestrutura, a devida atenção deve ser igualmente dada ao fenômeno de superposição de cargas e às condições em que se encontram as camadas da subestrutura, principalmente a camada de lastro. Costa (2016), a partir de medidas de deslocamentos verticais "in situ" com trens operando a diferentes velocidades, apresenta que a densificação da camada de lastro, eventuais mudanças no tráfego solicitante e manutenções para correção geométrica são fatores preponderantes nos valores de deslocamento medidos e, consequentemente, nos valores calculados de módulo de via.

Costa (2016) também constatou, ao comparar medidas de deslocamento tomadas no patim do trilho e na borda do dormente, que os valores médios entre as amplitudes máximas medidas diferiam a depender da localização dos sensores. O mesmo ressalta que o tipo de dormente pode influenciar neste parâmetro, assim como a velocidade de operação e a magnitude das cargas aplicadas com a passagem do material rodante. Dessa forma, utiliza os valores de deslocamento obtidos no patim do trilho (local de máxima deflexão) para cálculo do módulo de via, em detrimento dos valores de deslocamento medidos na borda do dormente, configuração análoga à adotada para obtenção deste parâmetro no presente trabalho.

\subsubsection{Parâmetros geométricos}

O acúmulo de carga e as solicitações ambientais impostas à via permanente acarretam 0 desgaste de seus componentes (superestrutura) e camadas (subestrutura). De modo geral, a qualidade da via é definida por um conjunto de parâmetros cujos valores limites estão relacionados a um intervalo de tolerância definido de acordo com as características mecânicas e geométricas do trecho em questão (SILVA, 2006). Segundo Profillidis (2006), problemas relacionados à classe de parâmetros geométricos são geralmente reversíveis, enquanto aqueles relacionados à classe de parâmetros mecânicos requerem, na maior parte dos casos, que componentes e materiais geotécnicos sejam substituídos, implicando em onerosos desprendimentos financeiros de manutenção. 
Desvios entre valores medidos e teóricos de características da via são chamados de defeitos, e o reconhecimento destes contribui para diagnosticar a condição do pavimento e sinalizar a necessidade de restauro, por intermédio de intervenções de manutenção. Defeitos com precedentes funcionais são tratados através de manutenções preventivas e corretivas, já aqueles de origem estrutural devem ser cuidadosamente evitados ainda na fase de concepção da via, a fim de garantir espessuras mínimas de camadas e integridade e qualidade dos materiais empregados, por exemplo.

Os principais defeitos geométricos estão relacionados ao alinhamento longitudinal e vertical da via (nivelamento), alargamento e estreitamento de bitola, inclinação (superelevação) e empeno (Figura 4).

Figura 4. Parâmetros geométricos de via permanente

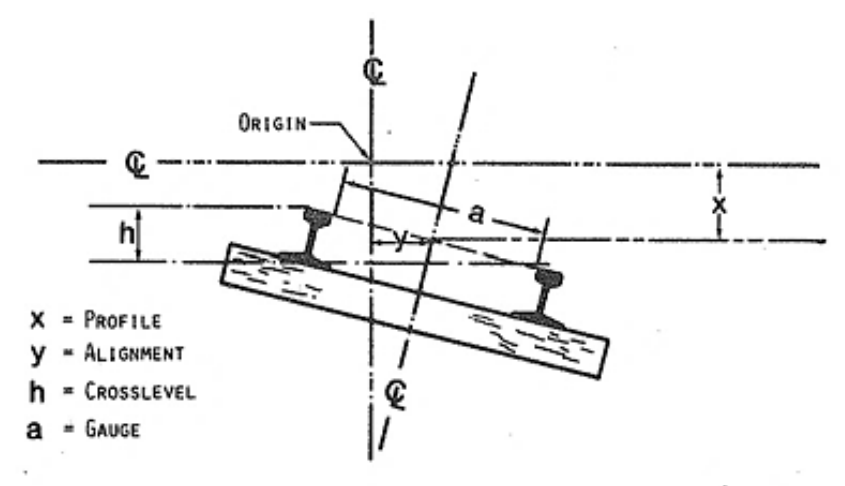

Fonte: Bing e Gross, 1983.

Qualquer variação na elevação da grade ferroviária em relação a um nível longitudinal predeterminado é designada desnivelamento ("x = profile"), enquanto a variação lateral da grade em relação a uma determinada linha central da via constitui-se como desalinhamento (" $\mathrm{y}=$ alignment"). A medida de bitola é a distância entre os trilhos interno e externo, medida a $16 \mathrm{~mm}$ abaixo da superfície superior do boleto do trilho ("a = gauge"). $\mathrm{O}$ alargamento ou estreitamento desta ocorre quando existem variações acima ou abaixo do valor de bitola adotado na via, respectivamente. Inclinação e empeno, por sua vez, estão associados à superelevação da via. A inclinação ("h = crosslevel') constitui-se como a variação vertical entre os trilhos interno e externo. Esta, em curvas, ajuda a compensar a força centrífuga do veículo e é especificada em projeto (superelevação), não sendo considerada defeito, a menos que se desvie do 
valor predefinido. Já o empeno, também chamado de torção, representa a diferença na superelevação entre dois pontos tomados a uma distância fixa ao longo da linha, geralmente a $10 \mathrm{~m}$ e a $20 \mathrm{~m}$ (BERAWI et al., 2010).

\subsection{Sublastro de mistura asfáltica}

\subsubsection{Histórico de utilização}

\section{Estados Unidos da América}

Nos Estados Unidos da América, registros da incorporação de misturas asfálticas na subestrutura de vias permanentes como prática consolidada datam de meados de 1980, apesar das primeiras experiências terem ocorrido, de fato, entre os anos de 1968 e 1969 (HUANG et al., 1987; ROSE e BRYSON, 2009). A princípio, o emprego desta técnica visava somente à reabilitação de trechos problemáticos no que concerne à estabilidade da via, ou seja, na manutenção de áreas onde a estrutura granular convencional não atendia aos limites satisfatórios de desempenho. A Santa Fe Railway, atualmente parte da BNSF Railway, e a L\&N Railroad/Seaboard System, predecessora da CSX Transportation, foram as companhias ferroviárias que prontamente se engajaram na adoção de camadas asfálticas para o incremento da capacidade estrutural de suas linhas (ROSE et al., 2011).

Segundo Rose et al. (2011), a inserção de uma camada betuminosa como componente do pavimento ferroviário pode ser realizada em três diferentes configurações. A Figura 5 esquematiza o que se chama "ballastless asphalt combination" ou "overlayment", uma estrutura de pavimento na qual os dormentes ou slab tracks (monolítico ou bibloco) estão diretamente assentados na camada asfáltica. Esta configuração possui ainda um sublastro granular entre a camada asfáltica e o subleito, além de uma contenção lateral (cribbing), essencial para evitar deslocamentos laterais e longitudinais da grade ferroviária. A Figura 6 ilustra as demais configurações, a "asphalt combination" e a "asphalt underlayment", que incorporam o lastro como camada de suporte tradicional. A primeira caracteriza-se pela combinação de sublastro asfáltico e sublastro granular, este último assentado 
sobre o subleito; e a segunda constitui-se pela substituição total do sublastro granular por um sublastro de mistura asfáltica.

Figura 5. Ballastless asphalt combination

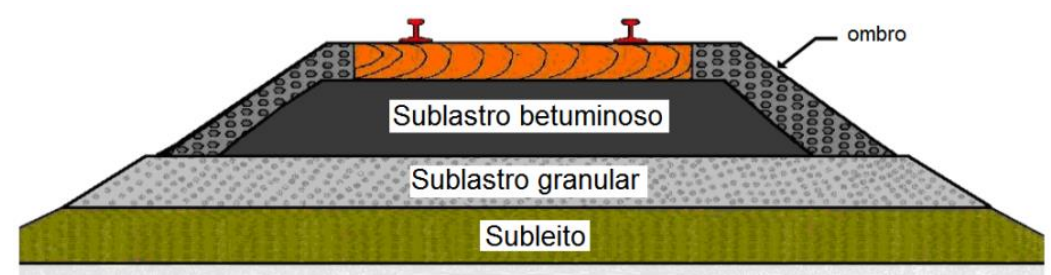

Fonte: adaptado de Rose et al., 2011.

Figura 6. (a) Asphalt combination e (b) Asphalt underlayment

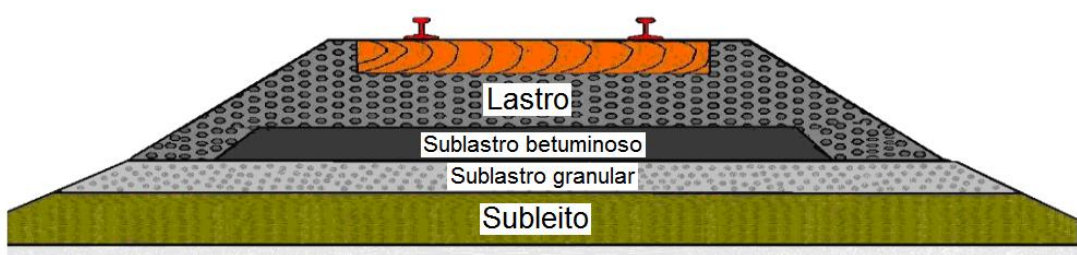

(a)

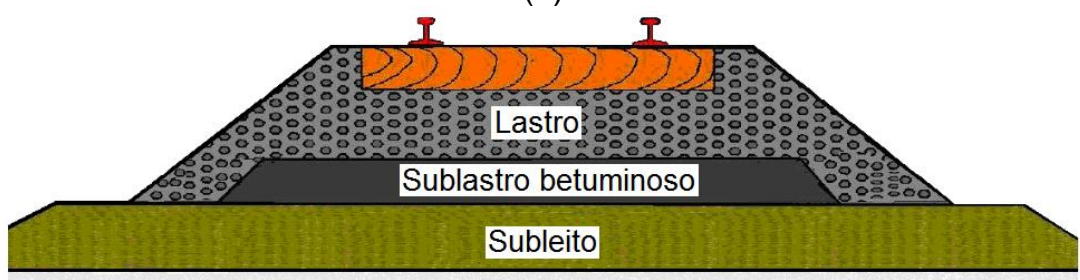

(b)

Fonte: adaptado de Rose et al., 2011.

Bryson e Rose (2009) afirmam que, dentre as configurações acima citadas, a maneira mais comum de inserir uma camada betuminosa na subestrutura de vias permanentes consiste na substituição total do sublastro granular (asphalt underlayment). Huang et al. (1987) destacam que, dos pontos de vista econômico e prático, underlayments são mais apropriados pois demandam menores espessuras de camada asfáltica e preservam condições da via de forma a corroborar para que processos de manutenção convencionais sejam aplicados sem sofrer adaptações.

O mais longo trecho de linha singela com sublastro betuminoso em operação nos EUA está localizado a leste de Amarillo, Texas, e é operado pela BNSF Railway. A linha, pela qual trafegam trens de passageiros e de carga, estende-se ainda pelos estados de Oklahoma e Kansas (ROSE et al., 2011). Após estudos e acompanhamentos de trechos experimentais por parte da companhia, a linha foi duplicada para aumento de 
sua capacidade e seu processo construtivo se deu pela inserção de uma camada asfáltica de $150 \mathrm{~mm}$ de espessura, diretamente sobre o subleito, e uma camada de lastro de $300 \mathrm{~mm}$ de espessura. Atualmente são mais de $322 \mathrm{~km}$ de sublastro betuminoso construídos em projetos no meio oeste americano, a maioria em ferrovias de carga, com carga por eixo média de 32 toneladas para as locomotivas e de 7 toneladas para os vagões descarregados (ROSE e SOULEYRETTE, 2015).

Itália

$\mathrm{Na}$ Europa, diferentemente dos EUA, o emprego de misturas asfálticas em ferrovias tem seu enfoque na construção de novas linhas para passageiros, principalmente as de alta velocidade de tráfego. Dentre os países europeus, a Itália se destaca pela ampla experiência no emprego desta técnica, possuindo mais de $1.200 \mathrm{~km}$ de vias construídas com sublastro betuminoso, e com avanços inclusive no estudo da incorporação de novos materiais, como o asfalto borracha, visando elevar o desempenho da subestrutura ferroviária e, consequentemente, da via como um todo (RANGEL et al., 2015; ALBANAT et al., 2011).

Albanat et al. (2011) reportam que, em 1970, durante a construção da primeira linha de alta velocidade italiana, a chamada Direttissima, que liga Roma a Florença, a Companhia Ferroviária Italiana (Ferrovie dello Stato) determinou que a capacidade de carga mínima da via deveria ser de $180 \mathrm{MPa}$ (módulo de deformabilidade equivalente obtido no ensaio de carga estática com placa), a fim de que a mesma resistisse adequadamente às solicitações impostas por aquele tipo de tráfego. Dessa forma, duas opções de materiais para compor a camada de sublastro foram testadas: uma composição de material granular tratado com cimento (misto-cementato) e uma mistura betuminosa (Figura 7). 
Figura 7. Seções experimentais italianas (linha Direttissima)
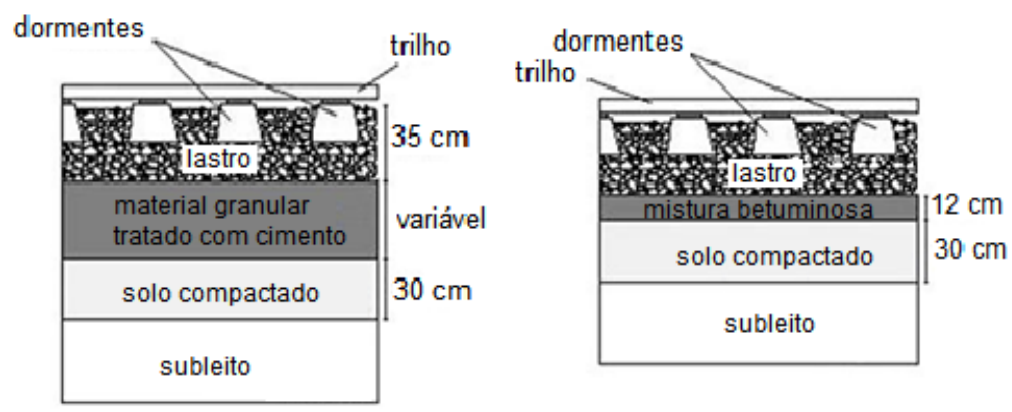

Fonte: adaptado de Teixeira, 2011.

O monitoramento destas seções revelou um bom desempenho estrutural da mistura asfáltica a curto e longo prazos, juntamente com economia em termos de aquisição e transporte de material granular, quando comparada à solução convencional. A Ferrovie dello Stato decidiu, a partir de então, empregar essa técnica nas demais seções da via Direttissima, solicitando, no entanto, que a mistura betuminosa atendesse aos seguintes requisitos (BUONANNO, 2000 apud ROSE et al., 2011):

- Prevenir que água oriunda de precipitações infiltrasse nas camadas granulares subjacentes;

- Reduzir o nível de tensões que atingiam o subleito;

- Proteger o subleito dos ciclos de congelamento/descongelamento;

- Amenizar e distribuir de maneira mais homogênea as cargas estáticas e dinâmicas aplicadas na via pela passagem dos trens; e,

- Eliminar o desgaste das partículas granulares que compõem o lastro, pelo aumento do confinamento desta camada.

Di Mino et al. (2015) ressalta que um sublastro de material tratado com cimento teria, comparativamente à mistura asfáltica, menores custos de produção, além da crescente qualidade de desempenho físico e mecânico, uma vez que o carbonato de cálcio em agregados naturais sofre um processo de cura com o passar do tempo, assegurando a homogeneidade da camada, somando-se ainda ao fato de constituirse em um material com características impermeáveis. No entanto, esta solução envolve questionamentos no que tange à exploração de agregados naturais e outras problemáticas de viés ambiental de difícil quantificação, à sensibilidade ao congelamento a certas temperaturas e à necessidade de isolamento ou selagem da 
camada com emulsões betuminosas, a depender das condições climáticas da região. Ademais, o surgimento e propagação de trincas em camadas tratadas com cimento constitui-se como fator agravante, pois possibilita a infiltração de água e o bombeamento de material da camada subjacente através das fissuras.

Assim, o pavimento ferroviário italiano (Figura 8) é executado seguindo as seguintes especificações: subleito com módulo de deformabilidade mínimo de $40 \mathrm{MPa}$, sobre o qual está assentada uma camada de solo altamente compactado (supercompattato), com módulo de deformabilidade de $80 \mathrm{MPa}$ e 3,5\% de inclinação; uma camada betuminosa de $120 \mathrm{~mm}$ de espessura, com módulo de deformabilidade mínimo de 200 MPa (valor mínimo requerido para qualquer configuração de sublastro); e $350 \mathrm{~mm}$ de lastro. A camada de solo altamente compactado possui $300 \mathrm{~mm}$ de espessura e é composta por uma mistura de areia e agregado (cascalho), tendo por funções atenuar as tensões oriundas das solicitações do tráfego, a fim de que cheguem ao subleito com magnitudes inferiores àquelas admissíveis pelo solo, e favorecer a drenagem (POLICICCHIO, 2008 apud ROSE et al., 2011).

Figura 8. Corte transversal - Pavimento ferroviário italiano com sublastro betuminoso

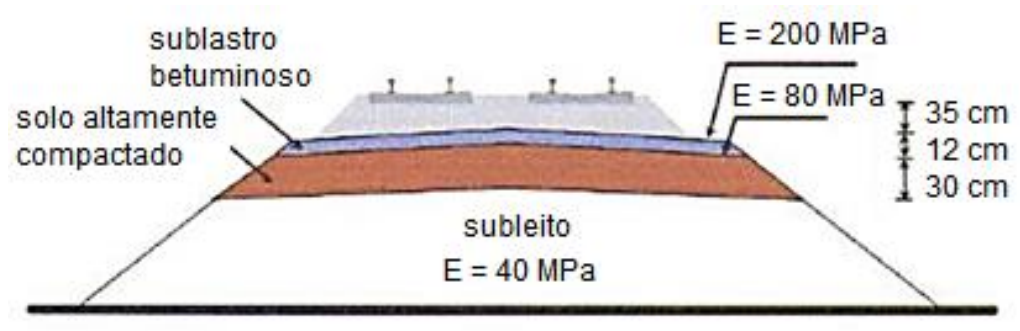

Fonte: adaptado de Teixeira, 2011.

França

A experiência da França teve início há pouco mais de uma década, com a construção e a instrumentação de um trecho contendo sublastro betuminoso na linha de alta velocidade que liga Paris a Estrasburgo, sob a condução da Companhia Ferroviária Nacional Francesa (SNCF). Desde 2004, quando a construção foi iniciada, a via permanente tem sido analisada quanto à perda de qualidade, no que concerne à geometria, e à eficiência, pautada em dados referentes a intervenções de manutenção (CARDONA et al., 2016). 
Por meio de análises do desvio padrão de medidas de alinhamento vertical da via (ou nivelamento longitudinal), medidos entre 2007 (início da operação) e 2016, Cardona et al. (2016) citaram que a seção com sublastro betuminoso exibia melhores resultados que aquelas construídas com sublastro granular convencional, pelas quais circulam trens franceses do tipo TGV-R e TGV-POS e alemães do tipo ICE3, com carga por eixo média de 17 toneladas. Em oito anos, dez intervenções mecanizadas do tipo socaria foram necessárias na via de referência, contrapondo-se a somente uma na via com sublastro betuminoso. Vale ressaltar que os trechos analisados eram subjacentes, a fim de assegurar o mesmo regime de tráfego e as mesmas condições climáticas.

Sabendo-se que o aumento do desvio padrão de medidas de alinhamento vertical é uma indicação clara da degradação da via e que o mesmo é considerado o parâmetro mais representativo para 0 acionamento de práticas de manutenção, Cardona et al. (2016) concluíram que o emprego de mistura asfáltica como camada de sublastro reduz a velocidade de degradação do pavimento ferroviário como um todo. Em vista disso, quatro novos projetos de linhas de passageiros de alta velocidade estão sendo construídos na França contendo, parcialmente ou por completo, sublastro betuminoso. A seção transversal típica francesa (Figura 9) substitui os $50 \mathrm{~cm}$ de sublastro granular por uma camada de mistura asfáltica de 14 $\mathrm{cm}$ de espessura.

Figura 9. Seção transversal típica francesa antes e depois da inserção da camada betuminosa

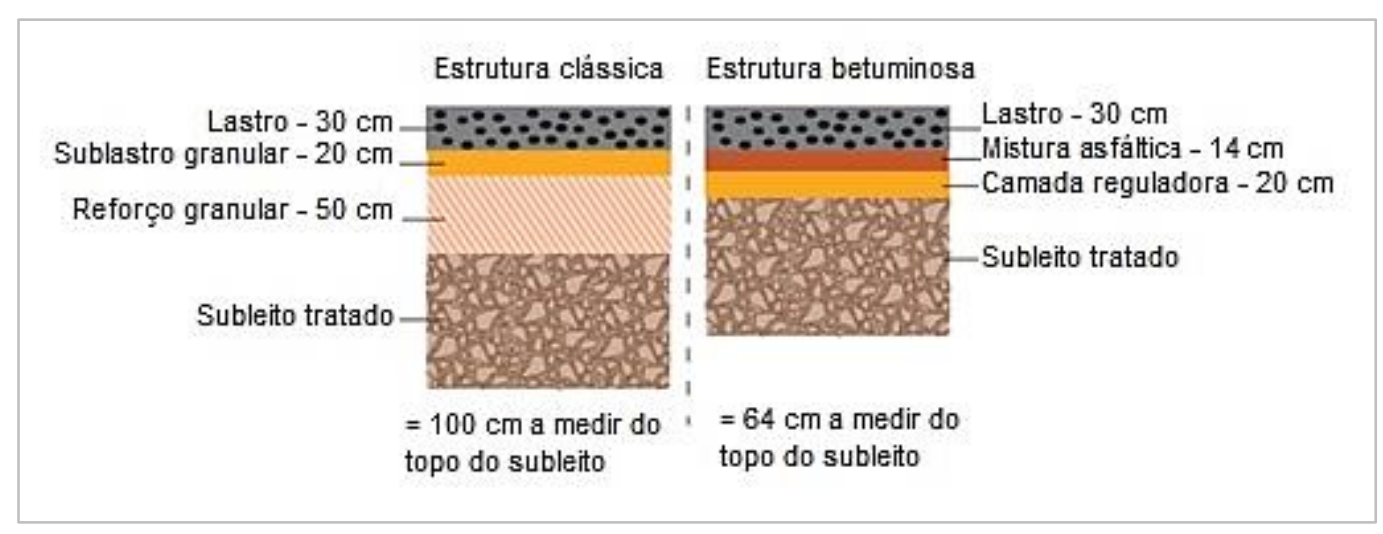

Fonte: adaptado de Rose et al., 2011. 


\section{Outros países}

No Japão, assim como na Itália, o emprego de sublastro betuminoso é síncrono à construção da primeira linha de alta velocidade e data de meados de 1960. O objetivo principal dos japoneses era solucionar problemas causados por irregularidades em algumas seções das linhas (ALBANAT et al., 2011). Logo, o primeiro dimensionamento possuía somente $50 \mathrm{~mm}$ de espessura de mistura asfáltica combinada a uma camada granular com espessura variável, entre $150 \mathrm{~mm}$ e $600 \mathrm{~mm}$, a depender da qualidade do subleito.

Em 1970, a partir da constatação de diversas outras melhorias na resposta da via permanente, tais como a eliminação total do bombeamento de finos e da redução da deformação do subleito, juntamente com a melhoria das condições de drenagem; o emprego de mistura asfáltica passou a ser prática comum na construção de novas linhas, fossem elas de alta velocidade ou não (DI MINO et al., 2012). O dimensionamento da camada é feito baseado no desempenho, sendo considerações primárias a deformação permanente da via e a vida de fadiga da mistura asfáltica (ROSE et al., 2011).

Áustria e Alemanha também registram experiências bem-sucedidas com o emprego de mistura asfáltica em suas vias permanentes. O primeiro trecho austríaco data de 1963 e é caracterizado pela inserção de uma fina camada betuminosa (entre 80 e 120 $\mathrm{mm}$ de espessura) abaixo do lastro, preservando o sublastro granular convencional sobre o subleito. Em 1995 fez-se necessária a renovação da superestrutura desta região e foi verificado que a mistura asfáltica não havia sofrido danos e não necessitava de reparos, o que comprova a longevidade da camada e reduz questionamentos quanto à manutenção da mesma (ROSE et al., 2011). Na configuração alemã, as vias permanentes não possuem lastro, ou seja, encaixam-se na categoria "ballastless asphalt combination" ou "overlayment". Consistem em uma camada betuminosa de 260 a $300 \mathrm{~mm}$ de espessura sobre as quais estão assentados os dormentes de concreto, e objetivam, principalmente, a redução de custos de manutenção e a preservação dos recursos naturais. 
Recentemente, a Espanha tem se destacado por investimentos em pesquisas e construção de trechos experimentais com sublastro betuminoso em suas ferrovias (TEIXEIRA et al. 2010). Diversas simulações para dimensionamento do pavimento e análises de custo foram desenvolvidas baseadas nas experiências de outros países europeus, culminando com a execução de seções-teste na linha de passageiros de alta velocidade que liga Madri a Valladolid e na linha de tráfego misto que liga Barcelona a Perpgnan (França).

Cardona et al. (2016) citam também a construção de uma linha de alta velocidade no Marrocos, ligando Tangier a Kenitra (200 km), com emprego de sublastro betuminoso em toda sua extensão e previsão de operação a partir de 2018.

No Brasil, análises do comportamento estrutural do pavimento ferroviário com emprego de camadas betuminosas a partir de simulações numéricas tiveram destaque nos últimos anos. Motta et al. (2014) e Rangel et al. (2015), fazendo uso de dados representativos da realidade nacional para estimar espessuras de sublastro betuminoso, trouxeram à tona a necessidade da execução de trechos experimentais, a fim de validar tais modelos, bem como de pesquisas relativas à viabilidade técnica e aos custos de implantação desta solução. Porém, até o presente momento, não se verificam registros de experiências práticas de aplicação desta técnica no país.

\subsubsection{Dimensionamento}

A viabilidade do emprego de sublastro betuminoso em vias permanentes deve ser avaliada quanto a diversos aspectos. Do ponto de vista teórico, para que sejam atendidos critérios de projeto e cumpridas especificações normativas para a construção de pavimentos ferroviários, os seguintes parâmetros de dimensionamento devem ser considerados (TEIXEIRA et al., 2006):

- Tensões verticais e nível de aceleração (vibração) na camada de lastro, como um indicador de possíveis deformações permanentes;

- Tensão horizontal de tração na fibra inferior da camada de sublastro betuminoso, como um indicador da sua vida de fadiga; e, 
- Tensões verticais no topo do subleito, como um indicador do comportamento da camada a longo prazo e vida útil do pavimento como um todo.

As primeiras experiências com sublastro betuminoso atendiam a parâmetros de dimensionamento desenvolvidos para a área rodoviária, quando não eram realizadas de maneira empírica. Rose e Bryson (2009) afirmam que a mistura asfáltica utilizada nos últimos 25 anos pelas companhias ferroviárias americanas possui seu dimensionamento similar àquele de camadas de base de pavimentos chamados de "perpétuos" no meio rodoviário. De forma geral, o que se espera dessa mistura é um comportamento flexível, para que seja capaz de suportar deslocamentos excessivos sem apresentar trincas, e baixa permeabilidade, devido ao reduzido teor de vazios em comparação com um sublastro granular convencional.

No entanto, é sabido que as configurações de tráfego e a distribuição de tensões ao longo das camadas do pavimento ferroviário ocorrem de forma diferenciada daquelas verificadas em pavimentos rodoviários. Portanto, simulações mais representativas das condições particulares às quais o sublastro betuminoso se encontra passaram a ser uma preocupação frequente dentre os pesquisadores há pouco mais de uma década. Trabalhos desenvolvidos por Teixeira et al. (2006), Albanat et al. (2011), Di Mino et al. (2012) e Rangel et al. (2015), envolvendo modelos numéricos representativos de condições de campo, complementados por resultados de ensaios de laboratório e de registros da literatura, têm norteado a engenharia ferroviária quanto a espessuras ideais de camada e à dosagem dessas misturas asfálticas.

Teixeira et al. (2006) afirmam que em quase todas as linhas de alta velocidade europeias construídas até este ponto, apenas materiais granulares (areia e cascalho) têm sido empregados na composição do sublastro. A espessura desta camada, independentemente do material que a constitui, vai depender do nível de tensão máximo suportado pelo subleito e das propriedades intrínsecas dos materiais que compõem a estrutura do pavimento (Rangel et al., 2015).

Devida atenção deve ser dada à qualidade da camada asfáltica empregada em pavimentos ferroviários. Rose et al. (2011) reportam que estudos e acompanhamentos 
de trechos experimentais têm comprovado a redução da necessidade de manutenções nas vias como um todo, no entanto, uma vez degradada, a camada betuminosa encontra-se em difícil posição para reabilitação. Diversos questionamentos relativos ao processo de manutenção de camadas asfálticas vêm surgindo, à medida que as vias atingem certa idade ou um histórico de tonelagem específico. Cardona et al. (2016) alertam para a necessidade de se entender o processo de degradação de vias com sublastro betuminoso por meio da caracterização do comportamento mecânico das misturas asfálticas sob condições de carregamentos ferroviários e, por conseguinte, estabelecer padrões de dimensionamento.

\section{Espessura}

O programa computacional KENTRACK, baseado na teoria de multicamadas elásticas, foi desenvolvido para projetar e analisar o comportamento estrutural de pavimentos ferroviários com a possibilidade de se inserir uma camada asfáltica. Por intermédio de simulações numéricas é possível estimar-se a magnitude das tensões que atingem o topo da camada de subleito, incorporando os efeitos da variação dos seguintes elementos: cargas por eixo, tonelagem, condições ambientais, capacidade de suporte do subleito, espessuras das camadas e propriedades dos materiais geotécnicos. Além disso, uma vez inserida uma camada de sublastro betuminoso, é possível realizarem-se também análises das tensões horizontais de tração na fibra inferior da camada betuminosa. As previsões quanto à vida de fadiga e ao comportamento estrutural da via permanente são feitas através da análise de danos, calculados com base nos critérios de falha para rodovias estipulados pelo Instituto de Asfalto Norte-Americano (ROSE e UZARSKI, 2011).

Fazendo uso do KENTRACK, Teixeira et al. (2006) realizaram um estudo paramétrico comparando a solução tradicional de sublastro granular com uma solução teórica de sublastro betuminoso. O objetivo principal desta análise era determinar os requisitos mínimos necessários à camada de sublastro betuminoso para que fossem atendidos os critérios de projeto de linhas de alta velocidade espanholas. Para tal, o cálculo da carga dinâmica foi feito através de adaptações de algoritmos obtidos em guias e 
especificações francesas, buscando a incorporação dos efeitos das massas suspensas e não suspensas nos valores finais de cargas verticais. Foram consideradas no estudo cargas por eixo referentes a três modelos de materiais rodantes (AVE 101 da fabricante Alstom TGV, AVE 102 de fabricação de TalgoBombardier 350 e AVE 103 da fabricante Siemens ICE 3 - aproximadamente 17 ton/eixo), três diferentes velocidades de operação e três níveis de qualidade da linha (alta, média ou baixa, a depender da quantidade de irregularidades geométricas).

O resultado para simulação de uma via de baixa qualidade e velocidade de operação de $300 \mathrm{~km} / \mathrm{h}$ demonstrou que, mantendo-se similares as respostas de tensãodeformação para ambas as estruturas, a espessura da camada de sublastro betuminoso ( $9 \mathrm{GPa}$ ) deve estar entre 120 e $140 \mathrm{~mm}$ para que seja capaz de substituir eficazmente uma camada de sublastro granular (200 MPa) de $300 \mathrm{~mm}$ de espessura. Vale ressaltar que os níveis de tensão no lastro, assim como sua espessura, e a capacidade de suporte do subleito foram mantidos nas duas soluções estudadas (TEIXEIRA et al., 2006).

A análise também mostrou que o aumento da espessura é mais efetivo, no que tange à resposta mecânica da via, que o aumento da rigidez da mistura asfáltica. Quanto à vida de fadiga, usando-se critérios baseados na tensão horizontal de tração na fibra inferior da camada betuminosa, foi encontrado que, com solo de subleito com módulo de deformabilidade mínimo de $80 \mathrm{MPa}$, a fadiga da mistura ocorre após ruptura do subleito. Provou-se, assim, que a camada asfáltica se comporta adequadamente durante toda a vida útil do pavimento.

Em 2011, Albanat et al. realizaram estudo paramétrico similar ao de Teixeira et al. (2006), porém fazendo uso do software de elementos finitos ANSYS, e adotando hipóteses de viscoelasticidade linear para a mistura asfáltica e de comportamento elastoplástico (Drucker-Prager) para as camadas granulares. O resultado obtido no modelo computacional reafirmou a faixa de espessura de camada betuminosa (120 a $140 \mathrm{~mm}$ ) obtida por Teixeira et al. (2006), para que a resposta em termos de tensõesdeformações fosse equivalente àquela obtida por uma camada de sublastro granular convencional. Ainda corroborando com os resultados obtidos por Teixeira et al. (2006), 
Albanat et al. (2011) verificaram que o aumento da espessura da camada betuminosa é mais significativo para a redução das tensões que chegam ao subleito que o aumento do valor de módulo de resiliência da mistura asfáltica.

Di Mino et al. (2012) desenvolveram um modelo 2D para ferrovias com quatro níveis de elasticidade, a fim de compreender as tensões de cisalhamento atuantes na camada de lastro e as tensões de flexão atuantes na camada de sublastro betuminoso. O modelo foi utilizado para estudar a possibilidade do emprego de asfalto borracha no sublastro de novas linhas de alta velocidade italianas. Comparações entre o comportamento mecânico e a deformação de três estruturas diferentes mostraram que, quando adotado sublastro betuminoso com $120 \mathrm{~mm}$ espessura (independente do teor de borracha contido na mistura), em contraponto ao sublastro granular altamente compactado de $300 \mathrm{~mm}$ de espessura, as pressões máximas dinâmicas experimentadas pela via eram reduzidas em 40\%. Da mesma forma, a aceleração vertical na estrutura convencional granular apresentava valores superiores aos encontrados para estrutura com sublastro betuminoso.

A simulação feita por Di Mino et al. (2012) prezou por avaliar uma condição estrutural mais precária (subleito com módulo de deformabilidade de $20 \mathrm{MPa}$ ), velocidade de operação de $90 \mathrm{~km} / \mathrm{h}$ e carga por eixo de 20 toneladas, referente ao modelo de trem ALn 668 da fabricante FIAT, utilizado pela Ferrovie dello Stato e por diversas concessionárias ferroviárias italianas. O que se pôde observar dos resultados obtidos, mais uma vez, demonstra a capacidade da mistura asfáltica de melhor distribuir as tensões aplicadas pelas diversas camadas da subestrutura ferroviária, e que, para as condições europeias, uma espessura mínima de $120 \mathrm{~mm}$ satisfaz mecanicamente os requisitos necessários de projeto.

Rangel et al. (2015), afim de realizar análises mais representativas das vias permanentes nacionais, simulou por meio do software de elementos finitos ABAQUS 6.14 variações de módulo de resiliência (3.000, 6.000 e $9.000 \mathrm{MPa})$ e espessura de camadas de sublastro betuminoso $(50,75,100,125$ e 150 mm), e então comparou os resultados obtidos com aqueles provenientes da simulação de uma camada de sublastro granular padrão de 200 mm de espessura, com módulo de resiliência de 200 
MPa. Para todas as análises, o módulo de resiliência do subleito foi definido como 80 $\mathrm{MPa}$, o do lastro como $130 \mathrm{MPa}$ e carga por eixo de 32 toneladas, simulando uma ferrovia de carga pesada. Os dados relativos aos componentes da superestrutura seguiram as normas vigentes da ABNT NBR 7511 (2013) e os relativos às condições de tráfego foram obtidos da empresa pública VALEC, de 2015.

Dentre as várias constatações deste estudo, percebeu-se que uma maior rigidez da camada de sublastro betuminoso gera uma redução no deslocamento vertical medido no topo do trilho, em comparação ao obtido com o emprego de sublastro granular. Consequentemente, as maiores tensões verticais na camada de lastro foram registradas quando da simulação de camadas betuminosas espessas e rígidas. 0 aumento excessivo das tensões no lastro torna-se um fator preocupante, pois pode causar a degradação das partículas e a geração de finos, o que interfere na configuração da camada e na sua resposta mecânica. Ou seja, o aumento indiscriminado de módulos de resiliência e/ou espessuras de camadas de sublastro betuminoso podem ser prejudiciais ao comportamento estrutural da via permanente como um todo.

Ratificando o que foi constatado por Teixeira et al. (2006), Albanat et al. (2011) e Di Mino et al. (2012), Rangel et al. (2015) afirmam que a redução das tensões que atingem o subleito é mais relevante quando se aumenta espessura da camada de sublastro betuminoso do que quando se aumenta sua rigidez. Comparativamente à camada de sublastro granular, verifica-se redução da tensão no topo do subleito para camadas betuminosas acima de $100 \mathrm{~mm}$ de espessura e módulo de elasticidade maiores que $3.000 \mathrm{MPa}$. Dessa maneira, Rangel et al. (2015) recomendam a execução de camadas betuminosas possuindo, no mínimo $125 \mathrm{~mm}$ de espessura, principalmente em regiões com subleito de baixa capacidade de suporte.

\section{Dosagem e aplicação}

A mistura asfáltica utilizada para compor o sublastro de vias permanentes norteamericanas segue a especificação de misturas asfálticas densas para base de pavimentos rodoviários (Dense graded highway base mix), instituída pelo Instituto de 
Asfalto Norte-Americano, como mencionado anteriormente. O diâmetro máximo do agregado deve estar entre 25 e $37,5 \mathrm{~mm}$, e o teor de ligante deve ser acrescido em 0,5\% a partir do teor de projeto ("ótimo") para aplicações em rodovias, resultando em uma mistura com valores de módulo de resiliência médio ou baixo (comportamento predominantemente plástico). O teor de vazios de projeto deve estar entre 1 e $3 \%$, a fim de que seja possível a densificação em campo a menos de $5 \%$ de vazios, concedendo à camada uma rigidez adequada e um perfil impermeável (BRYSON e ROSE, 2009). O aumento do teor de ligante não se constitui uma preocupação no que concerne à deformação permanente, pois as pressões aplicadas no topo da camada de sublastro têm magnitudes bastante reduzidas quando comparadas àquelas sofridas por camadas de rolamento de pavimentos rodoviários.

A depender do tipo de instalação, diferentes equipamentos e configurações de seção são adotados. Geralmente, para linhas singelas, a largura da camada de sublastro é de aproximadamente 3,7 m, e sua espessura está entre 125 e $150 \mathrm{~mm}$. Para subleito de baixa capacidade de suporte e zonas de alto impacto dinâmico, até $200 \mathrm{~mm}$ de espessura da camada asfáltica é aceitável. A camada de lastro, por sua vez, permanece com espessura variando entre 200 e 300 mm, como na estrutura granular convencional. Segundo Bryson e Rose (2009), os equipamentos necessários para aplicação e compactação da mistura asfáltica vão desde escavadeiras, tratores de esteira, pás carregadeiras e rolos vibratórios de pequeno porte, para manutenções locais (Figura 10), até equipamentos de pavimentação convencionais e vibroacabadoras de grande porte para construção de novas vias (Figura 11). Lembrando que, para reabilitações, faz-se necessária a retirada prévia da grade ferroviária. 
Figura 10. Aplicação em cruzamento: (a) retirada da grade e (b) compactação da mistura

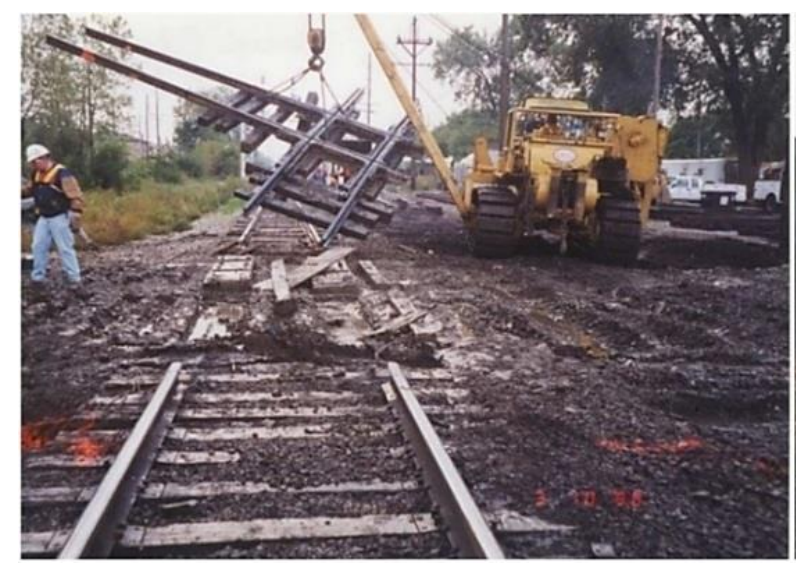

(a)

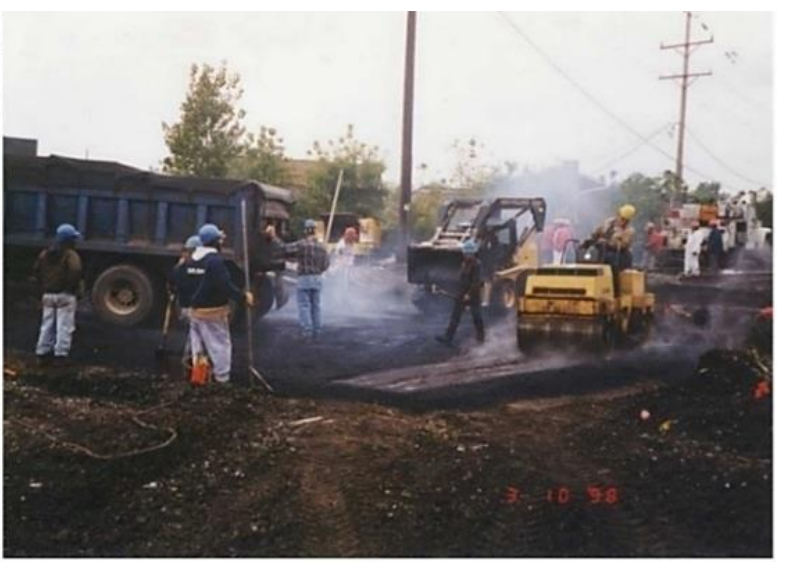

(b)

Fonte: Rose, 2011.

Figura 11. Aplicação em novas linhas

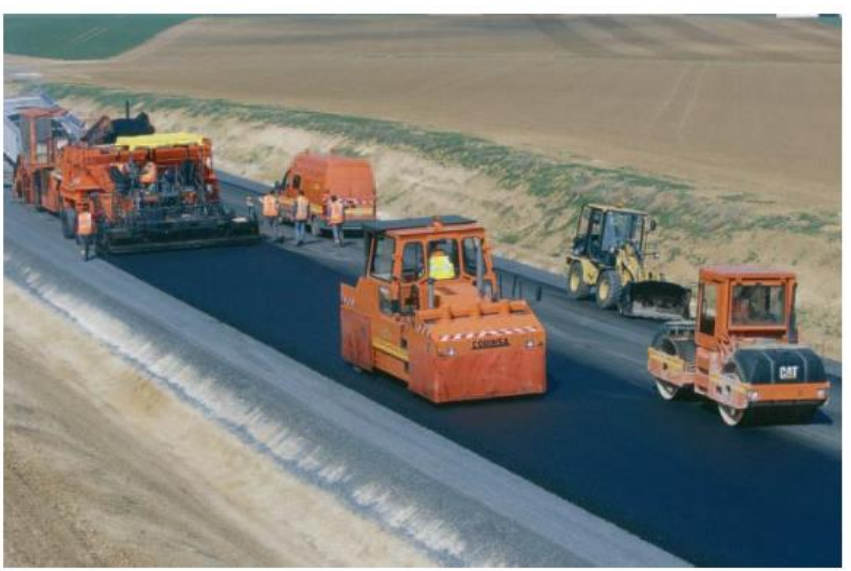

FONTE: Faure, 2005 apud Rose et al., 2011.

A compactação da camada deve alcançar um grau de compactação de 96 a 98\%, seguindo o padrão Marshall. Testes de verificação das especificações devem ser executados a cada $10.000 \mathrm{~m}^{3}$ e a verificação da resposta dinâmica da camada deve ser executada três vezes a cada $100 \mathrm{~m}$, com a utilização do Falling Weight Deflectometer (FWD) (ROSE et al., 2011).

Segundo Di Mino et al. (2015), o diâmetro máximo do agregado calcário predominantemente empregado em camadas de sublastro betuminoso na região oeste da Sicília (Itália) é de $25 \mathrm{~mm}$. O dimensionamento da mistura é feito por meio da metodologia Marshall e o teor de vazios ideal está entre 5 e 7\%. Rose et al. (2011) detalham que a mistura asfáltica italiana é compactada por rolos estáticos e 
vibratórios, e assentada sobre uma camada de solo altamente compactado de 300 $\mathrm{mm}$ de espessura, com módulo de deformabilidade de $80 \mathrm{MPa}$. Abaixo da camada de solo altamente compactado, o subleito deve apresentar módulo de deformabilidade de $40 \mathrm{MPa}$, no mínimo, e o controle de compactação do mesmo é feito a cada 2.000 $\mathrm{m}^{2}$. Os autores ainda reportam que a camada asfáltica é aplicada de forma a cobrir toda a seção transversal da via, possui espessura final de $120 \mathrm{~mm}$ e módulo de deformabilidade superior a $200 \mathrm{MPa}$.

Rose et al. (2011) também detalham o processo construtivo do trecho experimental francês, de $3 \mathrm{~km}$ de extensão. A seção foi executada, inicialmente, pela compactação de uma camada granular de $200 \mathrm{~mm}$ de espessura. A mesma foi revestida com emulsão asfáltica a uma taxa de $1,5 \mathrm{~kg} / \mathrm{m}^{2}$ e, em seguida, coberta por uma fina camada de agregados, com o propósito de evitarem-se possíveis danos causados pela passagem dos veículos e equipamentos de pavimentação utilizados na aplicação da camada asfáltica. Uma vez aplicada a mistura, com compactação a 96\% da densidade máxima, o mesmo procedimento de revestimento com emulsão e agregados foi realizado, mas com a redução da taxa para o valor de $0,8 \mathrm{~kg} / \mathrm{m}^{2}$.

Cardona et al. (2016) definem a mistura como um GB class 3 (Grave Bitume) pela norma europeia NF EN 13108-1-2007. Os autores afirmam que é uma mistura comum para os padrões de base de pavimentos rodoviários franceses, possuindo módulo complexo superior a $9 \mathrm{GPa}\left(\right.$ a $15^{\circ} \mathrm{C}$ e $\left.10 \mathrm{~Hz}\right)$.

\subsubsection{Vantagens da aplicação}

Diversas são as vantagens reportadas por pesquisadores e companhias ferroviárias com relação ao emprego de sublastro betuminoso em vias permanentes. Albanat et al. (2011) citam melhorias na condição estrutural e geométrica do pavimento como um todo, além de vantagens construtivas, econômicas e ambientais. Di Mino et al. (2012) afirmam que a utilização de mistura asfáltica reduziu valores de aceleração vertical, conduzindo a uma redução de tensões e, consequentemente, a uma degradação mais lenta do lastro ferroviário, camada da subestrutura com maior parcela de influência na resposta mecânica da via permanente. No entanto, há de se 
atentar para o fato de que, a depender da mineralogia do lastro, a inserção de uma camada mais rígida subjacente a este e o consequente aumento da tensão de confinamento pode ter efeito reverso e causar a quebra das partículas. Bryson e Rose (2009) constataram que, para misturas mais viscosas, como as dimensionadas para sublastro betuminoso, faz-se possível a leve penetração de partículas de agregados do lastro na superfície da camada asfáltica. Tal fenômeno aumentou a resistência ao cisalhamento interfacial, mantendo um alto grau de densificação do lastro, e, portanto, elevando o desempenho estrutural do pavimento.

Cardona et al. (2016) reportam um estudo feito pela SNCF que atesta a redução de $40 \%$ nos valores de desvio padrão de medidas de rigidez vertical tomadas ao longo da sua zona experimental com sublastro betuminoso. Os autores comentam que a maior rigidez e a homogeneidade da camada betuminosa, comparativamente a camada granular, acarretaria também uma redução no recalque diferencial da via, este ocasionado pela aplicação de cargas dinâmicas excessivas em linhas de alta velocidade. Sabendo-se que o recalque diferencial é um dos fenômenos causadores da perda de geometria de vias permanentes, a verificação da redução da frequência de manutenções corretivas de geometria na linha de alta velocidade que liga Roma a Florença, construída com sublastro betuminoso, vem corroborar com este pensamento. Teixeira et al. (2010) em colaboração com a Universidade de Roma vêm conduzindo estudos e análises mais aprofundadas destes indicadores, mas declaram que as constatações até este ponto já indicam um efeito positivo da utilização de sublastro betuminoso para a preservação da qualidade geométrica de vias.

Rose et al. (2002) acompanharam a variação das pressões que atingem as camadas da subestrutura da via permanente em duas localidades norte-americanas, por meio da instrumentação de trechos de ferrovias de carga construídos com sublastro betuminoso. Células de pressão hidráulica foram instaladas acima e abaixo da camada asfáltica, em diversas localizações, a fim de verificar em qual delas os picos de pressão são maiores e em quanto o sublastro betuminoso contribui para a redução desses picos na transmissão para a camada de subleito. 
Os resultados mostram que os picos de pressão ocorrem no eixo diretamente abaixo da interface trilho/dormente, e que, para uma carga por eixo média de 32 toneladas, os valores de pressão medidos ficaram entre 75 e $150 \mathrm{KPa}$, no topo da camada de sublastro betuminoso. No topo do subleito, como observado na Figura 12, há uma redução da pressão em cerca de 50\%, com picos variando entre 39 e $66 \mathrm{KPa}$. As medidas foram tomadas de forma dinâmica, com velocidade de operação de $64 \mathrm{~km} / \mathrm{h}$. A camada de lastro tinha espessura de $200 \mathrm{~mm}$, assim como a de sublastro. Li et al. (2002) caracterizaram o solo do subleito como uma argila com alto teor de umidade (média de 34,6\%), limite de liquidez médio de 64\% e plasticidade média de 38\%. A média de resistência não drenada foi de $90 \mathrm{kPa}$. Cardona et al. (2016) também reportam redução de pressões em $50 \%$ da camada de sublastro betuminoso para o topo da camada de subleito, e comentam que a possível causa desse fenômeno está relacionada à diferença do mecanismo de distribuição de tensões das camadas betuminosas comparadas com as granulares.

Figura 12. Redução das pressões medidas no topo das camadas

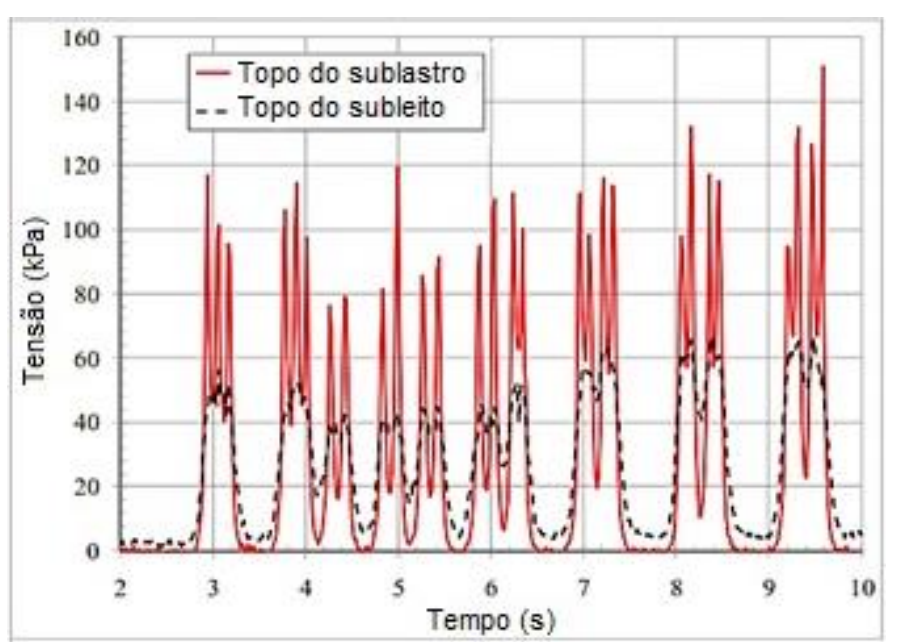

FONTE: adaptado de Rose et al., 2002.

Rose e Bryson (2009), em estudo desenvolvido para avaliar a integridade das misturas asfálticas empregadas em camadas de sublastro de ferrovias de cargas norteamericanas, também avaliaram as condições da camada de subleito destes trechos, após anos de solicitações. As diversas amostras extraídas e analisadas eram provenientes de configurações estruturais distintas, além de terem vivenciado condições ambientais diferenciadas e regimes de tráfego variados. No entanto, os resultados apontaram que os ligantes e misturas asfálticos não apresentavam 
qualquer indicação de endurecimento excessivo (fragilidade), envelhecimento ou deterioração. No que se refere ao teor de umidade das camadas do subleito, Rose e Bryson (2009) obtiveram valores "in situ" bem próximos daqueles obtidos em laboratório, indicando que a camada de sublastro betuminoso pode ser considerada, para fins de dimensionamento, como impermeável e mantenedora da condição de umidade do subleito próxima à ótima para máxima densidade.

Teixeira et al. (2010), após extensiva análise de custos, reportam que o fator chave para a composição do valor final de uma camada de sublastro convencional configurase na distância média de transporte do material granular (DMT). Pesquisas com valores levantados em 2005, na Espanha, indicam que, para uma distância de transporte média variando entre 60 e 80 km, a utilização de sublastro betuminoso seria mais econômica. Paralelamente, devido à qualidade impermeável do sublastro betuminoso, a inclinação necessária da camada poderia ser reduzida de 5\% (normatização espanhola para sublastro granular) para 3\% (adotado na Itália para sublastro betuminoso), reduzindo o volume da camada de lastro em cerca de 200 $\mathrm{m}^{3} / \mathrm{km} / \mathrm{via}$. Essa economia de lastro pode ser equivalente a, aproximadamente, $5 \%$ do valor do sublastro betuminoso, considerando o custo médio do material de lastro utilizado na Espanha (Figura 13).

Figura 13. Representação esquemática da economia de material de lastro

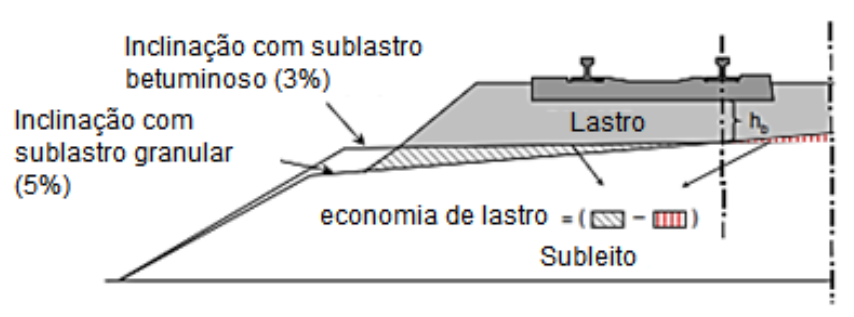

FONTE: adaptado de Teixeira et al., 2010.

Dentre outras vantagens reportadas, podem-se citar: inexistência do fenômeno de bombeamento de finos do subleito ou do sublastro para o lastro, reduzindo a colmatação e, assim, preservando a drenagem e as propriedades resilientes desta camada; controle de qualidade mais preciso devido a caracterização mais detalhada do material betuminoso, consequência de ensaios mais avançados e amplo know-how por parte dos profissionais da área de pavimentação para estruturas desse tipo; 
redução de vibrações e ruídos (importante para regiões residenciais); rápida liberação da camada para circulação de veículos e equipamentos durante a fase construtiva; e redução da quantidade de agregados minerais, face a redução da espessura da camada, e, por consequência, redução da exploração de jazidas (ALBANAT et al., 2011; CARDONA et al., 2016; RANGEL et al., 2015).

\subsection{Fatores influentes no comportamento da via com sublastro betuminoso}

O dimensionamento de camadas betuminosas para fins de pavimentação rodoviária objetiva reduzir a valores mínimos o aparecimento de defeitos (de superfície, funcionais e estruturais), que leve à diminuição do conforto, à insegurança dos usuários e à ruptura prematura da estrutura, e consequente redução da vida de projeto (ROSE e BRYSON, 2009). Deformações permanentes por trilha de roda; trincamento por fadiga; arrancamento, descolamento e desagregação causada pelo desprendimento de agregados da superfície ou perda de mastique junto aos agregados são alguns dos defeitos mais comumente encontrados em pavimentos flexíveis.

Quando consideradas camadas betuminosas para pavimentação ferroviária, Rose e Bryson (2009) afirmam, no entanto, serem mínimas ou inexistentes as condições causadoras de tais defeitos, já que as variações de temperatura na camada de sublastro betuminoso não atingem magnitudes capazes de provocar afundamento plástico (altas temperaturas) ou trincamento térmico (baixas temperaturas). Da mesma forma, a possibilidade de descolamento de película de asfalto junto ao agregado, devido à tensão de sucção gerada pelo contato pneu-pavimento na presença de água ou à falta de ligante é ausente, pois a transmissão de cargas ocorre através do contato roda-trilho, atingindo a camada de sublastro de maneira atenuada.

Estes pesquisadores também afirmam que, uma vez inserida como sublastro, a camada betuminosa está protegida de intempéries (incidência de radiação solar, precipitações e gradiente térmico), devido ao isolamento proporcionado pela camada de lastro. Ressaltam que, sendo a disponibilidade de oxigênio reduzida, tem-se, de maneira proporcional, uma redução no processo de envelhecimento e enrijecimento 
do ligante asfáltico. Tais constatações foram obtidas a partir de estudos comparativos das condições de amostras de camadas de sublastro betuminoso de vias permanentes norte-americanas. Caracterizações físicas e mecânicas destes corpos de prova mostraram que as misturas asfálticas não apresentaram indicações de enrijecimento, saturação, deterioração ou redução da vida de fadiga, mesmo sendo solicitadas pelo transporte de cargas durante longos períodos (entre 12 e 25 anos) e estando localizadas em regiões diferenciadas quanto às características ambientais.

Cardona et al. (2016) ressaltam, entretanto, que as misturas betuminosas empregadas em pavimentos ferroviários estão expostas a variações climáticas durante sua vida de serviço, principalmente no que concerne a mudanças nas condições de umidade, sejam estas oriundas de precipitações, acúmulo de água devido à ineficiência de dispositivos de drenagem ou ascensão do nível de água do subleito por capilaridade. Sendo assim, camadas de sublastro betuminoso não devem ser concebidas seguindo o padrão de dimensionamento de misturas para camadas de base de pavimentos rodoviários, como tem sido prática adotada na engenharia ferroviária.

\subsubsection{Comportamento viscoelástico das misturas asfálticas}

As misturas asfálticas, devido à presença de ligantes betuminosos em suas composições, são caracterizadas por um comportamento viscoelástico e termosuscetível, ou seja, têm seu desempenho afetado por fatores como o tempo, a taxa de aplicação das cargas solicitantes e as variações de temperatura em que ocorrem estas solicitações (RIVIÈRE, 1996; HUET, 1963 apud BARRA, 2009). Equitativamente, o estado de tensões no qual o material se encontra, o tipo e a frequência de carregamento que lhes é aplicado, a variação do teor de umidade e o envelhecimento do mesmo são fatores determinantes no desempenho mecânico da estrutura (KIM, 2009).

Buscando compreender-se e, por conseguinte, prever-se o comportamento de pavimentos, modelos das mais diversas naturezas (empíricos, semi-empíricos e mecanicistas) vêm sendo desenvolvidos desde os primórdios da engenharia de 
transportes. A partir da adoção de hipóteses simplificadoras como homogeneidade, isotropia e comportamento elástico linear; da resolução de equações analíticas e formulações matemáticas complexas, desenvolvidas para um espaço semi-infinito, como as propostas por Boussinesq (meios homogêneos) e por Burmister (meios estratificados); e do conhecimento das propriedades de deformabilidade e de resistência dos materiais constituintes de cada camada, conjugada a suas respectivas espessuras; faz-se possível o traçado de modelos capazes de prever a resposta do pavimento em relação à aplicação de cargas (VASSOLER et al., 2011).

Sendo os materiais viscoelásticos caracterizados por comportamentos peculiares, dada a sua elevada sensibilidade com a temperatura e a frequência de solicitações, constitui-se uma das tarefas mais complexas e críticas prever seu comportamento e definir quantitativamente as características intrínsecas às suas propriedades mecânicas (BARRA, 2009). Durante os anos cinquenta, pesquisadores e estudiosos passaram a avaliar e descrever o comportamento dinâmico de materiais viscoelásticos em seus trabalhos. Dentre eles, Nills O. Myklestad, em seu estudo intitulado The concept of complex damping, apresentou pela primeira vez o conceito de módulo complexo para representação do comportamento de um material viscoelástico (MOREIRA, 2004).

Àquela época, modelos reológicos simples obtidos por combinações de elementos elásticos (molas) e elementos viscosos (amortecedores) eram normalmente utilizados para representar o comportamento dos materiais viscoelásticos. Os elementos de Maxwell e de Kevin-Voigt foram os mais disseminados, aparecendo usualmente combinados em modelos múltiplos, e atualmente ainda são base para a formulação de vários outros modelos mais avançados (MOREIRA, 2004; BARRA, 2009).

O modelo generalizado de Maxwell (Figura 14) é representado pela combinação, em paralelo, de associações em série de uma mola e um amortecedor lineares, e de um componente elástico (BARRA, 2009). Neste modelo, $\sigma$ é a tensão aplicada sobre o corpo a fim de mantê-lo a uma deformação constante; $E$ e $\eta$ representam, respectivamente, as constantes dos elementos elástico (módulo de Young ou de elasticidade) e viscoso; e $E_{0}$ representa um elemento elástico responsável pelo 
comportamento assintótico dos materiais viscoelásticos, impedindo o retorno por completo da tensão ao seu estado inicial nulo (função de relaxação).

Figura 14. Modelo de Maxwell generalizado

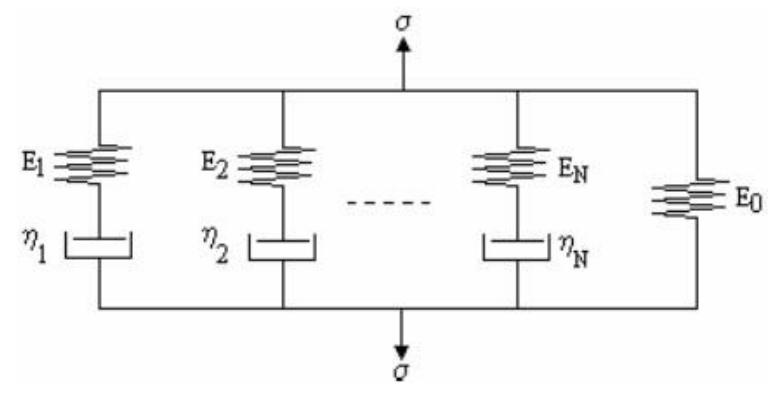

Fonte: Barra, 2009.

A função de relaxação expressa o comportamento mecânico de um corpo que, ao ser submetido à aplicação de uma deformação constante a uma dada temperatura, apresenta um decréscimo progressivo de tensão (BARRA, 2009). A Figura 15 traz a representação gráfica da função de relaxação, onde: $\tau$ é o tempo de aparição da solicitação, t é o tempo de observação da resposta à solicitação aplicada e $\theta$ é a temperatura na qual se encontra o material. Quando a tensão relaxa até zero, podese dizer que o modelo representa um material fluído.

Figura 15. Representação gráfica da função de relaxação
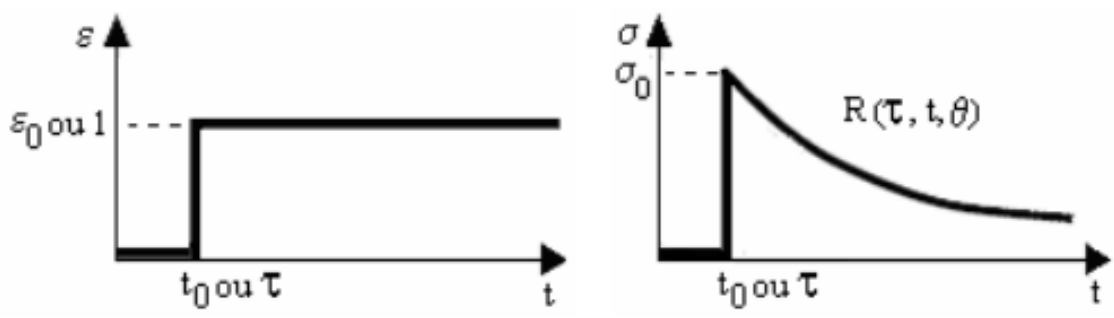

Fonte: Barra, 2009.

O modelo generalizado de Kevin-Voigt (Figura 16), semelhante ao de Maxwell, também é representado pela combinação, em série, de associações em paralelo de uma mola e um amortecedor lineares, e um componente elástico (BARRA, 2009). Neste modelo, $\sigma$ é a tensão constante aplicada sobre o corpo; E e $\eta$ são as constantes dos elementos elástico (módulo de Young ou de elasticidade) e viscoso; e $E_{0}$ 
representa um elemento elástico linear instantâneo retornável quando cessada a aplicação de tensão nos materiais viscoelásticos (função de fluência).

Figura 16. Modelo de Kevin-Voigt generalizado

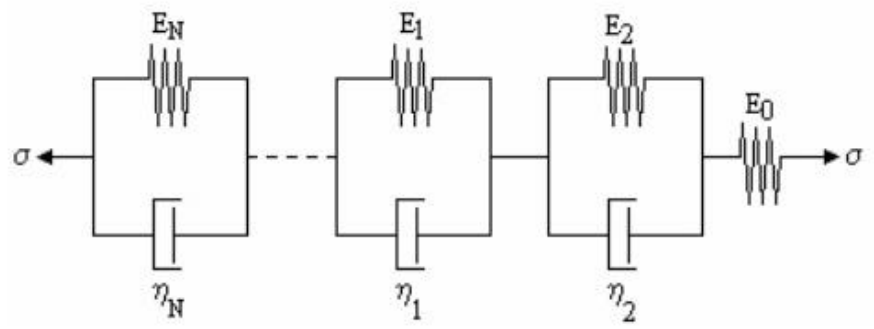

Fonte: Barra, 2009.

A função fluência, também conhecida como função de retardo, expressa o comportamento mecânico de um corpo que, ao ser submetido à aplicação de uma tensão constante a uma dada temperatura, apresenta um aumento progressivo de deformação (BARRA, 2009). A função de fluência, sendo dual da função de relaxação, também depende das variáveis $\tau$, t e $\theta$ (Figura 17).

Figura 17. Representação gráfica da função de fluência
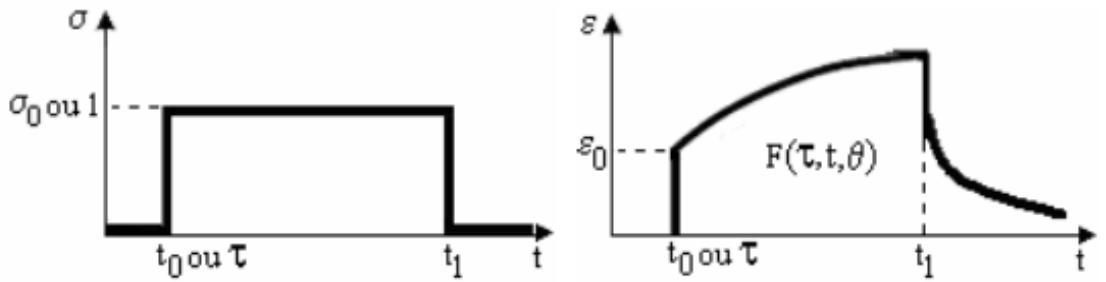

Fonte: Barra, 2009

Um material puramente elástico apresenta deformações imediatamente após a aplicação da carga, ou seja, possui tensões e deformações correspondentes em fase (ângulo de fase nulo). Contrariamente, um material puramente viscoso apresenta deformações defasadas da aplicação de carga, o que infere em ângulos de fase de $90^{\circ}$. Em materiais viscoelásticos, no entanto, acontece uma combinação de respostas elásticas e viscosas dependentes do tempo de aplicação da carga e da temperatura. Em outras palavras, existe uma defasagem relativa $\varphi$ entre a deformação $\varepsilon(t)$ obtida 
e a tensão $\sigma(\mathrm{t})$ imposta pelo carregamento, como mostrado na Figura 18 (BALBO, 2007; OTTO, 2009).

Figura 18. Solicitação senoidal e ângulo de fase dos materiais viscoelásticos

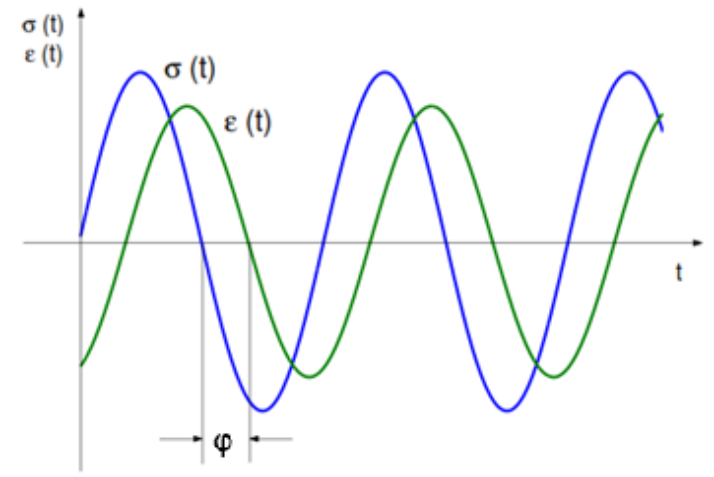

Fonte: adaptado de Moreira, 2004.

Os procedimentos laboratoriais mais empregados para obtenção de parâmetros de deformabilidade de misturas asfálticas são: o ensaio dinâmico de módulo complexo e o ensaio de módulo de resiliência. O primeiro consiste na aplicação de deformações cíclicas a um corpo de prova através de um carregamento do tipo harmônico, sendo medidas, simultaneamente, a carga aplicada e a deformação imposta pelo material viscoelástico, juntamente com a defasagem existente entre os seus respectivos sinais, ou seja, o ângulo de fase (MOREIRA, 2004). Os tipos de ensaio de módulo complexo podem ser classificados em duas categorias: homogêneos e não homogêneos. A primeira contempla as formas de ensaio pelas quais se obtêm diretamente os valores de tensão e de deformação, enquanto a segunda engloba aquelas que consideram a estrutura geométrica do corpo de prova para a obtenção destes valores.

O ensaio de módulo de resiliência (MR) pode ser realizado por meio da aplicação de cargas repetidas no plano diametral vertical de um corpo de prova cilíndrico regular. É definido como a relação entre a tensão dinâmica aplicada e a consequente taxa de deformação recuperável (deslocamento resiliente), medida na direção horizontal correspondente à tensão gerada, numa dada temperatura (BERNUCCl et al., 2008). O módulo de resiliência, juntamente com o coeficiente de Poisson, constitui-se como parâmetro representativo do comportamento dos materiais quando utilizada a teoria da elasticidade, podendo ser obtido através da Equação [8]. As deformações elásticas 
recuperáveis são medidas através de LVDTs (linear variable differential transformers), de elevada sensibilidade, após elevado número de ciclos de carregamento repetido (N). As cargas devem ser suficientemente baixas, quando comparadas à resistência do material (geralmente cerca de $15 \%$ desta última), assegurando que 0 comportamento deste permaneça dentro da zona elástico-linear.

$$
M R=\frac{F}{100 \times \delta_{r} \times h}(0,9976 \mu+0,2692)
$$

Onde: $F=$ carga vertical repetida aplicada diametralmente no corpo de prova $(\mathrm{N})$;

$\delta_{r}=$ deslocamento elástico ou resiliente para $\mathrm{N}$ aplicações de carga $(\mathrm{cm})$;

$\mathrm{h}=$ altura do corpo de prova $(\mathrm{cm}) ; \mathrm{e}$,

$\mu=$ coeficiente de Poisson, adotado 0,3 para misturas asfálticas.

\subsubsection{Variação da condição de umidade do subleito}

A deformação permanente em camadas geotécnicas da subestrutura ferroviária é um fenômeno que deve ser evitado, uma vez que ocorre de maneira diferencial ao longo do perfil longitudinal da via e gera problemas relativos à perda de geometria, significando uma maior necessidade de intervenções de manutenção (altos custos desprendidos). Adicionalmente ao efeito das cargas dinâmicas, a variação das condições climáticas atuantes no pavimento ferroviário influencia de forma significativa a resposta mecânica dos materiais granulares e, por conseguinte, da via como um todo. Mudanças nos valores de tensão de sucção do solo, por exemplo, devido a processos de umedecimento e secagem desse material, a depender do seu tipo, correspondem a variações de maior ou menor magnitude em seu volume (fenômenos de contração e expansão) que, por sua vez, aceleram o processo de degradação das camadas, reduzindo a rigidez e a capacidade de suporte das mesmas (FERREIRA et al., 2011; CARDOSO et al., 2012).

Ademais, quando utilizado sublastro de mistura asfáltica, uma das maiores preocupações no que tange a integridade da mistura é a caracterização da sua vida de fadiga. Recalques diferenciais do subleito acarretaram maiores esforços de flexão 
na camada asfáltica e uma provável redução da sua vida útil. Assim, uma análise vanguardista dos materiais geotécnicos com viés termo-hidro-mecânico tem surgido no meio ferroviário, embasada em estudos desenvolvidos na engenharia geotécnica para análise do comportamento de solos não saturados.

Ferreira et al. (2011) simularam, por meio de um software computacional de elementos finitos CODE_BRIGHT, a deformação permanente que ocorre no topo da camada de subleito em duas situações distintas: via permanente com sublastro betuminoso de $120 \mathrm{~mm}$ de espessura e via com sublastro granular de $300 \mathrm{~mm}$. Este programa soluciona, com equações inseridas pelo usuário, cálculos relativos ao balanço hídrico, considerando a condição dos solos como não saturada e deformável. O objetivo do estudo em questão era verificar o quanto a deformação na camada de subleito é reduzida ao ser utilizada uma camada de sublastro betuminoso, considerando que 0 mesmo funciona como uma camada impermeabilizante do subleito.

A resposta obtida pelos pesquisadores, quando inseridas condições características do clima da Espanha e realizadas análises elásticas para um horizonte de cinco anos de solicitações, foi uma redução de quase $60 \%$ nos valores de deslocamento vertical no topo do subleito no perfil com sublastro betuminoso, em comparação à estrutura granular convencional. Demais aspectos também foram observados, como o destacado fato da amplitude das deformações ser proporcional à amplitude da oscilação dos valores de tensões de sucção sofridas pelas camadas granulares (FERREIRA et al., 2011).

Entretanto, a análise de Ferreira et al. (2011) simula situações características da região de clima mediterrâneo e comportamentos dos solos baseados em equações generalistas, assumindo comportamentos hidráulico e mecânico semelhantes para materiais de origens e características distintas. A experiência advinda de análises de solos de subleito de perfis rodoviários brasileiros tem demonstrado, no entanto, que as condições dos solos do tipo tropical, por exemplo, por vezes não se encaixam de maneira adequada às classificações internacionais, sendo necessários estudos específicos para a correta compreensão do comportamento característico dos mesmos. 
Camacho (2002), em estudo das peculiaridades de distribuição de umidades em bases de pavimentos de solo arenoso fino laterítico, verificou que os teores de umidade medidos no eixo de rodovias de bases granulares mostravam-se menores que os teores medidos nas bordas das camadas. Os perfis de sucção, por outro lado, mostravam-se crescentes em sentido contrário ao das umidades, demonstrando que a distribuição das sucções matriciais se encontra em uma situação de desequilíbrio entre os diversos pontos de uma mesma camada, o que induz à existência de fluxos de água entre eles. O autor conclui, dentre outros aspectos, que falar em umidade de equilíbrio de determinada camada parece inadequado, fazendo-se necessária uma caracterização mais detalhada dos fluxos de água em camadas de solo para a compreensão da movimentação de frentes de umidade e sua correlação com as medidas de resistência destas.

\section{Fluxos de água}

Um determinado ponto de uma camada granular poderá perder água para outros pontos contíguos através de fluxos internos estabelecidos entre eles, como também pode receber água daqueles e de outros pontos, quando alteradas as condições de contorno (CAMACHO, 2002). Admitindo-se a hipótese de equilíbrio dinâmico, onde os potenciais relativos se mantivessem dentro da camada, a condição nula de variações das umidades em cada ponto com o tempo seria predominante. No entanto, tal condição ideal não existe na prática, onde as umidades nas camadas granulares compactadas modificar-se-ão em função das variações das condições meteorológicas, as quais determinam alterações nos fluxos para dentro e para fora dela. Dentre os fenômenos caracterizados pela movimentação de água em camadas, pode-se citar:

- Fenômeno da percolação;

- Infiltração lateral a partir do acúmulo de água nas bordas do pavimento e a partir de acostamentos umedecidos por chuvas;

- Infiltração vertical de águas de chuvas e/ou de águas acumuladas através de trincas ou de superfície permeável; e,

- Elevação de águas provenientes do lençol freático (capilaridade), induzida por gradientes térmicos e de sucção matricial. 
O fluxo da água segue a lei de Darcy, desenvolvida para meios saturados. Apesar de não ser suficiente para o estudo dinâmico da água nos solos não saturados, ainda é usada como aproximação do seu comportamento, uma vez que não existe equação válida e amplamente confirmada no meio científico para fluxos não saturados. Iwata et al. (1995) afirmam que, à medida que o solo se torna mais seco, maior a possibilidade de discrepâncias entre o fluxo real e aquele descrito pela lei de Darcy. Dessa forma, o estudo de fluxos não saturados em solos engloba: a) a determinação das sucções matriciais, as quais podem ser obtidas experimentalmente, e apresentadas na forma de curvas características ou de retenção dos solos, incluindose aí as indeterminações associadas à histerese, e b) a determinação dos coeficientes de permeabilidade não saturada, ou condutividades não saturadas, que também variam com o teor de umidade do solo.

\section{Sucção em solos}

Marinho (1997) define sucção como uma pressão de água intersticial, fruto de condições físico-químicas, que faz com que o solo absorva ou perca água, dependendo das condições ambientais, aumentando ou diminuindo seu grau de saturação. A Equação [8] define a sucção total, ou seja, a energia livre da água intersticial em um solo não saturado, e foi descrita por Fredlund e Rahardjo (1993):

$$
\Psi=\frac{R \cdot T}{v_{w 0} \omega_{v}} \cdot \ln \left(\frac{u_{v}}{u_{v 0}}\right)
$$

Onde: $\Psi$ = sucção do solo ou sucção total $(\mathrm{kPa})$;

$\mathrm{R}=$ constante universal dos gases $(=8,31432 \mathrm{~J} /(\mathrm{mol} \mathrm{K}))$;

$\mathrm{T}=$ temperatura absoluta $(\mathrm{K})$;

$v_{w}=$ volume específico da água ou do inverso da densidade da água $\left(\mathrm{m}^{3} / \mathrm{s}\right)$;

$\omega_{v}=$ massa molecular do vapor de água dos poros $(=18.016 \mathrm{~kg} / \mathrm{kmol})$;

$u_{v}=$ pressão parcial de vapor de água dos poros $(\mathrm{kPa}) ; \mathrm{e}$,

$u_{\nu 0}=$ pressão de saturação do vapor de água sobre uma superfície plana de água pura a mesma temperatura $(\mathrm{kPa})$. 
Para uma temperatura de referência de $20^{\circ} \mathrm{C}$, obtém-se a Equação [9]:

$$
\Psi=-135022 \ln \frac{u_{v}}{u_{v 0}}
$$

O termo $u_{v} / u_{v 0}$ é chamado de umidade relativa do ar, $\mathrm{RH}(\%)$. Camacho (2002) explica que, por meio da determinação da sucção com a Equação [9], os valores podem ser representados em forma de gráfico, gerando a curva de retenção de água no solo.

A sucção total, tratada até o presente momento, é resultado da soma das parcelas de sucção matricial, relacionada à matriz do solo, e osmótica, relacionada aos solutos presentes nele. As variações das sucções matriciais, na maior parte dos problemas envolvendo solos não saturados, podem ser substituídas pelas variações das sucções totais e vice-versa, sendo esta a que apresenta maior interesse para a engenharia geotécnica (FREDLUND e RAHARDJO, 1993).

A curva de retenção de água relaciona as sucções matriciais aos teores de umidade do solo, aos teores volumétricos ou ao grau de saturação, dessa forma também pode ser chamada de curva característica, curva de sucção, curva característica de umidade, curva de capilaridade $x$ saturação, entre outros. Diversos fatores influenciam na forma da curva característica, não dependendo somente da natureza do solo, como também do seu estado (distribuição granulométrica e dos poros, estrutura e mineralogia das partículas).

A obtenção da curva de retenção de um solo pode ser feita em laboratório, por meio de secagem ou molhagem. As curvas obtidas por esses processos não são coincidentes (Figura 19), e este fenômeno leva o nome de histerese. Isto implica que, para um mesmo valor de sucção, o teor de umidade no processo de secagem poderá ser maior que no processo de umedecimento, ou que, para um mesmo teor de umidade, a sucção será maior no processo de secagem, por exemplo. 
Figura 19. Curvas de retenção dos solos e histerese

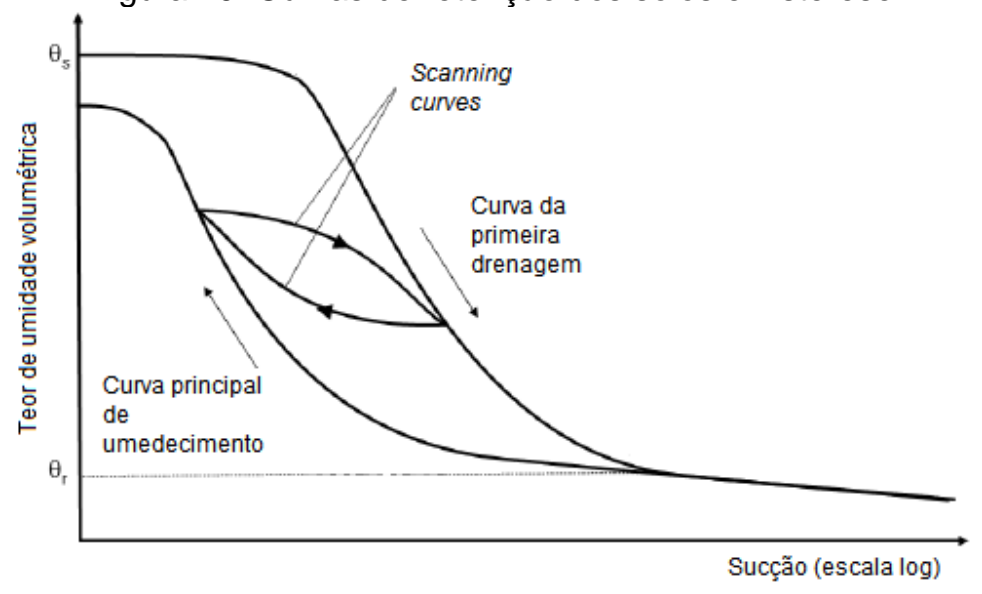

FONTE: adaptado de Toll et al., 2015.

Modelos de obtenção da curva de retenção de água

A curva de retenção é a relação entre a quantidade de água (umidade) e a sucção do solo (total, matricial ou osmótica), como mencionado anteriormente, e sua trajetória pode ser caracterizada e equacionada por diversos métodos, em campo e em laboratório (Tabela 1). A escolha pelo método a ser empregado vai depender da disponibilidade de aparatos experimentais e da faixa ampla de medida desejada, sendo esta suficiente para utilização prática (SOTO, 2004).

Tabela 1. Métodos de medição de sucção

\begin{tabular}{lll}
\hline Método & Sucção medida & Intervalo (kPa) \\
\hline Psicrômetro & Total / Osmótica & $100-8000$ \\
\hline Papel filtro & Total / Matricial & $0-29000$ \\
\hline Tensiômetro & Total / Matricial & $0-90$ \\
\hline Condutividade térmica & Matricial & $0-400$ \\
\hline Condutividade elétrica & Matricial Osmótica & $20-1500$ \\
\hline Translação de eixos & Matricial & $0-1500$ \\
\hline
\end{tabular}

FONTE: Oliveira Filho (2004)

O grau de saturação $\left(\mathrm{S}_{\mathrm{r}}\right)$, o teor de umidade gravimétrica $(w)$ e o teor de umidade volumétrica $(\theta)$ estão relacionados entre si através das seguintes correlações (Equações [12] e [9]):

$$
\theta=\frac{S_{r} \cdot e}{1+e}=S_{r} \cdot n
$$




$$
\theta=\frac{\gamma_{d} \cdot w}{\gamma_{w}}
$$

Onde: $e=$ índice de vazios;

$n=$ porosidade;

$\gamma_{d}=$ peso específico seco; e,

$\gamma_{w}=$ peso específico da água.

Existem, da mesma forma, vários modelos empíricos baseados em equações para representar a curva de retenção de água de um solo, dos quais se faz importante citar (Equações [12] a [9]):

a) Modelo de Brooks e Corey (1964)

$$
S_{e}=\frac{S-S_{r}}{1-S_{r}}=\left(\frac{\Psi_{b}}{\Psi}\right)^{\lambda}
$$

Onde: $S_{e}=$ grau de saturação efetivo;

$S=$ grau de saturação;

$S_{r}=$ grau de saturação residual;

$\Psi_{b}=$ sucção na entrada de $\operatorname{ar}\left[=\left(u_{a}-u_{w}\right) \mathrm{b}\right]$;

$\lambda$ = índice de distribuição de poros; e,

$\Psi=$ sucção.

b) Modelo de van Genuchten (1980)

$$
\begin{aligned}
\frac{\theta-\theta_{r}}{\theta_{s}-\theta_{r}} & =\left[\frac{1}{1+(\alpha . \Psi)^{n}}\right]^{m} \\
m & =1-\frac{1}{n}
\end{aligned}
$$

Onde: $\theta$ = teor de umidade volumétrico;

$\theta_{r}=$ teor de umidade volumétrico residual; 
$\theta_{s}=$ teor de umidade volumétrico saturado;

$\alpha=$ sucção de entrada de $\operatorname{ar}\left[=\left(u_{a}-u_{w}\right)\right.$ b];

$\mathrm{n}$ = inclinação da curva característica depois do ponto de entrada de ar; e, $\Psi$ = sucção. 


\section{MATERIAIS E MÉTODOS}

Este trabalho baseia-se no estudo comparativo de trechos experimentais de via permanente renovados com perfis estruturais distintos: um contendo sublastro de concreto betuminoso usinado a quente e outro, tido como referência, composto por sublastro granular de brita graduada simples. As avalições foram de cunho estrutural e geométrico "in situ" (por instrumentação e monitoramento da via). Complementarmente, foram realizados ensaios laboratoriais para análise de propriedades físicas e mecânicas dos materiais geotécnicos da subestrutura.

\subsection{Trecho experimental}

As etapas desta fase contemplam a execução, a instrumentação e as campanhas de medição "in situ" do comportamento mecânico dos trechos experimentais ao longo de suas solicitações ambientais e de tráfego. Adicionalmente foram levantados parâmetros relativos à geometria, às condições de temperatura da mistura asfáltica e de umidade do subleito. Conforme será descrito a seguir, o trecho se localiza em uma via permanente operada pela empresa MRS, na região da Baixada Santista (a cerca de $90 \mathrm{~km}$ da capital paulista). As atividades realizadas e resultados esperados estão esquematizados na Figura 20.

Figura 20. Fluxograma de atividades de avaliação

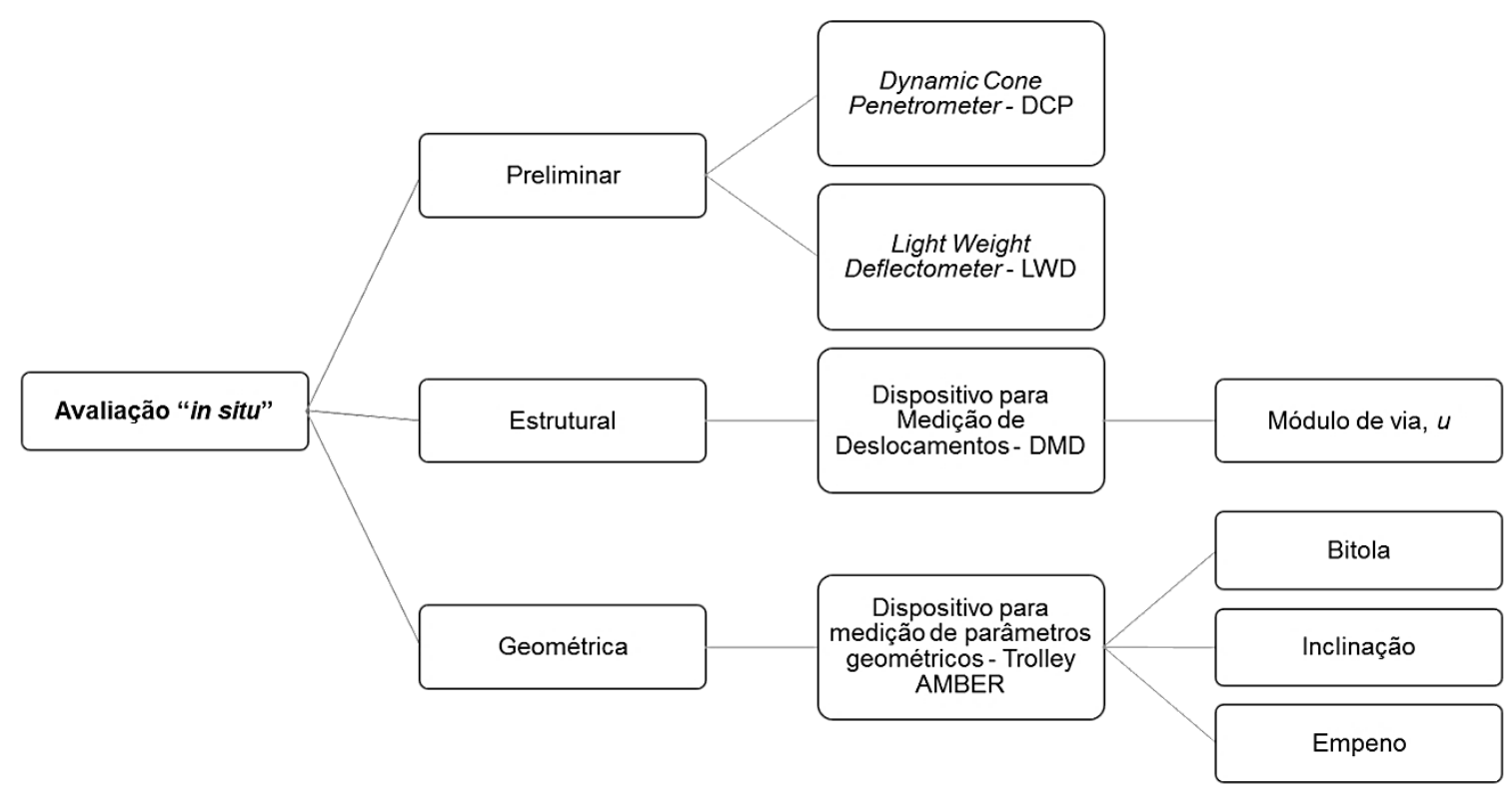




\subsubsection{Localização}

A MRS, fundada em 1996, atua como operadora logística da malha ferroviária de carga que interliga os estados de Minas Gerais, Rio de Janeiro e São Paulo, na região sudeste do Brasil (Figura 21). Segundo dados institucionais, a mesma administra um total de $1.643 \mathrm{~km}$ de ferrovia, por onde cerca de um terço de toda a produção nacional transportada por trens circula. A companhia também é responsável pelo Sistema Cremalheira, que transita entre o desnível da Serra do Mar, interligando a Vila de Paranapiacaba, na Região Metropolitana de São Paulo, até Cubatão, na Baixada Santista. Neste segmento da via, as locomotivas vencem inclinações longitudinais de até $10 \%$, em um trajeto de quase oito quilômetros de extensão, usando um conjunto de rodas dentadas e um sistema adicional de tração e frenagem-motor, único no mundo (MRS, 2018).

Figura 21. Malha ferroviária sob gestão da MRS Logística S.A.

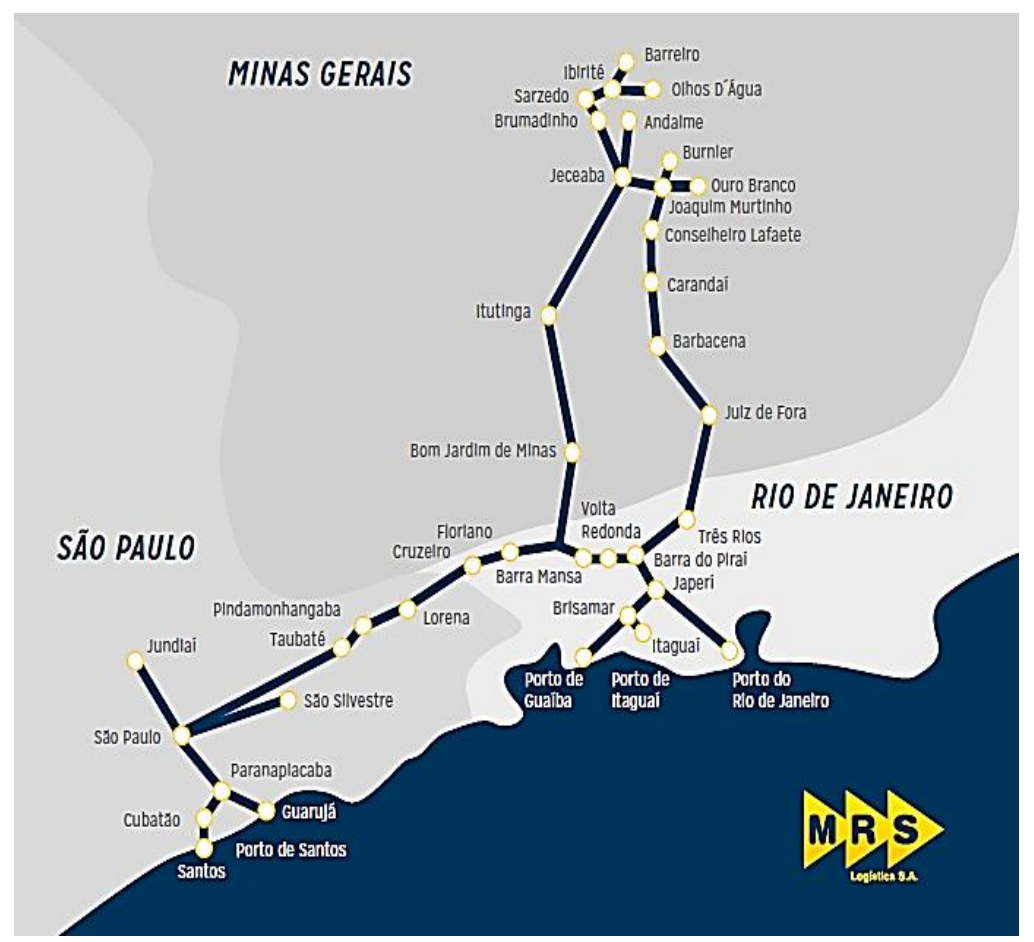

FONTE: https://www.mrs.com.br/empresa/ferrovia-frota/, acesso em 13 de fevereiro de 2018.

A via permanente lastrada que liga o pátio de Piaçaguera a Raiz da Serra (PG-RS), no município de Cubatão (São Paulo), integra a malha operada atualmente pela MRS. A linha possui bitola larga (1.600 mm), trilho TR57 (AREMA), dormentes de madeira $(2,80 \times 0,24 \times 0,17 \mathrm{~m})$ e fixações elásticas do tipo Deenik em toda a extensão estudada 
(Figura 22). Durante o ano de 2017, o tráfego solicitante nessa seção foi de 11 milhões de toneladas brutas transportadas (MTBT), dividido igualmente entre duas linhas (1 e 2), e registrado mensalmente como mostra a Tabela 2. A carga por eixo média da via é de 27,5 toneladas, sendo cargas prioritariamente transportadas: contêineres, siderúrgicos, cimento, bauxita, agrícolas, coque, carvão e minério de ferro.

Tabela 2. Tráfego solicitante nas linhas 1 e 2 da via PG-RS no ano de 2017

\begin{tabular}{|c|c|c|c|c|c|c|c|c|c|c|c|}
\hline & Jan/17 & Fev/17 & Mar/17 & Abr/17 & Maio/17 & Jun/17 Jul/17 & Ago/17 & Set/17 & Out/17 & Nov/17 & Dez/17 \\
\hline MTBT & 0,867 & 0,817 & 0,959 & 0,939 & 0,940 & $\begin{array}{ll}0,805 & 0,919 \\
\end{array}$ & 1,034 & 0,980 & 1,017 & 0,987 & 1,011 \\
\hline Total & & & & & & 11,275 & & & & & \\
\hline
\end{tabular}

Figura 22. Localização do trecho experimental

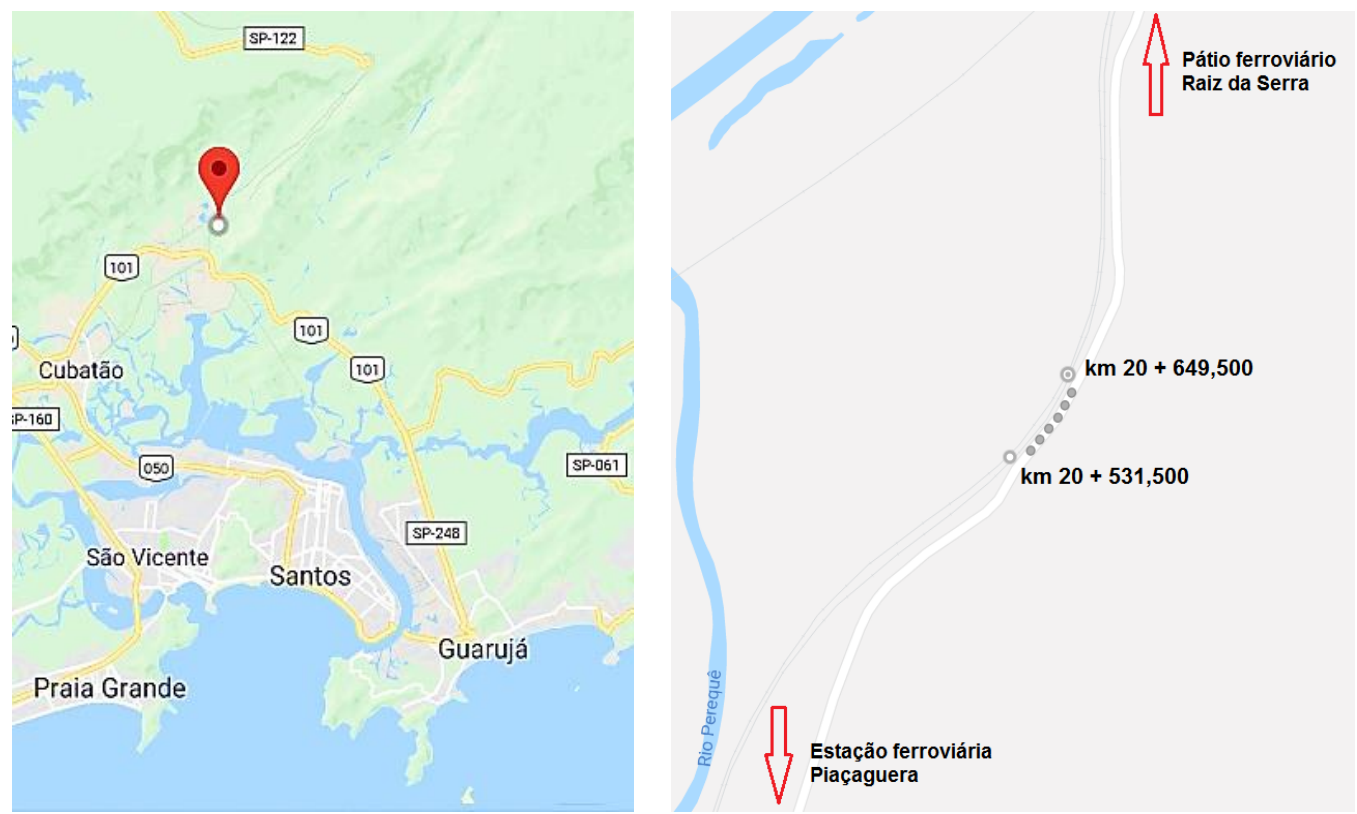

FONTE: https://www.google.com.br/maps, acesso em 29 de janeiro de 2018.

O perfil atual da subestrutura da via permanente, com construção que data da década de 80 , constitui-se por uma camada de lastro de rocha britada de cerca de $200 \mathrm{~mm}$ de espessura, diretamente assentada sobre o subleito. A incerteza quanto à espessura desta camada ao longo da extensão longitudinal da via deve-se à sua condição bastante colmatada, como pode ser observada na Figura 23, tornando difícil a delimitação precisa entre as camadas de lastro e de subleito. 
Figura 23. (a) Cava de inspeção do pavimento ferroviário e (b) Detalhe do lastro colmatado

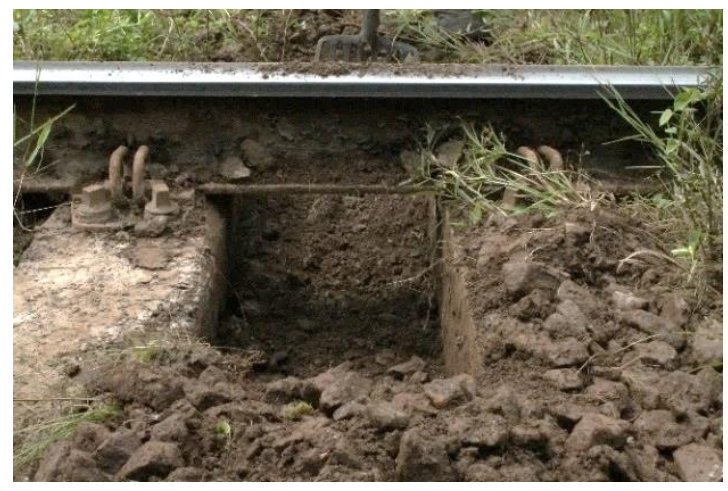

(a)

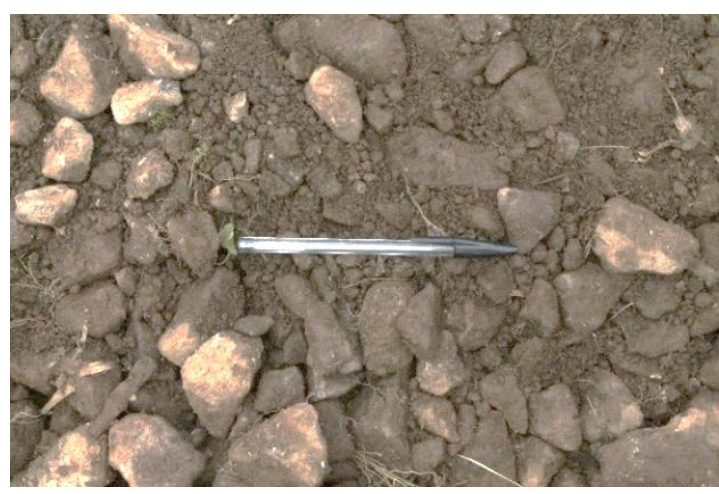

(b)

A região onde se encontra o ramal estudado é composta por aterro sobre depósitos de solo mole (mangue: sedimentos caracterizados como tipo vasa/lama) e possui nível d'água elevado. A baixa resistência ao cisalhamento e a alta compressibilidade deste tipo de solo constituem-se como características desfavoráveis para longevidade da via permanente, uma vez que o recalque diferencial da plataforma afeta significativamente os parâmetros geométricos da ferrovia e acelera o desgaste de seus componentes, devendo ser evitado. A região possui clima com temperatura e umidade elevadas durante todo o ano, elevada pluviosidade durante o verão e invernos secos.

Como uma primeira abordagem do tema em pesquisas nacionais contendo trechos experimentais, buscou-se avaliar o comportamento mecânico de um segmento de via permanente com camada de sublastro betuminoso de forma comparativa a um segmento com camada de sublastro granular. Cientes de que tal configuração tida como referência não representa a condição real da totalidade da malha na região da Baixada Santista (em sua grande maioria, sem sublastro), esforços também foram feitos para que medidas de deslocamento e de geometria fossem tomadas em seções adjacentes que não sofreram alterações na sua infraestrutura.

Ambos os trechos experimentais foram executados no primeiro semestre de 2017 , e constituíram-se como intervenções de renovação e reabilitação de via permanente. A fim de se manterem as condições de tráfego, configurações climáticas e ambientais similares, os segmentos em estudo são subjacentes, possuem velocidade média de operação de $20 \mathrm{~km} / \mathrm{h}$ e integram um trecho em curva. 


\subsubsection{Ensaios preliminares "in situ"}

A caracterização da condição do subleito "in situ" se fez necessária frente à verificação da indispensabilidade ou não de tratamento superficial ou reforço do mesmo. A execução da camada de sublastro betuminoso requer o emprego de maquinário de grande porte e circulação de diversos veículos durante o processo construtivo, o que gerou uma preocupação quanto à capacidade de suporte da plataforma para resistir a tamanhos esforços ainda na etapa de construção.

Dessa forma, ensaios semidestrutivos (Dynamic Cone Penetrometer - DCP) e não destrutivos (Light Weight Deflectometer - LWD) foram realizados no $\mathrm{km} 20+600 \mathrm{da}$ linha 2 PG-RS (Figura 24) a $350 \mathrm{~mm}$ abaixo do bordo inferior do dormente, profundidade de corte na qual viria a ser assentada a camada de mistura asfáltica para compor o sublastro betuminoso. O ensaio de DCP foi realizado de acordo com a norma ASTM D6951/6951M-09, para se determinar a capacidade de carga do subleito, correlacionando os valores obtidos com valores de California Bearing Ratio (CBR); enquanto o de LWD foi realizado de acordo com a norma ASTM E258307(2015), para se determinar a rigidez da camada de subleito. Amostras de solo foram coletadas e encaminhadas ao Laboratório de Tecnologia da Pavimentação da Universidade de São Paulo, a fim de que fossem realizadas as devidas etapas de caracterização física e mecânica do mesmo.

Figura 24. Ensaio de DCP e LWD no km 20 + 600 da linha 2 PG-RS
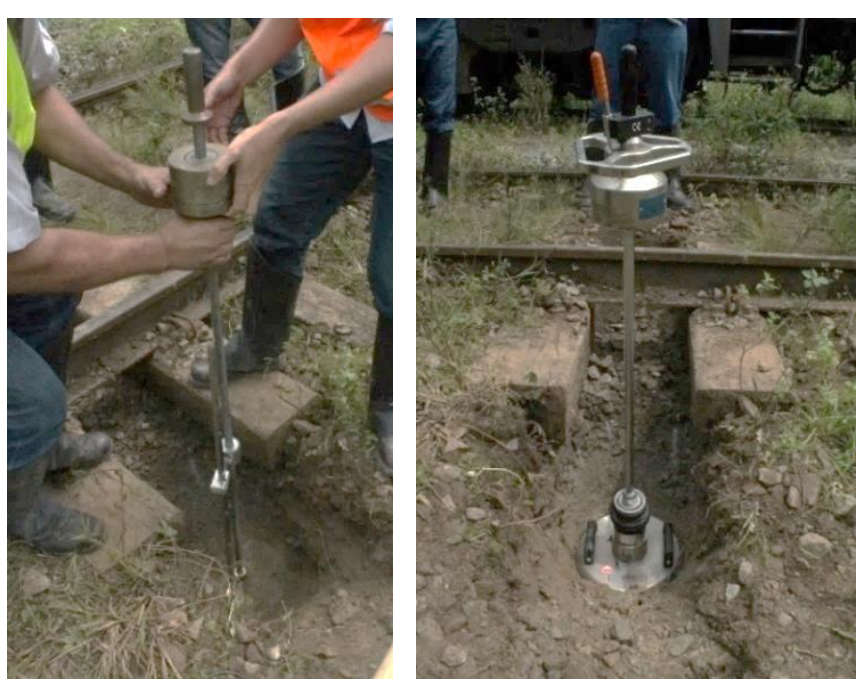


\subsubsection{Dimensionamento das camadas}

Em concordância com resultados de simulações numéricas realizadas por Rangel et al. (2015), decidiu-se por executar uma camada de sublastro betuminoso de $125 \mathrm{~mm}$ de espessura. Tal valor encontra-se dentro da faixa aceitável recomendada por Teixeira et al. (2006), Rose e Bryson (2009), Albanat et al. (2011) e Di Mino et al. (2012).

A mistura asfáltica empregada constitui-se como um Concreto Betuminoso Usinado a Quente (CBUQ) e foi dosada em laboratório fazendo-se uso da metodologia Marshall. O agregado empregado é de origem granítica e o ligante asfáltico é um CAP 50/70, classificado por penetração segundo a norma NBR 6576:2007.

Seguindo-se recomendações encontradas na literatura relativas à distribuição granulométrica dos agregados empregada em misturas asfálticas para sublastro betuminoso na Itália e nos Estados Unidos, obteve-se uma curva granulométrica que se adequa aos limites da Faixa B da norma DNIT 031/2004 para pavimentos rodoviários. A mesma pode ser visualizada na Figura 25 e possui $2 \%$ de fíler calcário do tipo cal hidratada calcítica $(\mathrm{CH}-1)$ em sua composição, para melhorar a adesividade da matriz granulométrica. O teor de ligante de projeto encontrado foi de $4,4 \%$ e 0 volume de vazios de 3,7\%, ambos dentro dos limites recomendados para aplicação em sublastro betuminoso (item 2.2.2).

Figura 25. Distribuição granulométrica dos agregados para sublastro betuminoso

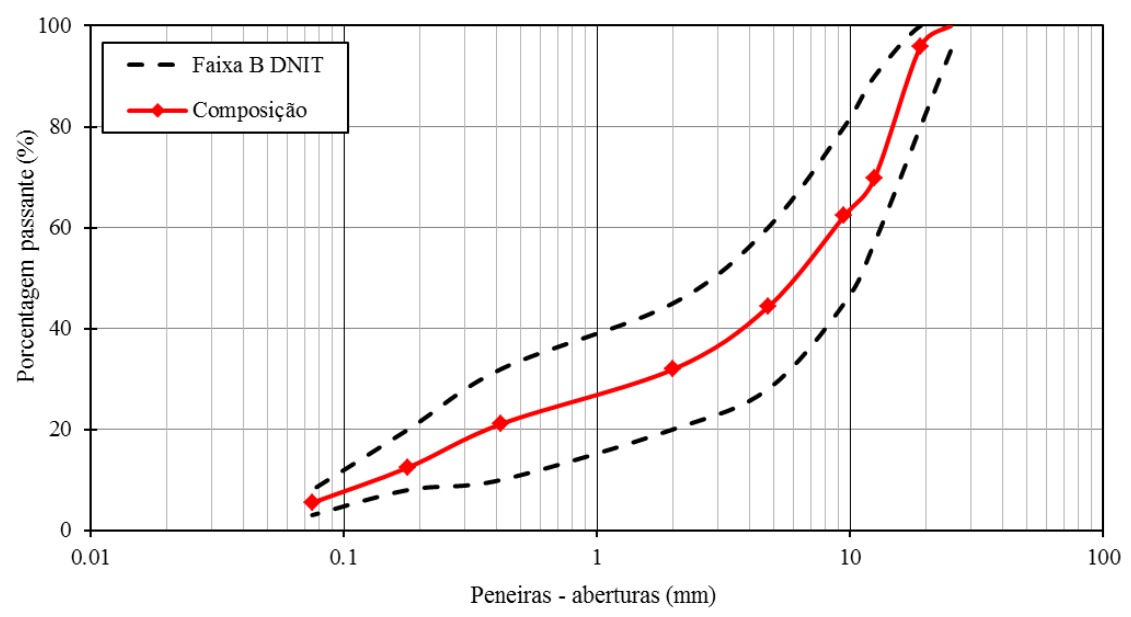


O dimensionamento da camada de sublastro granular do trecho de referência levou em consideração critérios de distribuição granulométrica empregados em camadas granulares que desempenham função de filtro. Selig e Waters (1994) citam estudos desenvolvidos por Terzaghi e Casagrande, baseados em trabalhos de Cedergren (1989), que definem limites para valores de massa de parcelas de materiais granulares que venham a compor camadas drenantes, de acordo com 0 diâmetro das partículas que integram tanto a camada a ser protegida quanto a camada de filtro (Equações [105] e [116]):

$$
\begin{gathered}
D_{15}(\text { camada de filtro }) \leq 5 D_{85}(\text { camada a ser protegida }) \\
D_{50}(\text { camada de filtro }) \leq 25 D_{50}(\text { camada a ser protegida })
\end{gathered}
$$

Onde: $D_{n}$ é a abertura da malha pela qual passam $\mathrm{n} \%$ em massa do material.

Baseando-se neste critério e de posse dos resultados da análise granulométrica do solo do subleito da região, obteve-se a curva de distribuição mostrada na Figura 26. Esta composição encontra-se dentro da tolerância da Faixa C de Brita Graduada segundo a Especificação Técnica PE-D00/008 da DERSA (Sub-base ou base de brita graduada). Os agregados são de mesma origem daqueles empregados para compor a mistura asfáltica e a espessura de projeto da camada é de $100 \mathrm{~mm}$.

Figura 26. Distribuição granulométrica de agregados para sublastro granular

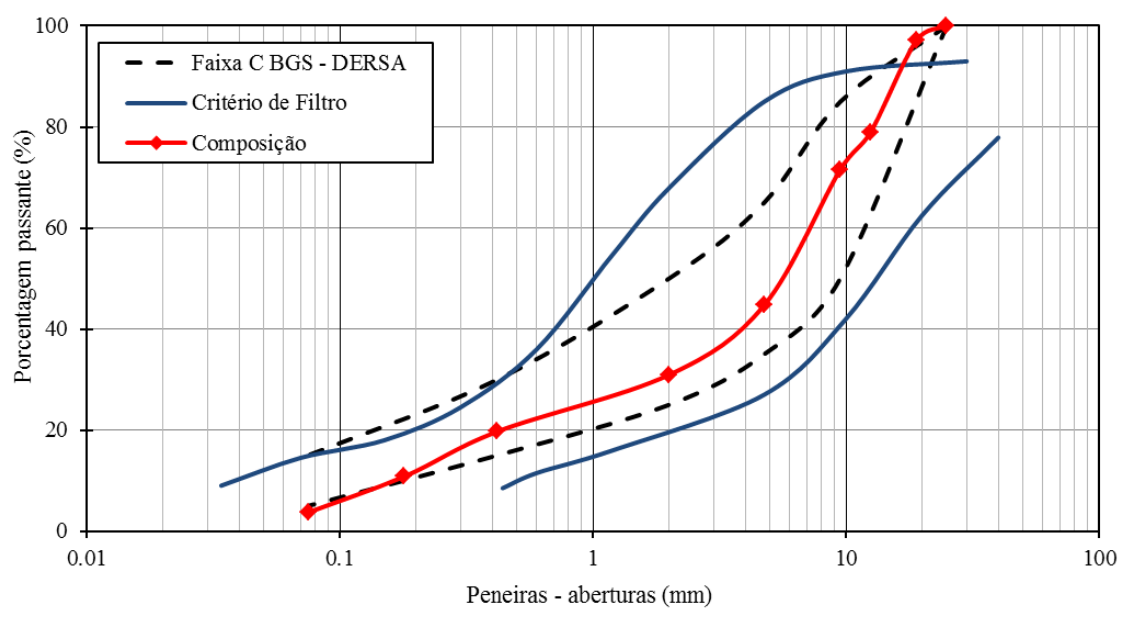


A camada de lastro ficou estabelecida em $300 \mathrm{~mm}$ de espessura em ambos os trechos, a medir do bordo inferior do dormente ao topo do sublastro; os demais componentes da superestrutura também possuem as mesmas características nas duas seções, assim como a camada de subleito. Na Figura 27, o trecho I corresponde à estrutura contendo sublastro betuminoso, enquanto o trecho II corresponde à estrutura contendo sublastro granular de brita graduada simples.

Figura 27. Seções de projeto dos trechos experimentais (fora de escala)

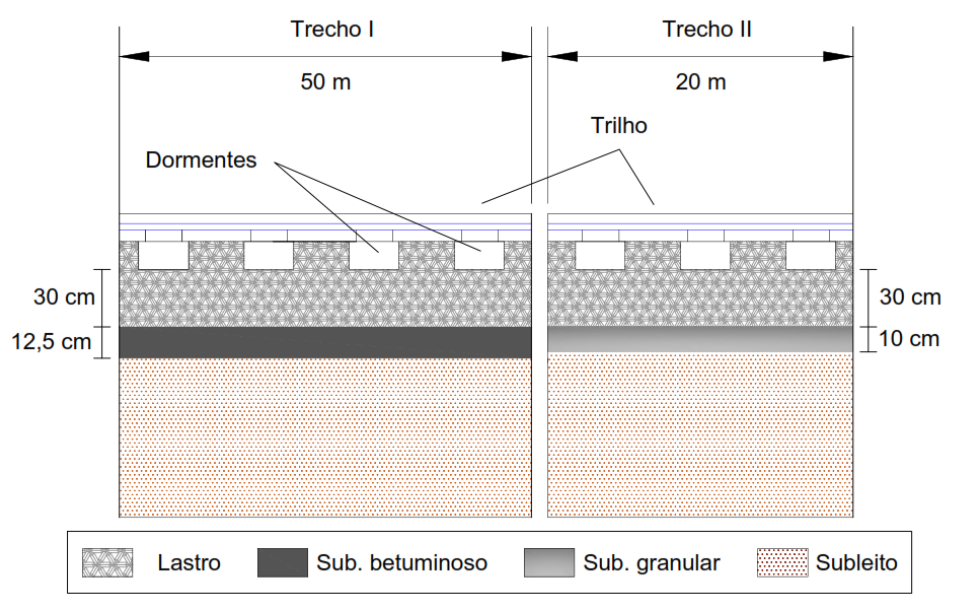

\subsubsection{Processo executivo}

A execução do trecho com camada de sublastro betuminoso ocorreu em 10 de abril de 2017, na linha 2 da via permanente PG-RS. A operação teve de ser demasiadamente planejada, uma vez que o acesso ao local era restrito, assim como o intervalo de tempo disponível para a paralisação do tráfego para renovação da subestrutura. Fatores tidos como críticos foram decididos de forma conjunta, alinhando-se diversos setores da empresa, prestadores de serviço e pesquisadores. A usina fornecedora de mistura asfáltica localizava-se a uma distância média de transporte aceitável em relação ao local da obra $(4,5 \mathrm{~km})$, a fim de se assegurar que não haveria perda da temperatura entre os processos de usinagem e de compactação do material; enquanto os equipamentos utilizados na execução possuíam características específicas para que se pudessem vencer as limitações de acesso ao local, composto por uma única via lateral de baixo volume de tráfego e uma ponte de 2,6 m de largura. 
Outros pontos importantes referiam-se ao local de bota-fora dos materiais que seriam retirados da via. A MRS fez uso da paralisação semanal de manutenção do seu sistema cremalheira e disponibilizou, a princípio, 12h de liberação da linha para execução do trecho experimental. Tempo este que deveria contemplar, inclusive, uma operação mecanizada de socaria para realinhamento da geometria da via ao final da construção.

O início da construção propriamente dito deu-se com a retirada da superestrutura ferroviária. As fixações elásticas foram manualmente afrouxadas, procedeu-se o corte dos trilhos e à disposição dos mesmos na região de entrevias. Na sequência, os dormentes de madeira foram extraídos da camada de lastro, nitidamente colmatada, e encaminhados para descarte (Figura 28).

Figura 28. (a) Corte dos trilhos e (b) Retirada de dormentes

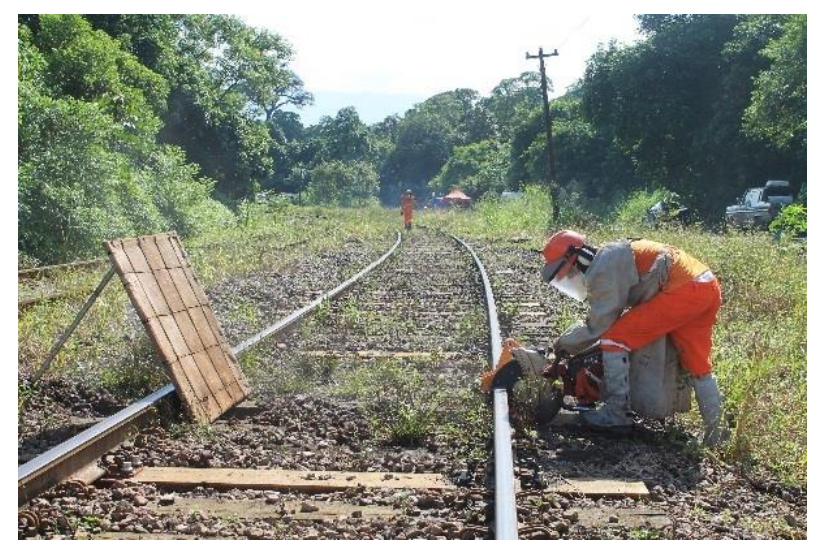

(a)

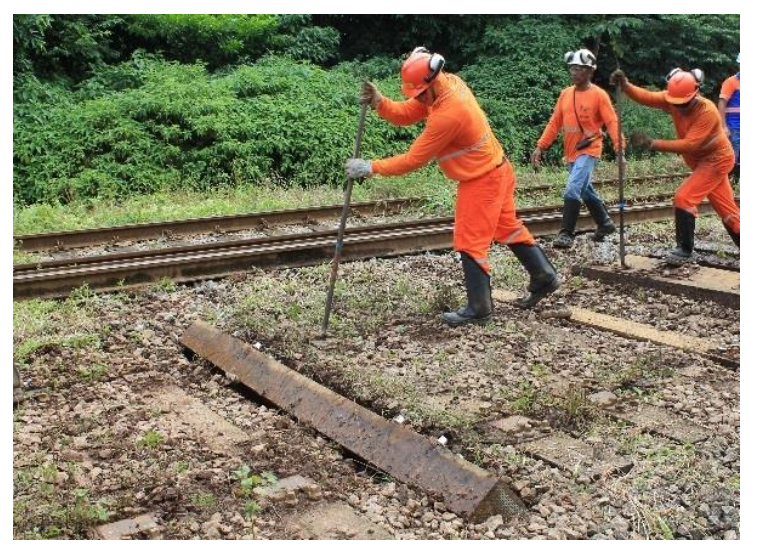

(b)

Com o intuito de se possibilitar o acesso de veículos ao eixo da via, foi necessário o remanejamento prévio de uma parcela da camada de lastro (região do ombro) para os dispositivos de drenagem localizados entre a via de acesso rodoviário e a via permanente. As valas de concreto que margeiam toda a extensão do trecho estudado foram temporariamente preenchidas e compactadas com uma mistura de agregado e solo para facilitar o trânsito, e passaram por um processo de restauro e limpeza logo após a renovação da via. Este procedimento de realocação de material facilitou o corte da subestrutura à profundidade desejada (Figura 29), pois reduziu a quantidade de material que foi retirado e transportado para a área de bota-fora. 
Figura 29. Corte da subestrutura para implantação de sublastro betuminoso
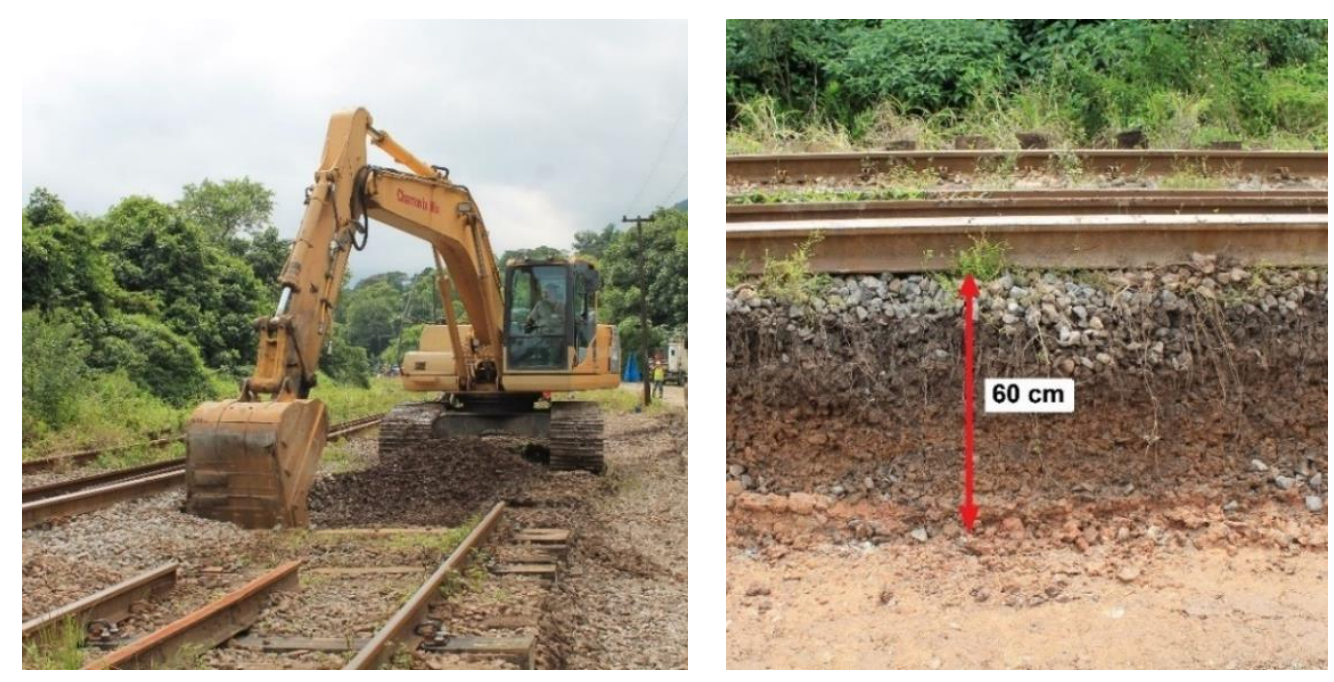

Uma vez exposta a plataforma, amostras de solo foram retiradas e reservadas para obtenção do teor de umidade de campo, e uma delgada camada composta por agregados do lastro retirado foi reposta e compactada, sem que fossem realizados procedimentos de beneficiamento do material. $O$ processo construtivo do segmento com sublastro betuminoso requer a circulação de maquinário de grande porte na plataforma, exigindo uma superfície resistente e uniforme para ida e vinda de veículos. Dessa maneira, procedeu-se a este "agulhamento" com camada monogranular de lastro reaproveitado na superfície do subleito, seguido de uma imprimação com emulsão do tipo cura rápida (CR-1C) a uma taxa de $0,9 \mathrm{~L} / \mathrm{m}^{2}$, feita com caneta. $A$ camada de mistura asfáltica foi esparramada e compactada em duas etapas, tendo a primeira $60 \mathrm{~mm}$ (Figura 30). 
Figura 30. Execução da primeira camada de mistura asfáltica
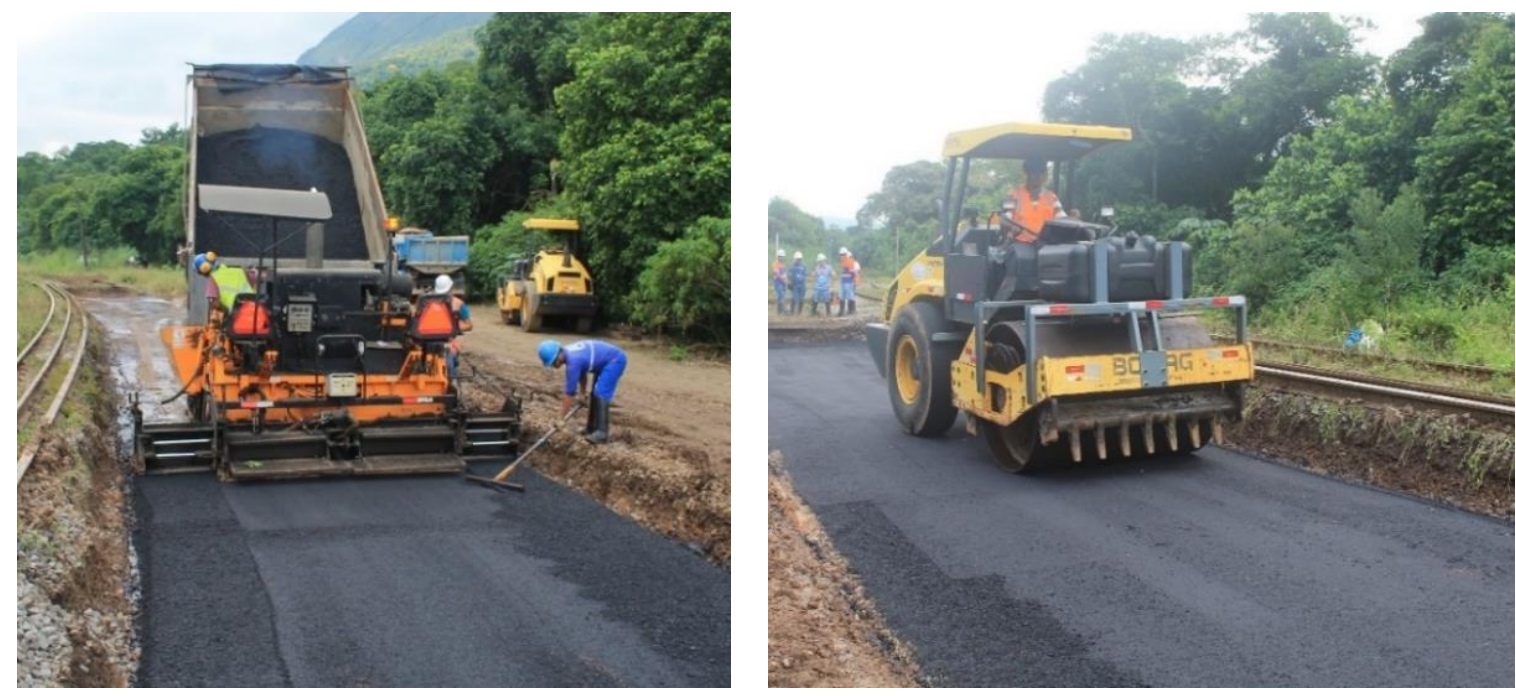

Em seguida, procedeu-se ao espalhamento e compactação da segunda camada de mistura asfáltica, dessa vez com $65 \mathrm{~mm}$ de espessura. Como observado na Figura 30 , os equipamentos utilizados foram aqueles tradicionalmente empregados em pavimentação rodoviária: vibroacabadora e rolo compactador vibratório liso. Amostras de mistura asfáltica foram recolhidas diretamente do caminhão e reservadas para a devida caracterização do material em laboratório.

Imediatamente após a compactação da segunda camada de mistura asfáltica, uma nova camada de material de lastro foi despejada (Figura 31), facilitando a alocação dos dormentes de madeira nas dimensões padrão para bitola larga, já emplacados com placa de apoio de 4 furos para a fixação. Os trilhos foram então reinseridos na via e anexados por talas de junção temporárias. 
Figura 31. (a) Despejo da primeira camada de lastro e (b) Disposição de dormentes novos

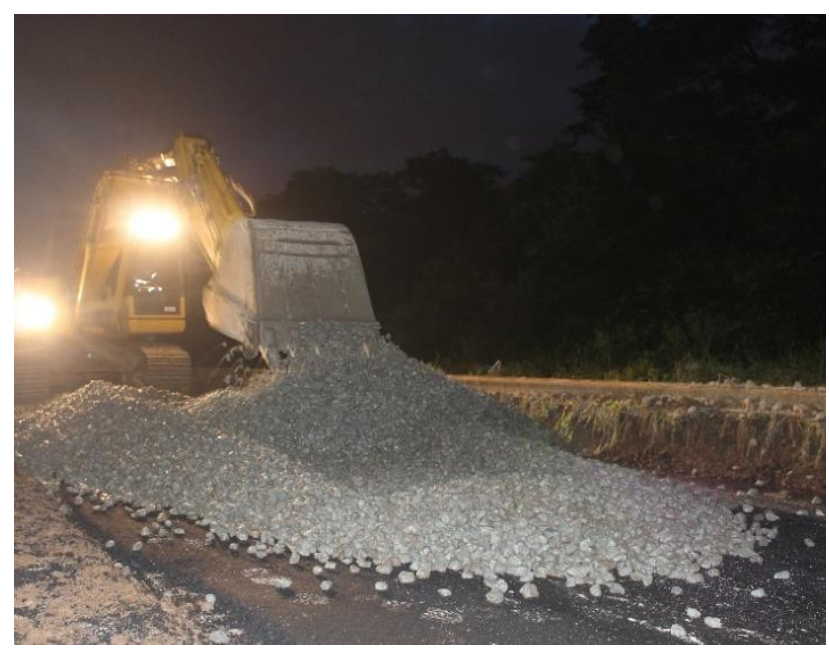

(a)

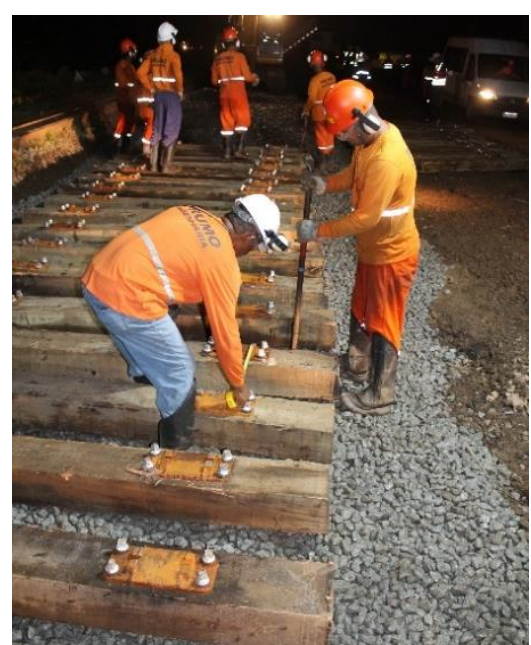

(b)

Repostos todos os elementos da superestrutura (dormentes, fixações e trilhos), uma nova quantia de material de lastro foi despejada na linha para que fosse atingida a espessura de $300 \mathrm{~mm}$ da camada e preenchidos os vazios entre os dormentes. Nesta ocasião, deu-se início a solicitação da via por uma composição carregada, após aproximadamente $15 \mathrm{~h}$ de interrupção do tráfego.

A última etapa da execução do trecho experimental com sublastro betuminoso consistiu na correção geométrica da via através de socaria mecanizada. O processo consistiu em uma primeira viagem para leitura de defeitos geométricos da linha recémconstruída, seguida de outra para ajuste da mesma a parâmetros preestabelecidos de superelevação, nivelamento longitudinal e transversal.

Em 8 de maio de 2017, aproximadamente um mês após a execução do trecho com sublastro betuminoso, deu-se a execução do trecho experimental com sublastro granular (referência). As etapas construtivas seguiram a mesma metodologia realizada para o primeiro trecho, à exceção somente das atividades relacionadas à mistura asfáltica, neste momento substituída por uma camada de brita graduada simples (BGS). 


\subsubsection{Instrumentação}

Durante a renovação de ambas as seções, equipamentos de medição de parâmetros em campo foram inseridos, a diferentes profundidades, e com finalidades diversas. esquema de instrumentação e o detalhamento de cada sensor podem ser encontrados nos parágrafos que se sucedem. Anteriormente à execução dos trechos experimentais, realizou-se um levantamento topográfico para se determinarem as localizações exatas de inserção dos sensores, uma vez que se tornaria inviável tomar como referência marcações na grade ferroviária, retirada para possibilitar a compactação da camada betuminosa e de BGS.

\section{Células de pressão total}

A inserção de células de pressão total (Figura 32) destinou-se à medição das tensões atuantes nas interfaces dormente/lastro e sublastro/subleito, quando da passagem de trens na via permanente. Cada célula foi confeccionada em aço inox 304, possuía diâmetro de $200 \mathrm{~mm}$ e espessura de 12 mm, transdutor de pressão piezoresistivo, alimentação 10 Vcc e saída em corrente de 4 a 20 mA.

Figura 32. Célula de pressão total de 200 kPa e detalhe da sua colocação no trecho com sublastro betuminoso
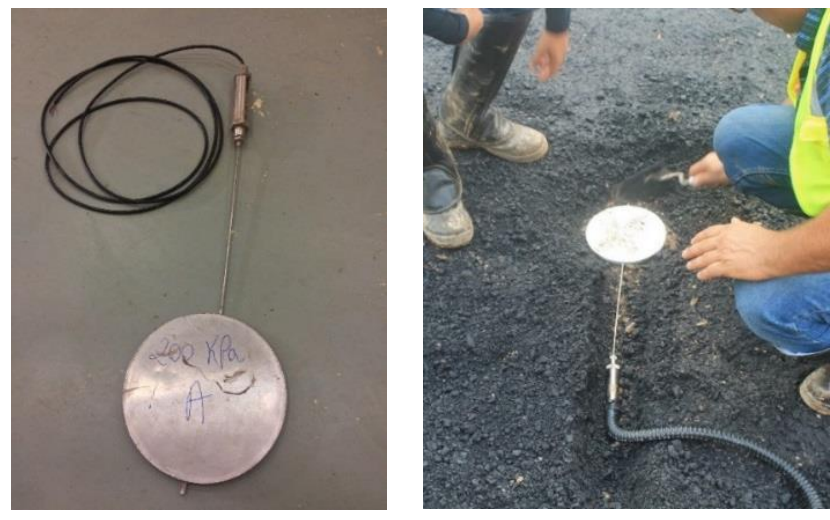

As células inseridas na interface dormente/lastro possuíam capacidade de $1.000 \mathrm{kPa}$ e as da interface sublastro/subleito $200 \mathrm{kPa}$. Todas as quatro células inseridas foram locadas no eixo da via, diretamente abaixo da interface trilho/dormente, como visto no 
esquema da Figura 33, e passaram por um processo de calibração em laboratório antes de serem levadas a campo.

Figura 33. Corte transversal com posicionamento das células de pressão (fora de escala)
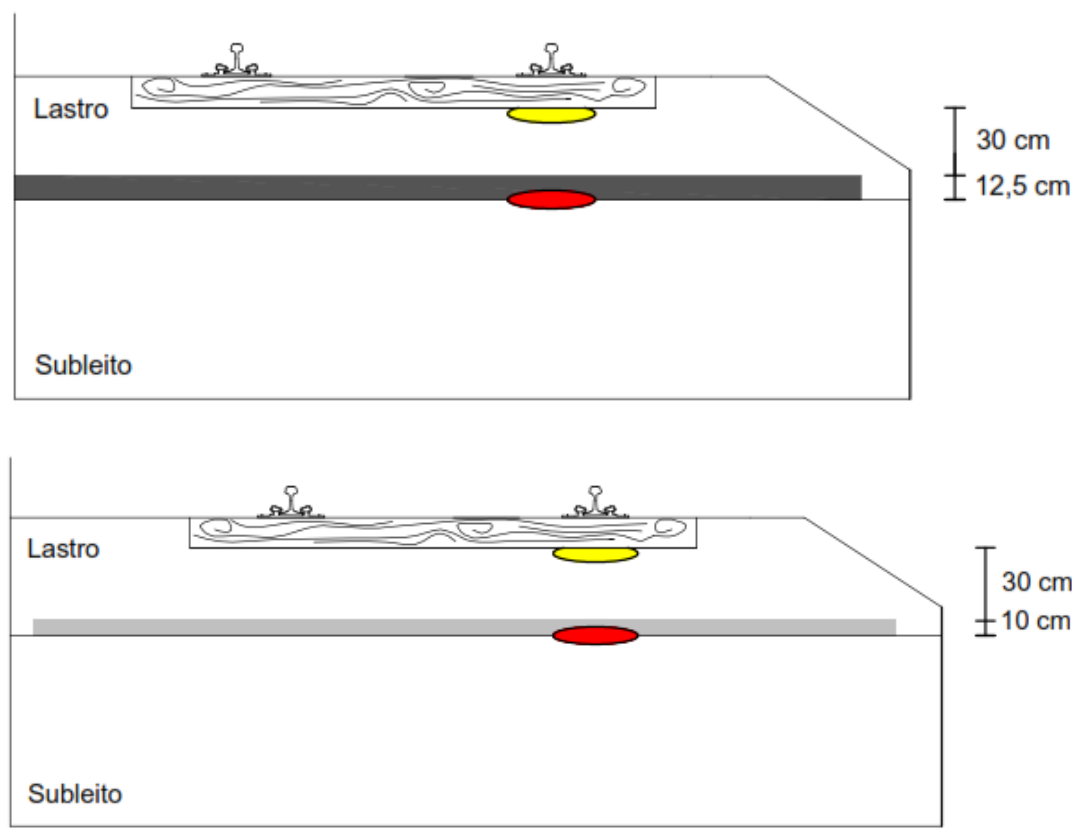

Sensores de temperatura

Cinco termopares (Figura 34) foram instalados na via em questão para medidas de temperatura: três no trecho com sublastro betuminoso, a fim de se verificar o gradiente térmico atuante na mistura asfáltica nas direções vertical e transversal, tendo em vista o comportamento termosuscetível desta; e dois no trecho com sublastro granular, também buscando-se verificar a variação de temperatura na direção transversal, na interface sublastro/subleito (Figura 35) 
Figura 34. Termopar e detalhe da sua colocação no trecho com sublastro betuminoso
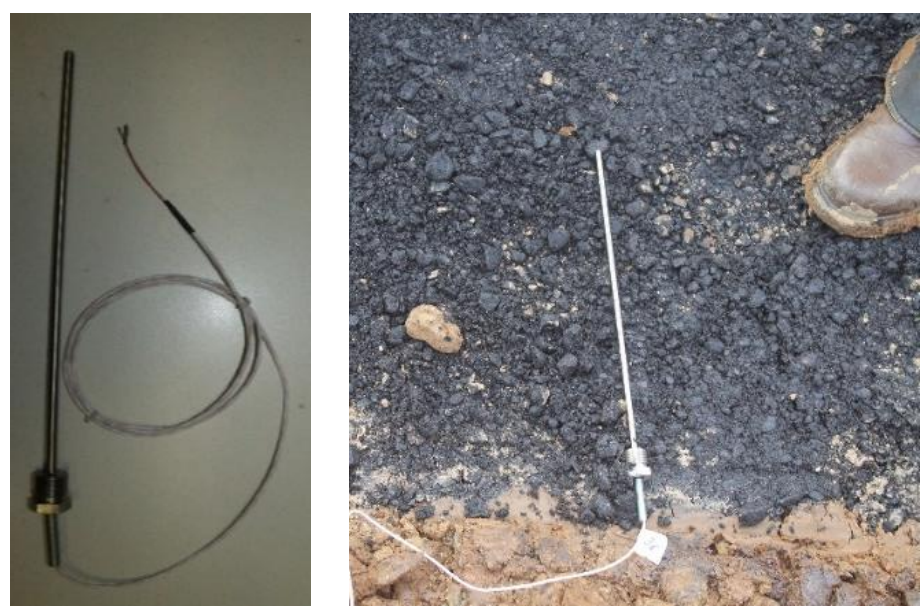

Figura 35. Corte transversal com posicionamento dos termopares (fora de escala)
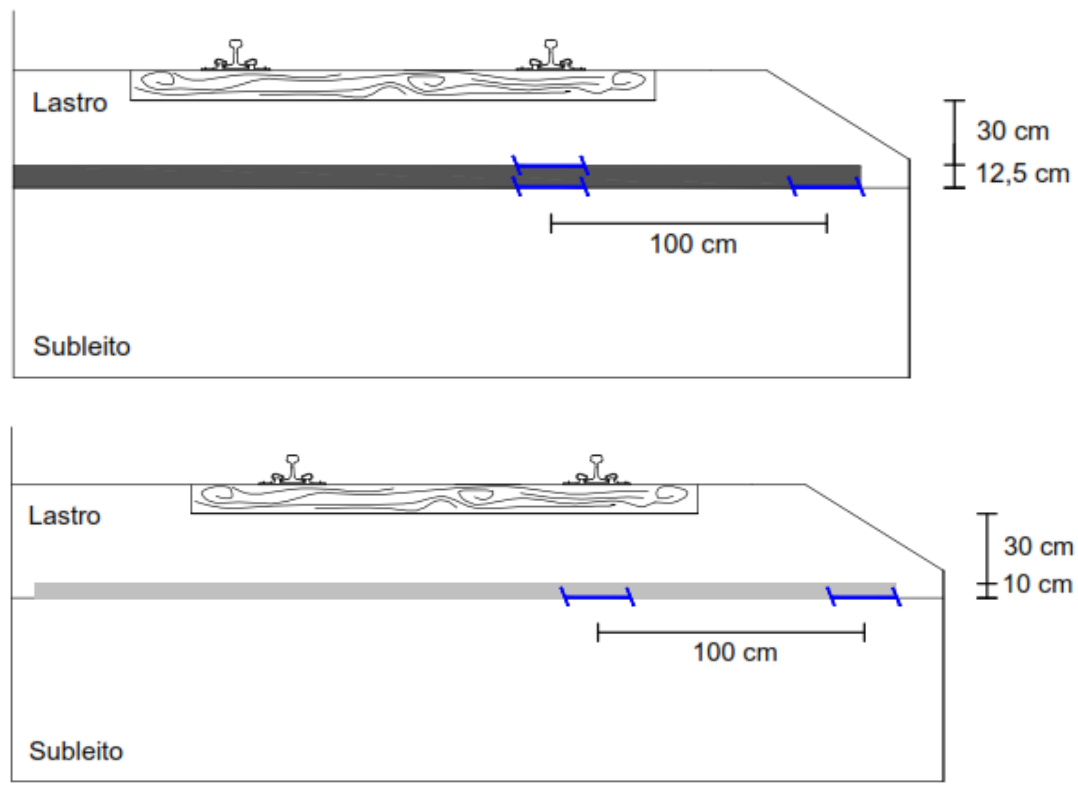
$\longmapsto$ Termopar
Sublastro betuminoso
Sublastro granular

Sensores de sucção

O sensor de resistência elétrica da marca WATERMARK (Figura 36) consiste em um par de eletrodos altamente resistentes à corrosão, que foram inseridos dentro de uma matriz granular, com função de medir valores de resistência quando correntes são aplicadas. O sensor correlaciona, então, a resistência medida a valores de tensão de água do solo, em kilopascal ( $\mathrm{kPa}$ ). A escala fornecida pelo próprio fabricante indica que valores entre 0 e $10 \mathrm{kPa}$ caracterizam um solo em condição saturada, e entre 100 
e $200 \mathrm{kPa}$ caracterizam um solo em condição seca. Foram inseridos doze sensores a diferentes profundidades na camada de subleito das duas seções estudadas (Figura 37).

Figura 36. (a) Sensores de sucção em processo de saturação, (b) Detalhe da sua instalação no trecho e (c) Dispositivo para aquisição de dados

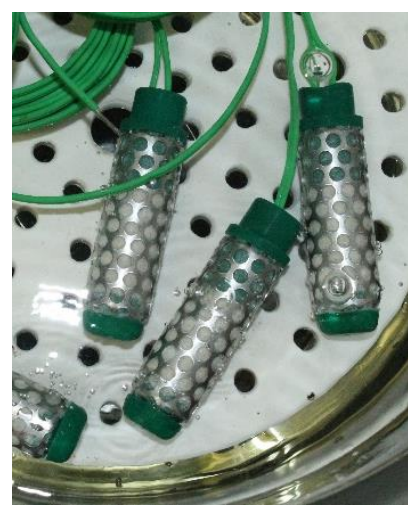

(a)

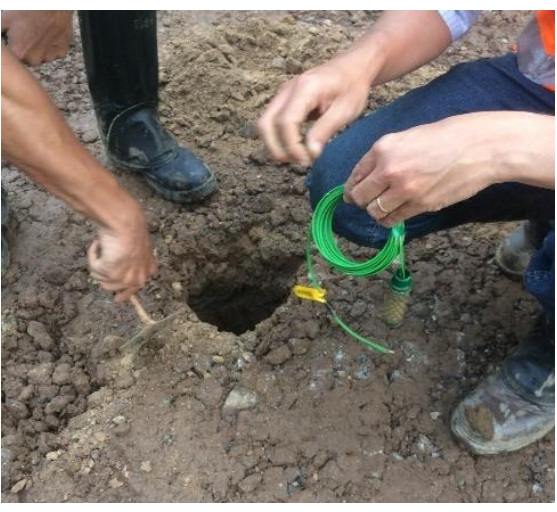

(b)

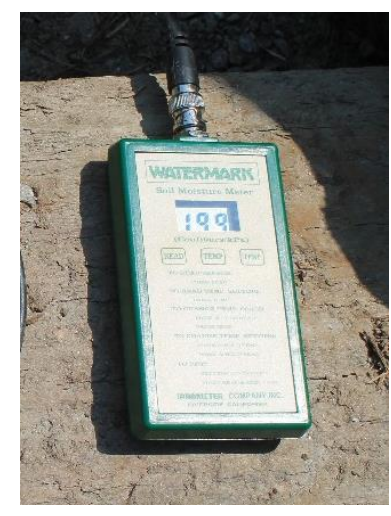

(c)

Figura 37. Corte transversal com posicionamento dos sensores de sucção (fora de escala)
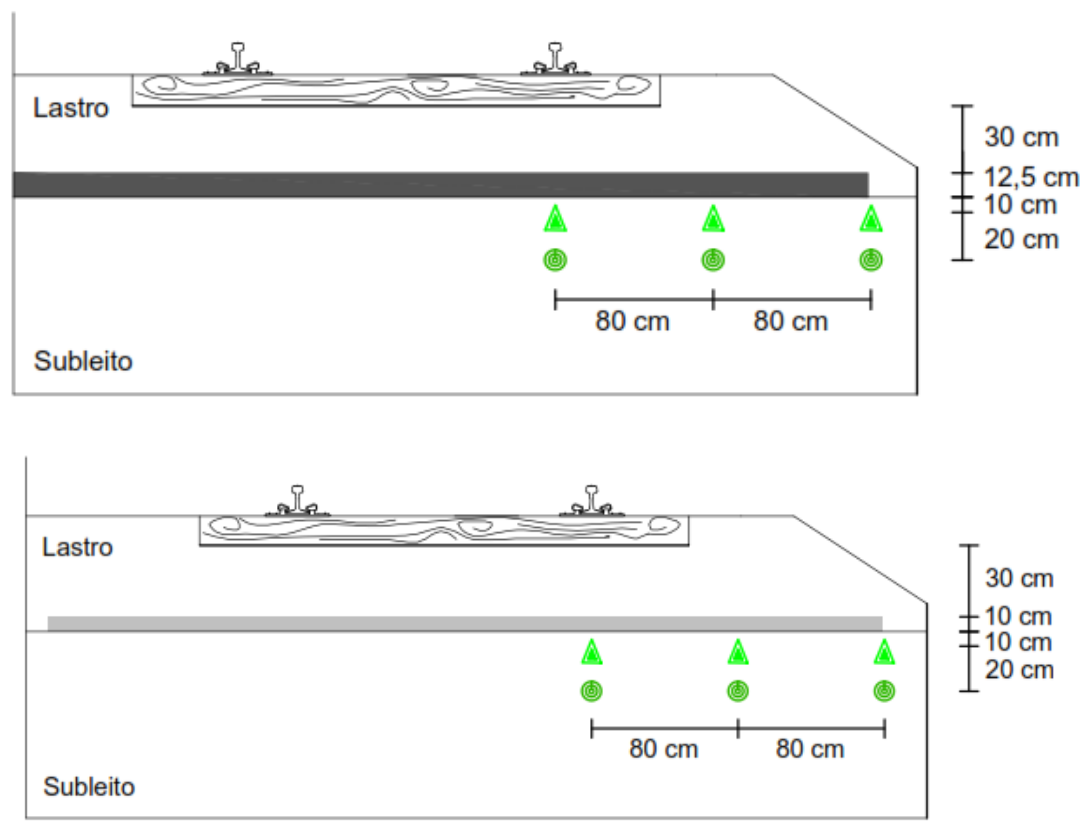


\subsubsection{Medidas da resposta mecânica e geométrica da via}

Campanhas de medição de parâmetros de cunho mecânico e geométrico foram realizadas ao longo do tempo, considerando-se o acúmulo de carga e as variações climáticas do local. Somados aos valores obtidos por meio dos sensores de sucção, temperatura e pressão instalados nos trechos, medidas de deslocamento dinâmico e de parâmetros geométricos foram realizadas em ambas as seções renovadas e em um trecho sequencial sem renovação para fins de comparação.

\section{Dispositivo para Medição de Deslocamentos}

As medidas de deslocamento vertical (no patim do trilho) foram realizadas em três pontos da via: trecho com sublastro betuminoso, trecho com sublastro granular e trecho sem intervenção. O equipamento utilizado foi desenvolvido pelo Laboratório de Tecnologia de Pavimentação da Escola Politécnica da Universidade de São Paulo (LTP-EPUSP) e é constituído por perfis de alumínio com elevada rigidez e sensores do tipo LVDTs nas suas extremidades (Figura 38).

Figura 38. Dispositivo para Medição de Deslocamentos e detalhe do LVDT no patim do trilho
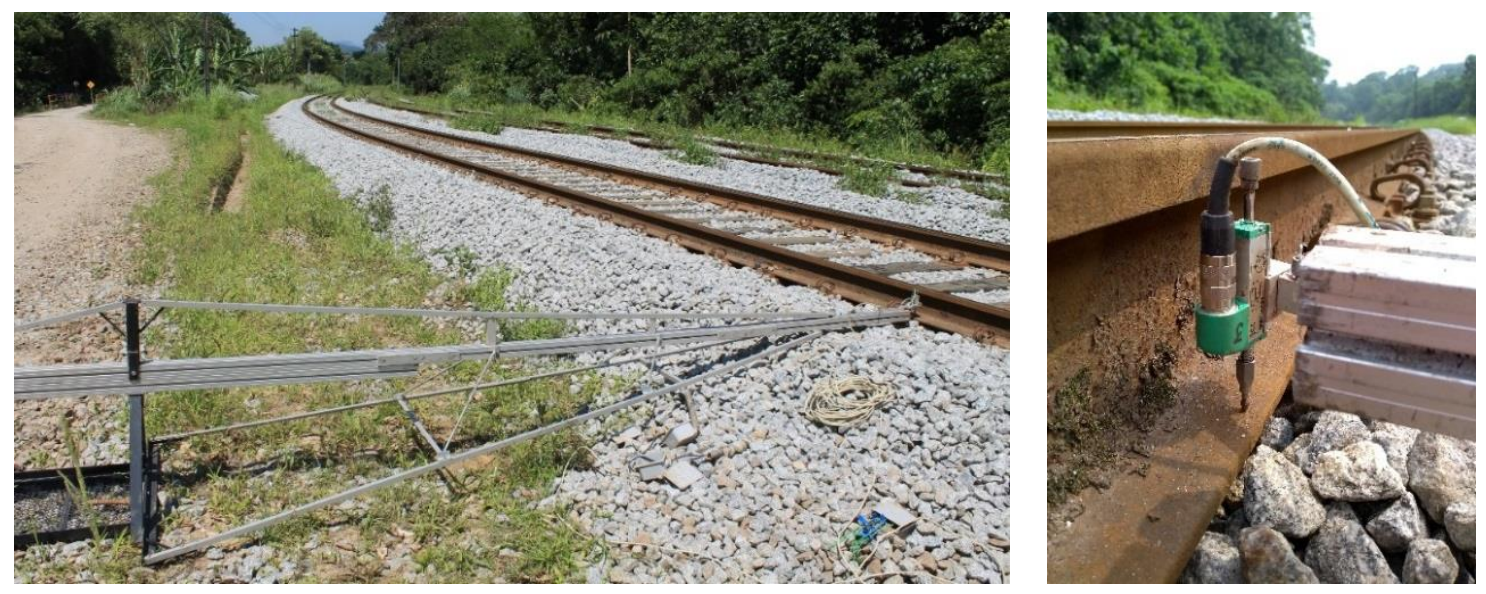

O comprimento das hastes do equipamento é tal que assegura a leitura dos deslocamentos fora da área de atuação dos efeitos dinâmicos oriundos da passagem do material rodante na via permanente (Figura 39). Os sensores do tipo LVDTs são capazes de captar deslocamentos verticais e longitudinais com precisão da ordem de 0,1 mm, a depender da maneira como estão dispostos (COSTA, 2016). 
As medidas são feitas sem que seja necessária a interrupção do tráfego. De posse de valores de deslocamento (deflexões) e de informações referentes ao material rodante, fornecidos pela MRS, tornou-se possível o cálculo de Módulo de Via (u), importante parâmetro para avaliar a resposta elástica e a rigidez do pavimento ferroviário.

Figura 39. Detalhes em planta e perfil do Dispositivo para Medição de Deslocamentos

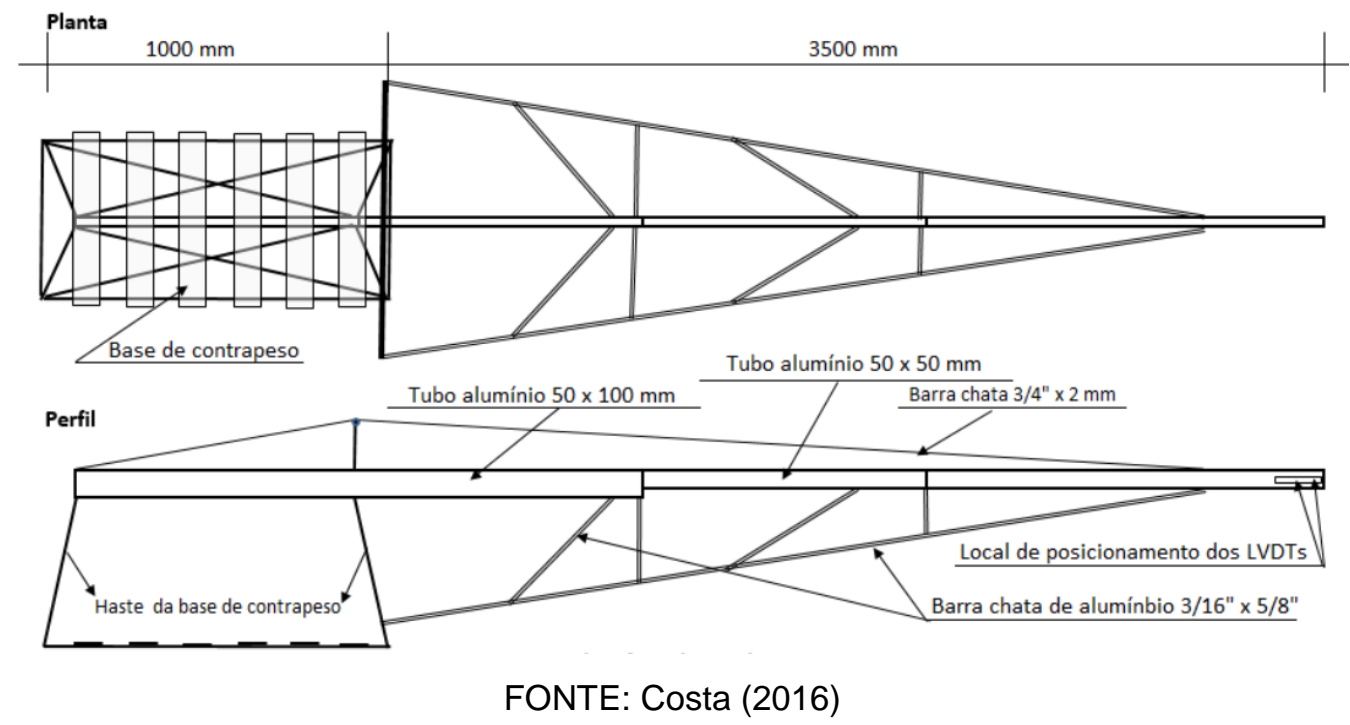

Digital Track Geometry Trolley

O carro eletrônico de medição de parâmetros geométricos é um aparelho compacto, empurrado a mão, capaz de medir em contínuo a bitola, a inclinação e o empeno de vias permanentes, relativamente a duas bases de referência (Figura 40). O equipamento usado é denominado Trolley AMBER, de fabricação da Geismar. 
Figura 40. Trolley AMBER em operação na via e gravador manual de geometria
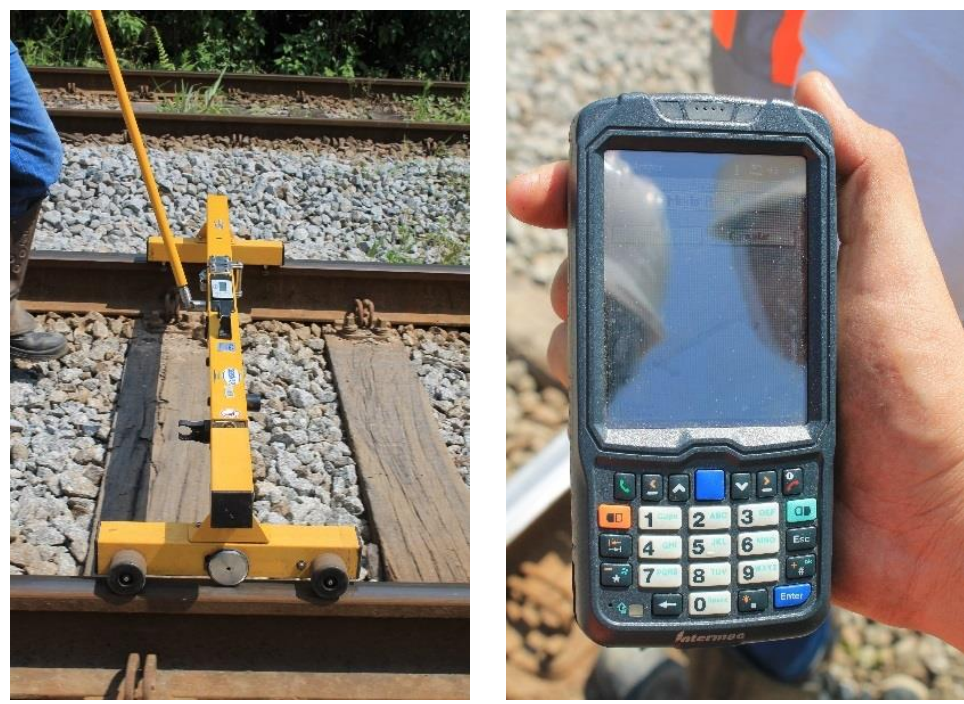

As leituras de acompanhamento com o Trolley Amber foram feitas trimestralmente (junho, setembro e dezembro de 2017), por meio da varredura contínua nas seções com sublastro betuminoso, sublastro granular e sem intervenção. Os pontos foram registrados a intervalos fixos de $500 \mathrm{~mm}$ e gravados de maneira vinculada às coordenadas geográficas obtidas por GPS (Sistema de Posicionamento Global).

\subsection{Caracterização física e mecânica dos materiais}

Amostras de todos os materiais que compunham a subestrutura da via permanente estudada foram coletadas e encaminhadas ao LTP-EPUSP para realização de ensaios de caracterização física e mecânica. Todos os procedimentos executados pautaram-se em recomendações propostas pela Associação Brasileira de Normas Técnicas (ABNT), American Railway Engineering and Maintenance-of-Way Association (AREMA), American Society for Testing and Materials (ASTM), Departamento Nacional de Estradas de Rodagem (DNER) e Departamento Nacional de Infraestrutura de Transportes (DNIT). 


\subsubsection{Materiais granulares}

Solo do subleito

O comportamento mecânico de camadas geotécnicas é regido por uma série de características intrínsecas ao material granular que as compõe, combinadas às condições de umidade e configurações de tensões e deformações às quais se encontram. Uma análise adequada do comportamento do solo para fins de engenharia inicia-se com a classificação do mesmo, baseando-se em índices físicos tais como o tamanho dos grãos e a consistência do solo, na medida em que se varia seu teor de umidade (líquido, plástico, semissólido ou sólido).

Os procedimentos adotados para separação de amostras e classificação do solo do subleito do trecho estudado seguiram as normas: ABNT NBR 6457:2016, ABNT NBR 7181:2016, ABNT NBR 6459:2016 e ABNT NBR 7180:2016.

Considerando-se as peculiaridades mecânicas e hidráulicas inerentes aos solos tropicais típicos no Brasil, procedeu-se à classificação do solo do subleito também pela metodologia MCT (Miniatura, Compactado, Tropical) proposta por Nogami e Villibor (1994). Esta, realizada por meio de ensaios em corpos de prova de tamanho reduzido, permite hierarquizarem-se os solos inicialmente em duas grandes classes: os de comportamento laterítico e os de comportamento não laterítico.

O ensaio de Mini-MCV fornece uma família de curvas de compactação similares às de Proctor. Cada curva é obtida para um determinado teor de umidade com sequência de golpes crescente, ou seja, com variações na energia de compactação empregada. A correlação entre o número de golpes com o valor de afundamento de cada corpo de prova gera as chamadas curvas de deformabilidade, de onde se obtém o coeficiente c'. Das curvas de massa específica aparente seca versus umidade de compactação obtém-se o coeficiente d'. Posteriormente, cada corpo de prova é submetido ao ensaio de Perda de Massa por Imersão, através do qual é mensurada a massa desprendida do corpo de prova quando submergido e o seu consequente fator de redução. A curva 
que correlaciona os valores de perda de massa com os de Mini-MCV fornece o parâmetro $\mathrm{Pi}_{\mathrm{i}}$.

O índice e', por sua vez, é calculado fazendo-se uso dos já obtidos coeficiente d' e Pi, e constitui-se como indicador do comportamento laterítico ou saprolítico do solo. Juntamente com o coeficiente c', que indica a tendência mais argilosa ou arenosa do material (referente à granulometria), efetua-se a classificação do solo utilizando-se o Gráfico Classificatório apresentado na Figura 41.

Figura 41. Gráfico para classificação de solos tropicais

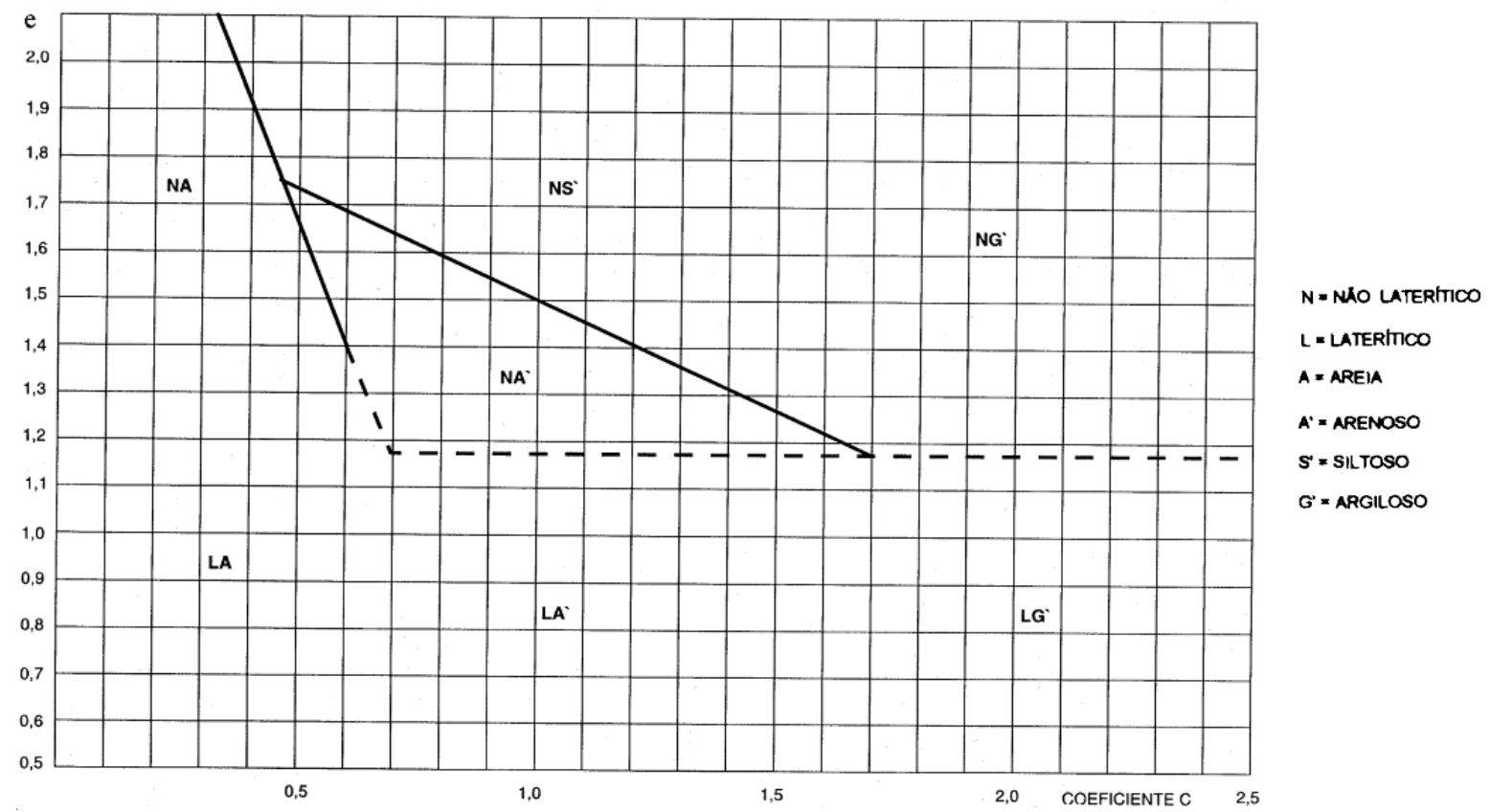

FONTE: adaptado DNER-CLA 259:96.

Os procedimentos adotados para todos os ensaios e cálculos referentes à metodologia MCT seguiram as recomendações das seguintes normas técnicas: DNER-ME 228/94, DNER-ME 256/94, DNER-ME 258/94, e DNER-CLA 259:96.

O Método das Pastilhas, ou Método de Identificação Expedita com a referida metodologia também foi empregado na presente pesquisa visando-se classificar o solo do subleito. O método tem por objetivo mensurar-se a contração diametral de amostras moldadas em anéis de inox, quando da perda de umidade; e verificar-se o aparecimento de trincas, expansão e resistência à penetração com uso de um 
penetrômetro padrão, quando as mesmas amostras são umedecidas (embebição por meio de uma placa porosa saturada). As amostras de solo utilizadas para tais procedimentos constituíram-se da fração de solo passante na peneira de abertura $0,42 \mathrm{~mm}$, que passaram por um processo de espatulação, anteriormente à moldagem, conforme requer este teste.

Uma vez obtidos valores de contração e expansão, e realizadas as devidas observações complementares, efetua-se a classificação do solo mediante análise da Carta de Classificação apresentada na Figura 42.

Figura 42. Carta de Classificação do Método das Pastilhas

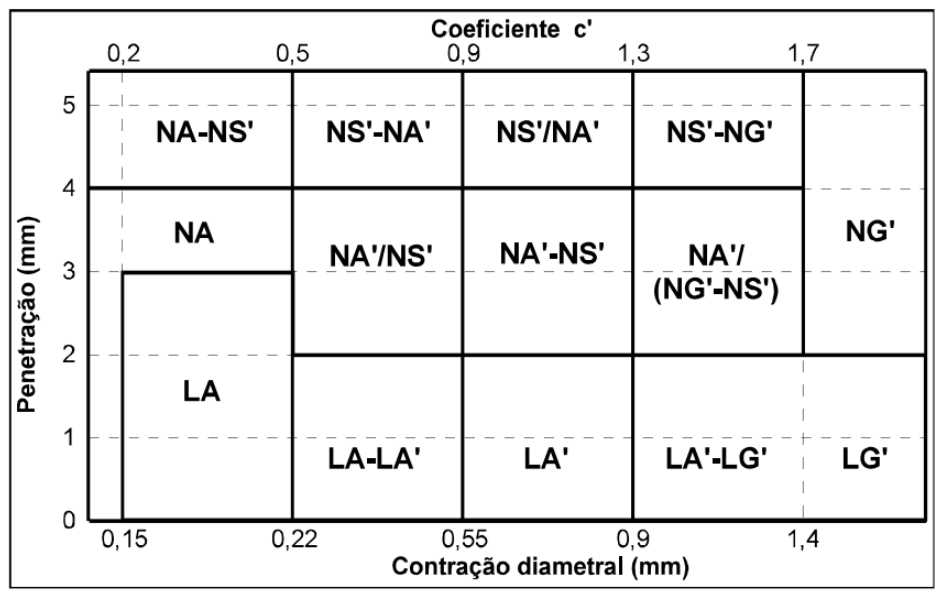

FONTE: Fortes, Merighi e Zuppolini Neto (2002)

Foram determinados o teor de umidade ótimo e a massa específica aparente seca máxima do solo através da curva de compactação, obtida à energia normal e com reuso de material, de acordo com a norma ABNT NBR 7182:2016. De forma semelhante, realizou-se o Ensaio de Compactação em Equipamento Miniatura (DNER-ME 228/94), também com o emprego da energia normal, sem reuso de material e utilizando-se somente a fração passante na peneira de 2,00 mm de abertura para compor os cinco corpos de prova deste teste, cada um com 50 mm de diâmetro.

Com o intuito de se determinar o módulo de resiliência do solo, executou-se o ensaio triaxial dinâmico em um corpo de prova cilíndrico (100 X 200 mm) compactado à energia normal, seguindo-se a norma DNIT 134/2010 - ME. Este ensaio consiste em se aplicar uma sequência de 18 pares de tensões a um corpo de prova e se 
registrarem as deformações específicas correspondentes após determinadas repetições de carga, por intermédio de dois transdutores do tipo LVDT acoplados em posições diametralmente opostas do corpo de prova. O cálculo do módulo é dado pela relação entre a tensão desvio aplicada, ou tensão de confinamento, e a deformação específica recuperável medida.

A curva característica do solo foi obtida por meio de três métodos de ensaio distintos: placa de sucção, translação de eixos (placa de pressão) e papel filtro. Três corpos de prova (CPs) miniatura foram moldados à energia normal e com teores de umidade variados: CP 1 - teor de umidade ótimo, obtido no ensaio de compactação (ABNT NBR 7182:2016); CP 2 - teor de umidade ótimo + 2\%; e CP 3 - teor de umidade ótimo - 2\%. O procedimento empregado para a obtenção da curva de retenção partiu da condição saturada das amostras, ou seja, foram obtidas pelo processo de secagem.

De maneira simplificada, o ensaio da placa de sucção consiste em impor um determinado valor de sucção (0 a $30 \mathrm{kPa}$ ) aos corpos de prova situados sobre uma pedra porosa de alta entrada de ar (100 kPa). Esta, previamente saturada, é inserida em uma base de latão que se conecta pela base por um tubo plástico preenchido com água, ligado a um reservatório de água na sua outra extremidade (OLIVEIRA, 2004). A sucção aplicada pela pedra porosa está relacionada à diferença da sua altura em relação ao recipiente de água, e seu esquema pode ser visualizado na Figura 43. Um desnível de $1 \mathrm{~m}$ corresponde a uma sucção de $10 \mathrm{kPa}$.

Figura 43. Esquema do aparato utilizado no ensaio da placa de sucção (fora de escala)

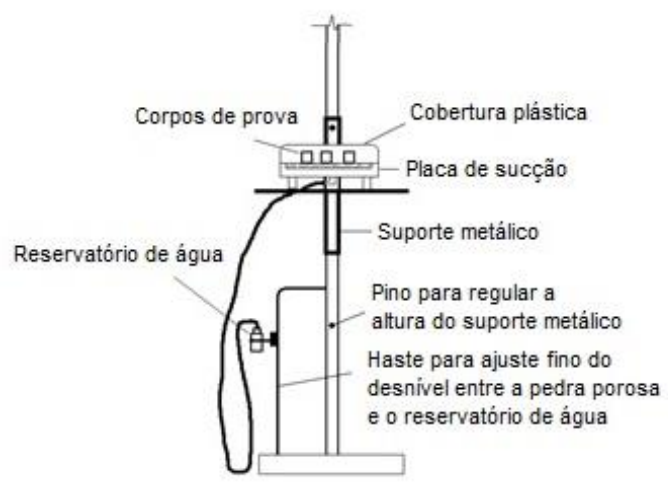

FONTE: Oliveira (2004) 
A técnica de translação de eixos é similar ao ensaio de placa de sucção, distinguindose pela possibilidade de controle adicional da pressão de ar do sistema. Para tanto, utiliza-se uma câmara conhecida como placa de pressão, vedada por seis parafusos que conectam sua base a uma tampa, proporcionando um ambiente capaz de suportar elevadas pressões de ar (Figura 44). Para cada estágio de sucção desejado (até 1.500 kPa), impõe-se uma pressão de ar equivalente dentro da câmara e é medido o volume de água expulso em uma bureta graduada acoplada ao sistema (BONDER, 2008).

Figura 44. Placa de pressão

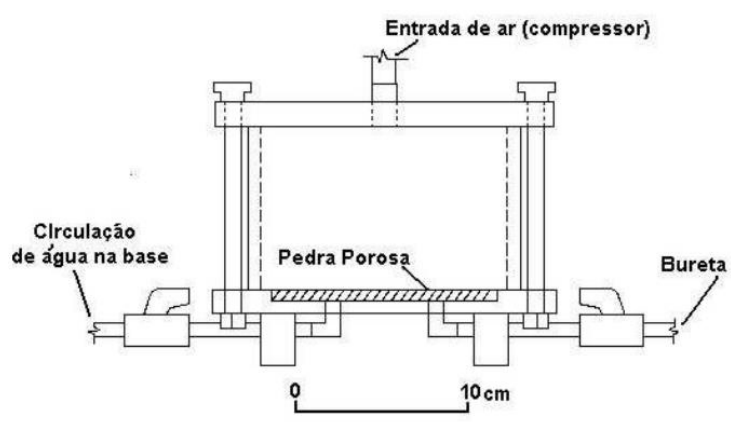

FONTE: Oliveira (2004)

O método do papel filtro, por sua vez, não requer aparatos específicos tal como os métodos anteriormente citados. Consiste, basicamente, em se colocar um material poroso (papel filtro), de características de retenção conhecidas, em contato com o solo num ambiente hermeticamente fechado até que se atinja um estado de equilíbrio e as sucções se igualem. Atingido este equilíbrio, mede-se o teor de umidade do papel filtro, que corresponde a um valor de sucção baseado na sua curva de calibração (OLIVEIRA FILHO, 2004). Apesar do seu baixo custo e amplo intervalo de abrangência de sucções medidas (0 a $29.000 \mathrm{kPa}$ ), constitui-se como um ensaio delicado, uma vez que a pesagem do papel filtro deve ser feita em balança de quatro casas decimais e em não mais que 30 s, a fim de evitar que este ganhe ou perca umidade para a atmosfera.

As medidas de sucção matricial foram tomadas por meio da utilização de papel filtro do tipo Whatman $n^{\circ} 42$, em contato direto com o solo. A sucção obtida é resultado da média de três valores para cada corpo de prova: dois oriundos de papéis filtros dispostos em suas laterais e um no seu topo. O tempo de equilíbrio foi de sete dias, 
como recomendado na norma ASTM D 5298-03. Para cada ponto foram tomados os pesos dos CPs, três medidas de diâmetro e três medidas de altura com paquímetro.

Maiores detalhes quanto aos procedimentos empregados para obtenção da curva característica de retenção de água podem ser encontrados em MARINHO (1997), SOTO (2004), OLIVEIRA (2004), OLIVEIRA FILHO (2004) e BONDER (2008).

De forma geral, a granulometria e a composição mineralógica do solo são determinantes na posição relativa, forma e inclinação da curva de retenção de água (SOTO, 2004). Dessa maneira, ensaios para identificação da estrutura mineralógica do solo do subleito (difração de raios $X$ ) foram realizados em duas amostras distintas: uma composta por uma fração de solo passante na peneira de abertura 2,00 mm e outra composta por uma fração de solo passante na peneira de abertura 0,074 mm. Os ensaios de difração de raios $X$ foram executados pelo Laboratório de Caracterização Tecnológica da Universidade de São Paulo. Este estudo foi efetuado através do método do pó, mediante o emprego de difratômetro de raios $\mathrm{X}$ com detector sensível à posição. Em teoria, um feixe é difratado pelos cristalinos distribuídos aleatoriamente na amostra e estes, por sua vez, difratam o feixe incidente de forma que sejam coletados pelo detector (BONDER, 2008). O registro das identidades difratadas representa uma "impressão digital" da amostra e, neste estudo, foi obtido por comparação com os bancos de dados PDF2 do ICDD (International Centre for Diffraction Data) e do ICSD (Inorganic Crystal Structure Database).

Adicionalmente, amostras de solo retiradas durante a execução dos trechos experimentais foram utilizadas para determinação do teor de umidade de campo.

\section{Sublastro granular}

A caracterização do material que compõe o sublastro granular do trecho tido como referência iniciou-se pela análise granulométrica da amostra coletada em campo e da determinação do teor de umidade. Realizou-se, posteriormente, o ensaio de compactação, sem reuso de material, para obtenção do teor de umidade ótimo e da massa específica aparente seca máxima. Apesar de se recomendar para este material 
o emprego da energia modificada para moldagem dos corpos de prova, optou-se por utilizar a energia normal, uma vez que se buscava analisar a condição do material tal qual aquela encontrada em campo. Devido a adversidades construtivas, a camada de sublastro granular não passou por um processo de compactação controlado na renovação da via e, portanto, determinou-se como alternativa mais fiel adotar-se uma energia de compactação reduzida também em laboratório. Assim, o ensaio triaxial dinâmico para determinação do módulo de resiliência foi realizado em corpo de prova cilíndrico (100 X 200 mm) compactado à energia normal e com teor de umidade ótimo obtido através do ensaio de compactação.

Os procedimentos anteriormente citados seguiram as normas: ABNT NBR NM 248:2003, ABNT NBR 7182:2016 e DNIT 134/2010.

Lastro

A caracterização física dos agregados que compõem a camada de lastro foi realizada através da medição de propriedades de tamanho, forma e resistência à abrasão de amostra retirada da via permanente estudada, seguindo-se as normas: ABNT NBR 27:2001, ABNT NBR NM 248:2003, ASTM D4791 e ASTM C535.

\subsubsection{Mistura asfáltica}

Os ensaios realizados para caracterização física e mecânica do CBUQ empregado como sublastro da via permanente em estudo seguiram metodologias normatizadas e rotineiramente adotadas na pavimentação rodoviária. Buscou-se, no entanto, fazer-se uma avaliação do comportamento do material asfáltico à luz das condições as quais este se encontra em campo, sempre que possível. Dessa maneira, procedeu-se à extração de amostras indeformadas em janelas de inspeção localizadas na região da saia da subestrutura ferroviária, e, com estas, determinou-se o volume de vazios de campo de acordo com a norma ASTM D1188.

A determinação do teor de ligante asfáltico foi realizada pelo Método da Combustão, utilizando-se forno do tipo mufla, seguido da análise granulométrica dos agregados tal 
como preconizado na norma DNER-ME 083/98. A densidade máxima teórica (DMT) foi determinada através da aplicação de vácuo, procedimento denominado de Rice, e seguiu as diretrizes da ABNT NBR 15619.

O comportamento mecânico da mistura asfáltica foi avaliado por meio do ensaio de módulo de resiliência (DNIT 135/2010 - ME), a $25^{\circ} \mathrm{C}$. Os corpos de prova foram moldados seguindo-se os procedimentos da metodologia Marshall (ABNT NBR 15785/2010), porém com número de golpes modificado, a fim de que os corpos de prova apresentassem volume de vazios igual ao obtido nas amostras de campo previamente ensaiadas.

Adicionalmente, avaliou-se a sensibilidade do material betuminoso à ação deletéria da água. O procedimento adotado baseou-se na avaliação da resistência à tração por compressão diametral em dois grupos de corpos de prova distintos, moldados com volume de vazios de $7 \pm 1 \%$ : um grupo de controle e um grupo condicionado. $O$ grupo denominado condicionado foi induzido ao dano acelerado por umidade seguindo-se a norma ASTM D4867/D4867M - 09, enquanto o grupo de controle permaneceu com condições iniciais de moldagem. O critério para aceitação de uma mistura asfáltica para pavimentos rodoviários (camada de rolamento ou de ligação) é dado em porcentagem de propriedade mecânica retida, que no Brasil é de $70 \%$, como sugerido pela ASTM. 


\section{RESULTADOS E DISCUSSÕES}

\subsection{Ensaios preliminares "in situ"}

O resultado do ensaio DCP realizado na linha 2 PG-RS, iniciado a uma profundidade de $350 \mathrm{~mm}$ abaixo da base do dormente, pode ser observado na Figura 45. O ensaio foi realizado no início do mês de fevereiro de 2017, período com altos índices pluviométricos na região. Percebe-se, pelo gráfico, que os valores de CBR aumentam com a profundidade, em uma tendência linear, além de indicarem boa capacidade de suporte do subleito.

Figura 45. Representação gráfica dos valores obtidos pelo ensaio de DCP

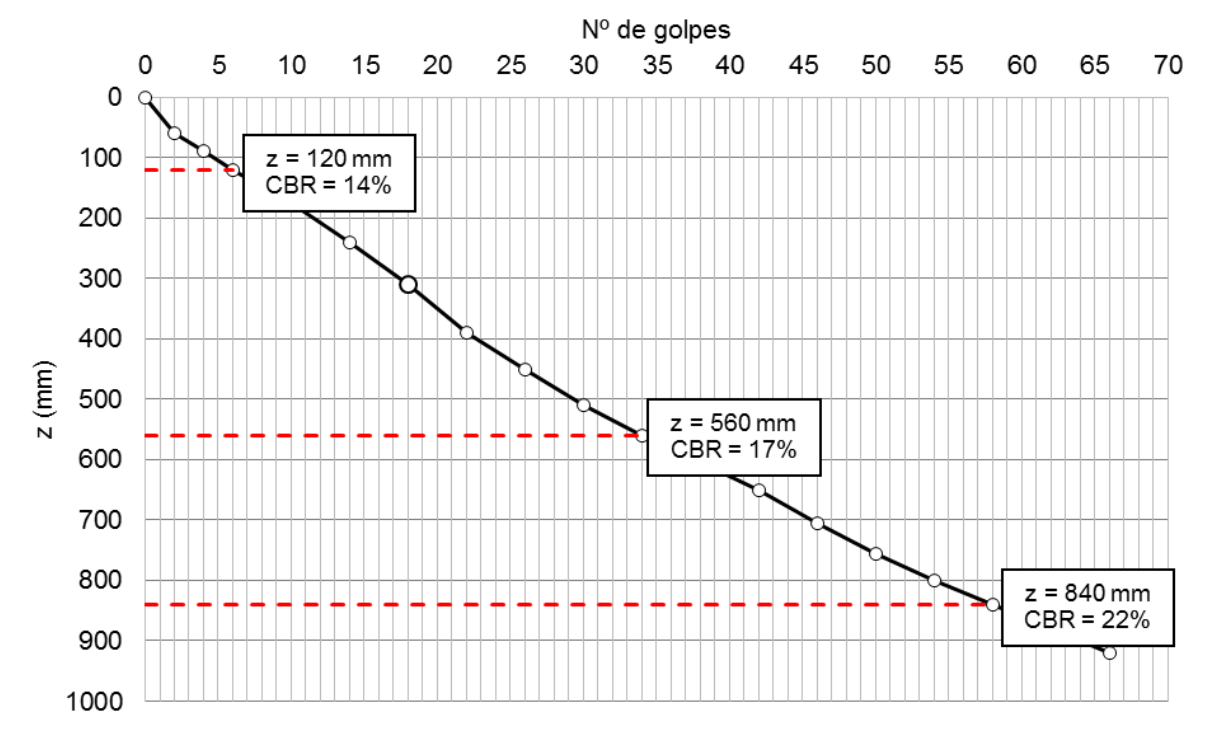

A capacidade de suporte obtida a $120 \mathrm{~mm}$, profundidade para qual se dimensionou, aproximadamente, o assentamento da camada de sublastro (profundidade efetiva de $470 \mathrm{~mm}$ a medir da base do dormente), atende satisfatoriamente o valor recomendado pela Instrução de Serviço Ferroviário do DNIT (ISF - 207: Estudos Geotécnicos), que determina CBR mínimo de $10 \%$ para camada subjacente ao sublastro. Frente a este resultado, a execução dos trechos experimentais foi feita contemplando a etapa de "agulhamento" de camada monogranular de lastro apenas visando a circulação mais segura de equipamentos durante o processo construtivo, não havendo necessidade de execução de reforço ou tratamento da camada de subleito em ambos os casos. 
O ensaio LWD apresentou valor médio de módulo de resiliência para o ponto analisado de $19 \mathrm{MPa}$. A princípio, analisando-se singularmente o valor obtido, constata-se que este está aquém do mínimo recomendado para camada de subleito de via permanente ferroviária em países como Itália e Estados Unidos da América (80 $\mathrm{MPa}$ ), e classificaria a plataforma estudada como camada de baixa capacidade de suporte. Entretanto, a aferição da capacidade de carga da camada para meios de aceitação ou não em padrões estruturais pode ser realizada por diferentes métodos. Deve-se considerar, inclusive, que os valores de módulo de resiliência obtidos por retroanálise de medidas de deflexão em ensaios dinâmicos "in situ" podem possuir ou não correlação com valores de módulo de resiliência obtidos em laboratório, por exemplo. Este último chegando a atingir magnitudes até quatro vezes superiores aos valores obtidos em ensaios de campo (RAHIM e GEORGE, 2003) e sendo aqueles adotados, mais comumente, como dados de entrada em simulações numéricas visando avaliação estrutural de pavimentos. Assim, frente à limitação de informações quanto a metodologia pela qual se procede a determinação do módulo da camada de subleito em outras localidades, preferiu-se considerar a condição "in situ" da plataforma pelo resultado oriundo do ensaio de DCP no que tange às atividades construtivas de renovação da via.

\subsection{Espessuras efetivas das camadas}

Posteriormente à execução dos dois trechos experimentais, com a via já em operação normalizada, realizaram-se inspeções para verificação da integridade dos materiais e das reais espessuras das camadas construídas, através da abertura de janelas de inspeção (Figura 46). As mesmas foram executadas na região do ombro referente ao trilho externo da linha 2 PG-RS, a fim de evitarem-se maiores danos à subestrutura por desestabilização das camadas. 
Figura 46. Verificação de espessura de lastro no trecho com sublastro granular

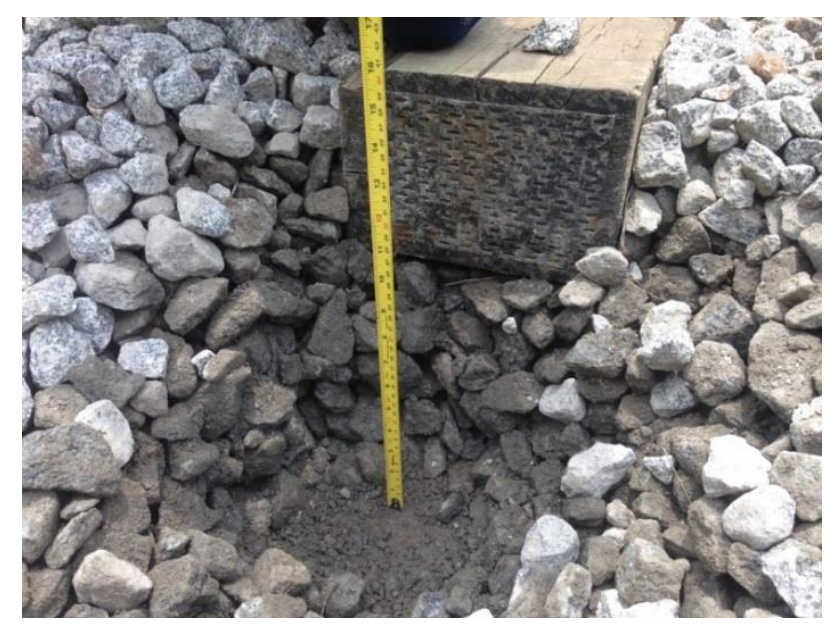

Observou-se, por intermédio destas verificações, que as espessuras das camadas da subestrutura da via eram inferiores àquelas projetadas. A camada de sublastro betuminoso possuía espessura efetiva de $100 \mathrm{~mm}$, isto é, $25 \mathrm{~mm}$ a menos do que a determinada em projeto, enquanto a camada de sublastro granular encontrava-se com somente $80 \mathrm{~mm}$ de espessura, ou seja, era $20 \%$ menor em relação à dimensionada para a seção. As dificuldades atreladas ao reduzido período de execução dos trechos experimentais desencadearam atrasos, reajustes inesperados e controle insuficiente da espessura das camadas à medida que estas eram compactadas. Por este motivo, para as análises deste estudo, decidiu-se por fazê-las sempre em função das espessuras encontradas com a abertura de janelas de inspeção.

Apesar de estarem em discordância com o dimensionado, a camada betuminosa encontra-se dentro da faixa encontrada por Rangel et al. (2015) para que ocorra efetivamente a redução das tensões que atingem 0 topo do subleito, comparativamente a uma estrutura contendo sublastro granular de $200 \mathrm{~mm}$ de espessura (item 2.2.2). Diferencialmente, a camada de sublastro do trecho tido como referência encontra-se abaixo do limite recomendado por manuais ferroviários americanos para sublastro granular, que é de 150 mm (SELIG e WATERS, 1994).

A camada de lastro também merece destacada atenção dentre as constatações tiradas do campo, pois desempenha um importante papel no comportamento mecânico em termos de rigidez e resiliência da via, atenuando vibrações e distribuindo as tensões de forma minimizada para as camadas subjacentes, dentre outras funções. 
Esta se encontra cerca de $40 \%$ mais delgada no trecho contendo sublastro granular e fora da faixa de espessura comumente adotada em vias permanentes brasileiras (200 $\mathrm{mm}$ a $300 \mathrm{~mm}$ ). Dessa maneira, as análises da resposta mecânica da via permanente tratadas mais à frente neste estudo devem ser recebidas com a ciência de que, apesar de possuírem o mesmo regime de tráfego, os trechos monitorados possuem diferentes espessuras de camada de lastro (trecho betuminoso com $300 \mathrm{~mm}$ e trecho granular com $180 \mathrm{~mm}$ ). Além disso, deve-se ter em mente que a referida discrepância pode influenciar significativamente nos resultados de deslocamentos medidos e, por conseguinte, no comportamento global da via.

\subsection{Dados oriundos da instrumentação}

Células de pressão total

Das quatro células inseridas nos trechos estudados, duas sofreram danos durante 0 período monitorado, impossibilitando análises quanto à distribuição de tensões ao longo das camadas constituintes do pavimento ferroviário. A célula inserida na interface sublastro/subleito do trecho contendo mistura asfáltica não registrou leitura em nenhuma das campanhas, possivelmente tendo sido avariada durante o processo executivo, uma vez que sua sensibilidade pode não ter sido capaz de suportar os esforços de compactação, apesar dos cuidados tomados durante a execução do trecho.

A célula inserida na interface dormente/lastro do trecho com sublastro betuminoso computou uma única leitura, em agosto de 2017, registrada na Figura 47. Tensões verticais de compressão consequentes da passagem de duas locomotivas com carga por eixo média de 31 toneladas tiveram picos de $93 \mathrm{kPa}$ (mínimo) e $143 \mathrm{kPa}$ (máximo). Já os vagões de tipos e carregamentos diferentes (carga por eixo média de 23 toneladas) geraram picos de tensão de compressão de 75 kPa (mínimo) e 123 kPa (máximo) no topo do lastro. 
Figura 47. Sinal registrado pela célula de pressão inserida na interface dormente / lastro do trecho com sublastro betuminoso

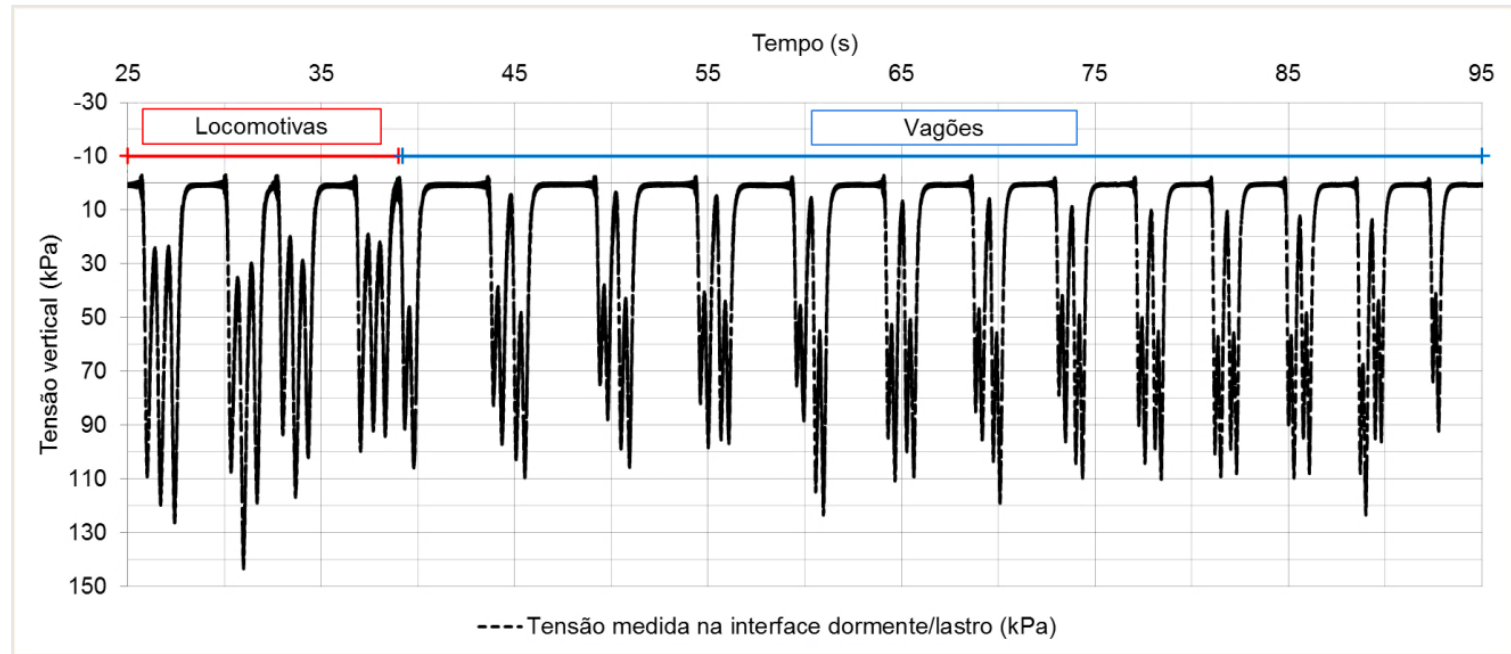

As magnitudes das tensões medidas no topo da camada de lastro estão em concordância com as obtidas em simulações numéricas realizadas por Rangel et al. (2015). Este, simulando uma carga de 32 ton/eixo em uma estrutura contendo camada de lastro de $300 \mathrm{~mm}$ (MR de $130 \mathrm{MPa}$ ) e de sublastro betuminoso de $100 \mathrm{~mm}$ de espessura, obteve tensões variando de 153 kPa a 157 kPa para módulos de resiliência da mistura asfáltica de $3.000 \mathrm{MPa}$ a $9.000 \mathrm{MPa}$, respectivamente, e mantendo o MR do subleito em $80 \mathrm{MPa}$. Ademais, deve-se atentar para o fato de que a via, até o momento analisado, havia acumulado 1 MTBT de tráfego, valor este dentro da faixa considerada de estabilização da camada de lastro, que vai de 0,5 a 2 MTBT, segundo Esveld (2001).

Na seção com sublastro granular, tida como referência, a célula de pressão inserida na interface dormente/lastro registrou satisfatoriamente tensões verticais em três campanhas e a célula localizada na interface sublastro/subleito registrou tensões em todas as campanhas. Informações quanto às magnitudes médias registradas e carga por eixo do material rodante podem ser obtidas na Tabela 3. A velocidade média de operação da via é de $20 \mathrm{~km} / \mathrm{h}$ e, entre as campanhas de novembro e dezembro, as seções estudadas passaram por atividade mecanizada de socaria, possivelmente sendo a causa, mas não somente, da redução das tensões medidas em ambas as interfaces para as duas leituras seguintes. 
Tabela 3. Valores de tensão de compressão medidas no trecho com sublastro granular

\begin{tabular}{|c|c|c|c|c|c|c|}
\hline \multirow[t]{2}{*}{ Data } & \multirow[t]{2}{*}{ Descrição } & \multicolumn{2}{|c|}{$\begin{array}{c}\text { Carga por eixo média } \\
\text { (ton) }\end{array}$} & \multirow{2}{*}{$\begin{array}{c}\text { MTBT } \\
\text { - acumulado }\end{array}$} & \multicolumn{2}{|c|}{ Tensão média medida (kPa) } \\
\hline & & Locomotivas & Vagões & & Dormente / Lastro & Topo do subleito \\
\hline Agosto/2017 & Composição carregada & 31 & 23 & 1,0 & $\mathrm{NC}$ & 5,97 \\
\hline Outubro/2017 & Composição carregada & 30 & 30 & 1,7 & $\mathrm{NC}$ & 10,93 \\
\hline Outubro/2017 & Composição vazia & 30 & 7 & 1,7 & $\mathrm{NC}$ & 7,81 \\
\hline Novembro/2017 & Composição carregada & 30 & 26 & 2,3 & 113,02 & 18,86 \\
\hline Dezembro/2017 & Composição carregada & 29 & 24 & 2,6 & 92,37 & 12,01 \\
\hline Dezembro/2017 & Locomotivas & 30 & - & 2,6 & 92,07 & 11,36 \\
\hline
\end{tabular}

Um dos objetivos deste estudo, o de verificar o ganho estrutural consequente do emprego de sublastro betuminoso, homogeneizando e reduzindo as tensões de compressão que atingem o topo do subleito, de forma comparativa a uma camada de sublastro granular, não pôde ser atingido devido às adversidades comumente encontradas em muitos trabalhos desenvolvidos em campo. No entanto, esforços são feitos para que as informações obtidas sirvam de referência para estudos futuros que levem em consideração as condições às quais vias permanentes de carga brasileiras estão sujeitas, e como aprendizado para as próximas experiências no que tange à instrumentação de trechos experimentais e o risco de perda de sensores.

\section{Sensores de temperatura}

As medidas de temperatura tomadas nos trechos estudados mostraram que existem reduzidas variações térmicas nas camadas de sublastro betuminoso e granular, nas direções vertical e transversal, à medida que as condições climáticas se alteram. Pode-se observar pela Figura 48 que, apesar da posição dos sensores diferirem, o gradiente térmico atuante na camada de mistura asfáltica permanece abaixo de $1^{\circ} \mathrm{C}$ quando comparados, mês a mês: valor de gradiente térmico médio na direção vertical de $0,4^{\circ} \mathrm{C}$ e na direção transversal de $0,5^{\circ} \mathrm{C}$ da camada betuminosa. Para a estrutura contendo sublastro granular (Figura 49), o gradiente térmico na direção transversal, analisado mensalmente, também permanece significativamente baixo, com valor médio de $0,4^{\circ} \mathrm{C}$. 
Figura 48. Temperaturas medidas na camada de sublastro betuminoso
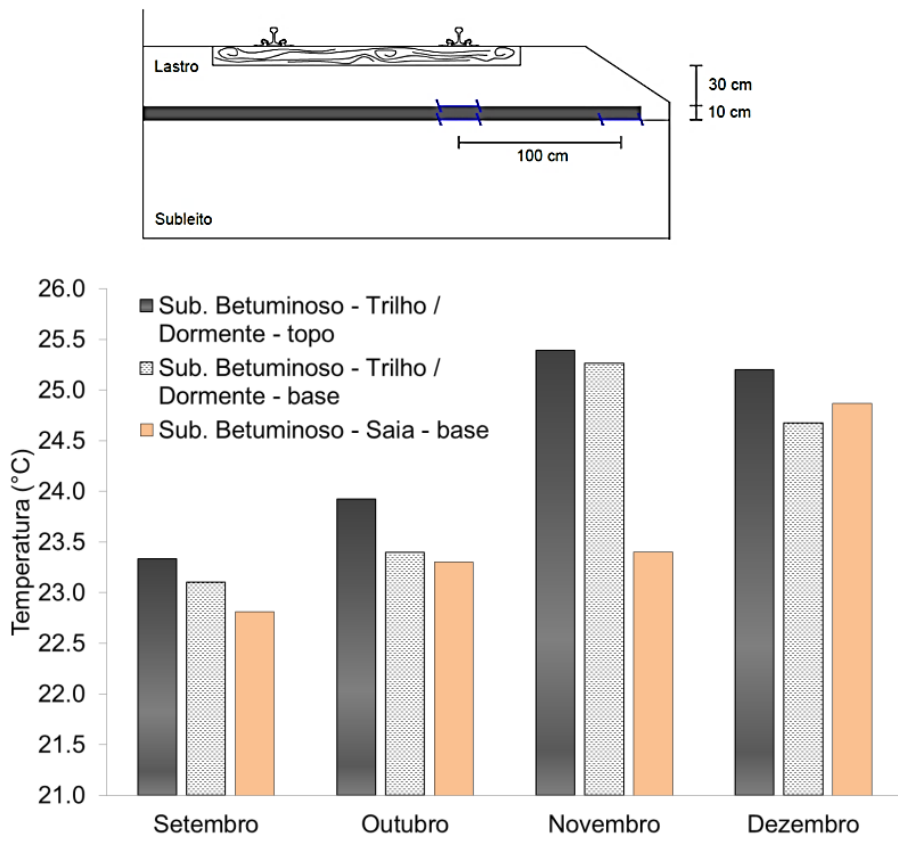

Figura 49. Temperaturas medidas na camada de sublastro granular
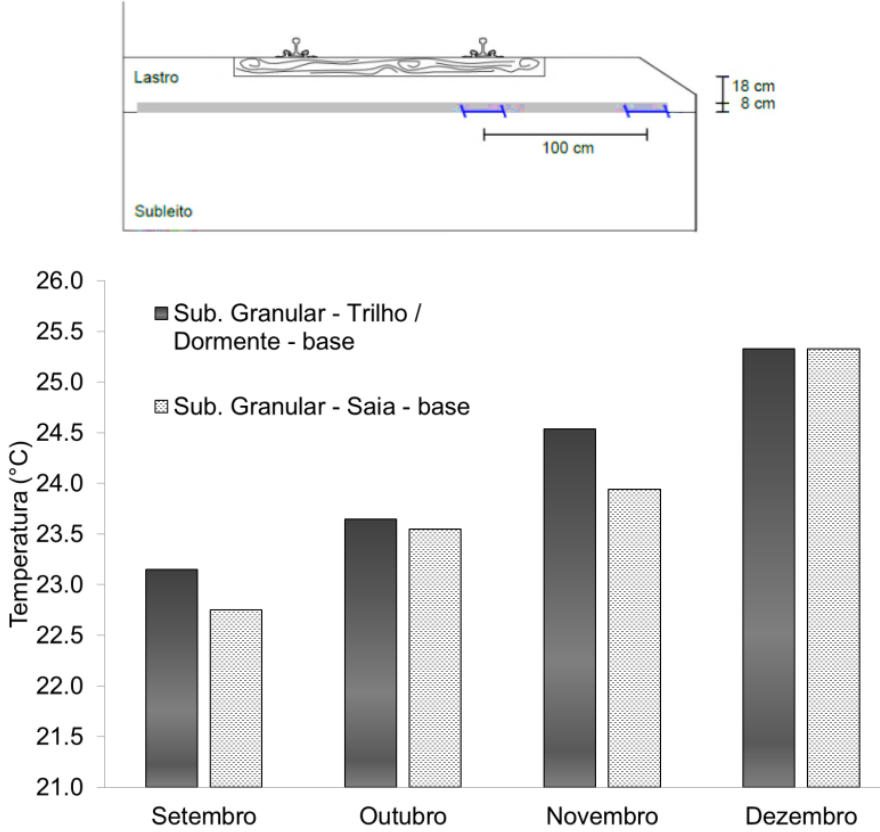

As medidas realizadas nas seções experimentais de sublastro betuminoso não contemplaram a gama de variáveis necessárias para uma análise detalhada da variação térmica na camada, porém indicam uma tendência de variação bastante reduzida quando comparadas àquelas medidas em revestimentos asfálticos expostos diretamente a mudanças rápidas de temperatura do ar e de insolação, principal causa de fluxo de calor através ou para o pavimento (MOTTA, 1991). Os gradientes térmicos 
mais significativos manifestaram-se com o passar dos meses, com variações da ordem de $2^{\circ} \mathrm{C}$ para temperaturas medidas logo abaixo do eixo de encontro do trilho com o dormente e para as temperaturas medidas na região da saia do pavimento ferroviário, ambos na base das camadas de sublastro (Figura 50). Tal fenômeno devese particularmente ao fato de que os meses nos quais tais medidas foram registradas são caracterizados por um crescente aumento de temperatura média na região, conforme se aproxima o verão.

Figura 50. Temperaturas medidas em sensores de mesma posição em ambas configurações de sublastro
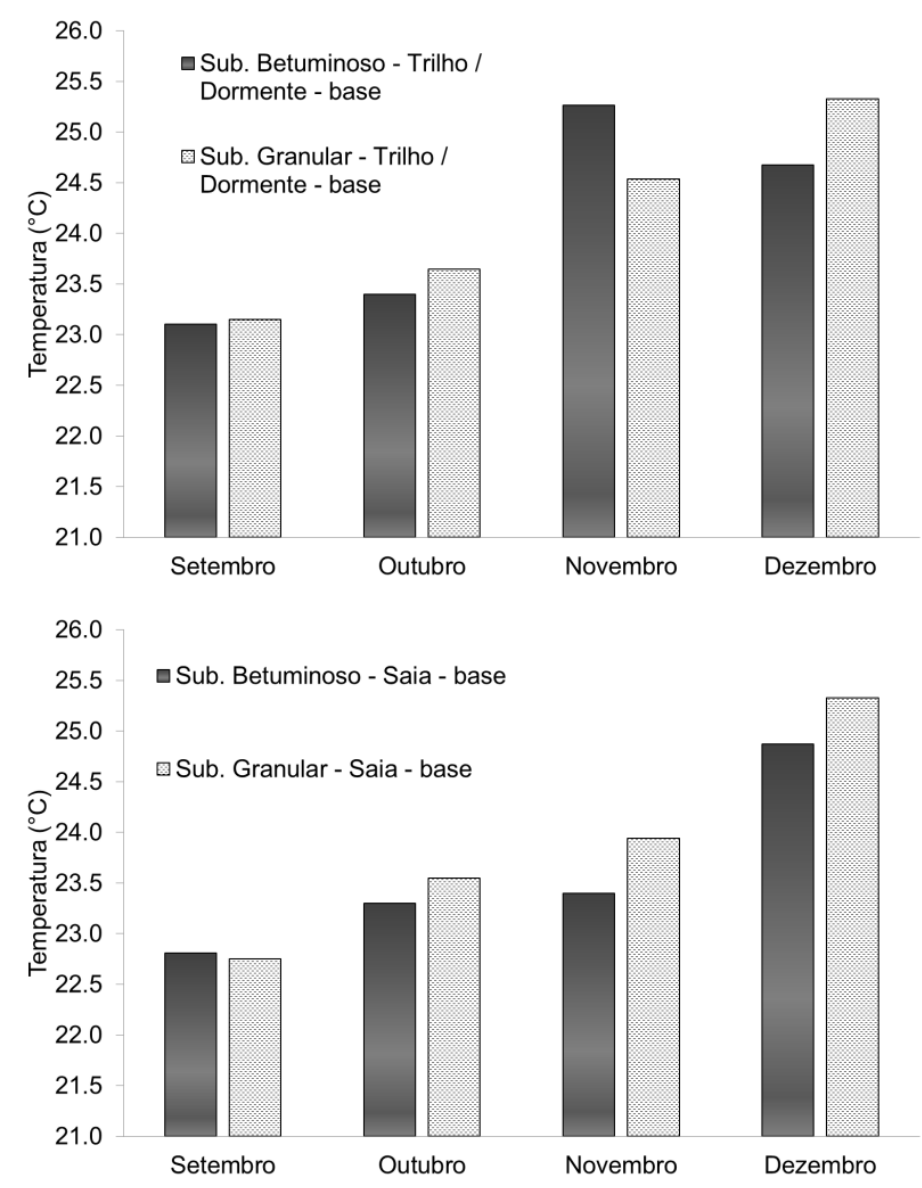

É sabido que o desempenho de camadas betuminosas é regido, em parte, pela variação de temperatura a qual a mesma é exposta durante sua vida útil. De maneira simplificada, misturas asfálticas tendem a ter um comportamento mais rígido em temperaturas mais baixas e, a temperaturas mais altas, comportam-se de forma mais flexível, induzindo a um amolecimento diferencial ao longo da camada betuminosa (MOTTA, 1991). Ratificando o que Rose e Bryson (2009) haviam afirmado, e 
baseando-se nas medidas de campo realizadas, pode-se descartar o aparecimento de defeitos oriundos de variações de temperatura na camada de sublastro betuminoso, pois os gradientes térmicos atuantes não atingem magnitudes capazes de provocar afundamento plástico (altas temperaturas) ou trincamento térmico (baixas temperaturas) para as condições climáticas analisadas.

Observando-se a Figura 50, percebe-se também que na base da camada betuminosa as magnitudes de temperatura medidas diferem minimamente daquelas registradas na base da camada granular. Tal indicação sinaliza que, apesar de reter calor devido à sua baixa condutividade térmica, a camada de sublastro betuminoso não aquece as camadas subjacentes em maior escala que camadas granulares e, por conseguinte, não pode ser considerada como destacada causa para geração de fluxos de água na camada de subleito por diferença de temperatura. Recomenda-se, no entanto, que avaliações mais aprofundadas do tema sejam realizadas, uma vez que o acompanhamento das seções não contemplou o período mínimo de um ano. Ademais, tratou de forma simplificada fatores tais como a variação de leituras: a depender da hora do dia, da profundidade de cada camada, das características da mistura, tais como classificação e teor de ligante, das condições atmosféricas, da localização geográfica do pavimento e das características termomecânicas do material de solo do subleito na geração de tensões térmicas atuantes na subestrutura da via.

\section{Sensores de sucção}

As tensões de sucção medidas entre os meses de julho e dezembro de 2017 podem ser observadas nas Figura 52 e Figura 53. Os sensores posicionados a $100 \mathrm{~mm}$ abaixo da interface sublastro/subleito serão considerados sensores de superfície, já os posicionados a um total de $300 \mathrm{~mm}$ abaixo desta interface serão considerados de profundidade, como visto na Figura 51. 
Figura 51. Posicionamento dos sensores nos trechos com sublastro (a) betuminoso e (b) granular

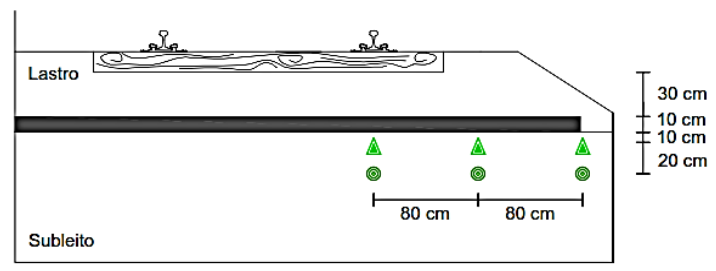

(a)

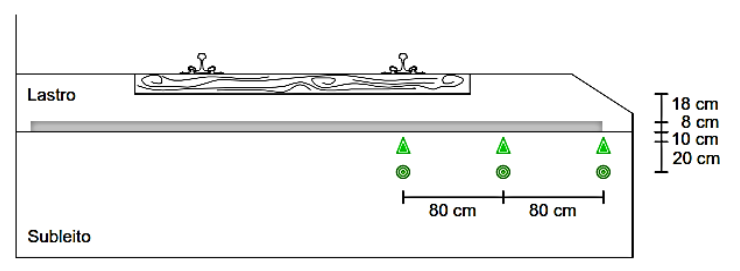

(b)

Figura 52. Tensões de sucção de superfície nos trechos com sublastro (a) betuminoso e (b) granular

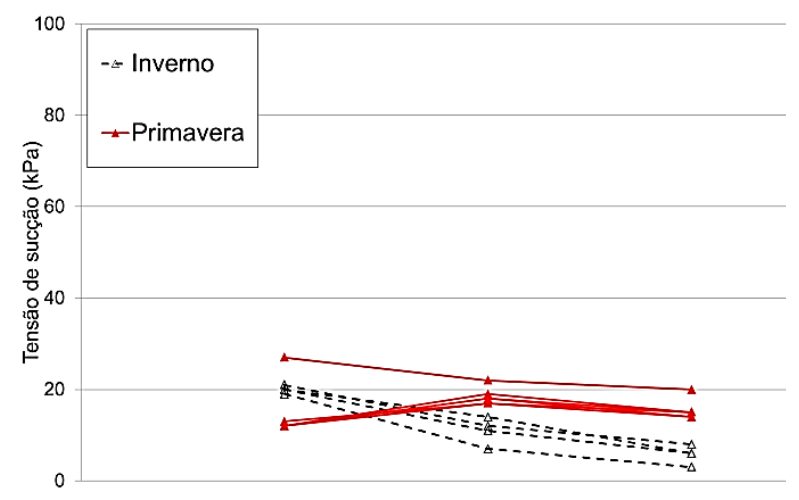

(a)

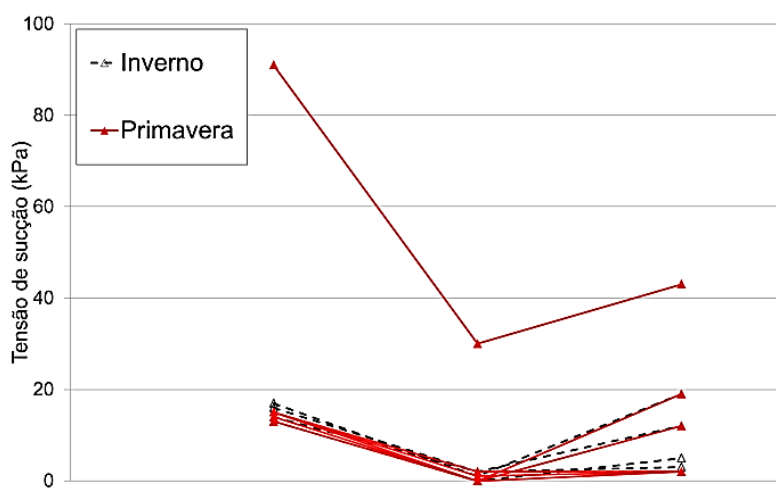

(b)

Figura 53. Tensões de sucção de profundidade nos trechos com sublastro (a) betuminoso e (b) granular

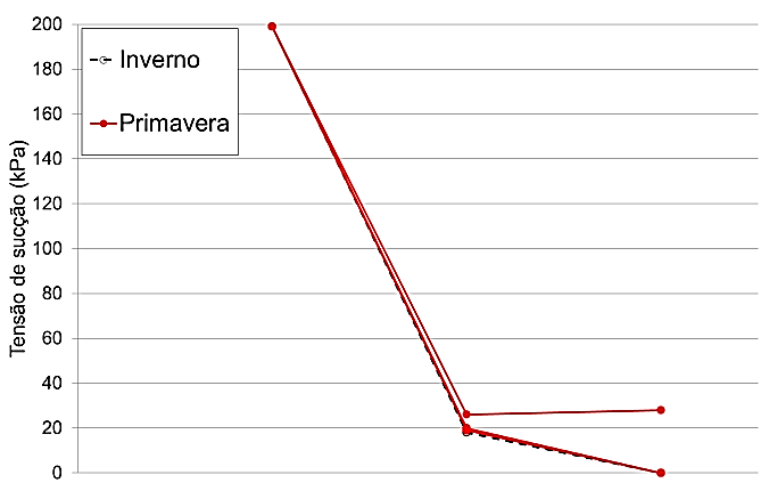

(a)

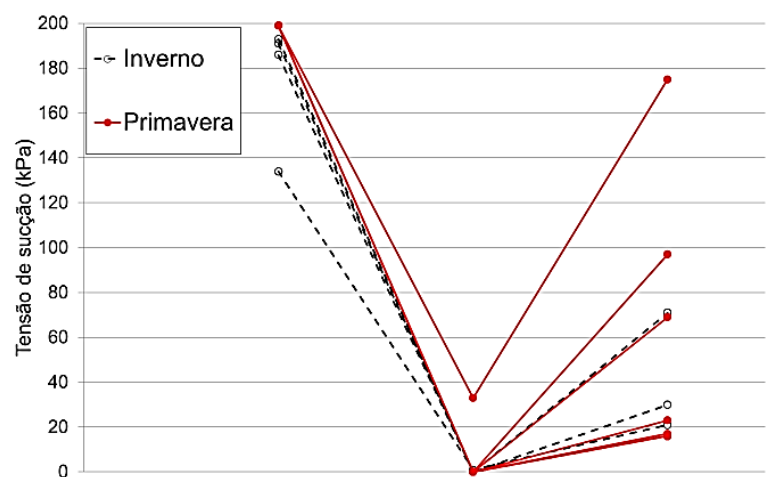

(b)

Uma observação geral desses registros sugere, a princípio, uma tendência mais acentuada de variação nos valores de tensão de sucção na seção da via contendo sublastro granular, em comparação com onde está o sublastro betuminoso, independentemente da localização dos sensores (superfície ou profundidade). Entretanto, analisando-se de forma mais detalhada a Figura 52 percebe-se que, na seção com sublastro betuminoso, as variações de tensão ocorrem quase que 
igualmente para os três pontos avaliados (eixo trilho/dormente, ombro e saia), mas que, excetuando-se uma única leitura, os sensores de superfície localizados no eixo trilho/dormente e ombro mantiveram-se praticamente inalterados para a estrutura com sublastro granular. Ademais, mesmo variando significativamente mais que os outros sensores de superfície, o sensor localizado na saia do trecho com sublastro granular permanece com valores de tensões dentro da mesma faixa registrada no trecho com sublastro betuminoso.

Observando-se as medidas tomadas em profundidade (Figura 53), nota-se que os pontos localizados no eixo trilho/dormente, ou seja, mais próximos do eixo central da via, registram tensões de sucção bem acima daquelas computadas em qualquer outro ponto da estrutura, para todas as campanhas. Comparando-se estes pontos nas duas configurações estruturais de via, percebe-se ainda que, para o trecho com sublastro betuminoso, não houve sequer variação de tensão de sucção nesse ponto. Complementarmente, assim como ocorrido para os sensores de superfície, os valores de tensão de sucção medidos na saia da seção com sublastro granular sofrem maiores e mais frequentes variações no período analisado que qualquer outro ponto localizado em profundidade de ambas as seções.

A partir de tais constatações, pode-se afirmar que, como esperado, o ponto mais distante do eixo central da via, e consequentemente mais desprotegido por possuir menores espessuras de camadas sobrejacentes, é o que mais sofre variações de tensão de sucção ao longo do período analisado, muito provavelmente fruto da variação de umidade por infiltração de água da chuva. Da mesma forma, também se esperava que, comparativamente, este ponto localizado na estrutura contendo sublastro granular sofreria maiores variações que aquele posicionado na estrutura com sublastro betuminoso, considerando singularmente a maior permeabilidade da camada granular.

Fazendo-se uso da escala sugerida pelo fabricante dos sensores para a condição de saturação do solo, todos os pontos analisados na seção com sublastro betuminoso estão consideravelmente úmidos (parcial a totalmente saturado), excetuando-se o ponto localizado em profundidade e no eixo trilho/dormente. Para a estrutura contendo 
sublastro granular, os valores encaixam-se em faixas que vão desde a condição seca até a saturada. Tais constatações, por si só, não são capazes de afirmar que o emprego de sublastro betuminoso impermeabiliza completamente a camada de subleito, evitando que a mesma sofra com variações no seu teor de umidade, mas indicam que a presença da mistura asfáltica mantém essas variações significativamente menores.

Os gráficos da Figura 54 mostram as médias e desvios padrões dos valores obtidos para todos os pontos analisados neste estudo. Verifica-se que existe uma menor variabilidade nas tensões de sucção medidas na camada de subleito do trecho contendo sublastro betuminoso, indicando que tal condição permanece razoavelmente homogênea durante os meses monitorados.

Figura 54. Análise das tensões de sucção medidas nos sensores de (a) superfície e (b) profundidade

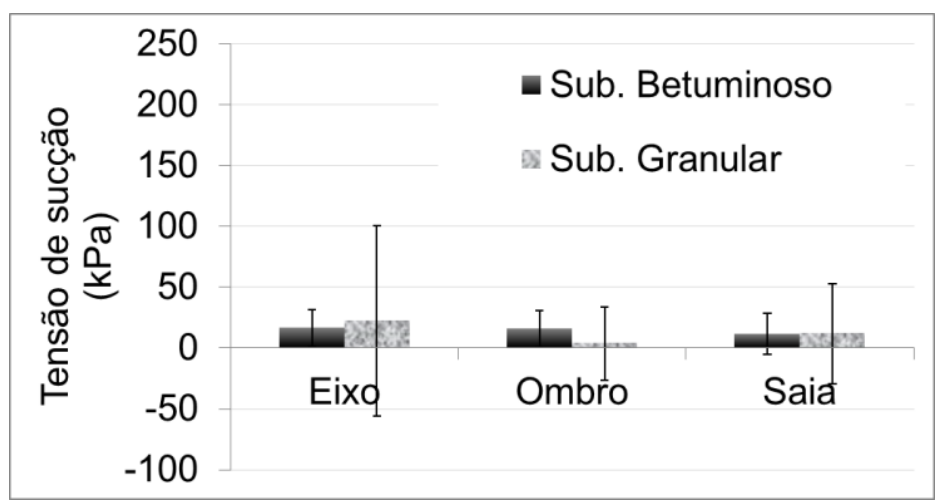

(a)

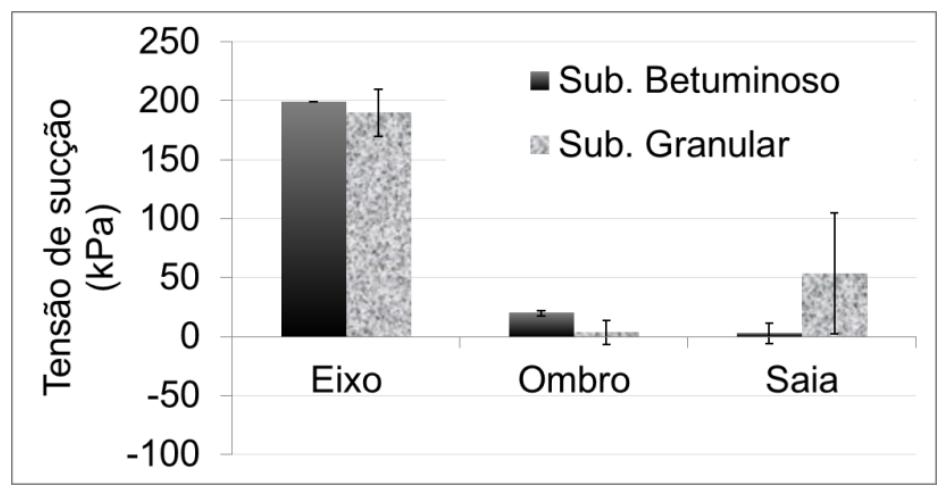

(b)

Ferreira et al. (2011), baseando-se em resultados de simulações termo-hidromecânicas do pavimento ferroviário, afirmam que a amplitude das deformações encontradas no topo da camada de subleito é proporcional à amplitude da oscilação 
das tensões de sucção atuantes nesta camada. Dessa forma, a depender das características do solo e da susceptibilidade à contração e expansão deste quando da variação do teor de umidade, dentre outros fatores, pode-se dizer que as menores amplitudes de deformação são esperadas para a seção da via que contém sublastro betuminoso. Para regiões onde o assentamento diferencial da plataforma constitui-se como um problema constante, a solução empregada pode minimizar tais danos. A camada de sublastro granular, por sua vez, como esperado, desempenha a função filtro e possibilita a passagem de água, o que não pode ser considerado em sua totalidade uma característica negativa e relacionada a problemas na via.

\subsection{Dados oriundos das medidas de acompanhamento}

Medidas de deslocamentos

As medidas de deslocamento foram tomadas em um total de quatro campanhas, com registros referentes à passagem de composições carregadas e descarregadas. Um exemplo de sinal registrado por meio do Dispositivo de Medição de Deslocamentos pode ser observado na Figura 55. Os dados foram gerados com a passagem de uma composição composta por duas locomotivas de 30 ton/eixo e seis vagões vazios de 6,3 ton/eixo. O registro foi feito na seção contendo sublastro betuminoso, na campanha ocorrida em agosto de 2017, a uma velocidade de $20 \mathrm{~km} / \mathrm{h}$. Os valores médios entre as amplitudes máximas medidas (no patim do trilho) foram de 4,6 mm para as locomotivas e de $2,7 \mathrm{~mm}$ para os vagões. 
Figura 55. Sinal de deslocamento registrado na seção com sublastro betuminoso

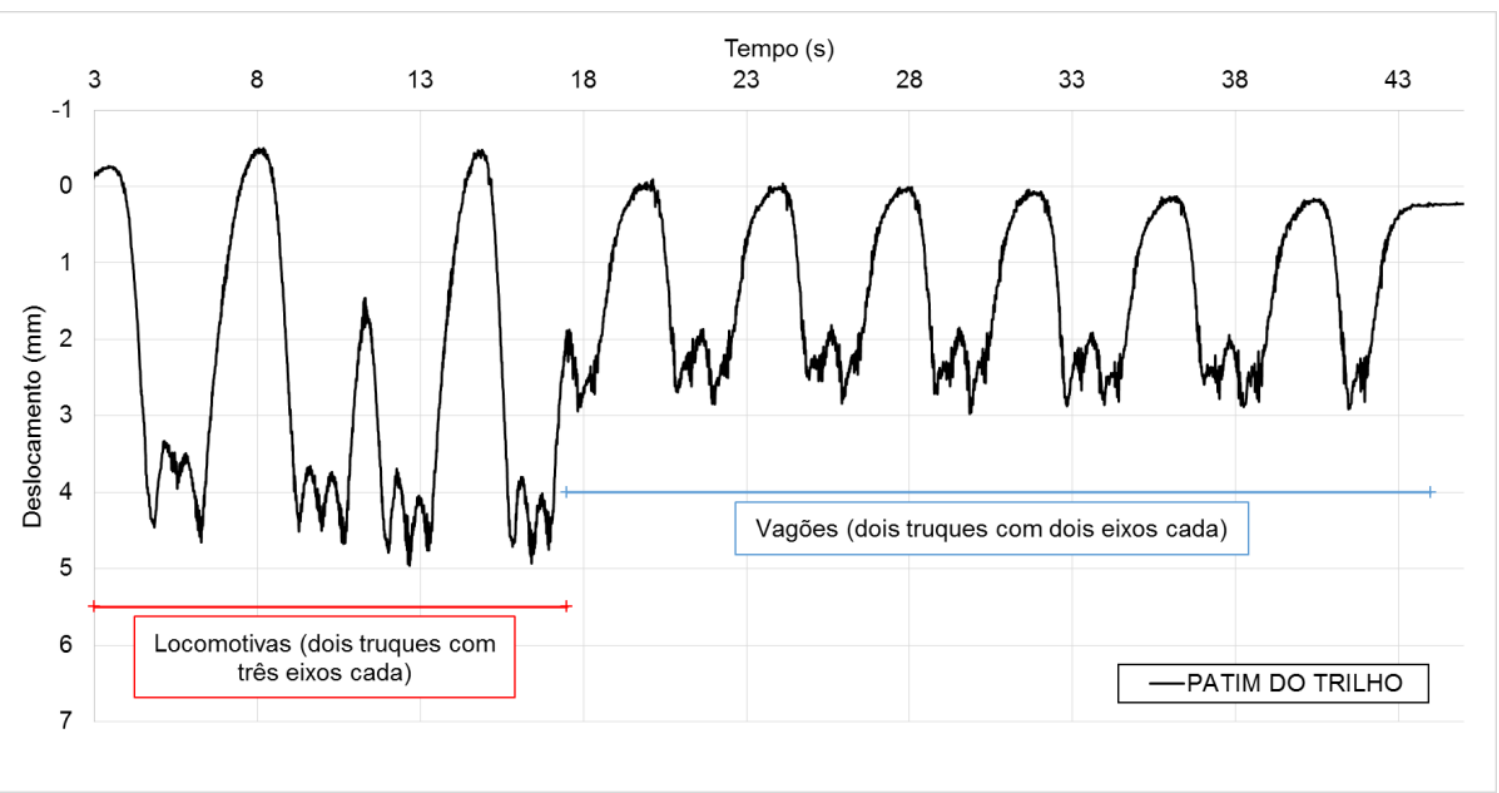

Os deslocamentos médios para as seções com sublastro betuminoso, sublastro granular e trecho sem intervenção são mostrados na Tabela 4. Optou-se por calcular o deslocamento médio com base nas amplitudes máximas medidas com a passagem das locomotivas, uma vez que estas variavam minimamente quanto à carga por eixo e a características tais como distância entre os centros dos truques e entre os eixos pertencentes a cada truque.

Tabela 4. Deslocamentos médios medidos com base nas solicitações dinâmicas das locomotivas

\begin{tabular}{|c|c|c|c|c|c|}
\hline Data & Descrição & Seção & $\begin{array}{l}\text { Carga por eixo } \\
\text { média (ton) }\end{array}$ & $\begin{array}{c}\text { MTBT } \\
\text { acumulado }\end{array}$ & $\begin{array}{l}\text { Deslocamentos } \\
\text { médios }(\mathrm{mm})\end{array}$ \\
\hline \multirow{3}{*}{ Agosto/2017 } & \multirow{3}{*}{$\begin{array}{c}\text { Composição } \\
\text { carregada }\end{array}$} & Betuminoso & \multirow{3}{*}{31} & \multirow{3}{*}{1,0} & 4,45 \\
\hline & & Granular & & & 5,47 \\
\hline & & Sem intervenção & & & 4,44 \\
\hline \multirow{3}{*}{ Outubro/2017 } & \multirow{3}{*}{$\begin{array}{l}\text { Composição } \\
\text { carregada }\end{array}$} & Betuminoso & \multirow{3}{*}{30} & \multirow{3}{*}{1,7} & 4,86 \\
\hline & & Granular & & & 3,78 \\
\hline & & Sem intervenção & & & 4,24 \\
\hline \multirow{3}{*}{ Novembro/2017 } & \multirow{3}{*}{$\begin{array}{c}\text { Composição } \\
\text { carregada }\end{array}$} & Betuminoso & \multirow{3}{*}{30} & \multirow{3}{*}{2,3} & 6,67 \\
\hline & & Granular & & & 3,71 \\
\hline & & Sem intervenção & & & 3,75 \\
\hline \multirow{3}{*}{ Dezembro/2017 } & \multirow{3}{*}{$\begin{array}{c}\text { Composição } \\
\text { carregada }\end{array}$} & Betuminoso & \multirow{3}{*}{29} & \multirow{3}{*}{2,6} & 2,95 \\
\hline & & Granular & & & 3,54 \\
\hline & & Sem intervenção & & & 3,98 \\
\hline
\end{tabular}

Ressalta-se que, entre as campanhas de outubro e novembro ocorreu uma atividade mecanizada de socaria em todas as seções analisadas. Buscando-se evitar o 
rompimento de sensores instalados, uma área que compreendia três dormentes consecutivos foi isenta do processo de socaria no trecho contendo sublastro betuminoso. Durante a campanha de novembro, por limitações técnicas, a medida de deslocamento foi tomada em um dos referidos dormentes, o que explica 0 deslocamento excessivo medido para a seção com sublastro betuminoso nesta campanha em particular.

Acredita-se que a região isenta da socaria sofreu recalque da camada de lastro como consequência da vibração e impacto gerados pela atividade nas regiões próximas, além de sofrer com o realinhamento da grade ferroviária a parâmetros geométricos predefinidos, sem que houvesse reajuste da camada de lastro sob os dormentes e reposição de material faltante. Assim, ao se medirem deslocamentos no patim do trilho nesse local é provável que tenha sido registrado um ponto onde existe um "gap" entre a base do dormente e a camada de lastro, proporcionando maiores magnitudes de deslocamentos. A Figura 56 traz o gráfico referente às medidas de deslocamento por acúmulo de tráfego em MTBT, com a linha tracejada na vertical indicando o momento em que a socaria foi realizada, e os valores mínimo e máximo desejáveis de deslocamentos recomendados pela AREMA (2013). Com esta figura torna-se mais notável a discrepância entre os valores de deslocamento medidos no trecho com sublastro betuminoso logo após a socaria e as demais campanhas.

Figura 56. Deslocamentos médios por acúmulo de tráfego

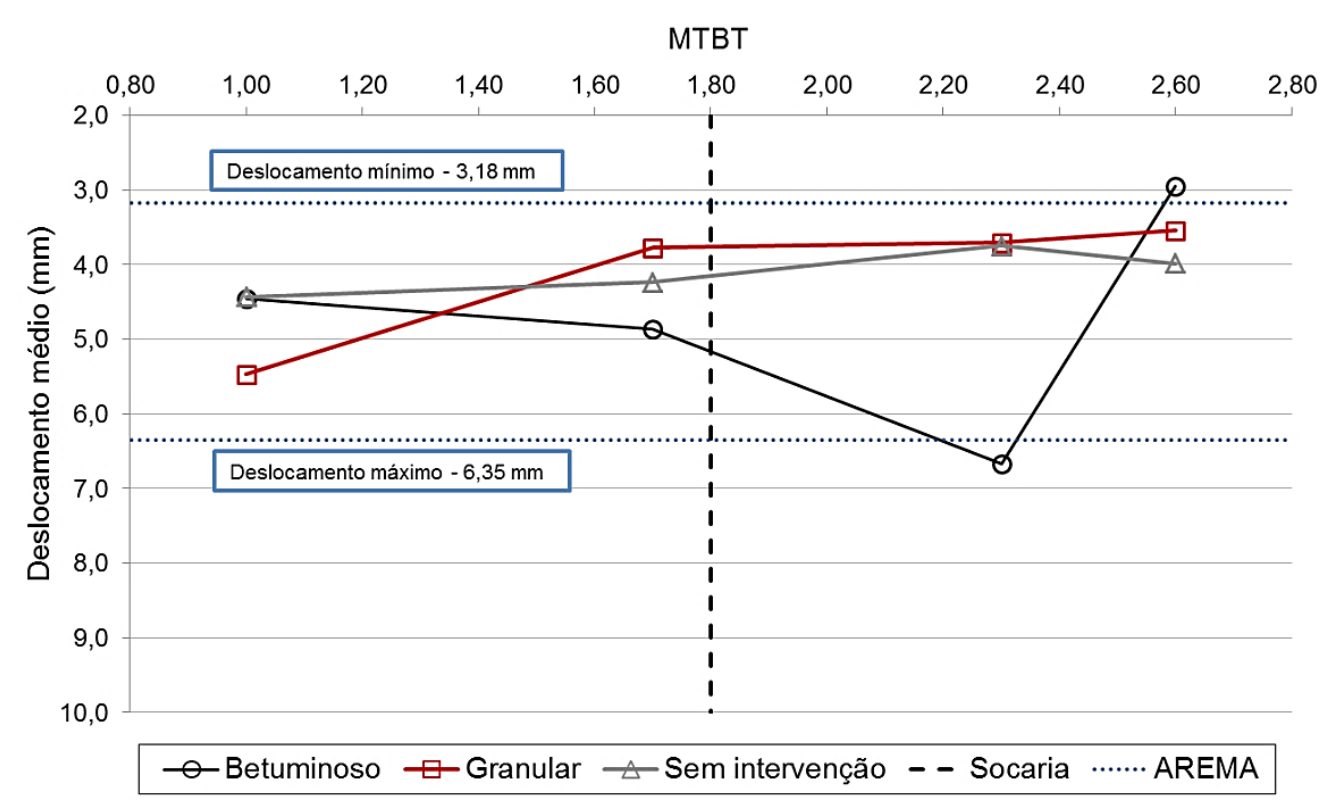


Analisando-se ainda a Figura 56, pode-se perceber o surgimento de uma tendência de redução de deslocamentos no trecho com sublastro betuminoso em detrimento das demais seções (com sublastro granular e sem intervenção) na campanha derradeira. As duas primeiras campanhas não registraram significativamente a influência do uso de uma camada de sublastro betuminoso na magnitude de deslocamentos medidos, o que, mais uma vez, confirma a premissa de que a resposta mecânica global da via permanente está atrelada ao comportamento de diversos componentes e materiais, de maneira individual e em conjunto, como consequência das solicitações de tráfego e climáticas.

O acompanhamento periódico dos trechos experimentais, desde a sua construção, e o estudo do comportamento dos materiais que os compõem podem elucidar alguns questionamentos referentes aos deslocamentos medidos. Como mencionado anteriormente, a espessura da camada de lastro possui uma defasagem de cerca de $40 \%$ entre a seção com sublastro betuminoso e a com sublastro granular, enquanto a seção sem intervenção é caracterizada por uma camada de lastro mais espessa que a última, porém bastante colmatada, o que pode ter implicado em uma resposta mais rígida desta.

\section{Determinação do módulo de via}

O módulo de via, $u$, foi calculado através da Equação [6], formulada por Talbot (1918). A carga média adotada foi a das locomotivas, assim como utilizado no cálculo dos deslocamentos médios da seção anterior. Os valores de módulo de elasticidade e momento de inércia considerados para o trilho TR 57 foram $E=2,10 \times 10^{8}(\mathrm{kPa})$ e $\mathrm{I}=2,73 \cdot 10^{-5}\left(\mathrm{~m}^{4}\right)$, respectivamente. A Tabela 5 fornece os resultados calculados de módulo de via, $u$, e a Figura 57 ilustra a variação destes módulos à medida que a via acumula tráfego nos trechos com sublastro betuminoso, sublastro granular e sem intervenção. 
Tabela 5. Valores de módulo de via, $u$

\begin{tabular}{|c|c|c|c|c|c|c|}
\hline Data & Descrição & Seção & $\begin{array}{l}\text { Carga por eixo } \\
\text { média (ton) }\end{array}$ & $\begin{array}{c}\text { MTBT } \\
\text { acumulado }\end{array}$ & $\begin{array}{l}\text { Delocamentos } \\
\text { médios }(\mathrm{mm})\end{array}$ & $\begin{array}{c}\text { Módulo de via, } \\
\text { u (MPa) }\end{array}$ \\
\hline \multirow{3}{*}{ Agosto/2017 } & \multirow{3}{*}{$\begin{array}{c}\text { Composição } \\
\text { carregada }\end{array}$} & Betuminoso & \multirow{3}{*}{31} & \multirow{3}{*}{1,0} & 4,45 & 14,81 \\
\hline & & Granular & & & 5,47 & 11,25 \\
\hline & & Sem intervenção & & & 4,44 & 14,89 \\
\hline \multirow{3}{*}{ Outubro/2017 } & \multirow{3}{*}{$\begin{array}{c}\text { Composição } \\
\text { carregada }\end{array}$} & Betuminoso & \multirow{3}{*}{30} & \multirow{3}{*}{1,7} & 4,86 & 13,19 \\
\hline & & Granular & & & 3,78 & 18,45 \\
\hline & & Sem intervenção & & & 4,24 & 15,83 \\
\hline \multirow{3}{*}{ Novembro/2017 } & \multirow{3}{*}{$\begin{array}{c}\text { Composição } \\
\text { carregada }\end{array}$} & Betuminoso & \multirow{3}{*}{30} & \multirow{3}{*}{2,3} & 6,67 & 8,64 \\
\hline & & Granular & & & 3,71 & 18,92 \\
\hline & & Sem intervenção & & & 3,75 & 18,66 \\
\hline \multirow{3}{*}{ Dezembro/2017 } & \multirow{3}{*}{$\begin{array}{c}\text { Composição } \\
\text { carregada }\end{array}$} & Betuminoso & \multirow{3}{*}{29} & \multirow{3}{*}{2,6} & 2,95 & 25,69 \\
\hline & & Granular & & & 3,54 & 20,10 \\
\hline & & Sem intervenção & & & 3,98 & 17,18 \\
\hline
\end{tabular}

Figura 57. Módulo de via, u, por acúmulo de tráfego

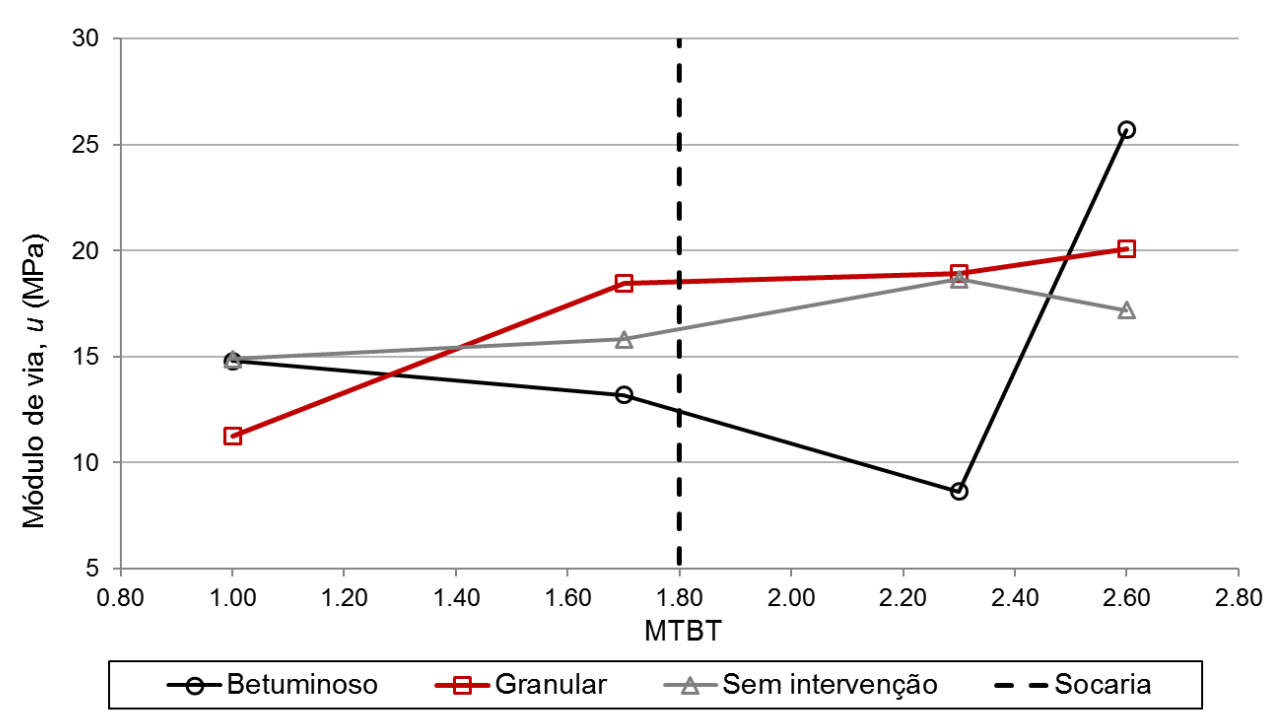

Os valores obtidos para o trecho sem intervenção são da mesma ordem dos registrados por Costa (2016) para uma via com condição de lastro colmatado e dormentes de madeira (entre 17 e $28 \mathrm{MPa}$ ). As demais seções, no entanto, apresentaram módulo de via abaixo do estabelecido pela AREMA (2013) para vias com dormentes de madeira (21 MPa), exceto na última campanha, na seção com sublastro betuminoso. Tal comportamento era esperado, considerando-se que estas seções passaram por renovações recentes e ainda não tinham sido submetidas a solicitações de tráfego de magnitudes significativas para maior densificação da camada de lastro. Para ambas as seções, houve um acréscimo de, aproximadamente, $70 \%$ no valor de módulo após 1,6 MTBT acumulado, entre a primeira e a última campanha. Os valores de módulo de via no trecho com sublastro betuminoso foram 
cerca de $30 \%$ superiores aos registrados na seção com sublastro granular, também nestas campanhas (Tabela 5). Pode-se considerar, portanto, que o emprego de sublastro betuminoso pode ter influenciado no processo de densificação da camada de lastro, fornecendo um suporte mais rígido e homogêneo comparativamente à camada de brita graduada simples, colaborando para o assentamento dos agregados.

\section{Medidas de parâmetros geométricos}

As Figura 58 a Figura 60 apresentam os valores médios e desvios padrões obtidos para os parâmetros de variação de bitola, inclinação e empeno $(10 \mathrm{~m})$ medidos trimestralmente nas seções contendo sublastro betuminoso, sublastro granular e sem intervenção. Já a Figura 61, mostra, graficamente, o registro das campanhas para o parâmetro de inclinação em todas as seções.

Figura 58. Análise das medidas de bitola

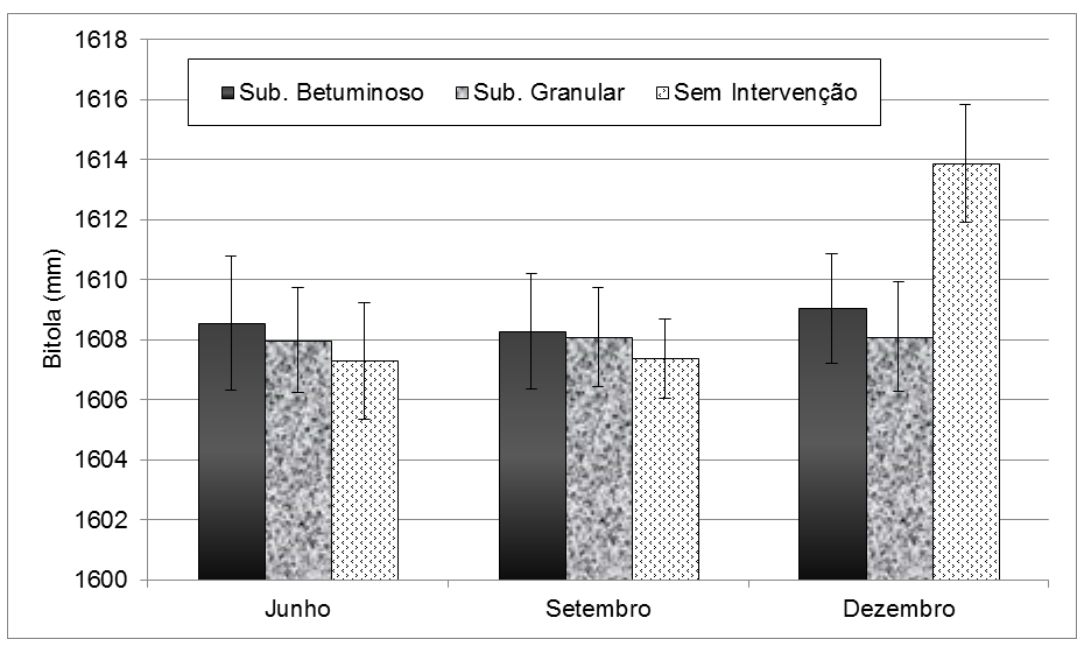

Observando-se isoladamente os resultados em termos de bitola (Figura 58), nota-se que, durante as duas primeiras campanhas, as três seções não apresentaram grandes variações deste parâmetro, sendo mantidas as condições geométricas no trecho como um todo próximas à média. Este desempenho era esperado para uma região recémrenovada e com acúmulo de tráfego dentro da faixa de densificação da camada de lastro (aproximadamente 1 MTBT acumulado). Durante a terceira campanha, após a atividade de socaria ocorrida no mês de outubro, a seção que não teve intervenção apresentou um destacado alargamento de bitola, indicando uma possível queda na 
resistência lateral, enquanto as demais se mantiveram dentro da faixa de variação medida anteriormente, e em congruência entre si. Uma das causas para essa alteração pode ter relação com o índice pluviométrico (mais elevado nesta campanha que nas demais - ANEXO A) e à condição estrutural da via nesta seção, caracterizada pela ausência de sublastro e por camada de lastro colmatada. Esta situação favorece o aparecimento do fenômeno conhecido como bombeamento de finos, quando o lastro desempenha pobremente sua função drenante e o escoamento da água da chuva para os devidos dispositivos de drenagem é dificultada. Por constituir-se um trecho em curva, onde o fator de impacto da roda nos trilhos é mais significativo, pode-se considerar preocupante sinais de alargamento e estreitamento de bitola abruptos tais como os observados. Ademais, a campanha de medição de deslocamentos concomitante à geométrica para o mês de dezembro apontou este trecho como o de maior deslocamento médio dentre os analisados e, por conseguinte, menor valor de módulo de via.

Figura 59. Análise das medidas de inclinação

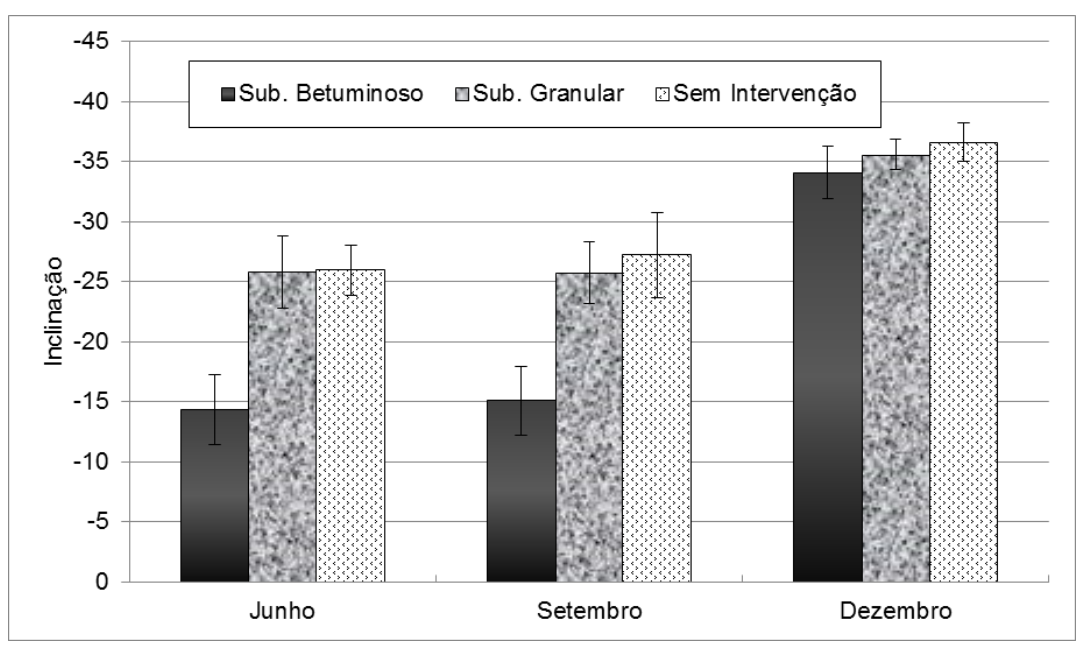

A Figura 59 traz as medidas de inclinação nas seções estudadas e apresenta um aspecto interessante quanto à superelevação nos trechos e quanto ao papel desempenhado pela correção geométrica pela socaria. Percebe-se que, na terceira campanha, as médias crescem quase que proporcionalmente e apontam o pertencimento das três seções a um trecho mais extenso de entrada (ou saída) de uma curva. 
Uma análise mais atenta dos resultados das medidas de inclinação e dos valores de deslocamentos médios medidos (Figura 56) das três seções, nas campanhas de agosto e outubro, trazem aspectos relevantes para a compreensão da relação entre parâmetros geométricos e desempenho mecânico da via permanente. A Figura 59 aponta um notável degrau nas medidas de inclinação média da seção com sublastro betuminoso em comparação com as demais, demonstrando a necessidade do material rodante de vencer um degrau de cerca de $40 \%$ de diferença entre as superelevações existentes quando trafegando na linha. Da mesma forma, os deslocamentos médios registrados para a seção com sublastro betuminoso nas campanhas anteriores apontam valores superiores aos das seções com sublastro granular e sem intervenção, que mantém valores similares entre si, assim como nas medidas de superelevação.

Não se pode afirmar que a incompatibilidade geométrica possa ser a causa maior de comportamentos mecânicos indesejados, e vice-versa, no entanto há de se atentar para a indicação de que a alteração significativa de posicionamento da grade ferroviária, atrelada a solicitações de alta magnitude (caso da PG-RS) sobrecarregam os componentes e camadas da via como um todo. Quando somados a déficits estruturais das camadas, sejam por espessuras não compatíveis ou baixa capacidade de suporte dos materiais que as compõem, dentre outros, os impactos gerados nos locais com desvios de parâmetros geométricos podem causar acelerada degradação e desestabilização (primeiramente da camada de lastro), refletindo-se em maiores deslocamentos na via. Nota-se que tal constatação é relevante, baseando-se nas medidas de deslocamento após a pré-estabilização da condição geométrica da via (socaria) na seção com sublastro betuminoso. A leitura tomada na região não restaurada da seção com sublastro betuminoso, em novembro, apresentou deslocamento médio relativamente elevado $(6,7 \mathrm{~mm}) \mathrm{e}$, em dezembro, quando tomada na região restaurada, teve uma redução de mais de 50\% (3,0 mm). Cabe mencionar que ambos os valores se referem às leituras após a correção da superelevação do trecho com sublastro betuminoso. 
Figura 60. Análise das medidas de empeno (10 m)

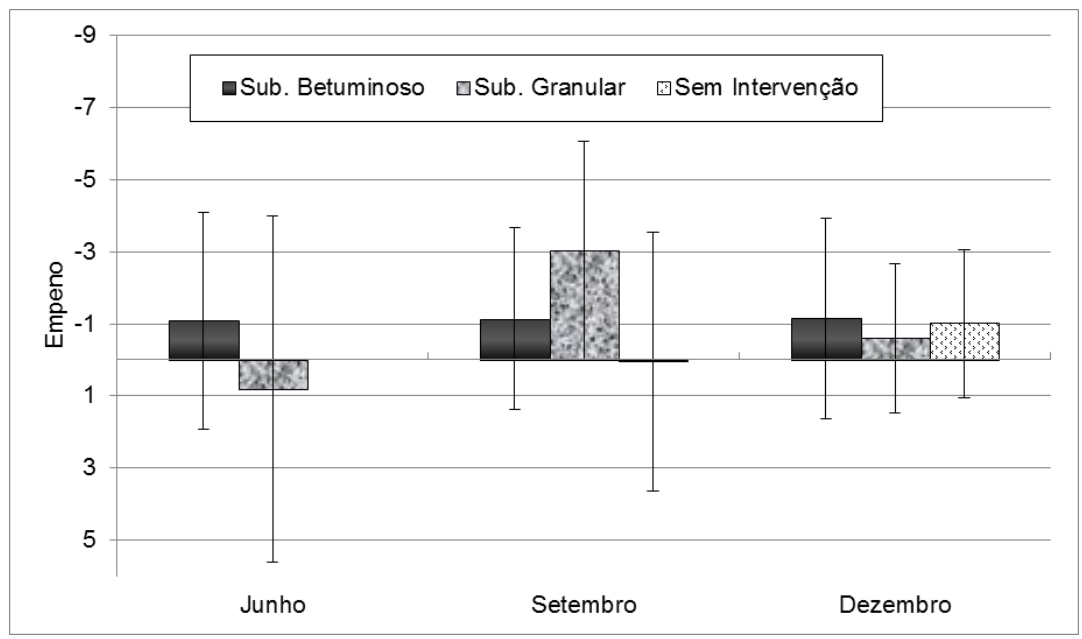

A Figura 60 mostra o empeno relativo à corda de $10 \mathrm{~m}$. Percebe-se, por meio desta, que a seção com sublastro betuminoso mantém a sua condição sem oscilações de variação ao longo de todas as campanhas, ao passo que a seção com sublastro granular altera-se. Avaliações mais detalhadas deste parâmetro tornam-se difíceis frente à reduzida extensão dos trechos experimentais (o trecho sem intervenção possui apenas $9 \mathrm{~m}$ de extensão, sendo menor que a própria distância tomada como referência, entre os pontos para aferição deste parâmetro).

Figura 61. Representação gráfica das medidas de inclinação nos trechos contendo (a) sub. betuminoso, (b) sub. granular e sem intervenção

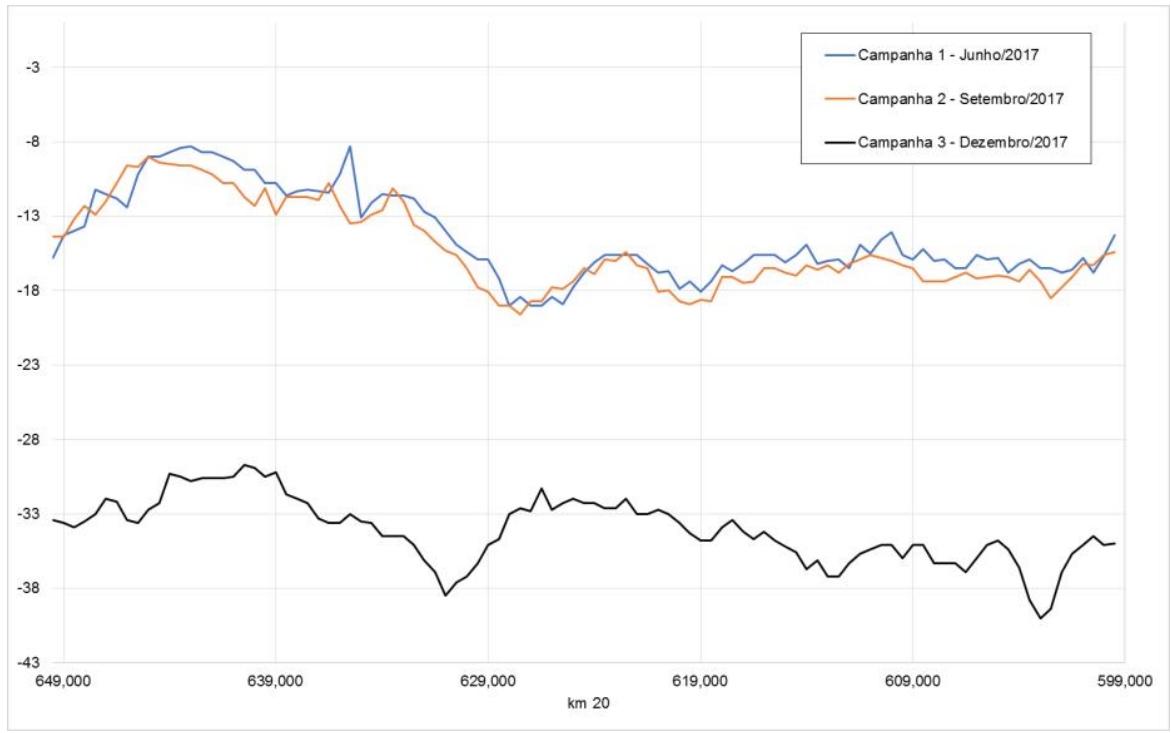

(a) 


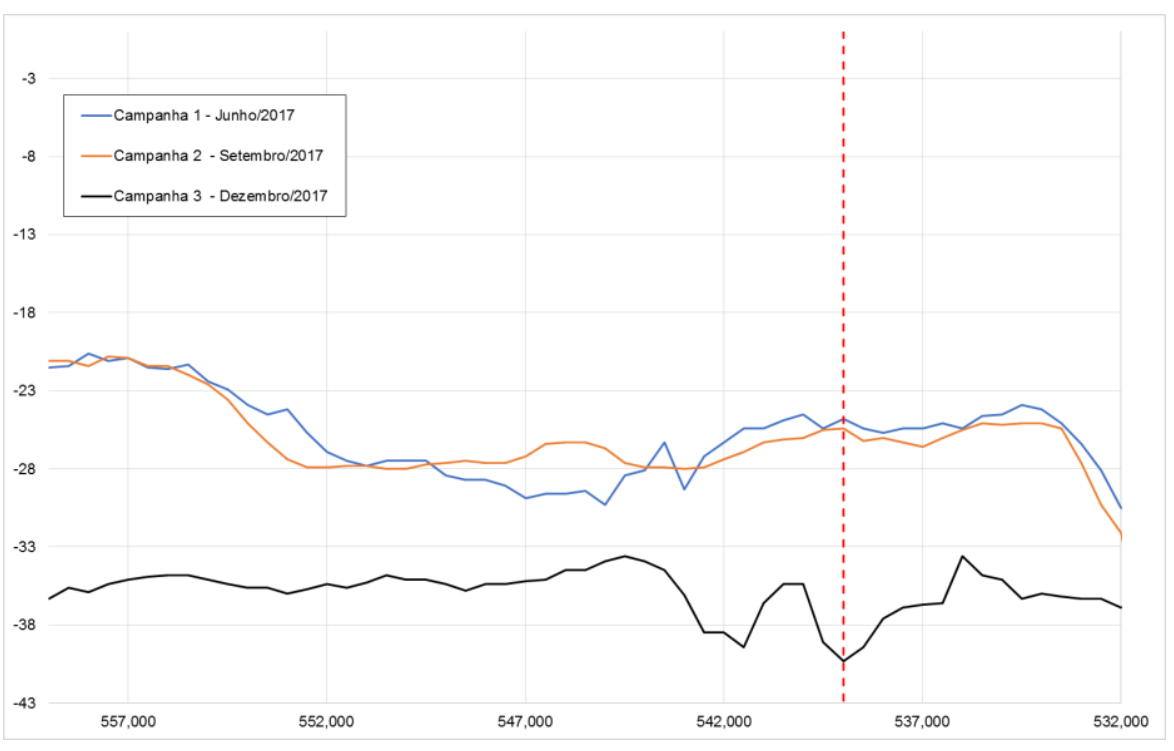

(b)

A Figura 61 ilustra os registros obtidos com o equipamento Trolley Amber a cada 0,5 $\mathrm{m}$ ao longo da via. No gráfico superior podem-se observar os registros de inclinação na seção com sublastro betuminoso, enquanto no inferior vê-se o mesmo para as seções com sublastro granular e sem intervenção, separados pela linha vermelha tracejada na vertical (trecho sem intervenção com menor extensão, à direita). Nesta figura, nota-se que cada seção, individualmente, manteve um comportamento bastante homogêneo nas duas primeiras campanhas, com pequenas amplitudes de variação entre as inclinações medidas. A seção contendo sublastro betuminoso possuía, no entanto, inclinações destacadamente menores que nos demais trechos, mas que se mantiveram durante o período analisado. Com a atividade de socaria, esta variação foi minimizada e, assim como observado nas demais campanhas, espera-se que a seção mantenha as condições geométricas as quais foi realocada sem alterações consideráveis em função do acúmulo de tráfego na linha.

\subsection{Caracterização física e mecânica dos materiais}

Solo do subleito

A curva granulométrica obtida por peneiramento e sedimentação (Figura 62) juntamente com os índices de plasticidade do solo (Tabela 6) classificaram o material do subleito como sendo do tipo A-4, segundo a Highway Research Board, adotada 
pela AASHTO (American Association of State Highway and Transportation Officials). Esta engloba solos do tipo siltoso, com tendência de comportamento geral fraco a pobre como material de subleito. Segundo o Sistema Unificado de Classificação dos Solos (SUCS), o material enquadra-se na categoria ML ou OL, ou seja, material do tipo silte / argila orgânica ou silte orgânico. Estes grupos caracterizam-se por solos com mais da metade do material menor que a abertura de malha da peneira \#200 (solos de granulação fina) e com altos índices de plasticidade (limite de liquidez menor que 50).

Figura 62. Curva granulométrica do solo do subleito

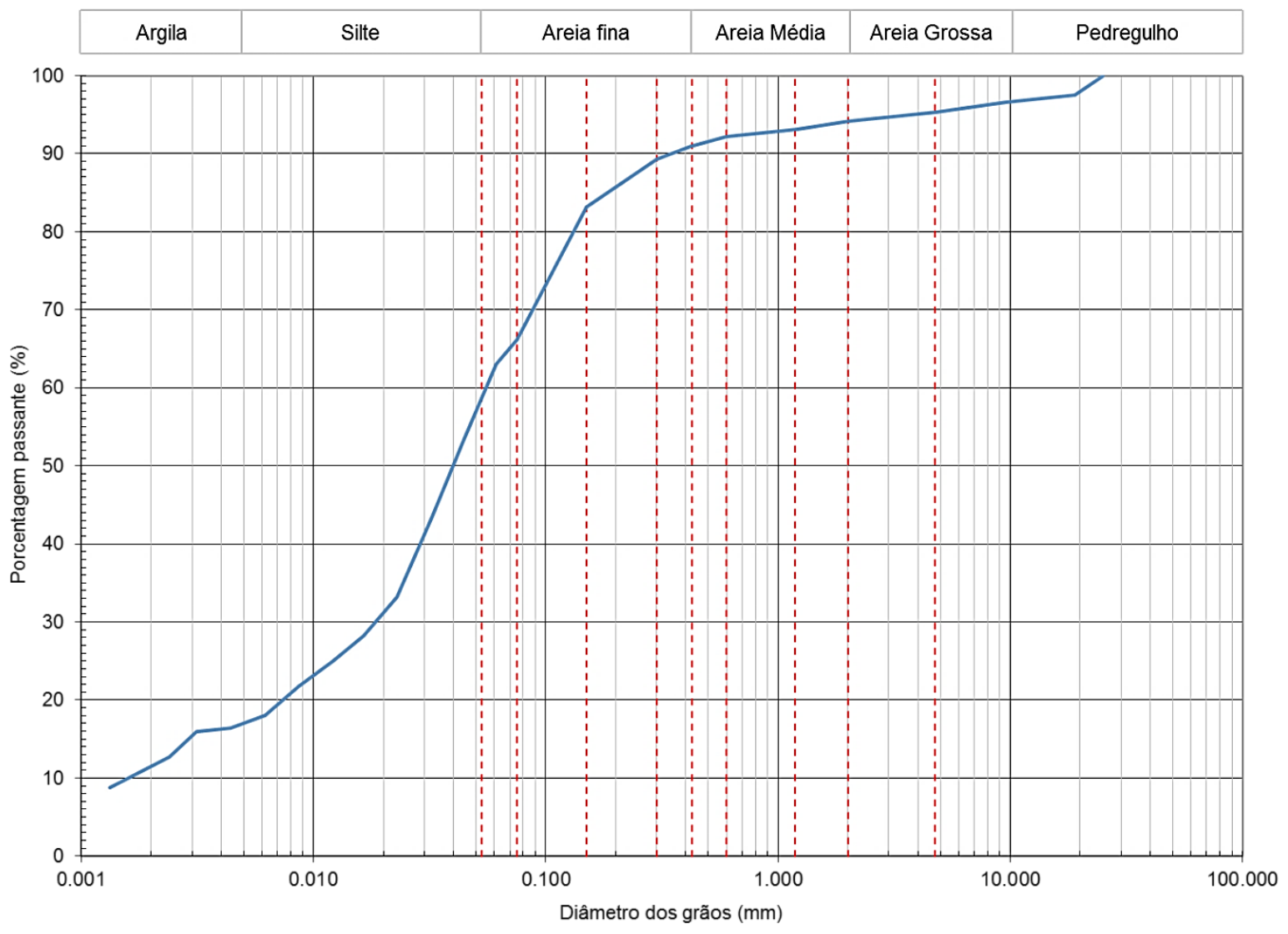

Tabela 6. Índices de plasticidade e classificação HRB e SUCS do solo

\begin{tabular}{cccccccc}
\hline LL & LP & $\mathbb{P}$ & \multicolumn{3}{c}{$\%$ passante na \# } & Class & Class \\
$\%$ & $\%$ & $\%$ & 10 & 40 & 200 & HRB & SUSC \\
\hline 32,76 & 28,52 & 4,24 & 94,11 & 90,93 & 66,17 & A-4 & ML ou OL \\
\hline
\end{tabular}

Fazendo-se uso do Método de Identificação Expedita para solos tropicais, o solo do subleito foi classificado como sendo não laterítico siltoso / não laterítico arenoso (NS'/NA') pelo ensaio com amostras pequenas (anéis com 20 mm de diâmetro). Para 
amostras grandes, em anéis com $35 \mathrm{~mm}$ de diâmetro, o material apresentou capacidade média a baixa de contração e expansão, sendo classificado como não laterítico siltoso (NS'). Os parâmetros medidos em ambos os ensaios de pastilha podem ser visualizados na Tabela 7 .

Tabela 7. Parâmetros obtidos pelo Método de Identificação Expedita

\begin{tabular}{ccc}
\hline $\begin{array}{c}\text { Contração } \\
\mathrm{mm}\end{array}$ & $\mathrm{c}^{\prime}$ & $\begin{array}{c}\text { Penetração } \\
\mathrm{mm}\end{array}$ \\
\hline 0,67 & 1,04 & 5 \\
\hline
\end{tabular}

(a) Pastilha pequena

\begin{tabular}{ccccc}
\hline $\begin{array}{c}\text { Contração Expansão } \\
\%\end{array}$ & $\begin{array}{c}\text { Índice de } \\
\text { reabsorção } \\
\text { de água }\end{array}$ & $\begin{array}{c}\text { Penetração } \\
\mathrm{mm}\end{array}$ & $\begin{array}{c}30 \mathrm{~g} \\
\mathrm{~mm}\end{array}$ \\
\hline 2,7 & 2,61 & 0,86 & 6,2 & 11,5 \\
\hline
\end{tabular}

(b) Pastilha grande

Pela metodologia MCT obteve-se a classificação NS' (não laterítico siltoso), em congruência com os demais resultados anteriormente apresentados. Os parâmetros obtidos através de uma série de ensaios com corpos de prova cilíndricos compactados em tamanho reduzido $(50 \mathrm{~mm})$ podem ser observados na Tabela 8.

Tabela 8. Parâmetros M-MCV e classificação MCT

\begin{tabular}{ccccc}
\hline$c^{\prime}$ & $d^{\prime}$ & $e^{\prime}$ & $\begin{array}{c}P i \\
\%\end{array}$ & $\begin{array}{c}\text { Class } \\
\text { MCT }\end{array}$ \\
\hline 1,48 & 1,89 & 2,37 & 275 & NS' $^{\prime}$ \\
\hline
\end{tabular}

Resultados dos ensaios de difração por raio $\mathrm{X}$ identificaram a presença de quartzo $\left(\mathrm{SiO}_{2}\right)$, caulinita $\left(\mathrm{Al}_{2}\left(\mathrm{Si}_{2} \mathrm{O}_{5}\right)(\mathrm{OH})_{4}\right)$, muscovita $\left(\mathrm{KAl}_{3} \mathrm{Si}_{3}(\mathrm{OH})_{2} \mathrm{O}_{10}\right)$, microlínio $\left(\mathrm{KAISi}_{3} \mathrm{O}_{8}\right)$, rectorita $\left(\mathrm{K}_{1,2} \mathrm{Al} \mathrm{SSi}_{8} \mathrm{O}_{20}(\mathrm{OH})_{4} 4 \mathrm{H}_{2} \mathrm{O}\right)$, gibbsita $\left(\mathrm{Al}(\mathrm{OH})_{3}\right)$ e zeólita $\left(\mathrm{Al}\left(\mathrm{PO}_{4}\right)\right)$. Além disso, acusou possível presença de anfibólio $\left(\mathrm{Al}_{3,2} \mathrm{Ca}_{3,4} \mathrm{Fe}_{4,02} \mathrm{~K}_{0,6} \mathrm{Mg}_{6} \mathrm{NaSi}_{12,8} \mathrm{O}_{44}(\mathrm{OH})_{4}\right)$ e paligorskite $\left(\left(\mathrm{Mg}_{0,669} \mathrm{Al}_{0,331}\right)_{4}\left(\mathrm{Si}_{4} \mathrm{O}_{10}\right)_{2}(\mathrm{OH})_{2}\left(\mathrm{H}_{2} \mathrm{O}\right)_{8}\right)$ nas duas amostras ensaiadas (fração de solo passante na peneira de abertura 2,00 mm e fração de solo passante na peneira de abertura $0,074 \mathrm{~mm}$ ). A presença de caulinita corrobora com a característica não expansiva detectada no ensaio expedito da pastilha e reforça a necessidade de classificação de solos nacionais por metodologias que considerem características particulares dos solos tropicais, reconhecidamente possuidores de grandes quantidades de argilominerais na sua composição. 
A curva de compactação característica do solo do subleito realizada em laboratório à energia Proctor normal tem seu ponto máximo definido pelo par de valores: massa específica aparente seca máxima de $1,67 \mathrm{~g} / \mathrm{cm}^{3}$ e umidade ótima de $18,5 \%$. Teores de umidade de campo obtidos de amostras de solo retiradas durante a execução dos trechos experimentais apontam que a camada de subleito foi compactada no ramo úmido, em ambos os casos. Para o trecho com sublastro betuminoso, o teor de umidade na construção foi de $26,4 \%$, enquanto que para o trecho com sublastro granular este valor foi de $36,9 \%$.

Os resultados de módulo de resiliência obtidos através do ensaio triaxial de carga repetida com influência da tensão de confinamento e desviadora podem ser visualizados na Figura 63. A energia de compactação foi a do Proctor normal e a umidade de moldagem obtida, a posteriori, foi de $20,9 \%$. Comparando os valores de módulo de resiliência para tensão de confinamento e desviadora de 0,1 $\mathrm{MPa}$, têm-se valores de $68 \mathrm{MPa}$ e $61 \mathrm{MPa}$, respectivamente.

Figura 63. Módulo de resiliência do solo do subleito
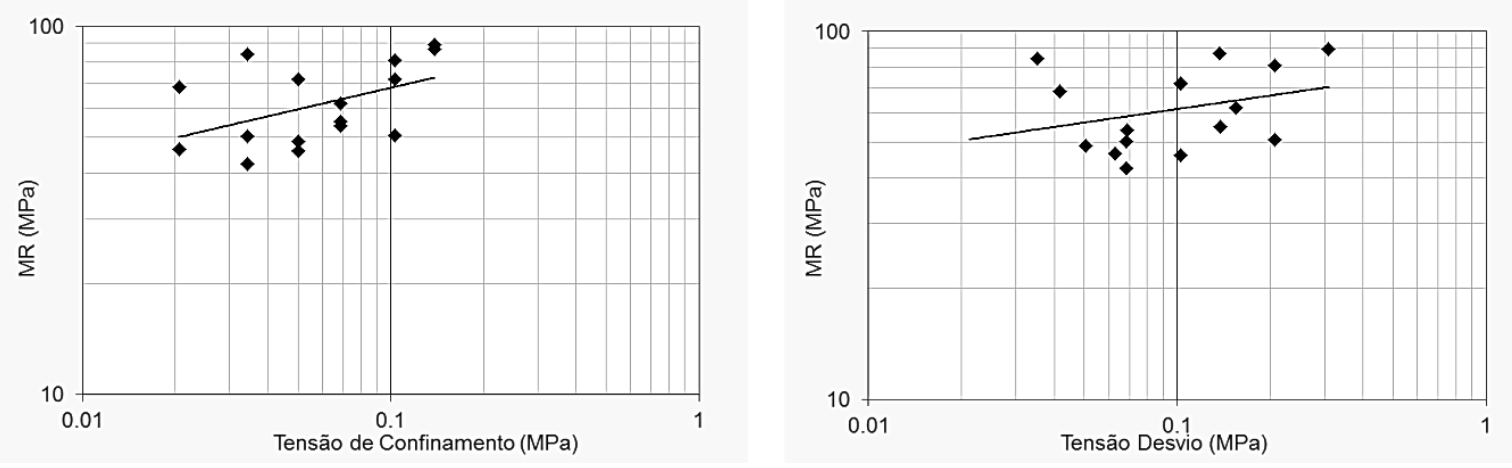

Os corpos de prova utilizados para obtenção da curva de retenção de água do solo foram moldados à energia normal, em tamanho miniatura, e com os teores de umidade descritos na Tabela 9, onde $\Delta \mathrm{w}$ é o desvio de umidade (\%), w é o teor de umidade (\%) e $\gamma_{d}$ é o peso específico aparente seco $\left(\mathrm{g} / \mathrm{cm}^{3}\right)$. 
Tabela 9. Características de moldagem de corpos de prova miniatura para obtenção da curva de retenção

\begin{tabular}{ccccc}
\hline $\begin{array}{c}\text { Corpo de } \\
\text { prova }\end{array}$ & $\begin{array}{c}\Delta \mathrm{w} \\
\text { especificado } \\
(\%)\end{array}$ & $\begin{array}{c}\mathrm{w} \text { de } \\
\text { moldagem } \\
(\%)\end{array}$ & $\begin{array}{c}\Delta \mathrm{w} \text { real } \\
(\%)\end{array}$ & $\begin{array}{c}\mathrm{Yd} \\
\left(\mathrm{g} / \mathrm{cm}^{3}\right)\end{array}$ \\
\hline CP 1 & 0 & $18,50 \%$ & $-0,12$ & 1,5722 \\
\hline CP 2 & +2 & $20,50 \%$ & $+1,60$ & 1,5895 \\
\hline CP 3 & -2 & $16,50 \%$ & $-2,24$ & 1,5083 \\
\hline
\end{tabular}

Os três corpos de prova foram levados à saturação, uma vez que a determinação da curva foi feita por secagem. A curva de calibração do papel filtro utilizada foi a determinada em estudos de Oliveira (2004) para o papel filtro Whatman 42 lote 920071, e é expressa por duas equações logarítmicas (Equações [14] e [15]), sendo o teor de umidade de $30 \%$ o critério limítrofe para o emprego de cada uma.

$$
\begin{aligned}
& S=10^{(7,91-3,8 \cdot \log (w))}, \text { para } w<30 \% \\
& S=10^{(5,75-2,34 \cdot \log (w))}, \text { para } w>30 \%
\end{aligned}
$$

As curvas de retenção do solo na forma de teor de umidade volumétrico em função da sucção para os três corpos de prova são exibidas nas Figura 64 a Figura 66.

Figura 64. Curva de retenção do solo: teor de umidade volumétrico em função da sucção

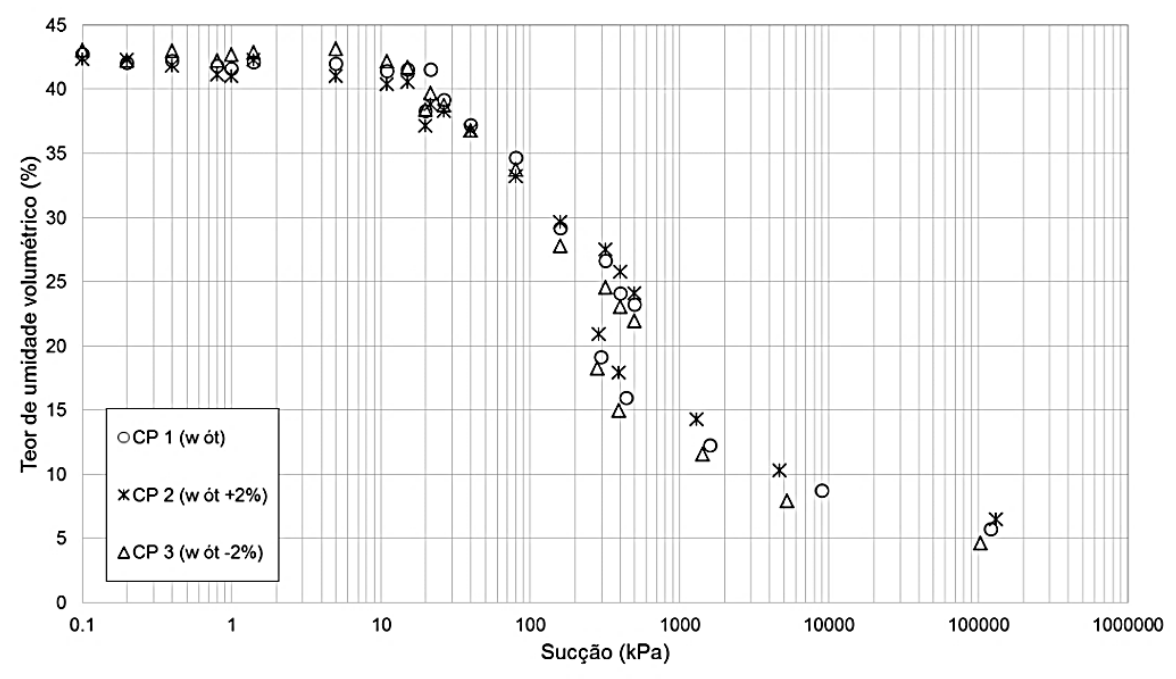


Figura 65. Curva de retenção do solo: teor de umidade gravimétrico em função da sucção

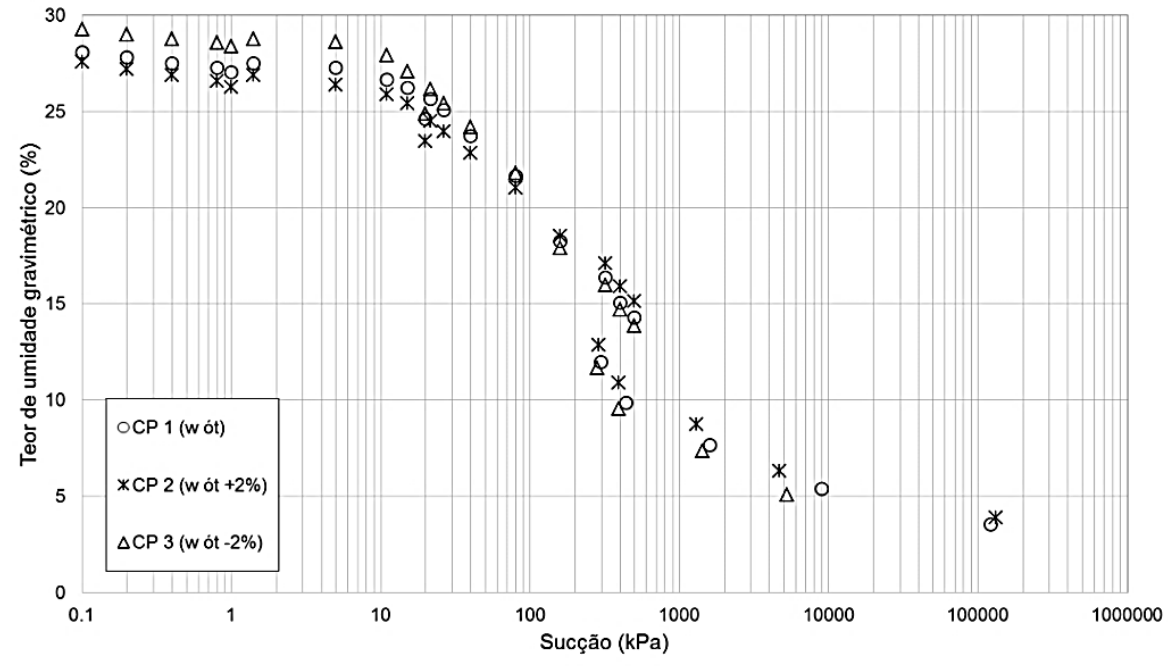

Figura 66. Curva de retenção do solo: grau de saturação em função da sucção

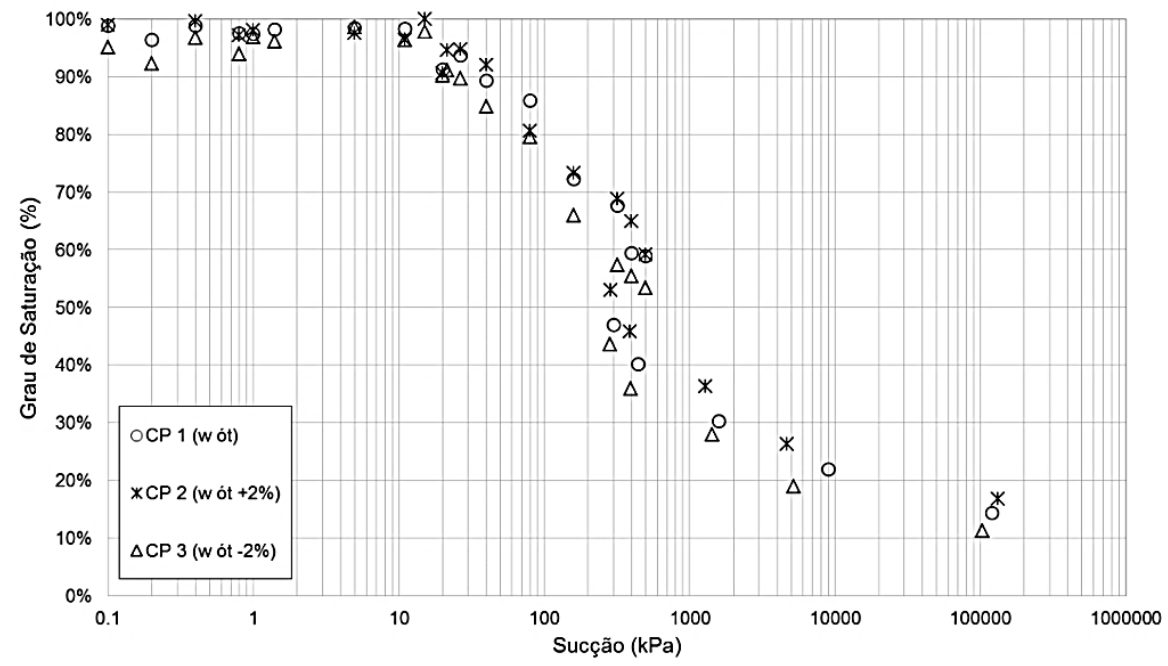

As curvas foram ajustadas ao modelo de van Genuchten (1980). O cálculo dos coeficientes $\alpha, n$ e $m$ se deu de forma a minimizar o erro calculado (Equações [18]), baseando-se no critério de aceitação do ajuste proposto por Gerscovich (2001), que preconiza que erros menores que 4 fornecem representações de boa qualidade dos dados experimentais.

$$
\varepsilon=\frac{1}{N} \cdot \sum_{i=1}^{N}\left(\theta_{i}-\theta_{i}^{\wedge}\right)^{2}
$$


Onde: $\varepsilon=$ erro;

$\theta_{i}=$ teor de umidade volumétrico previsto;

$\theta_{i}^{\wedge}=$ teor de umidade volumétrico medido; e

$N=$ número de dados experimentais.

Os valores dos parâmetros de ajuste podem ser visualizados na Tabela 10 e as curvas para cada corpo de prova encontram-se nas Figura 67 a Figura 69.

Tabela 10. Ajuste das curvas de retenção ao modelo de van Genuchten

\begin{tabular}{ccccccc}
\hline Corpo de prova & $\Delta \mathrm{w}$ & $\theta_{r}$ & $\theta_{s}$ & $\alpha$ & $\mathrm{n}$ & Erro \\
\hline CP 1 & 0 & 5,72 & 42,75 & 0.015345 & 1,4695 & 4,04 \\
\hline CP 2 & +2 & 6,45 & 42,32 & 0.019866 & 1,3941 & 4,28 \\
\hline CP 3 & -2 & 4,63 & 43,02 & 0.018199 & 1,4627 & 4,13 \\
\hline
\end{tabular}

Figura 67. Ajuste da curva de retenção: CP 1, w ótimo

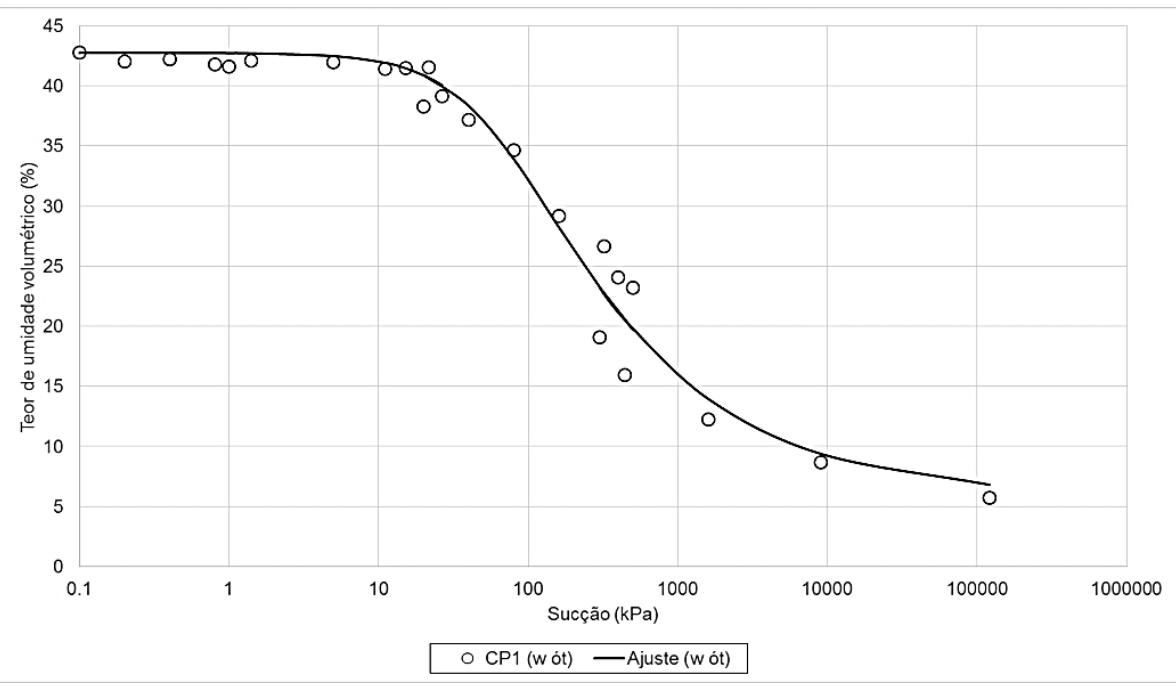


Figura 68. Ajuste da curva de retenção: CP 2, w ótimo $+2 \%$

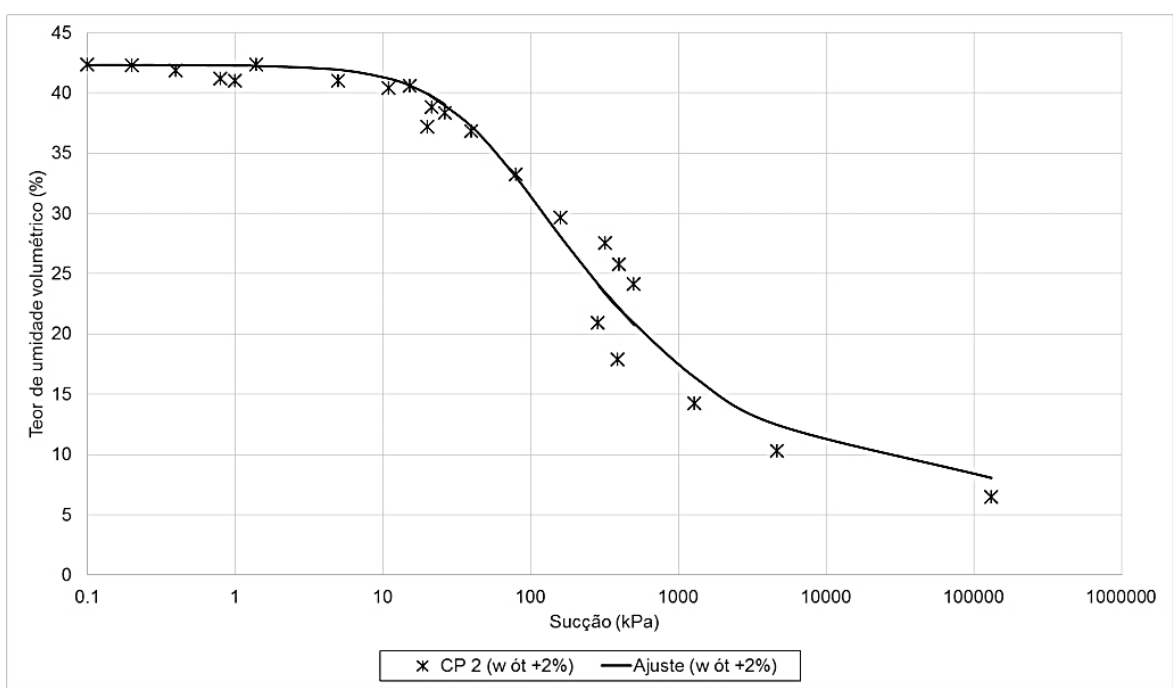

Figura 69. Ajuste da curva de retenção: CP 3, w ótimo - 2\%

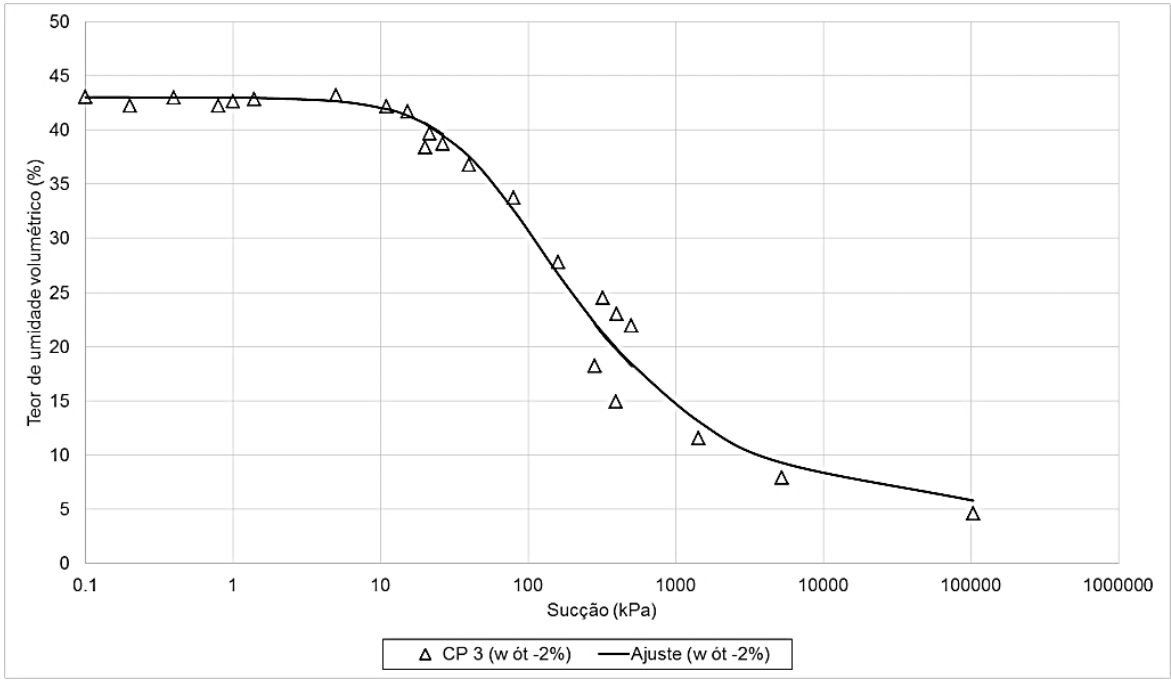

\section{Sublastro granular}

A análise granulométrica da amostra de BGS coletada no ato da construção do trecho experimental pode ser observada na Figura 70. Através desta, constata-se que a BGS utilizada como sublastro granular atende aos critérios de filtro definidos por Cedergren (1989) e objetivados no procedimento de dosagem da camada. 
Figura 70. Curva granulométrica do sublastro granular

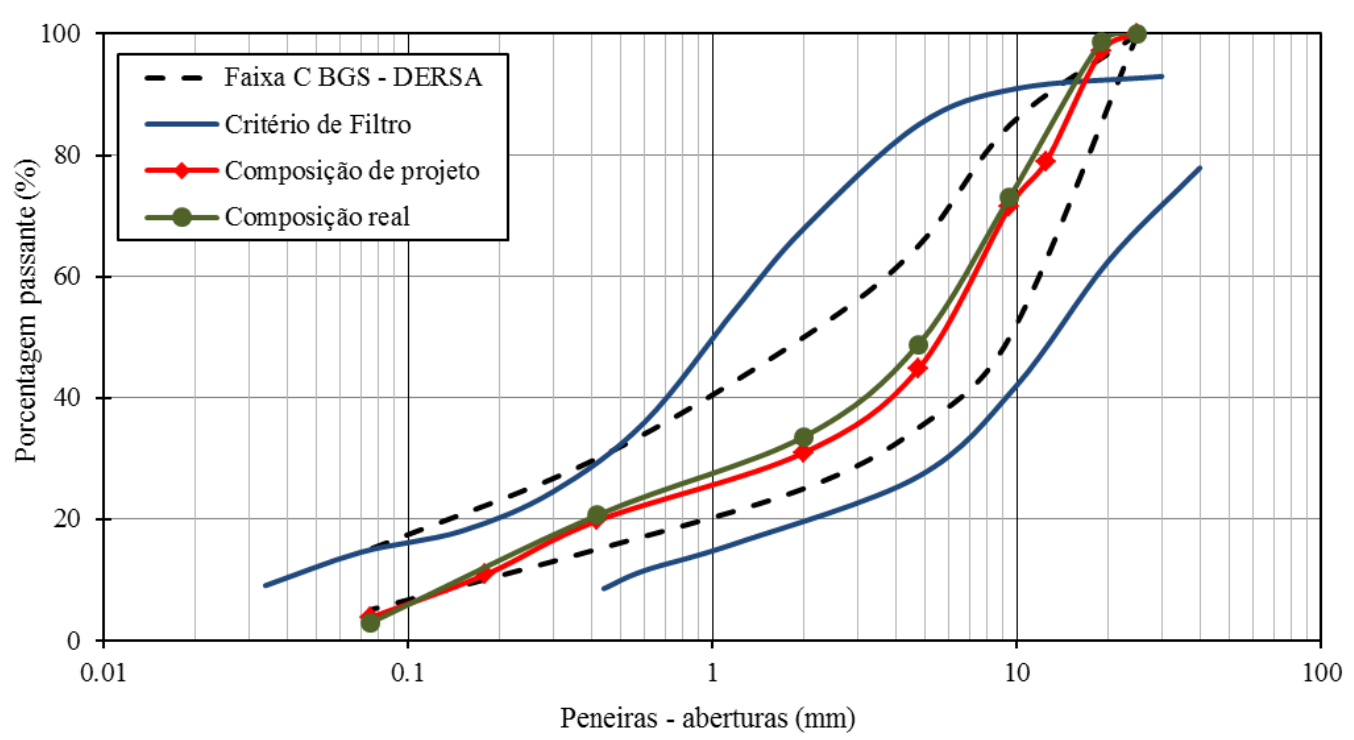

A curva de compactação característica da brita graduada simples realizada em laboratório à energia Proctor normal tem seu ponto máximo definido pelo par de valores: massa específica aparente seca máxima de $2,114 \mathrm{~g} / \mathrm{cm}^{3}$ e umidade ótima de $5,3 \%$. Teores de umidade de campo obtidos de amostras retiradas durante a execução do trecho experimental apontam que a camada de BGS foi compactada no ramo seco $(3,3 \%)$.

Os resultados de módulo de resiliência obtidos através do ensaio triaxial de carga repetida com influência da tensão de confinamento e desviadora podem ser visualizados na Figura 71. A energia de compactação foi a do Proctor normal e a umidade de moldagem obtida, a posteriori, foi de $4,7 \%$. Comparando os valores de módulo de resiliência para tensão de confinamento e desviadora de 0,1 $\mathrm{MPa}$, têm-se valores de $235 \mathrm{MPa}$ e $171 \mathrm{MPa}$, respectivamente. Nota-se que se trata de material com característica efetivamente granular, cujo módulo de resiliência é dependente da tensão de confinamento. 
Figura 71. Módulo de resiliência do sublastro granular
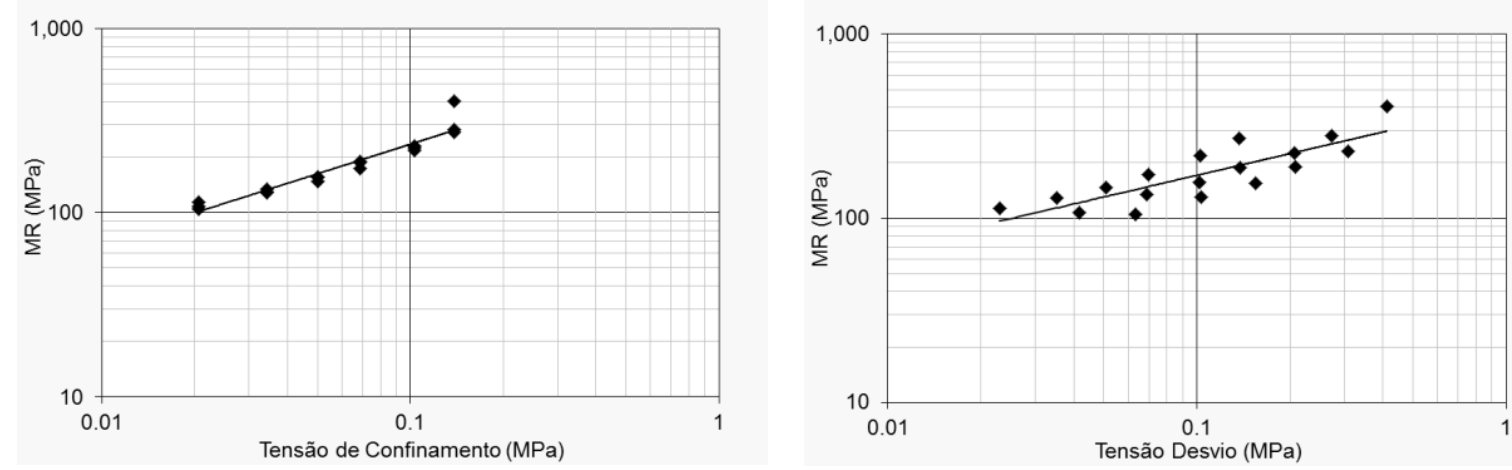

Lastro

Amostras trazidas de campo foram reduzidas, lavadas e analisadas quanto à sua distribuição granulométrica (Figura 72). A avaliação da forma dos agregados de acordo com a ASTM D4791 (2010) não atendeu ao limite recomendado, contendo porcentagem de partículas lamelares e alongadas superior a 5\% (Tabela 11). A perda por abrasão Los Angeles do material de lastro foi de $13 \%$, valor dentro da faixa de aceitação definida pela ABNT NBR 5564 (2014) e AREMA (2013).

Figura 72. Curva granulométrica do material de lastro

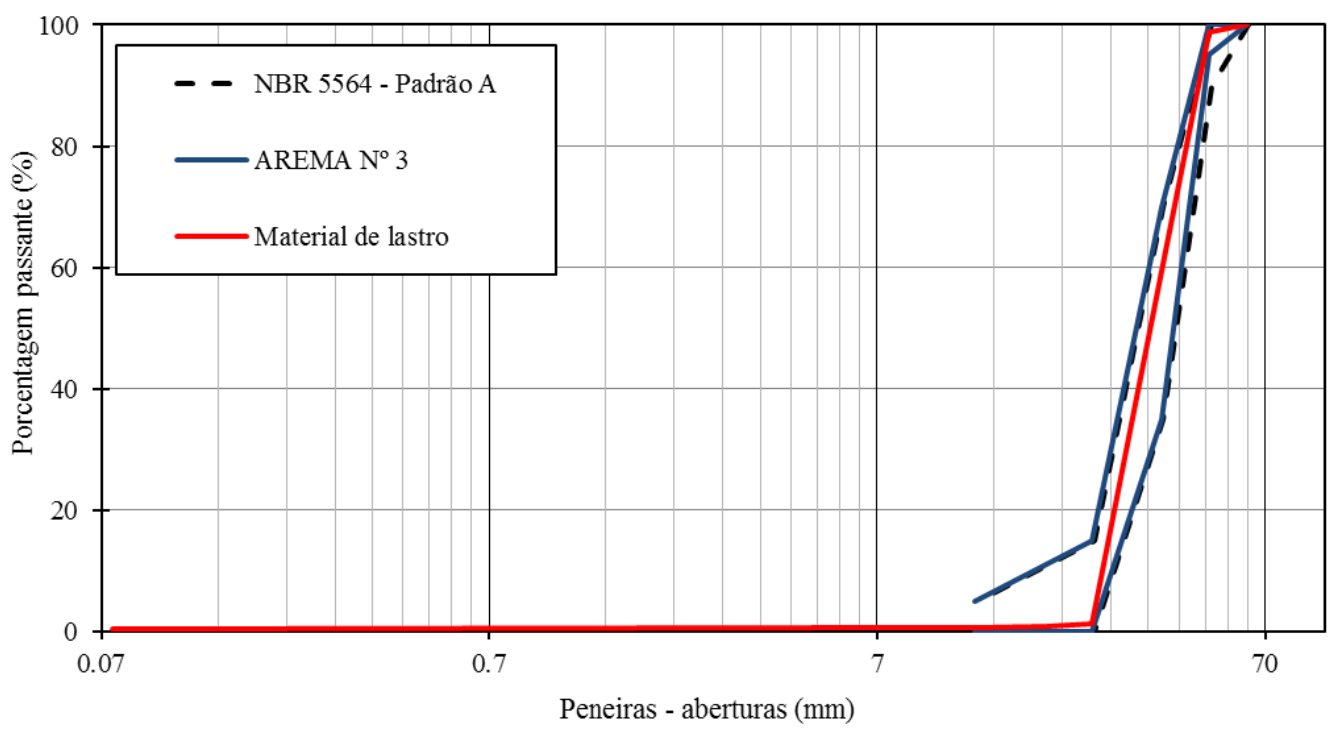


Tabela 11. Resultados dos ensaios de forma do material de lastro

\begin{tabular}{cc}
\hline $\begin{array}{c}\text { Grãos lamelares e } \\
\text { alongados (\%) }\end{array}$ & $\begin{array}{c}\text { Grãos nem lamelares e } \\
\text { nem alongados (\%) }\end{array}$ \\
\hline 9,4 & 90,6 \\
\hline
\end{tabular}

Sublastro betuminoso

As características da mistura asfáltica utilizada e a curva granulométrica dos agregados que a compõem podem ser vistas nas Tabela 12 e Figura 73, respectivamente.

Tabela 12. Caracterização física da mistura asfáltica

\begin{tabular}{ll}
\hline Propriedade & Sub. Betuminoso \\
\hline Ligante asfáltico & CAP 50/70 \\
\hline Teor de ligante $(\%)$ & 4,7 \\
\hline Massa específica teórica $\left(\mathrm{g} / \mathrm{cm}^{3}\right)$ & 2,484 \\
\hline Volume de vazios $(\%)$ & 10,3 \\
\hline
\end{tabular}

Figura 73. Curva granulométrica dos agregados (mistura asfáltica)

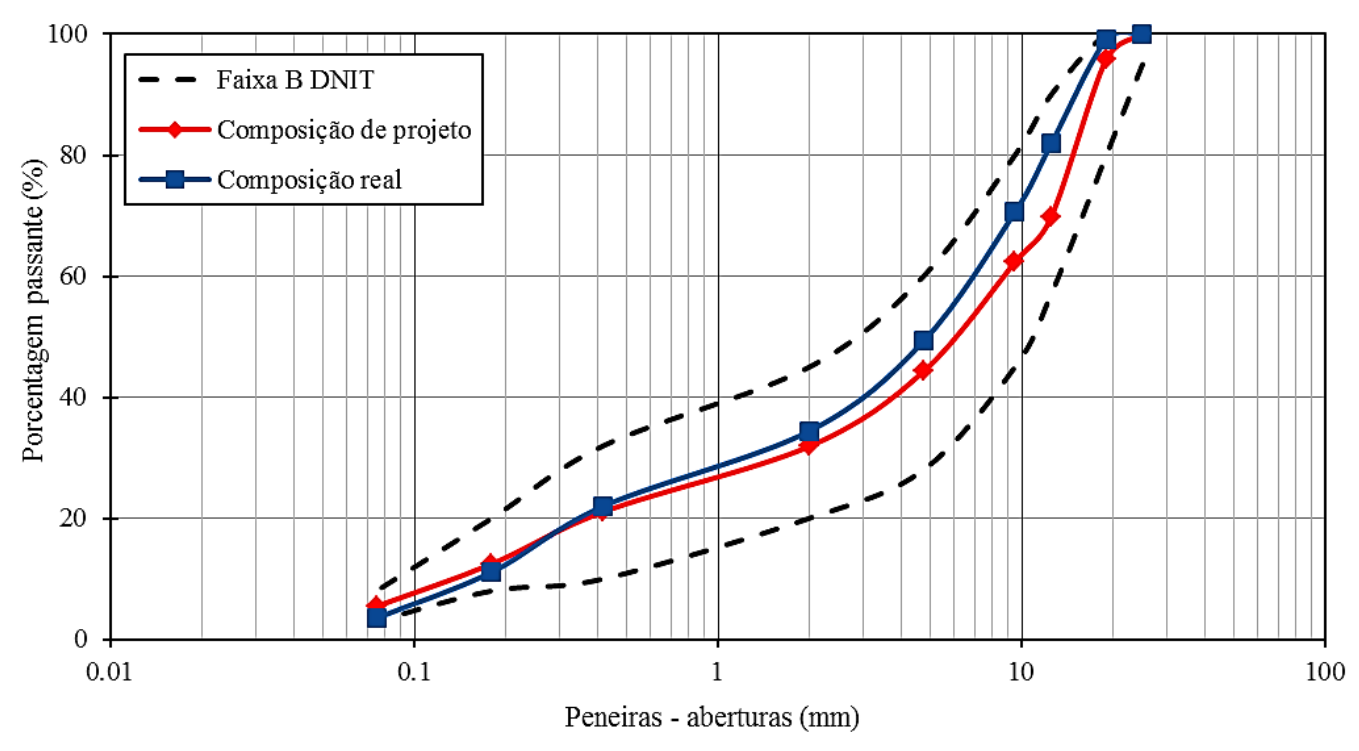

O teor de ligante e o volume de vazios do $C B \cup Q$ estão acima dos valores definidos pela dosagem Marshall de projeto. A mistura apresenta um acréscimo de 0,5\% de ligante asfáltico em relação ao teor de projeto, porém ainda em concordância com as sugestões de Bryson e Rose (2009). O volume de vazios, por sua vez, ficou bastante elevado, quando comparado com os valores recomendados (1 a $3 \%$ de vazios) para 
esse tipo de aplicação, sendo possivelmente fruto da compactação deficiente da camada em campo.

O ensaio triaxial com carga repetida, a $25^{\circ} \mathrm{C}$, realizado em corpos de prova compactados pela metodologia Marshall (com número de golpes alterado, para que fosse atingido o volume de vazios representativo da condição de campo, ou seja 10\%), resultou em um valor de MR médio de $4.000 \mathrm{MPa}$.

A relação encontrada entre a resistência a tração por compressão diametral obtida em corpos de prova condicionados (induzidos ao dano por umidade) e corpos de prova de um grupo controle foi de $68 \%$. A mistura asfáltica seria então tida como sensível ao dano por umidade induzida, mas em condição bastante aproximada do limite de 70\% recomendado pela norma ASTM D4867/D4867M - 09.

\section{Comentários}

Através da caracterização do solo que compõe a camada de subleito pode-se ter uma melhor compreensão do desempenho desta em campo. A reduzida propensão a fenômenos de expansão e contração, consequência da presença de determinados argilominerais, constituiu-se como uma característica favorável para o comportamento mecânico da via, uma vez que a variação no teor de umidade da camada não implicará em significativas alterações de volume e perda de capacidade de suporte do subleito. No entanto, a constatação de que a compactação da camada foi realizada a um elevado grau de saturação do material alerta para o fato de que a mesma já iniciou sua vida útil com reduzida resistência às deformações por cisalhamento, causada pela falta de contato efetivo entre as partículas finas de solo quando compactados no ramo úmido.

Uma análise comparativa dos valores de tensão de sucção oriundos dos sensores instalados nos trechos e as curvas de retenção por teor de umidade e/ou grau de saturação do solo confirma a premissa de que a camada de subleito encontra-se com teores de umidade variando de 17\% a 45\% (Figura 64 e Figura 65), aproximadamente. No entanto, a notar pelas curvas características, a faixa de medição dos sensores 
WATERMARK (0 a $200 \mathrm{kPa}$ ) não é capaz de fornecer sinais da variação no teor de umidade mais certeiros para condições secas do material (grau de saturação abaixo de 60\% - Figura 66). Dessa forma, os sensores que atingiram $200 \mathrm{kPa}$ em leituras de acompanhamento podem indicar que aquela região do subleito apresentava teores de umidade iguais ou inferiores ao teor "ótimo" de 18,5\%. Recomenda-se, portanto, que análises de dados oriundos de instrumentação de campo sejam sempre combinadas a uma caracterização mais aprofundada de cada material. Ademais, pode-se concluir, de maneira geral, que durante todo o período analisado a camada de subleito apresentou-se parcial a completamente saturada, a exceção dos pontos localizados em profundidade mais próxima ao eixo da via, nos quais não se pode aferir a magnitude das variações em termos de saturação.

O emprego de sublastro betuminoso, como verificado anteriormente, auxilia na redução das variações de amplitude das tensões de sucção das camadas granulares subjacentes. Porém, caso estas sejam compactadas em condições divergentes às ideais (à massa específica aparente seca máxima), a mistura asfáltica acaba por manter tais condições desfavoráveis inalteradas por mais tempo, tornando-se prejudicial ao pavimento como um todo. Deve-se, portanto, uma vez que se optar pela adoção de novas técnicas tais como esta, que se elaborem projetos adequados e sejam assegurados rigorosos controles de qualidade dos materiais e do processo construtivo. Para o caso específico dos trechos estudados, o elevado teor de umidade na camada de subleito pode vir a acelerar mecanismos de deterioração de deformação e trincamento por fadiga da mistura asfáltica em particular, que em contato direto com a água pode sofrer com a percolação desta através dos vazios.

Terrel e Al-Swailmi (1993), em estudo sobre a influência do volume de vazios na perda de resistência de misturas asfálticas, definiram como péssimo o intervalo de vazios da faixa que vai de $4 \%$ a $13 \%$. Valores abaixo de $4 \%$ indicam que a mistura possui propriedades impermeáveis e valores acima de 13\% constituem material de graduação aberta, com vazios interconectados e função drenante. A perda de relação da resistência à tração por compressão diametral verificada para o grupo de corpos de prova condicionados ao dano por umidade induzida confirma tal premissa e indicaria uma provável redução da capacidade de suporte da camada de sublastro 
betuminoso. No entanto, o ensaio adotado para aferição deste parâmetro também condiciona os corpos de prova termicamente, situação que não foi verificada de forma efetiva na camada, a partir de constatações feitas através dos dados de temperatura de campo. Sendo, portanto, demasiado conservador neste aspecto. Complementarmente, o limite de $70 \%$ recomendado pela norma ASTM D4867/D4867M - 09 é referente a misturas asfálticas empregadas em camadas de rolamento de pavimento rodoviário, nas quais a carga é aplicada diretamente na camada e a incidência de variações climáticas podem ser mais prejudiciais.

Quanto aos módulos de resiliência obtidos para as camadas de sublastro e subleito, pode-se afirmar que ambos os trechos experimentais atendem aos requisitos de rigidez mínimos para um bom comportamento mecânico da via (Subleito: MR de 68 MPa, BGS: 235 MPa e CBUQ: 4.000 MPa). Ebersöhn e Selig (1994) consideram faixas aceitáveis de MR para camada de sublastro valores entre $69 \mathrm{MPa}$ e $276 \mathrm{MPa}$, e entre $14 \mathrm{MPa}$ e $138 \mathrm{MPa}$ para camada de subleito. Di Mino et al. (2015) e Rose et al. (2011) definem como $40 \mathrm{MPa}$ e $200 \mathrm{MPa}$ os valores mínimos de capacidade de carga de camada de subleito e sublastro, respectivamente, para emprego da solução de sublastro betuminoso, igualmente atendidas nesse estudo, apesar dos autores não especificarem de maneira direta o procedimento para obtenção destes parâmetros. Atenta-se, porém, ao fato de que ambas as camadas de sublastro estão com espessuras efetivas menores que as projetadas e que os valores de módulo de resiliência obtidos em laboratório podem não representar diretamente as condições de suporte destas em campo. 


\section{CONCLUSÕES E COMENTÁRIOS FINAIS}

O presente estudo buscou avaliar a influência da inserção de uma camada de sublastro betuminoso na configuração estrutural de uma via permanente de carga brasileira, em termos de resposta mecânica e geométrica. As análises pautaram-se, de maneira geral, em parâmetros medidos "in situ" ao longo do acúmulo de solicitações e frente a variadas condições climáticas de duas seções experimentais instrumentadas: uma contendo sublastro de concreto betuminoso usinado a quente e outra contendo sublastro de brita graduada simples. Ambas construídas em um contexto de renovação de via, na região da Baixada Santista (São Paulo), e operada pela empresa MRS Logística.

Processos de reabilitação estrutural e de manutenção caracterizam-se como parcela mais dispendiosa do custo total com infraestrutura ferroviária, buscando ser evitados. Dentre as problemáticas atreladas à necessidade de intervenções deste tipo, tem-se a limitação de tempo de paralisação de operação da linha e o desprendimento de equipamentos, pessoal e materiais em grandes quantidades, quando da substituição parcial ou total de componentes. Uma considerável parcela da malha ferroviária brasileira estende-se por regiões de difícil acesso por rodovias pavimentadas, sendo necessário que qualquer procedimento relacionado a manutenções seja capaz de atingir os pontos a serem renovados fazendo uso da própria via férrea, o que, a princípio, sinalizaria um ponto crítico para o emprego de sublastro betuminoso como técnica de renovação do pavimento. Tais constatações, porém, confirmaram-se incongruentes no ato desta pesquisa. Apesar das adversidades atreladas à localização do ponto estudado e à ausência de experiência prévia dos envolvidos na utilização de misturas asfálticas em intervenções de cunho ferroviário (visto que este se constituía de trecho pioneiro no país), conclui-se que a técnica é viável e pode ser adotada no contexto nacional com bons resultados.

Ressalta-se que, por impossibilidades técnicas, construtivas e financeiras, a comparação direta entre ambas soluções não se fez possível e que, portanto, o objetivo principal do trabalho em questão não foi completamente atingido. As espessuras distintas de camadas somadas às características bastante divergentes de 
ambos materiais empregados como camada de sublastro inviabilizaram uma análise dos dois perfis estruturais à luz somente de medidas "in situ" do comportamento mecânico e geométrico da via, sendo necessária uma investigação aprofundada em termos de simulações numéricas através de modelos computacionais. Assim, o impacto positivo gerado pela inserção de uma camada mais rígida quando comparada a estrutura granular convencional adotada e a observada tendência da seção betuminosa em sofrer menores deflexões verticais não são base suficiente para escolha de uma solução em detrimento da outra, considerando as configurações estudadas.

No entanto, alguns pontos devem ser enaltecidos como frutos significativos desta pesquisa, estando o primeiro relacionado à necessidade de se desenvolver de forma mais efetiva a aferição de dados em campo como subsídio para compreensão do comportamento estrutural e geométrico de vias permanentes. A pura análise de valores registrados em sensores inseridos na via ou por intermédio de dispositivos considerando somente o contexto singular qual se insere a medição, por vezes não retrata o comportamento do pavimento de maneira global e pode mascarar efeitos danosos ou superestimar situações atípicas na região. Somado a isto, faz-se imprescindível ressaltar a importância de se compreender corretamente o funcionamento e a sensibilidade de equipamentos de avaliação da condição "in situ" de quaisquer que sejam os perfis estruturais da via e a correlação com tais medidas a características intrínsecas de cada material, tais como o observado para a relação entre os valores de tensão de sucção do subleito obtidos em campo e o comportamento do solo frente à variação do seu teor de umidade, determinado em laboratório.

Acredita-se que o período estudado não foi suficientemente abrangente em relação a estes aspectos e que a condição de solicitações da via permanente contendo tanto sublastro betuminoso como sublastro granular ainda não ultrapassou o período de densificação da camada de lastro. Isto porque ainda se tem um reduzido acúmulo de MTBT na linha, o que indica que hipóteses que venham a ser assumidas para explicar o desempenho estrutural e geométrico da via até o presente momento são demasiadamente prematuras. Igualmente deficiente constitui-se a análise da via por 
uma duração que seja inferior a um ano, em vistas das alterações nas variáveis climáticas atuantes no pavimento a cada estação.

No que concerne a camada de sublastro betuminoso propriamente dita, pode-se inferir que, assim como preconizado por Cardona et al. (2016), este não deve ser avaliado quanto a parâmetros de caracterização mecânica adotados comumente para o meio rodoviário. Os dados oriundos dos sensores de temperatura, de tensão de sucção e de tensão de compressão atuantes no pavimento estudado mostram que a camada asfáltica se encontra em uma condição particular quanto às solicitações. Como exemplo, tem-se que, durante o período analisado, a variação térmica atinge valores bastante reduzidos ao longo da camada, quando comparados a gradientes térmicos registrados em rodovias brasileiras. Da mesma forma, não se pode inferir que esta se encontra completamente resguardada de intempéries devido a sua localização abaixo da camada de lastro, como observado através das tensões de suç̧ão medidas na camada de subleito e que registraram contato direto e constante da mistura asfáltica com umidade.

Baseando-se nisso, recomenda-se que detalhes de projeto, por vezes negligenciados, sejam rigorosamente controlados na execução de vias permanentes, sejam elas constituídas por camadas de sublastro betuminoso ou granular. A adoção de inclinações nas camadas da subestrutura que sejam capazes de direcionar a água proveniente de precipitações para dispositivos efetivos de drenagem constitui-se essencial para o desempenho satisfatório do pavimento como conjunto. Igualmente importante faz-se o procedimento de sondagem prévia e controle tecnológico quando da construção de novas linhas ou renovações de regiões problemáticas de vias existentes.

Adicionalmente, conclui-se que existe uma relação bidirecional entre aspectos geométricos e a resposta mecânica do pavimento ferroviário, verificada de maneira simplificada neste estudo. De forma particular, esta relação fica evidente quando analisado o comportamento das seções antes e após a intervenção mecanizada da socaria, mas que carece de estudos mais aprofundados para que sejam elaboradas correlações adequadas para cada tipo de via férrea. 
Por fim, espera-se que os esforços desprendidos no desenrolar desta pesquisa sejam de valia para o desenvolvimento de demais estudos na área de engenharia de transportes, buscando elucidar problemáticas referentes ao contexto ferroviário nacional e propor soluções técnica, econômica e ambientalmente viáveis. 
ABNT. NBR 27. Agregados - Redução da amostra de campo para ensaios de laboratório. Associação Brasileira de Normas Técnicas. Rio de Janeiro. 2001.

ABNT. NBR 248. Agregados - Determinação da composição granulométrica. Associação Brasileira de Normas Técnicas. Rio de Janeiro. 2003.

ABNT. NBR 6457. Amostras de solo - Preparação para ensaios de compactação e ensaios de caracterização. Associação Brasileira de Normas Técnicas. Rio de Janeiro. 2016.

ABNT. NBR 6459. Solo - Determinação do limite de liquidez. Associação Brasileira de Normas Técnicas. Rio de Janeiro. 2016.

ABNT. NBR 6476. Materiais asfálticos - Determinação da penetração. Associação Brasileira de Normas Técnicas. Rio de Janeiro. 2007.

ABNT. NBR 7180. Solo - Determinação do limite de plasticidade. Associação Brasileira de Normas Técnicas. Rio de Janeiro. 2016.

ABNT. NBR 7181. Solo - Análise granulométrica. Associação Brasileira de Normas Técnicas. Rio de Janeiro. 2016.

ABNT. NBR 7182. Solo - Ensaio de Compactação. Associação Brasileira de Normas Técnicas. Rio de Janeiro. 2016.

ABNT. NBR 15619. Misturas asfálticas - Determinação da densidade máxima teórica e da massa específica máxima teórica em amostras não compactadas. Rio de Janeiro. 2016. 
ABNT. NBR 15785. Misturas asfálticas a quente - Utilização da aparelhagem Marshall para preparação dos corpos-de-prova com diferentes dimensões e aplicações. Rio de Janeiro. 2010.

ALBALAT, S. A.; DOMINGO, L. M.; SANCHIS, I. V.; HERRÁZ, J. I. R.; SEGARRA, A. V. Crumb rubber modified bitumen for sub-ballast layer. 9th World Congress on Railway Research. 9 p. França, 2011.

ASTM. C535. Standard Test Method for Resistance to Degradation of Large-Size Coarse Aggregate by Abrasion and Impact in the Los Angeles Machine. American Society for Testing and Materials. [S.I.]. 2012.

ASTM. D1188 - 07. Standard Test Method for Bulk Specific Gravity and Density of Compacted Bituminous Mixtures Using Coated Samples. American Society for Testing and Materials. [S.I.]. 2015.

ASTM. D4791 - Standard Test Method for Flat Particles, Elongated Particles, or Flat and Elongated Particles in Coarse Aggregate. American Society for Testing and Materials. [S.I.]. 2010.

ASTM. D4867/D4867M - 09. Standard Test Method for Effect of Moisture on Asphalt Concrete Paving Mixtures. American Society for Testing and Materials. [S.I.]. 2014.

ASTM. D5298-03. Standard Test Method for Measurement of Soil Potential (Suction) Using Filter Paper. American Society for Testing and Materials. [S.I.]. 2008.

ASTM. D6951/D6951M-09. Standard Test Method for Use of the Dynamic Cone Penetrometer in Shallow Pavement Applications. American Society for Testing and Materials. [S.I.]. 2015.

ASTM. E2583-07. Standard Test Method for Measuring Deflections with a Light Weight Deflectometer (LWD). American Society for Testing and Materials. [S.I.]. 2015. 
BALBO, J. T. Pavimentação Asfáltica: Materiais, Projeto e Restauração. São Paulo, BR: Oficina de Textos, 2007.

BARRA, B. S. Avaliação da ação da água no módulo complexo e na fadiga de misturas asfálticas densas. Tese de doutorado, Universidade Federal de Santa Catarina. Florianópolis, 363 p. 2009.

BERAWI, A. R. B.; DELGADO, R.; CALÇADA, R.; VALE, C. Evaluating track geometrical quality through different methodologies. International Journal of Technology. [S.I.], vol. 1, n. 1, p. 38-47. 2010.

BERNUCCI, L. B.; MOTTA, L. M. G.; CERATTI, J. A. P.; SOARES, J. B. Pavimentação Asfáltica: Formação Básica para Engenheiros. Rio de Janeiro, BR: Petrobras: ABEDA, 2008.

BING, A. J.; GROSS, A. Development of Railroad Track Degradation Models. Transportation Research Record, [S.I.], vol. 939, p. 27-31. 1983.

BONDER, B. H. Curvas de retenção de água de um solo coluvionar de Campinas obtidas mediante técnicas de laboratório e de campo. Dissertação de mestrado, Universidade Estadual de Campinas. Campinas, 152 p. 2008.

BRYSON, L. S.; ROSE, J. G. Pressure measurements and structural performance of hot mixed asphalt railway trackbeds. 8th International Conference. Urbana, $10 \mathrm{p}$. 2009.

CAMACHO, J. Estudos sobre o dimensionamento de pavimentos flexíveis para um subleito colapsível. Dissertação de mestrado, Universidade de São Paulo. São Paulo, 71 p. 1995.

CAMACHO, J. Peculiaridades de distribuição de umidades em bases de pavimento de solo arenoso fino laterítico. Tese de doutorado, Universidade de São Paulo. São Paulo, 180 p. 2002. 
CARDONA, D. R.; DI BENEDETTO, H.; SAUZEAT, C.; CALON, N.; SAUSSINE, G. Use of bituminous mixture layer in high-speed line trackbeds. Construction and Building Materials 125. p. 398-407. 2016.

CARDOSO, R.; FERNANDES, V.; FERREIRA, T. M.; TEIXEIRA, P. F. Settlement prediction of high speed railway embankments considering the accumulation of wetting and drying cycles. Unsaturated Soils: Research and Applications. Springer Berlin Heidelberg, p. 291-298. 2012.

COSTA, R. C. Proposição de dispositivo de medidas "in situ" para avaliação do comportamento mecânico de lastro ferroviário: Estudo de caso na Estrada de Ferro Carajás. Dissertação de mestrado, Universidade de São Paulo. São Paulo, 176 p. 2016.

DI MINO, G.; Di LIBERTO, M.; MAGGIORE, C.; NOTO, S. A dynamic model of ballasted rail track with bituminous sub-ballast layer. Procedia-Social and Behavioral Sciences, vol. 53, p. 366-378. 2012.

DI MINO, G.; DI LIBERTO, M.; NOTO, S.; SOTO, F. M. The resistance to fatigue of dry asphalt rubber concrete for sub-ballast layer. 15th International Conference of Railway Engineering. Espanha, 2015.

DNER. DNER-ME 083/98. Agregados - análise granulométrica. Departamento Nacional de Estradas e Rodagens. [S.I.], p. 01/05. 1998.

DNER. DNER-ME 228/94. Solos - Compactação em equipamento miniatura. Departamento Nacional de Estradas e Rodagens. [S.I.], p. 01/14. 1994.

DNER. DNER-ME 256/94. Solos compactados em equipamento miniatura Determinação da perda de massa por imersão. Departamento Nacional de Estradas e Rodagens. [S.I.], p. 01/06. 1994. 
DNER. DNER-ME 258/94. Solos compactados em equipamento miniatura - MiniMCV. Departamento Nacional de Estradas e Rodagens. [S.I.], p. 01/16. 1994.

DNER. DNER-CLA 259/96. Classificação de solos tropicais para finalidades rodoviárias utilizando corpos-de-prova compactados em equipamento miniatura. Departamento Nacional de Estradas e Rodagens. [S.I.], p. 01/06. 1996.

DERSA. DERSA ET-DE-P00/008. Sub-base ou base de brita graduada. Desenvolvimento Rodoviário S.A. São Paulo. 2005.

DNIT. DNIT 031/2004. Pavimentos flexíveis - Concreto asfáltico - Especificações de serviço. Departamento Nacional de Infraestrutura de Transportes. Rio de Janeiro. 2004.

DNIT. DNIT 134/2010. Pavimentos flexíveis - Solos - Determinação do módulo de resiliência - Método de ensaio. Departamento Nacional de Infraestrutura de Transportes. Rio de Janeiro. 2010.

DNIT. DNIT 134/2010. Pavimentação asfáltica - Misturas asfálticas Determinação do módulo de resiliência - Método de ensaio. Departamento Nacional de Infraestrutura de Transportes. Rio de Janeiro. 2010.

DNIT. DNIT ISF 207: Estudos Geotécnicos. Departamento Nacional de Infraestrutura de Transportes. Rio de Janeiro.

EBERSÖHN, W.; SELIG, E.T. Track modulus measurements on a Heavy Haul line. Transportation Research Record. [S.I.], vol. 1470, p. 78-83. 1994.

ESVELD, C. Modern Railway Track. $2^{\text {nd }}$. ed. [S.I.]: Delft University of Technology, 2001. 
FERREIRA, T. M.; TEIXEIRA, P. F.; CARDOSO, R. Impact of bituminous subballast on railroad track deformation considering atmospheric actions. Journal of Geotechnical and Geoenvironmental Engineering, p. 288-292. 2011.

FORTES, R. M.; MERIGHI, J. V.; ZUPPOLINI NETO, A. Método das Pastilhas para identificação expedita de solos tropicais. $2^{\circ}$ Congresso Rodoviário Português. Lisboa, 10 p. 2002.

FORTUNATO, E. M. C. Renovação de plataformas ferroviárias. Estudos relativos à capacidade de carga. Tese de doutorado, Universidade do Porto. Porto, $577 \mathrm{p}$. 2005.

FREDLUND, D. G.; RAHARDJO, H. Soil mechanics for unsaturated soils. New York: J. Wiley, 1993.

GERSCOVICH, D. M. S. Equações para modelagem da curva característica aplicadas a solos brasileiros. 4ํㅗpósio Brasileiro de Solos não Saturados, NSTA, v. 1, p. 76-92, 2001.

HAY, W. W. Railroad Engineering. [S.I.]: John Wiley \& Sons, 1982.

HUANG, Y. H.; ROSE, J. G.; KHOURY, C. J. Thickness design for hot-mix asphalt railroad trackbeds. Annual Journal AAPT, Miscellaneous. [S.I.], vol. 56, n. 87, p. 427453. 1987.

IBGE. Logística dos Transportes no Brasil. 2014. http://www.brasil.gov.br/infraestrutura/2014/11/ibge-mapeia-a-infraestrutura-dostransportes-no-brasil, acesso em 12 de março de 2017.

INDRARATNA, B.; SALIM, W.; RUJIKIATKAMJORN, C. Advanced rail geotechnology-ballasted. London, UK: Taylor \& Francis Group, 2011.

IWATA, S.; TABUCHI, T.; WARKENTIN, B. P. Soil-water interactions: mechanisms and applications. 2 ed. New York: Dekker, 1995. 
KIM, Y. R. Modeling of asphalt concrete. $1^{\text {st }}$ edition [S. I.]: McGraw-Hill Professional, 2009.

LI, D.; LOPRESTI, J.; DAVIS, D. Application and performance of hot-mix asphalt trackbed over soft subgrade. Railway Track \& Structures, vol. 98, n. 1, p. 13-15. 2002.

MARINHO, F. A. M. Medição de sucção em solos. Simpósio Brasileiro de Solos Não Saturados. Vol. 2, p. 373-397. Rio de Janeiro, 1997.

MOREIRA, R. A. S. Modelação e análise de tratamentos viscoelásticos multicamada para controlo passivo de vibrações. Tese de doutorado, Universidade do Porto. Porto, 494 p. 2004.

MOTTA, L. M. G.; ARAGÃO, F. T. S.; MEDINA, J. Concreto asfáltico para uso em ferrovia - atualização do conhecimento e exemplo de modelagem numérica. $21^{\circ}$ Encontro de Asfalto do Instituto Brasileiro de Petróleo, Gás e Biocombustíveis. Rio de Janeiro, 2014. $12 \mathrm{p}$.

MRS Logística S.A. https://www.mrs.com.br/, acesso em 13 de fevereiro de 2018.

NOGAMI, J. S.; VILLIBOR, D. F. Identificação Expedita dos Grupos de Classificação MCT para Solos Tropicais. $10^{\circ}$ COBRAMSEFABMS, Vol. 4, p. 12931300. Foz do Iguaçu. 1994.

OLIVEIRA, O. M. Estudo sobre a resistência ao cisalhamento de um solo residual compactado não saturado. Tese de doutorado, Universidade de São Paulo. São Paulo, 330 p. 2004.

OLIVEIRA FILHO, J. J. P. Estudo de viabilidade técnica da utilização de coberturas monolíticos em aterros sanitários no Estado de São Paulo. Dissertação de mestrado, Universidade de São Paulo. 204 p. 2004. 
OTTO, G. G. Misturas asfálticas mornas - verificação da fadiga e do módulo complexo. Dissertação de mestrado, Universidade Federal de Santa Catarina. Florianópolis, 179 p. 2009.

PROFILLIDIS, V. A. Railway Management and Engineering. THIRD. ed. [S.I.]: Ashgate Publishing Limited, 2006.

RAHIM, A.; GEORGE, K. P. Falling weight deflectometer for estimating subgrade elastic moduli. Journal of Transportation Engineering, [S.I.], vol. 129, n. 1, p. 100 107. 2003.

RANGEL, G. W. A.; ARAGÃO, F. T. S.; MOTTA, L. M. G. Modelagem computacional do pavimento ferroviário usando concreto asfáltico como alternativa para a construção da camada de sublastro. 44ํำ Reunião Anual de Pavimentação. Foz do Iguaçu, 2015. $15 \mathrm{p}$.

REVISTA FERROVIÁRIA. Minério de ferro é a principal carga dos vagões pelo país. Valor Econômico. 2013.

ROSE, J. G. Design, Evaluation, and Performance of Asphalt Trackbeds - U.S. Experiences. International Seminar on Optimization of railway design using bituminous sub-ballast. Lisboa, 2011.

ROSE, J. G.; BRYSON, L. S. Hot mix asphalt railway trackbeds: trackbed materials, performance evaluations, and significant implications. International Conference on Perpetual Pavements. Columbus, 19 p. 2009.

ROSE, J. G.; LI, D.; WALKER, L. A. Tests and evaluations of in-service asphalt trackbeds. American Railway Engineering and Maintenance-of-Way Association Annual Conference \& Exposition. Washington, DC, p. 29. 2002. 
ROSE, J. G.; SOULEYRETTE, R. R. Asphalt Railway Trackbeds: Recent designs, applications and performances. 2015 AREMA Annual Conference. Minneapolis, 2015.

ROSE, J. G.; TEIXEIRA, P. F.; VEIT, P. International design practices, applications, and performances of asphalt/bituminous railway trackbeds. GEORAIL 2011 - International Symposium. Paris, 23 p. 2011.

ROSE, J. G.; UZARSKI, D. R. Performance-based trackbed structural design and analysis utilizing KENTRACK. GEORAIL 2011 - International Symposium. Paris, 22 p. 2011.

SELIG, E. T.; WATERS, J. M. Track Geotechnology and Substructure Management. New York: Thomas Telford Services LTD., 1994.

SILVA, L. F. M. D. Fundamentos teóricos-experimentais da mecânica dos pavimentos ferroviários e esboço de um sistema de gerência aplicado à manutenção da via permanente. Tese de Doutorado, COPPE/UFRJ. Rio de Janeiro, 333 p. 2002.

SILVA, E. T. F. Análise da evolução dos defeitos de bitola na via permanente da MRS para planejamento de intervenções preditivas de manutenção. Curso de Especialização em Transporte Ferroviário de Carga, Instituto Militar de Engenharia. Rio de Janeiro, 73 p. 2006.

SOTO, M. A. A. Comparação entre métodos de imposição e de controle de sucção em ensaios com solos não saturados. Tese de doutorado, Universidade de São Paulo. São Carlos, 233 p. 2004.

TEIXEIRA, P. F. Interest of using bituminous sub-ballast in railway infrastructures. International Seminar on Optimization of railway design using bituminous sub-ballast. Lisboa, 2011. 
TEIXEIRA, P. F.; PITA, A. L.; CASAS, C.; BACHILLER, A.; ROBUSTÉ, F. Improvements in high-speed ballasted track design: Benefits of bituminous subballast layers. Transportation Research Record: Journal of the Transportation Research Board, n. 1943, p. 43-49. 2006.

TEIXEIRA, P. F.; PITA, A. L.; FERREIRA, P. A. New possibilities to reduce track costs on high-speed lines using a bituminous sub-ballast layer. International Journal of Pavement Engineering. [S.I.], vol. 11, n. 4, p. 301-307. 2010.

TERREL, R. L.; AL-SWAILMI, S. The role of pessimum voids concept in understanding moisture damage to asphalt concrete mixtures. Transportation Research Record, [S.I.], n. 1386, p. 31-37.1993.

TOLL, D. G.; ASQUITH, J. D.; FRASER, A.; HASSAN, A. A.; LIU, G.; LOURENÇO, S. D. N.; MENDES, J.; NOGUCHI, T.; OSINSKI, P.; STIRLING, R. Tensiometer techniques for determining soil water retention curves. 6th Asia Pacific Conference on Unsaturated Soils. China, p. 15. 2015.

VASSOLER, G.; CHONG, W.; SPECHT, L. P. Comportamento mecânico de pavimentos flexíveis submetidos a gradientes térmicos. Acta Scientiarum Technology. [S.I.], vol. 33, n. 3, p. 265-271. 2011.

ZERBST, U.; LUNDÉN, R.; EDEL, K. O.; SMITH, R. A. Introduction to the damage tolerance behaviour of railway rails - a review. Engineering fracture mechanics. [S.I.], vol. 76, n. 17, p. 2563-2601. 2009. 


\section{ANEXO A - Dados pluviométricos.}

Precipitação: pluviômetro automático Vila Parise (CEMADEN - Código 351350403A) localizado a $5 \mathrm{~km}$ de distância das seções de via permanente analisadas.

$$
\text { Julho }-2017
$$

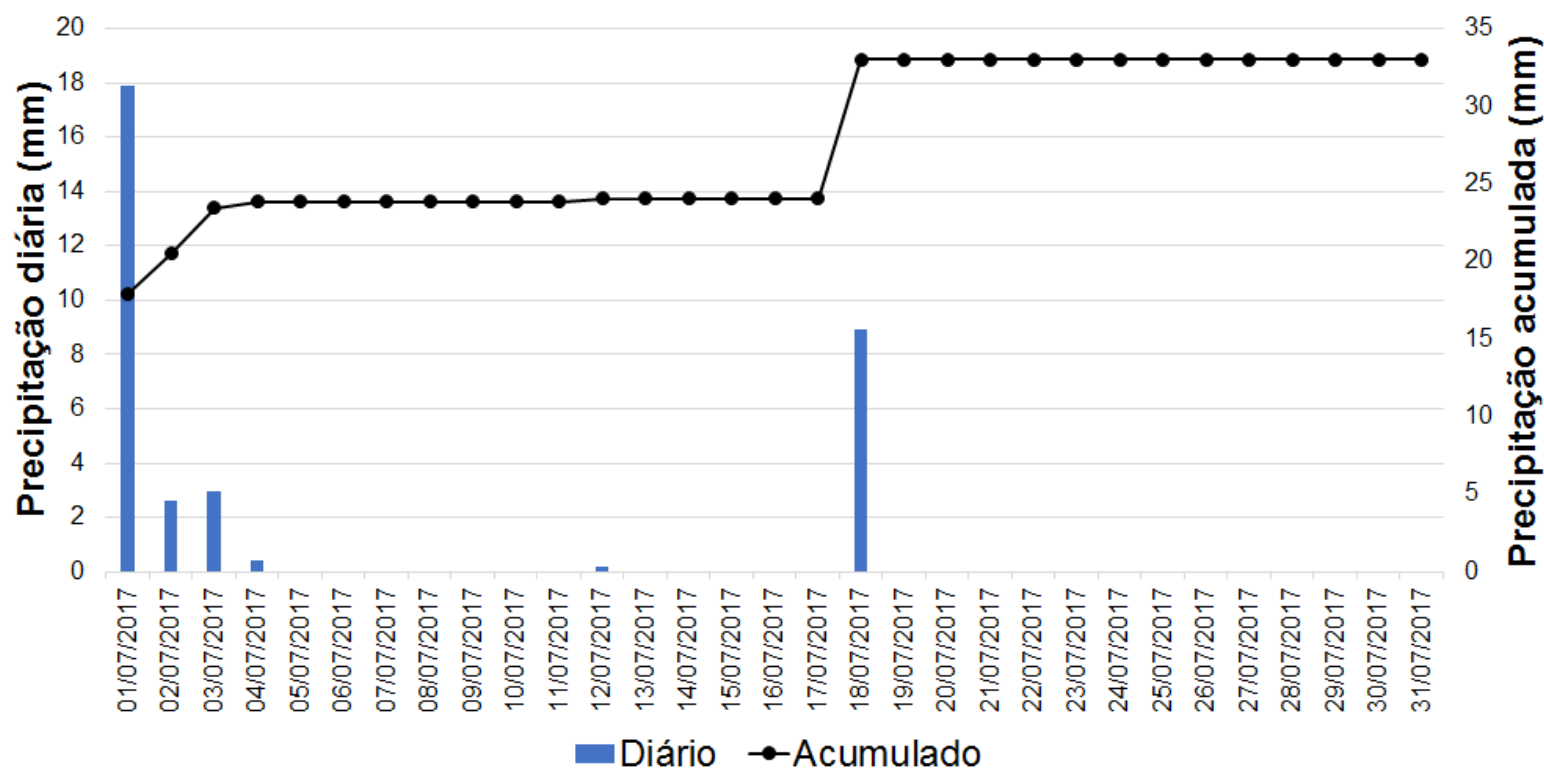

Agosto - 2017

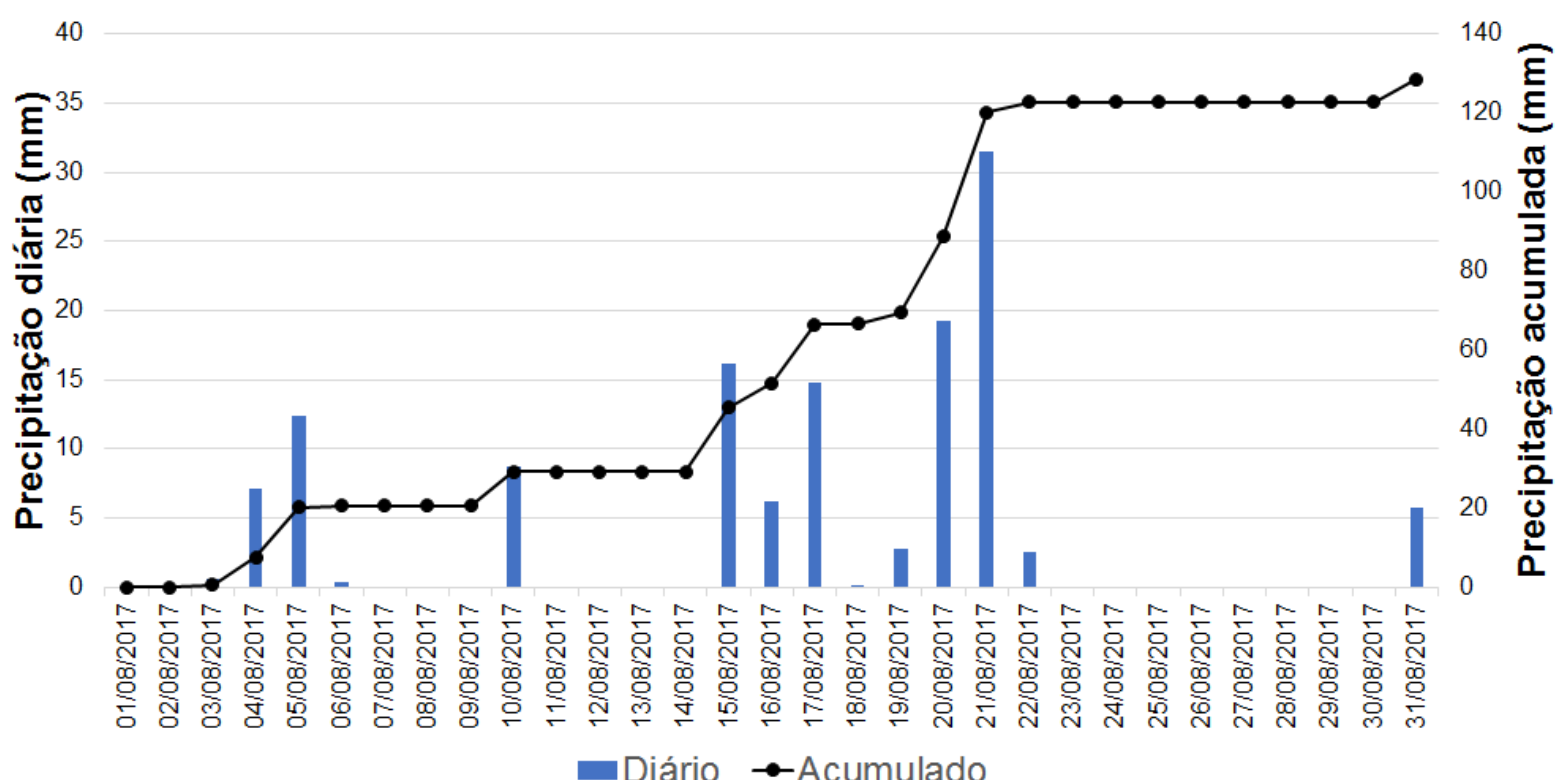


Setembro - 2017

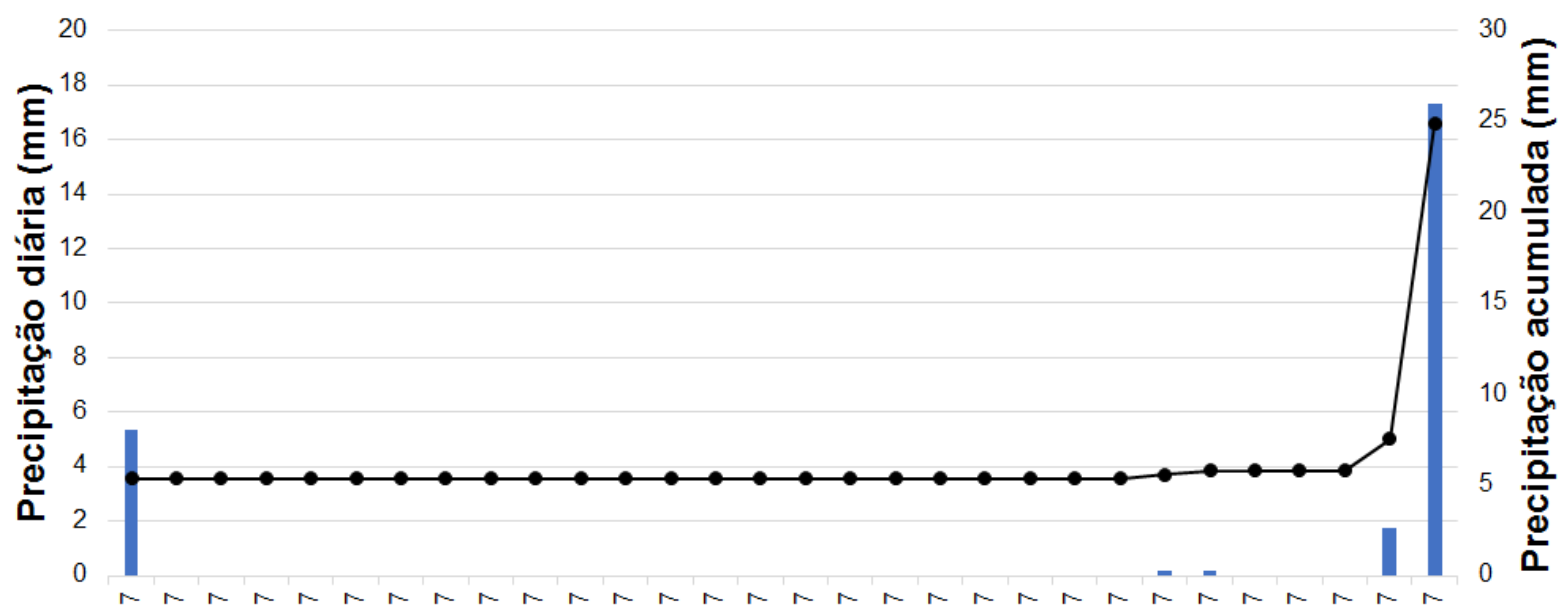

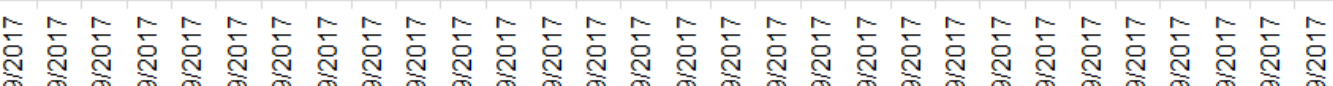

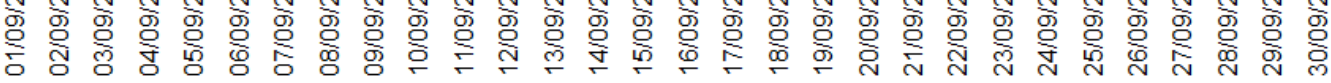

Diário -A-Acumulado

Outubro - 2017

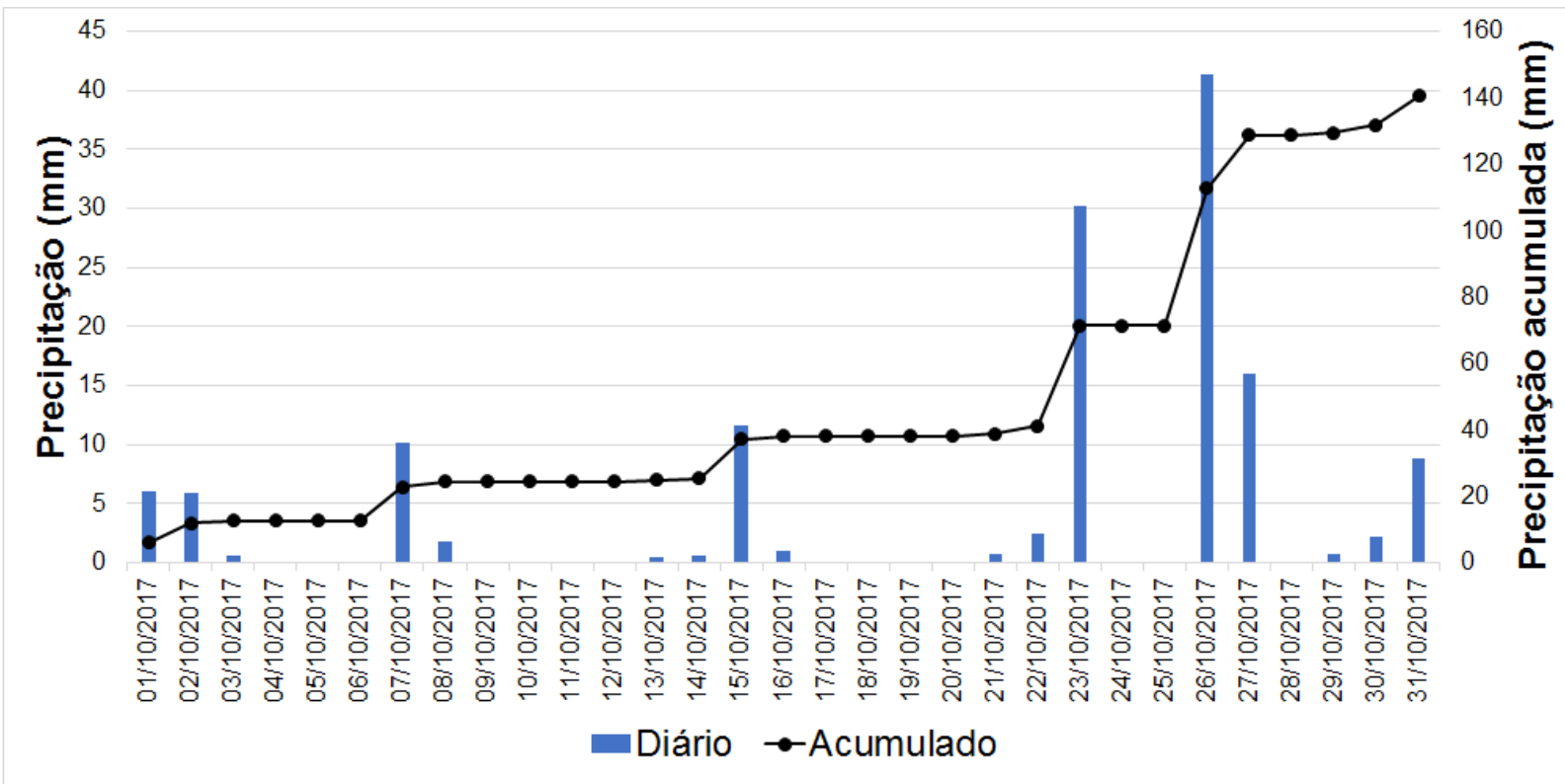




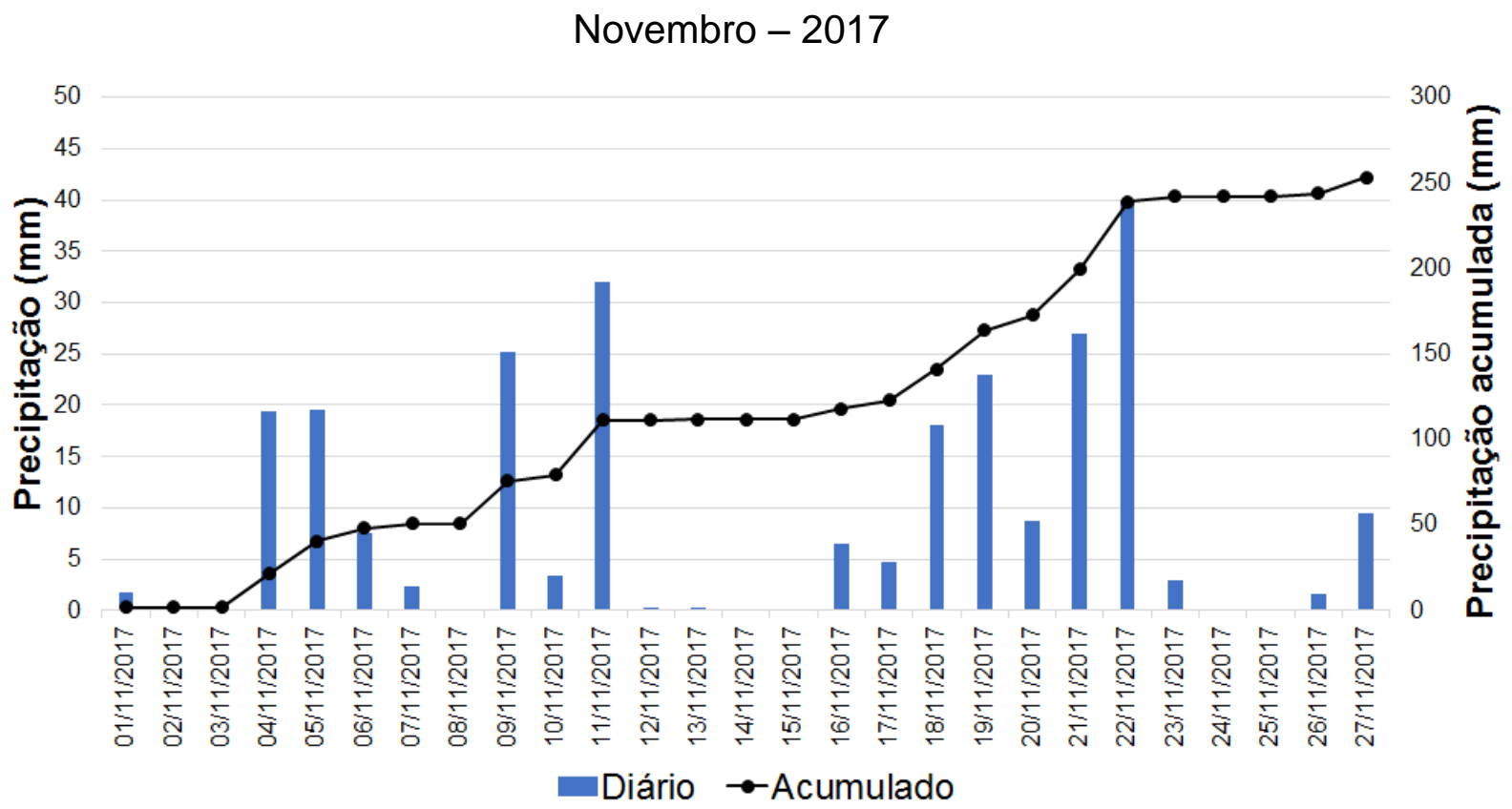

Dezembro - 2017

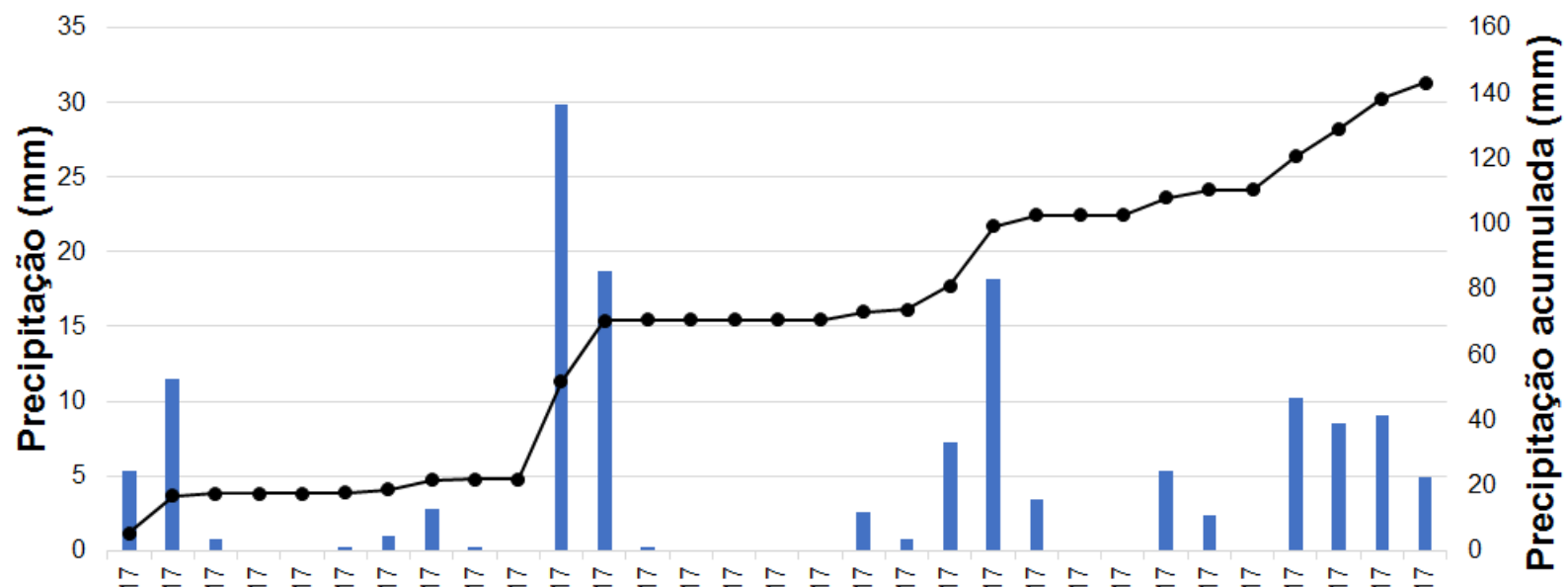

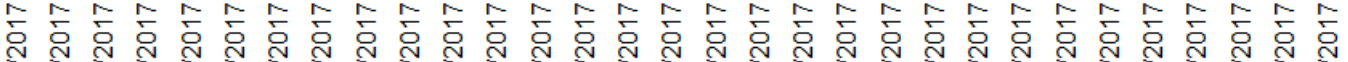
c.iv

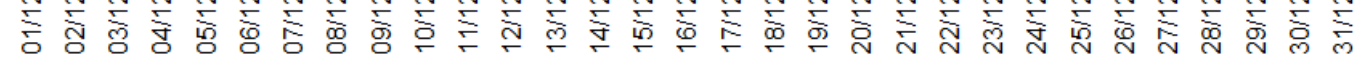
Diário - $\circ$ Acumulado 